\title{
Denmark: Detailed Assessment of Anti-Money Laundering and Combating the Financing of Terrorism
}

This Detailed Assessment of Anti-Money Laundering and Combating the Financing of Terrorism for Denmark was prepared by a staff team of the International Monetary Fund using the assessment methodology adopted by the Financial Action Task Force in February 2004 and endorsed by the Executive Board of the IMF in March 2004. The views expressed in this document are those of the staff team and do not necessarily reflect the views of the Government of Denmark or the Executive Board of the IMF.

To assist the IMF in evaluating the publication policy, reader comments are invited and may be sent by e-mail to publicationpolicy@imf.org.

Copies of this report are available to the public from

International Monetary Fund • Publication Services

700 19th Street, N.W. • Washington, D.C. 20431

Telephone: (202) 6237430 • Telefax: (202) 6237201

E-mail: publications@imf.org • Internet: http://www.imf.org

Price: $\$ 18.00$ a copy

\section{International Monetary Fund}

Washington, D.C. 

Financial Sector Assessment Program

\section{DENMARK}

DETAILED ASSESSMENT OF

ANTI-MONEY LAUNDERING

AND COMBATING THE

FINANCING OF TERRORISM

August 2006 
Contents

Page

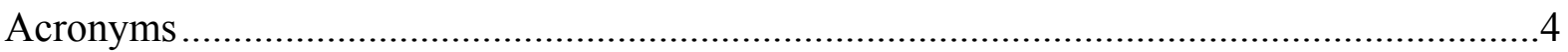

Preface — information and methodology used for the evaluation ................................6

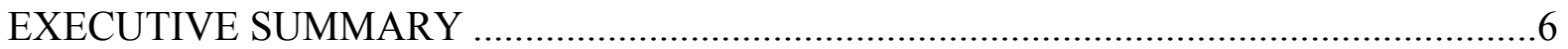

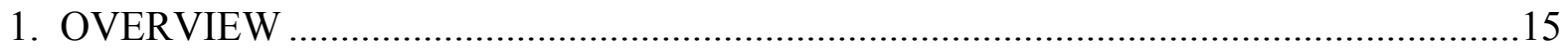

1.1 Background information on the Kingdom of Denmark ...................................... 15

1.2 General Situation of Money Laundering and Financing of Terrorism .................. 16

1.3 Overview of the Financial Sector and DNFBP .................................................. 18

1.4 Overview of commercial laws and mechanisms governing legal persons and

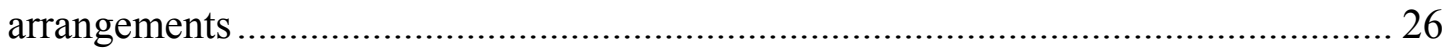

1.5 Overview of strategy to prevent money laundering and terrorist financing ........ 30

2. Legal System and Related Institutional Measures ...........................................................42

2.1 Criminalization of Money Laundering (R.1, 2 \& 32) ........................................ 42

2.2 Criminalization of terrorist financing (SR.II \& R. 32) ........................................ 53

2.3 Confiscation, freezing and seizing of proceeds of crime (R.3 \& 32) .................. 56

2.4 Freezing of funds used for terrorist financing (SR.III \& R.32) …………............ 62

2.5 The Financial Intelligence Unit (FIU) and its functions (R.26, $30 \& 32)$........... 71

2.6 Law enforcement, prosecution and other competent authorities-the framework for the investigation and prosecution of offences, and for confiscation and freezing

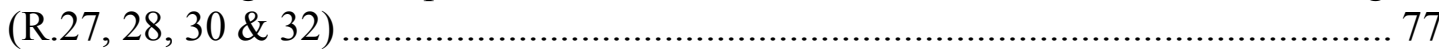

2.7 Cross Border Declaration or Disclosure (SR.IX \& R.32) .................................... 87

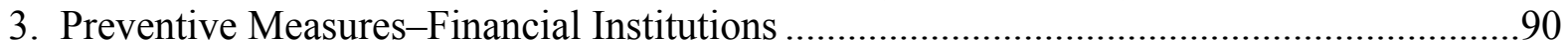

3.1 Risk of money laundering or terrorist financing ............................................... 90

3.2 Customer due diligence, including enhanced or reduced measures (R.5 to 8) ... 90

3.3 Third parties and introduced business............................................................ 107

3.4 Financial institution secrecy or confidentiality (R.4) ...................................... 108

3.5 Record keeping and wire transfer rules (R.10 \& SR.VII).................................. 110

3.6 Monitoring of transactions and relationships (R.11 \& 21) ............................... 112

3.7 Suspicious transaction reports and other reporting (R.13, 14, 19, 25 \& SR.IV) 113

3.8 Internal controls, compliance, audit and foreign branches (R.15 \& 22) ............ 122

3.9 Shell banks (R.18) ................................................................................ 124

3.10 The supervisory and oversight system-competent authorities and SROs: Role, functions, duties and powers (including sanctions) (R.23, 30, 29, 17, $32 \& 25) \ldots . .125$

3.11 Money or value transfer services (SR.VI) ………………………………..... 146

4. Preventive Measures-Designated Non-Financial Businesses and Professions .................147

4.1 Customer due diligence (R.12) (Applying R.5,6,8-11 \& 17 (only sanctions for these Recommendations.................................................................................... 147

4.2 Suspicious transaction reporting (R. 16) (applying R13-15 \& 21) ...................... 152

4.3 Regulation, supervision, and monitoring (R.24 and R.25.1) ............................ 155

4.4 Other non-financial businesses and professions-Modern secure transaction

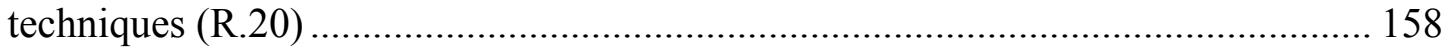

5. Legal Persons and Arrangements \& Nonprofit Organizations .........................................158 
5.1 Legal Persons-Access to beneficial ownership and control information (R.33)158

5.2 Legal Arrangements-Access to beneficial ownership and control information

(R.34) 166

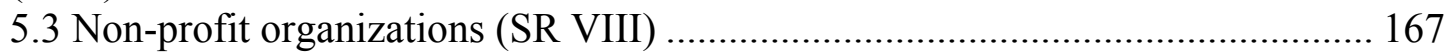

6. National and International Cooperation................................................................170

6.1 National cooperation and coordination (R.31 \& 32) (criteria 32.1 only) .......... 170

6.2 The Conventions and UN Special Resolutions (R.35 \& SR.I) ......................... 172

6.3 Mutual Legal Assistance (R.32, 36, 37, 38, SR.V).................................... 174

6.4 Extradition (R.32, 37 \& 39, \& SR.V) ......................................................... 181

6.5 Other Forms of International Cooperation (R.32, 40, \& SR.V) ...................... 185

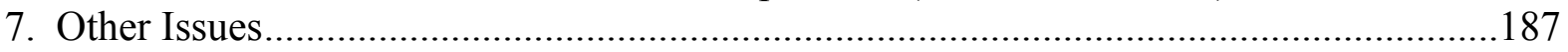

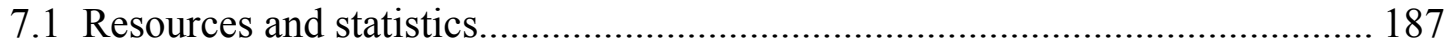

Tables

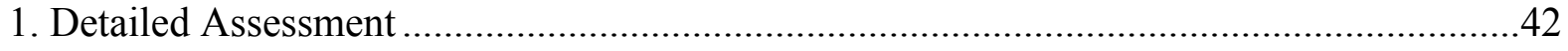

2. Ratings of Compliance with FATF Recommendations ............................................190

3: Recommended Action Plan to Improve the AML/CFT System ....................................202

Annexes

I. Details of all bodies met on the on-site mission - Ministries, other government authorities

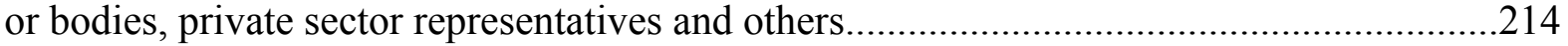

II. Copies of key laws, regulations and other measures.............................................217 
ACRONYMS

\begin{tabular}{|c|c|}
\hline AJA & The Administration of Justice Act \\
\hline $\mathrm{AML} / \mathrm{CFT}$ & $\begin{array}{l}\text { Anti-Money Laundering and Combating the Financing of } \\
\text { Terrorism }\end{array}$ \\
\hline CDD & Customer Due Diligence \\
\hline CID & Criminal Investigation Department \\
\hline CPR & Civil Registry Number \\
\hline CSP & Company Service Providers \\
\hline CVR & Central Business Register \\
\hline DACBR & The Danish Act on the Central Business Register \\
\hline DANIDA & Danish Aid Agency \\
\hline DAR & Detailed Assessment Report \\
\hline DCCA & The Commerce and Companies Agency \\
\hline DKK & Danish Kroner \\
\hline DNFBP & Designated Nonfinancial Businesses and Professions \\
\hline DPCA & The Danish Public Company Act \\
\hline $\mathrm{EC}$ & European Commission \\
\hline EEA & European Economic Area \\
\hline EEC & European Economic Community \\
\hline EEIG & The European Economic Interest Grouping \\
\hline EU & European Union \\
\hline EUR & Euro \\
\hline Extradition Act & $\begin{array}{l}\text { The Consolidated Act of August 25, 2005, No. } 833 \text { on } \\
\text { Extradition of Criminals }\end{array}$ \\
\hline FATF & Financial Action Task Force \\
\hline FBA & The Financial Business Act \\
\hline FIU & The Money Laundering Secretariat \\
\hline FSA & The Financial Supervisory Authority \\
\hline FSRB & FATF-style regional bodies \\
\hline FT & Financing of Terrorism \\
\hline GDP & Gross Domestic Product \\
\hline IMA & Insurance Mediation Act \\
\hline IMF & International Monetary Fund \\
\hline ISOBRO & The Danish Non-profit umbrella organization \\
\hline MFA & Ministry of Foreign Affairs \\
\hline ML & Money Laundering \\
\hline MLA & $\begin{array}{l}\text { The Act on Measures to Prevent Money Laundering and } \\
\text { Terrorist Financing (2006) }\end{array}$ \\
\hline MOJ & Ministry of Justice \\
\hline MOU & Memorandum of Understanding \\
\hline NAEC & National Agency for Enterprise and Construction \\
\hline $\mathrm{NAO}$ & National Audit Office \\
\hline NCCT & Noncooperative Country or Territory \\
\hline NPC & The National Commissioner of Police \\
\hline
\end{tabular}


NPO

Palermo Convention

PEP

ROSC

Terrorist Financing

Convention

SØK

SR

STR

$\mathrm{UN}$

UNSCR

VAT

Vienna Convention
Nonprofit Organization

United Nations Convention Against Transnational Organized

Crime (2000)

Politically Exposed Persons

Report on Standards and Codes

International Convention for the Suppression of the Financing of Terrorism (1999)

The Office of the Public Prosecutor for Serious Economic

Crime

Special Recommendation

Suspicious Transaction Report

United Nations

United Nations Security Council Resolution

Value added tax

United Nations Convention Against Illicit Traffic in Narcotic

Drugs and Psychotropic Substances (1988) 


\section{PREFACE-INFORMATION AND METHODOLOGY USED FOR THE EVALUATION}

1. An assessment of the anti-money laundering (AML) and combating the financing of terrorism (CFT) regime of the Kingdom of Denmark was based on the Financial Action Task Force Forty Recommendations 2003 and the Nine Special Recommendations on Terrorist Financing 2001 (FATF 40+9 Recommendations ), and was prepared using the AML/CFT Methodology 2004. The assessment considered the laws, regulations and other materials supplied by the authorities, and information obtained by the assessment team during its mission from February 27 to March 15, 2006, and subsequently. During the mission, the assessment team met with officials and representatives of all relevant government agencies and the private sector. A list of the bodies met is set out in Annex 2 to the detailed assessment report (DAR).

2. The assessment was conducted by a team of assessors composed of staff of the International Monetary Fund (IMF). The evaluation team consisted of: Richard Lalonde (team leader) and Paul Ashin of the Monetary and Financial Systems Department, and Margaret Cotter, Giuseppe Lombardo and Navin Beekarry of the Legal Department. The assessors reviewed the institutional framework, the relevant AML/CFT laws, regulations, guidelines and other requirements, and the regulatory and other systems in place to deter money laundering (ML) and the financing of terrorism (FT) through financial institutions and Designated Non-Financial Businesses and Professions (DNFBP), and examined the capacity, the implementation and the effectiveness of all these systems.

3. This report provides a summary of the AML/CFT measures in place in Denmark as of the date of the mission or immediately thereafter. It describes and analyses those measures, and provides recommendations on how certain aspects of the system could be strengthened (see Table 3). It also sets out Denmark's levels of compliance with the FATF 40+9 Recommendations (see Table 2).

\section{EXECUTIVE SUMMARY}

\section{Main findings}

1. Denmark has a solid AML/CFT framework, recently updated with a new AML/CFT law that should provide a sound basis for an effective AML/CFT regime. It has been developed in the context of the perceived and historical ML/FT threats and has effectively used moral suasion, "light-touch" supervision and enforcement, informal cooperation, and social consensus to meet that level of threat. Once fully in effect, the new AML/CFT law will create a legal framework for mainland Denmark that largely addresses the revised FATF standard and transposes the Third EU Directive on Money Laundering. However, building a fully-effective, FATF-compliant system that can protect Denmark from potential future threats is still a work in progress. Such a task would require a systematic review of policy 
and operations, including consideration of enhanced prosecution of the ML/FT offense, more pro-active supervision of financial and especially the non-financial sectors, and a reevaluation of the role and responsibilities of the Financial Intelligence Unit (FIU). Given the high competence and dedication of the professionals working within the Danish system, such changes are clearly within Denmark's grasp.

2. The new legislation, which only entered into force on March 1, 2006, sets forth a comprehensive range of requirements regarding preventive measures, but it is too early to assess how effectively the new elements will be implemented. Moreover, some key provisions - such as those regarding the enhanced customer due diligence (CDD) requirements for non face to face transactions, cross border banking relationships and Politically Exposed Persons (PEPs) — are not yet into force and some others need to be fine tuned to ensure full consistency with the FATF standards. Work is ongoing to update the legal framework in Greenland and the Faroe Islands and to extend relevant international conventions to these jurisdictions.

3. The justice and law enforcement aspects of the Danish system are characterized by a well developed legal framework for the criminalization of money laundering and terrorist financing and by advanced and flexible alternatives for the restraint and confiscation of proceeds of crime. Prosecutors and law enforcement personnel work in close cooperation, and there have been numerous convictions in recent years although with few exceptions they have involved very minor violations as receipt of stolen goods. Terrorist financing is being pursued with a couple of cases in the court system. An exemplary mutual legal assistance and extradition framework in Denmark facilitates wide ranging possibilities for assistance which is freely and effectively provided.

4. The FIU has direct access to a wide range of data. It conducts basic checks of suspicious transaction reports (STRs) against databases but virtually all STRs received are disseminated for investigation. There is considerable room for enhanced analysis of STRs. The current level of staffing and types of training may not be sufficient going forward.

5. Most Danish financial institutions appear to have well-established internal procedures for addressing AML/CFT risks, although their compliance with these requirements could be more actively supervised. The AML/CFT supervisory regimes in the DNFBP sectors-even where they have been established by prior legislation - do not appear to be robust.

6. The overall level of reporting by all sectors to the FIU is low.

7. The Kingdom of Denmark consists of three jurisdictions (Denmark, Greenland, and the Faroe Islands) each with a different set of laws relevant to AML/CFT. The new MLA has not been extended beyond Denmark proper. The Danish government is working with the Home Rule Governments of Greenland and Faroe Islands to update various aspects of their AML/CFT regimes, permit the extension of the Vienna, Palermo and Terrorist Financing conventions, and ensure full implementation of UN Security Council resolutions. The current situation has had an impact on a number of ratings. Despite the small size of these 
jurisdictions, the absence of full criminalization for terrorist financing, full implementation of the UNSCRs, and related issues relating to scope of extradition are of special concern. For preventive measures, although only the 1993 MLA is applicable to them, the relatively small size of the financial and DNFBP sectors makes this a less significant shortcoming.

\section{General Situation of Money Laundering and Financing of Terrorism}

8. Denmark is neither a major international financial center nor historically a center for significant organized crime. Biker organizations have been involved in a range of offenses from homicides and robberies to narcotics-related offenses, smuggling of goods, and various financial crimes. Dealing in narcotics and smuggling of illicit substances (including synthetic drugs as amphetamines and ecstasy) is a significant problem. Trafficking in human beings, smuggling of goods that are subject to high levels of taxation, and credit card crimes have received increased attention. Denmark is a geographically vulnerable to serving as a transit country for smuggling into Sweden and Norway. Corruption is not a significant issue.

9. Danish authorities recognize that even the relatively low level of organized crime can generate significant proceeds, but there are no reliable and accurate estimates of the amounts involved and authorities believe that in most cases, the proceeds of crime are transferred out of Denmark soon after offences occur. Major sources for proceeds are drug trafficking and economic crimes, particularly VAT and investment frauds, smuggling of goods, and violations of intellectual property rights.

10. The financing of terrorism poses some material risk within Denmark and has been the subject of a few prosecutions. Danish society contains elements (including some with fundamentalist views) which sympathize or have relations with groups or organizations involved in terrorist activities, which creates potential for recruitment and fundraising for terrorist purposes. Various contact groups and outreach efforts have been undertaken to deal with these issues.

\section{Overview of the Financial Sector and DNFBPs}

11. The Danish financial sector is deep (total assets are equal to close to five times GDP) and sophisticated. It is dominated by the banking sector. There are a large number of banks, most of them small banks. The two largest banks account for approximately 75 percent of the total assets of all banks.

12. Insurance companies, pension funds, and mutual funds account for slightly over 30 percent of financial sector assets. The five largest life insurance companies accounted for 88 percent of gross premiums. The bulk of life insurance is distributed through agency networks. By industry estimates, insurance brokers contribute 10 percent of the annual amount of new life insurance schemes. 
13. Investment companies (i.e., securities dealers and brokers), savings institutions, leasing factoring and credit card companies, as well as currency exchange agents and money transmitter agents represent a far smaller proportion of the financial sector.

14. Denmark is home to some 4800 lawyers, 2700 accountants/auditors, 2700 real estate agents, 650 dealers in precious metals and stones, and 6 casinos. Company services are generally supplied by lawyers, there is no concept of trust in Danish law and the only notaries are county court judges who do not provide services to clients. All of these businesses and professions are covered by the AML/CFT law, with the exception of precious metals and stones dealers. Instead of making the latter reporting entities, Denmark has instead chosen to outlaw all cash transactions above DKK 100,000 (EUR 13.410) ${ }^{1}$ for all forms of business.

\section{Legal Systems and Related Institutional Measures}

15. Money laundering is criminalized through a money receiving offense which covers the conduct set forth in the applicable conventions. It extends to the proceeds from any crime committed intentionally and is complemented by a separate provision that subjects grossly negligent acquisition or receipt of goods through an offense to criminal sanctions. A person's laundering of his/her own proceeds is not actionable under Denmark's ML provision unless authorities do not succeed in proceedings against the person for the predicate crime. Money laundering is punished by a fine or imprisonment of up to 18 months in the case of the basic offence and a fine or imprisonment not exceeding six years in the case of the aggravated offence. The imprisonment penalty provided by law for the basic offense is less than in many countries, and penalties imposed have been relatively low. Legal persons have criminal liability. Provisions in Greenland and the Faroe Islands do not extend to all necessary predicate crimes.

16. The criminalization of terrorism financing under provisions of the Danish Criminal Code is consistent with international standards, but Greenland and the Faroe Islands, which rely on complicity in the commission of concrete terrorist acts, have not yet enacted specific provisions criminalizing the financing of terrorist acts, terrorists and terrorist organizations. Danish authorities have pursued financing of terrorism investigations and prosecutions and a couple of cases are pending in the courts.

17. Danish law provides a very comprehensive and flexible confiscation framework with four options: a traditional conviction-based confiscation of assets derived from the offence, supplementary fines as an alternative to confiscation, confiscation provisions applicable to serious criminal acts with significant financial gain that place the onus of proving the legal origin of assets on the defendant, and preventive confiscation if necessary to prevent a criminal act or if property may be used in a criminal act. Law enforcement agencies are

\footnotetext{
${ }^{1}$ Exchange rate taken from the Financial Times as of May 9, 2006.
} 
provided with the legal means to identify, trace and seize criminal and terrorist assets. Statistics have not been sufficient to illustrate the efficiency of the system in place. Provisions in Greenland and the Faroe Islands are being updated.

18. Denmark implements the decisions of the United Nations (UN) Security Council on the freezing of terrorist assets through measures instituted by the European Union (EU) under EU Regulations $2580 / 2001$ and $881 / 2002$, as well as through national mechanisms. The implementation of these measures is coordinated by the National Agency for Enterprise and Construction, the Ministry of Foreign Affairs (MFA) and the Public Prosecutor for Serious Economic Crime (SØK). Denmark has not submitted to the relevant organizations names of any suspected terrorists for listing. The EU Regulations, which are applicable in Denmark, place no limitation on the scope of terrorist assets that can be frozen. However, Danish national mechanisms will not be employed against non-terrorism related assets of terrorists and terrorist organizations not comprised by the EU Regulations. Guidance on the practical aspects of implementing the freezing obligation should be improved, and additional legal provisions and practical arrangements are needed in Greenland and the Faroe Islands.

19. In Denmark, the FIU (known as the Money Laundering Secretariat), is an operationally independent unit within the office of the SØK, which is part of the Public Prosecution Service. The FIU has a staff of 3 prosecutors and 7 police officers. The FIU indicated that, whenever necessary, SØK provides it with supplementary staff for the performance of its functions. It also at times enlists the services of private auditors for purposes of competence and independence in respect of complex financial investigations.

20. The FIU has direct access to a wide range of data, including police databases and other public and non-public information. However, it usually requires a court order to obtain additional information from reporting entities. The FIU's analysis of STRs is limited to gathering information, largely through basic checks of an STR against databases. Virtually all STRs received are disseminated for investigation. The FIU could enhance analysis of STRs to improve the quality of the information it disseminates.

21. Considering the likely increase in numbers of STRs, the desirability of more extensive analysis of STRs, and the possibility that staff may be asked to conduct investigations for the SØK, there is some concern that the current level of staffing will not be sufficient going forward. While FIU staff receive the same training as other prosecutors and police officers assigned to the SØK, they could also benefit from more specialized training in the areas of tracing proceeds of crime, financial analysis and the financing of terrorism.

22. Denmark has an efficient, integrated law enforcement and prosecution approach, with a well staffed joint prosecutorial and law enforcement office that addresses serious economic crime at the national level and police districts that encompass both police officers and police prosecutors at the local level. The National Commissioner of Police provides a centralized supporting function and houses a national criminal investigation support center and the service responsible for national security. These bodies are adequately staffed and have legal powers to address all forms of organized and economic crime and terrorist activities. 
However, Danish authorities have only prosecuted 16 money laundering cases in the last 6 years under the provisions that carry a possible punishment of 6 years or more imprisonment. These figures appear low, even recognizing the relatively modest level of criminal activity within Denmark. Statistics are not collected or maintained in a way that allows full analysis of the nature of money laundering activity and associated predicate crime. With regards to terrorism financing, there are a couple of cases pending but no convictions yet.

23. Denmark has established a system of declaration of cash and similar assets being transported across its borders. The Customs and Tax authority implements the system in conjunction with the police, which together have the necessary powers for an effective system. All declarations as well as information on non- or falsely declared currency and other bearer negotiable instruments are sent to the FIU. The small number of declarations would suggest a low level of compliance. Moreover, all monies that have been detained for failure to comply with the obligation have been returned and no sanctions have been imposed.

\section{Preventive measures - Financial Institutions}

24. The new Act on Measures to Prevent Money Laundering and Terrorist Financing (MLA), which entered into force on March 1, 2006, was adopted with a view to implementing the third EU AML Directive and the revised FATF Recommendations. While the coverage of the previous act was already quite comprehensive, encompassing both financial and non financial sectors as defined by the FATF, the new MLA, inter alia, addresses areas such as beneficial ownership and enhanced and simplified CDD and introduces elements of a risk based approach.

25. The new MLA sets forth a comprehensive range of requirements regarding preventive measures. However, the provisions regarding enhanced CDD requirements for non face to face transactions, cross border banking relationships, and PEPs, as well as the provisions on shell banks, the obligation to investigate the purpose unusually or large transactions and the obligation to monitor the customer relationship on a regular basis will only come into force on January 1, 2007. The act is not yet applicable in Greenland and in the Faroe Islands. The previous 1993 MLA — which, for the financial sector, provided basic requirements for identification, record keeping and reporting of suspicious transaction for ML—was extended to Greenland in 1996 and to the Faroe Islands in 1997.

26. Although Denmark has no explicit provision or regulation prohibiting the existence of anonymous accounts, the customer identification requirements of the MLA and tax legislation make them effectively impossible.

27. Some exemptions to the CDD requirements - where a lawyer holds a client's funds in an individual account or in the case of some non face to face transactions occurring in the insurance sector - do not appear to be justified on the basis of a risk assessment and, therefore, do not conform with the FATF standard. 
28. The AML requirements set forth in the new law appear to be generally in line with the FATF standards. In the area of CDD some requirements, however, need to be adjusted to come into full conformity with the FATF standards. In particular:

- there is no requirement to verify/identify that an individual purporting to act on behalf of a legal person or arrangement is so authorized;

- the identification requirements for occasional transactions that are wire transfers apply only in the case of wire transfers of 15.000 EUR or more;

- there is no obligation for institutions relying on third parties to take adequate steps to satisfy themselves that copies of the identification data and other documentation relevant for CDD purposes will be made available from the third party upon request without delay.

29. Not all obligations set forth in the MLA are covered by sanctions and no sanctions have ever been applied under the previous act. In the absence of pre-set fines or range of fines and with no history of imposed fines it is not possible to conclude that sanctions are effective, proportionate or dissuasive. There is a limited range of administrative sanctions to enforce compliance and relatively few actions have been taken.

30. Suspicious transaction reporting from Danish financial institutions has been modest, given the size of the financial sector. It has also been largely concentrated in bureaux de change and commercial banks. Moreover, since the Denmark was assessed by FATF in 1997, there has been little progress in reporting by the insurance and securities sectors, with virtually no STRs reported. The reporting regime is thus not fully effective.

31. The new MLA also introduces a misalignment between the criminalization of ML, which is based on an all crimes approach, and the reporting requirement which applies only when a suspicion refers to a predicate crime punishable by more than one year's imprisonment. This change from the previous regime creates unnecessary confusion for reporting entities. The reporting requirement for Greenland and the Faroe Islands, based as it is on the 1993 MLA, does not meet FATF standards - especially as it does not include terrorist financing.

32. Bank licensing requirements preclude the establishment of shell banks in Denmark. Moreover, the MLA prohibits banks, mortgage-credit institutions and electronic money institutions from entering into or continuing a correspondent banking relationship with a shell bank. They are also required to take reasonable measures to avoid a connection with a credit institution, which is known to permit shell banks to use its accounts. However, the latter two measures will only take effect on January 1, 2007.

33. The FSA is responsible for regulating and supervising all financial institutions, except undertakings and persons that commercially carry out activities involving currency exchange or transfer of money and other assets (money remitters and exchange bureaus), which are regulated and supervised by the DCCA. Both supervisory authorities are appropriately 
structured and enjoy sufficient operational independence. Regulation-making authority with respect to $\mathrm{AML} / \mathrm{CFT}$ is limited.

34. The major focus of the FSA's AML/CFT supervision has been on reviewing internal guidelines of financial institutions with little attention paid to assessing the implementation of the guidelines. In the period prior to the assessment AML/CFT inspections of large banks were infrequent and not comprehensive. Since then the FSA has completed on site inspections of the largest banks. The DCCA's inspections are not comprehensive. The resources allocated to inspections for AML/CFT by both agencies need to be reviewed and staff training expanded.

\section{Preventive Measures - Designated Non-Financial Businesses and Professions}

35. The key weaknesses in the AML/CFT regime for DNFBPs concern implementation and especially supervision. Denmark's CDD and STR requirements for DNFBPs, while sharing the general shortcomings detailed above, are relatively robust on paper. However, the recent passage of the legislation leaves no base for judging how effective this regime will be in practice and the low level of reporting from DNFBPs such as lawyers, who were covered under previous legislation, raises significant questions. The effectiveness of the ban on cash transactions as a mechanism for eliminating ML/FT risks should be reviewed and evaluated in due course.

36. The Danish AML/CFT supervisory regimes for DNFBPs are largely untested and the limited track record is not encouraging. The Bar and Law Association does not conduct examinations of the AML/CFT practices of its members, the casino inspectors serve primarily as a reporting conduit, and the DCCA is taking on a significantly expanded set of functions which may tax the resources allocated for it. There are grounds for optimism that the DCCA can build on its existing supervisory role for accountants and its role in company formation to effectively and efficiently oversee accountants and CSPs. However, the supervision of the real estate profession may pose greater challenges.

\section{Legal Persons and Arrangements}

37. Danish legislation allows for the formation of several forms of legal persons. In general, legal persons have full legal capacity. However, in some cases the entity is not recognized as a legal person until it has been registered..

38. Businesses in Denmark are registered in different registers based on the nature of the entity. All business are also registered in the Central Business Register (CVR). At the time of the assessment there were approximately 580,000 businesses registered in the CVR.

39. The data entered in the CVR are available to the authorities and the public, including online. With one exception, no information on the beneficial owner of an entity is available in the CVR. For public and private companies (A/S and ApS), information about beneficial ownership is available in some circumstances in private registers such as company books. 
The authorities rely on the investigative powers and on inspection powers to obtain the information on beneficial ownership. However, the information that can be obtained may not be up to date; in the case of foreign companies registered in Denmark beneficial ownership information is not available.

40. Public companies can issue bearer shares up to their entire capital. In such instances information on beneficial ownership is available only for shareholders that have holdings above a designated threshold.

\section{Nonprofit Organizations}

41. The Danish Nonprofit Organization (NPO) sector is numerous, diverse, and mainly "regulated" through its relations with the tax authorities. It is estimated that there are some 85,000 NPOs, either in the form of associations or foundations. About 66,000 of those have registered with the authorities to obtain a CVR number, 17,000 of the foundations have to file annual tax returns, and 836 of the largest have applied for and received tax privileges. Registration requires supplying basic identification information to the authorities and tax returns and tax privileges involve progressively greater levels of financial disclosure. The bulk of NPO income - especially those NPOs that work internationally-comes from grants from the Danish Government, the EU, or other international organizations, which are very closely monitored.

42. The Danish authorities have only conducted an informal review of their NPO system, and should use the recent elaboration of the international standard in the Interpretive Note to SR VIII as an opportunity to examine the problem more comprehensively and formally. This would also allow them to increase their outreach to the NPO sector on issues associated with terrorist financing.

\section{National and International Co-operation}

43. There is informal cooperation between the FIU and other domestic agencies involved in the AML/CFT effort but there is no one agency or vehicle for coordinating national AML/CFT policies and practices. A platform for inter-agency policy level review of AML/CFT initiatives should be established and the FIU and supervisory agencies should engage in closer and more regular coordination of efforts. The overall effectiveness of criminal and preventive measures would be enhanced with more intensive regular reviews of the strengths and weaknesses of the systems, and aided by more comprehensive gathering of meaningful statistics.

44. Denmark is a party to all international relevant AML/CFT instruments but the instruments have not yet been extended to Greenland or the Faroe Islands nor have the UN Security Council resolutions been fully implemented in those two jurisdictions. Denmark has an exemplary mutual legal assistance framework with an ability to provide assistance through bilateral and multilateral international cooperation agreements as well as in the absence of such agreements. Extradition may occur through a series of instruments. The European arrest 
warrant has been implemented. Greenland and the Faroe Islands have a more circumscribed ability to provide mutual legal assistance and extradition cooperation. This is being addressed through a Danish government initiative to ensure full implementation of relevant conventions and UN resolutions in the Home Rule legislation of Greenland and the Faroe Islands.

45. In practice, Denmark seems to be an active and cooperative international criminal justice partner. The FIU, which belongs to the Egmont Group, has adequate powers for international cooperation and can legally provide spontaneous information to other countries. The FSA is a party to a number of multilateral and bilateral arrangements for international cooperation which appear to be operating in a satisfactory manner.

\section{OVERVIEW}

\subsection{Background information on the Kingdom of Denmark}

46. The Kingdom of Denmark consists of Denmark, Greenland, and the Faroe Islands. Denmark is in northern Europe and borders on the Baltic and North seas and Germany. Its capital is Copenhagen, which is situated on Zealand. It is about 43,000 square kilometers and has a population of about 5.4 million, of whom about 1.8 million live in the Copenhagen metropolitan area. Greenland, most of which is covered by the polar ice cap, is approximately 2.175 million square kilometers. It has approximately 57,000 inhabitants and its capital is Nuuk. The Faroe Islands consist of 18 islands with a total area of about 1400 square kilometers. The islands have approximately 48,000 inhabitants and the capital is Torshavn. Greenland and the Faroe Islands are self-governing overseas administrative divisions of the Kingdom of Denmark.

47. The Kingdom of Denmark was first organized as a unified state in the tenth century and it became a constitutional monarchy in 1849. Queen Margrethe II is the sovereign of Denmark. There is a parliamentary democratic system of governance. The sovereign and the Parliament make up the legislature. The Parliament has 179 members who are elected for a maximum term of four years and are eligible for re-election. Both Greenland and the Faroe Islands are self-governing and are represented in the Danish parliament by two members.

48. The legislative branch in Denmark consists of a 179-seat unicameral Parliament called the Folketinget whose members are directly elected by popular vote to serve four-year terms. Of the 179 seats, two members are from Greenland and two are from the Faroe Islands. In addition, Greenland has a unicameral Parliament, the Landstinget, which has 31 seats with members elected by popular vote to serve four-year terms, and similarly, the Faroese Parliament or Logting has 32 seats with members elected by popular vote for fouryear terms. The head of the government in each jurisdiction is the Prime Minister who appoints the cabinet. Since 1973, Denmark has been a member of the EU. Neither Greenland nor the Faroe Islands are members. 
49. For Denmark, the Folketinget has exclusive jurisdiction to enact criminal laws. The government presents bills to the Parliament including "explanatory notes." Explanatory notes are recognized as a source of proper interpretation of the law and are used widely by the Danish courts when interpreting the law. A growing proportion of legislation operative in Denmark is enacted by the EU. Some of these laws apply directly, without prior sanction by the Folketinget, while others must be implemented in Danish legislation before they can take effect.

50. Denmark has an independent judiciary. Judges are appointed by the Queen upon recommendation from the Minister of Justice, who is advised by the Judicial Appointments Council. The Constitution guarantees judges independence from the government and the Parliament. A judge can be removed from office only by order of the Special Court of Indictment and Revision. There are 82 County Courts, the Maritime and Commercial Court of Copenhagen, two high courts and the Supreme Court. On the Faroe Islands, there is the County Court for the Faroe Islands and in Greenland there is a High Court and 18 regional Magistrates Courts. Denmark has no constitutional court. Ordinary courts may determine whether a law is in accordance with the Constitution, to which all other laws are subordinate, and the matter may be heard in the last instance by the Supreme Court.

51. Denmark is a modern market economy and its standard of living is reputed to be among the highest in the world. As in most other highly developed economies, services contribute the biggest share of total GDP. Industry contributes the second biggest share. Denmark contributes about one percent of its gross national income to foreign aid. Denmark is a net exporter of energy and food and has a balance of payments of surplus.

52. Greenland, the world's largest island, is about 81 percent ice-capped. With the closure of the last of Greenland's lead and zinc mines in 1989, Greenland's economy is dependant upon its fishing industry and Danish grants. Grants from Denmark and EU fisheries payments make up a significant part of the revenues for Greenland's home rule government. The Faroe Islands also depend upon fisheries and related exports, and receive a subsidy from Denmark.

\subsection{General Situation of Money Laundering and Financing of Terrorism}

\section{a. Organized Crime and Money Laundering}

53. Danish authorities indicate there is no history of significant organized crime in Denmark. With relatively low levels of crime domestically, Danish law enforcement indicate they remain vigilant for changes in criminal patterns internally and for infiltrations of proceeds of international criminal activity into the Danish financial or other institutions.

54. Denmark is not a major financial center and, although authorities do not believe Denmark is very often viewed as a particularly attractive place for criminals to place criminal proceeds, there have been some instances of placement of proceeds in banks in situations where neither the victim nor the perpetrator resided in Denmark. Corruption is not 
a major problem in Denmark. The 2004 Corruption Perceptions Index issued by Transparency International ranks Denmark as the third least corrupt country in the world.

55. The National Commissioner of the Police's 2004 status report to Europol on organized crime noted a modest level of organized crime that originates in Denmark, with the presence of biker organizations as the Hell's Angels and Bandidos as a major cause of concern. Persons associated with biker groups have been known to have involvement in criminal activity that ranges from crimes of violence, as homicide and robbery, to nonviolent activity such as narcotics related offenses, smuggling of goods and various forms of financial crime. Although there is only very limited production of narcotics in Denmark, dealing in narcotics and smuggling of illicit substances (cannabis, heroin, cocaine and synthetic drugs, and particularly amphetamines and ecstasy) is reported as a significant problem. Trafficking in human beings is also a crime that is receiving increased attention as is the smuggling of goods subject to high levels of taxation. Because of its geographical location, Denmark is vulnerable to serving as a transit country for the smuggling of human beings and narcotics into Sweden and Norway.

56. Denmark's report to Europol on its perceptions of the level of organized crime both for 2004 and for previous years is that it is relatively modest. In addition, there is no indication that organized crime has infiltrated law enforcement, nor that organized crime is able to influence political circles or public administration. Although Danish authorities believe the proceeds generated in connection with the relatively low levels of organized crime that do exist are significant, they do not have an estimate of the amounts involved. Credit card crime is viewed as a growing problem in particular the abuse of credit card information that is often acquired through use of the Internet.

57. As to the general situation of money laundering, Danish authorities report drug crimes and various types of economic crimes, particularly VAT and investment frauds, smuggling, and violations of intellectual property rights as major sources for proceeds. The Danish authorities believe that most significant proceeds are transferred out of Denmark soon after offences occur. In drug trafficking cases, the formal banking system, couriers and alternative remittances systems are employed for this purpose. In the case of economic crimes, criminals also use the formal banking system to transfer funds for bogus investments or to make what may appear to be normal business payments. In VAT-fraud matters, for instance, a company may transfer all its assets elsewhere, indicating the transfer of funds is a prepayment for goods. In investment fraud matters, investors may be asked to transfer funds into accounts in other jurisdictions to complete the investment.

58. Denmark recognizes its general vulnerability to international terrorism as being similar to that of other countries in Western Europe and heightened in the wake of 11 September and the bombings of transportation systems in other European jurisdictions. The Danish Security Intelligence Service has recognized that there are persons and circles within Denmark that sympathize with or have relations with groups or organizations involved in terrorist activities, and that there are areas of society where there are fundamentalist views, 
and potential for growth and recruitment for terrorist activities. There are various contact groups and outreach efforts to deal with these issues. In addition, authorities have undertaken criminal investigations and prosecutions that deal with the financing of terrorism including investigations of NPOs and persons who have allegedly collected or disseminated monies to terrorist organizations.

\subsection{Overview of the Financial Sector and DNFBP}

\section{a. Overview of Denmark's financial sector}

59. The Danish financial sector is deep (total assets are equal to close to five times GDP) and sophisticated. Since the deregulation of the 1970-80s, the business areas in the financial sector have overlapped. While it is still prohibited to carry on some financial activities in one and the same company (for example, commercial banking and insurance activities), it is possible to set up holding companies and inter company ownership among financial institutions. As a result, there have been a number of mergers, group formations, but also some break-ups in the last two decades. The structure of the Danish financial system is shown in Table 1.

60. The two largest banks account for approximately 75 percent of the total assets of all banks. Banks provide a range of deposit-taking and credit services, as well as a broad range of other financial services.

61. The Danish financial sector is characterized by a large number of banks, most of them small banks. At the end of 2004, total assets of credit institutions were around 325 percent of GDP. Currently, there are 184 credit institutions registered in Denmark, of which 176 are commercial banks, 8 are mortgage banks, and one is a specialized bank. Commercial banks include savings banks and cooperative banks, which are governed by the Financial Business Act. There are many small banks in Denmark. Many use common IT service centers, which they may own. The two largest banking groups_-Danske Bank and Nordea Danmarkaccount for more than 50 percent of commercial bank lending. ${ }^{2}$ The five largest banking groups account for about 80 percent of total loans. There is thus a substantial concentration in spite of the high number of institutions. Comparisons of some of the ratios of commercial banks with banks in other countries warrant some caution, since the bulk of best secured housing finance in Denmark is conducted by the specialized mortgage credit banks, several of whom, however, are linked to commercial banks. In 2004, the total assets of banks were 340,607 million EUR.

62. Danish mortgage financing has been governed by special legislation, which allows specialized mortgage credit banks to securitize mortgages. With total assets close to

\footnotetext{
2 Danske Bank's Danish operations form the hub of a predominantly Scandinavian group, with solid market shares in Sweden and Norway. Nordea Danmark is the Danish segment of the pan-Nordic Nordea Group, which straddles the region and includes four well-established banks in Finland, Sweden, Norway, and Denmark.
} 
150 percent of the GDP, the Danish mortgage banks are only slightly smaller than the Danish commercial banks. The mortgage banking sector is dominated by two institutions-Nykredit and Realkredit Danmark - which accounted for more than 70 percent of new gross lending as of September 2004. Nykredit owns a bank. Realkredit Danmark is part of Den Danske banking group - the largest Danish bank. The total assets of the mortgage credit institutions were 285,328 million EUR.

63. Insurance companies, pension funds and mutual funds account for slightly over 30 percent of financial sector assets, equivalent to around 160 percent of GDP. Compared to other countries, Denmark has a well-developed and mature insurance industry with some 162 insurance companies and 77 pension funds offering a broad range of high-quality insurance and pension products to personal and corporate customers alike. In 2004, the five largest life insurance companies accounted for 88 percent of gross premiums. As in many other countries with a matured financial sector, the value of assets managed by the Danish mutual funds has been growing particularly rapidly in recent years, albeit from a low base.

64. Since 1 January 2000, insurance intermediaries have been regulated by the Insurance Mediation Act (IMA). The FSA licenses the brokers. The brokers are also registered in a public register, which is accessible on the FSA web-site. As of 1 January 2006, 11 life insurance brokers were licensed to provide life insurance mediation and 172 insurance brokers had a license to offer both life and non-life insurance mediation. The insurance mediation organizations estimate that life insurance brokers contribute 10 percent of the annual amount of new life insurance schemes.

65. In Denmark securities dealers and brokers are covered by the term "investment companies". Danish investment companies vary in size from small single proprietorship to large companies. Of the 32 investment companies licensed in Denmark, 14 hold the large license that allows them to trade for their own account (capital requirement is one million euros.) and 18 hold the small license (capital requirement is 300,000 euros). The accumulated capital requirement for the 32 investment companies is approx. DKK 252 million (EUR 33,8 million). 10 of the licensed companies also hold a license to provide services internationally. 959 foreign investment companies have licenses in their home countries to carry out activities in Denmark. Five of these have established a branch in Denmark. 
Structure of the Financial Sector, 2004

\begin{tabular}{|c|c|c|c|c|}
\hline & $\begin{array}{l}\text { Number of } \\
\text { institutions }\end{array}$ & $\begin{array}{l}\text { Total assets } \\
\text { (EUR million) }\end{array}$ & $\begin{array}{l}\text { Authorization/ } \\
\text { Registration and } \\
\text { supervision }\end{array}$ & $\begin{array}{l}\text { Supervision } \\
\text { AML/CFT }\end{array}$ \\
\hline Commercial banks & 176 & 340,607 & $\mathrm{FSA}^{1 /}$ & $\overline{F S A}$ \\
\hline Mortgage banks & 8 & 285,328 & FSA & FSA \\
\hline Investment companies & 32 & 175 & FSA & FSA \\
\hline Collective investment associations & 105 & 77,060 & FSA & FSA \\
\hline $\begin{array}{l}\text { Life insurance companies and } \\
\text { occupational pension funds }\end{array}$ & 67 & 154,590 & FSA & FSA \\
\hline Company pension funds & 44 & 5,274 & FSA & FSA \\
\hline Insurance brokers & 183 & & FSA & $\mathrm{FSA}^{21}$ \\
\hline E-money & $1^{3 / 7}$ & & FSA & FSA \\
\hline Savings institutions & 14 & 960 & FSA & FSA \\
\hline Foreign exchange & 100 & & $\mathrm{DCCA}^{4 / 21}$ & $\mathrm{DCCA}^{2 t}$ \\
\hline Money transmitters & 120 & & DCCA" & DCCA \\
\hline Leasing- and factoring & est. 60 & N/A & FSA & $\mathrm{FSA}^{2 I}$ \\
\hline Credit cards etc. & est. 158 & N/A & FSA & $\mathrm{FSA}^{21}$ \\
\hline Postal services ${ }^{5 /}$ & $825^{67}$ & $\mathrm{~N} / \mathrm{A}$ & $\mathrm{FSA}^{5 /}$ & FSA \\
\hline
\end{tabular}

1/ The Danish Supervisory Authority

2/ As of March 1, 2006

$3 /$ Under liquidation.

4/ The Danish Commerce and Companies Agency

5/ PostDanmark provides financial services on behalf of Danke Bank which is regulated and supervised by the FSA.

6/ Number of branches

7/ As of January 1, 2004. Between 2002 and 2004, registration of money transmitters was carried out by the Public Prosecutor for Serious Economic Crime.

\begin{tabular}{|l|c|l|c|c|}
\hline & $\begin{array}{l}\text { Number of DK } \\
\text { branches } \\
\text { abroad }\end{array}$ & $\begin{array}{l}\text { Number of DK } \\
\text { subsidiaries } \\
\text { abroad }\end{array}$ & $\begin{array}{l}\text { Foreign branches } \\
\text { in DK }\end{array}$ & $\begin{array}{l}\text { Supervision of } \\
\text { foreign } \\
\text { branches in DK }\end{array}$ \\
\hline Commercial banks & 58 & 9 & 24 & Yes \\
\hline Mortgage banks & -- & 2 & -- & N/A \\
\hline Life Insurance Companies & 2 & -- & 5 & Yes $^{21}$ \\
\hline Investment companies & 1 & -- & 5 & Yes $^{21}$ \\
\hline
\end{tabular}

1/ For AML/CFT only, since 2005.

2/ For AML/CFT only, as of March 1, 2006.

66. The following financial institutions are covered by the MLA:

1) Banks.

2) Mortgage-credit institutions.

3) Investment companies.

4) Investment management companies.

5) Life insurance companies and lateral pension funds (nationwide occupational pension funds).

6) Savings undertakings.

7) Electronic money institutions.

8) Insurance brokers, when they act in respect of life assurance or other 
investment-related insurance activities.

9) Foreign undertakings' branches in Denmark, carry out activities under nos. 1-8.

10) Investment associations and special-purpose associations, collective investment schemes, restricted associations, innovation associations and hedge associations.

11) Undertakings and persons that commercially carry out activities involving currency exchange or transfer of money and other assets.

12) Other undertakings and persons that commercially carry out one or more of the following activities:

a) Acceptance of deposits and other repayable funds.

b) Lending, including

i) consumer credit,

ii) mortgage-credit loans,

iii) factoring and discounting,

iv) financing of commercial transactions (including forfeiting).

c) Financial leasing.

d) Payment services (money transmission services).

e) Issue and administration of means of payment (e.g. credit cards, travellers' cheques, and bankers' drafts).

f) Guarantees and collateralisation.

g) Trading for own account or for account of customers in:

i) money market instruments (cheques, bills, certificates of deposit, etc.)

ii) the foreign exchange market

iii) financial futures and options

iv) currency and interest rate instruments

v) securities.

h) Participation in issuing securities and provision of related services.

i) Advice to undertakings on capital structure, industrial strategy and related questions and advice, and services relating to mergers and the acquisition of undertakings.

j) Money broking.

k) Portfolio management and advice.

1) Safekeeping and administration of securities.

m) Safe custody services.

13) Lawyers, when they

a) participate by providing assistance in the planning or execution of transactions for their clients concerning

i) purchase and sale of real property or undertakings,

ii)managing their clients' money, securities, or other assets,

iii) opening or managing bank accounts, savings accounts, or securities accounts,

iv) raising the necessary capital for establishment, operation, or management of undertakings,

v) establishing, operating, or managing undertakings,

vi) providing other business advice, or 
b) on behalf of their client and at said client's expense carry out a financial transaction or a transaction concerning real property.

14) State-authorised public accountants and registered public accountants.

15) Authorised estate agents.

16) Undertakings and persons that otherwise commercially supply the same services as the groups of persons mentioned in nos. 13-15, including tax advisors and external book-keepers.

17) Providers of services for undertakings, cf. section 3 , no. 5 .

18) Danmarks Nationalbank (Denmark's central bank), insofar as it exercises activities corresponding to those of the institutions specified in no.1.

67. The following table sets out the types of financial institutions that can engage in the financial activities that are within the definition of "financial institutions" in the FATF 40+9. 


\begin{tabular}{|c|c|c|}
\hline \multicolumn{3}{|c|}{ FINANCIAL ACTIVITY BY TYPE OF FINANCIAL INSTITUTION } \\
\hline $\begin{array}{c}\text { Type of Financial Activity } \\
\text { (See the Glossary of the } 40 \text { Recommendations) }\end{array}$ & $\begin{array}{l}\text { Type of Financial Institution that } \\
\text { Performs this Activity }\end{array}$ & AML/CFT Supervision \\
\hline $\begin{array}{l}\text { 1. Acceptance of deposits and other repayable funds } \\
\text { from the public (including private banking) }\end{array}$ & 1. Banks & 1. FSA \\
\hline $\begin{array}{l}\text { 2. Lending (including consumer credit; mortgage } \\
\text { credit; factoring, with or without recourse; and } \\
\text { finance of commercial transactions (including } \\
\text { forfeiting)) }\end{array}$ & $\begin{array}{l}\text { 1. Banks } \\
\text { 2. Credit cards companies } \\
\text { 3. Factoring and finance/consumer } \\
\text { credit companies }\end{array}$ & $\begin{array}{l}\text { 1. FSA } \\
\text { 2. FSA* } \\
\text { 3. FSA }\end{array}$ \\
\hline $\begin{array}{l}\text { 3. Financial leasing (other than financial leasing } \\
\text { arrangements in relation to consumer products) }\end{array}$ & $\begin{array}{l}\text { 1. Banks } \\
\text { 2. Leasing companies }\end{array}$ & $\begin{array}{l}\text { 1. FSA } \\
\text { 2. FSA }\end{array}$ \\
\hline $\begin{array}{l}\text { 4. The transfer of money or value (including financial } \\
\text { activity in both the formal or informal sector } \\
\text { (e.g. alternative remittance activity), but not including } \\
\text { any natural or legal person that provides financial } \\
\text { institutions solely with message or other support } \\
\text { systems for transmitting funds) }\end{array}$ & $\begin{array}{l}\text { 1. Banks } \\
\text { 2. Money remitters }\end{array}$ & $\begin{array}{l}\text { 1. FSA } \\
\text { 2. } \mathrm{DCCA}^{* *}\end{array}$ \\
\hline $\begin{array}{l}\text { 5. Issuing and managing means of payment } \\
\text { (e.g. credit and debit cards, cheques, traveller's } \\
\text { cheques, money orders and bankers' drafts, } \\
\text { electronic money) }\end{array}$ & $\begin{array}{l}\text { 1. Banks } \\
\text { 2. Credit cards companies } \\
\text { 3. Electronic money institutions }\end{array}$ & $\begin{array}{l}\text { 1. FSA } \\
\text { 2. FSA* } \\
\text { 3. FSA }\end{array}$ \\
\hline 6. Financial guarantees and commitments & 1. Banks & 1. FSA \\
\hline $\begin{array}{l}\text { 7. Trading in: } \\
\text { (a) money market instruments (cheques, bills, CDs, } \\
\text { derivatives etc.); } \\
\text { (b) foreign exchange; } \\
\text { (c) exchange, interest rate and index instruments; } \\
\text { (d) transferable securities; } \\
\text { (e) commodity futures trading }\end{array}$ & $\begin{array}{l}\text { 1. Banks } \\
\text { 2. Investment companies }\end{array}$ & $\begin{array}{l}\text { 1. FSA } \\
\text { 2. FSA }\end{array}$ \\
\hline $\begin{array}{l}\text { 8. Participation in securities issues and the provision } \\
\text { of financial services related to such issues }\end{array}$ & $\begin{array}{l}\text { 1. Banks } \\
\text { 2. Investment companies }\end{array}$ & $\begin{array}{l}\text { 1. FSA } \\
\text { 2. FSA }\end{array}$ \\
\hline 9. Individual and collective portfolio management & $\begin{array}{l}\text { 1. Banks } \\
\text { 2. Investment companies } \\
\text { 3. Investment associations }\end{array}$ & $\begin{array}{l}\text { 1. FSA } \\
\text { 2. FSA } \\
\text { 3. FSA }\end{array}$ \\
\hline $\begin{array}{l}\text { 10. Safekeeping and administration of cash or liquid } \\
\text { securities on behalf of other persons }\end{array}$ & $\begin{array}{l}\text { 1. Banks } \\
\text { 2. Investment companies } \\
\text { 3. Investment management } \\
\text { companies. }\end{array}$ & $\begin{array}{l}\text { 1. FSA } \\
\text { 2. FSA } \\
\text { 3. FSA }\end{array}$ \\
\hline $\begin{array}{l}\text { 11. Otherwise investing, administering or managing } \\
\text { funds or money on behalf of other persons }\end{array}$ & 1. Banks & 1. FSA \\
\hline $\begin{array}{l}\text { 12. Underwriting and placement of life insurance and } \\
\text { other investment related insurance (including } \\
\text { insurance undertakings and to insurance } \\
\text { intermediaries (agents and brokers)) }\end{array}$ & $\begin{array}{l}\text { 1. Life insurance companies } \\
\text { 2. Lateral pension funds } \\
\text { 3. Life insurance agents and } \\
\text { brokers }\end{array}$ & $\begin{array}{l}\text { 1. FSA } \\
\text { 2. FSA } \\
\text { 3. FSA* }\end{array}$ \\
\hline 13. Money and currency changing & $\begin{array}{l}\text { 1. Banks } \\
\text { 2. Foreign exchange offices }\end{array}$ & $\begin{array}{l}\text { 1. FSA } \\
\text { 2. DCCA* }\end{array}$ \\
\hline
\end{tabular}

* As of March 1, 2006

** As of January 1, 2004 


\section{b. Overview of designated non-financial businesses and professions (DNFBPs)}

Casinos

68. Denmark has 6 gambling casinos that are regulated by the Gambling Casino Act and the Order on Gambling Casinos. They are located in 6 different municipalities. In 2005, the gross income from Casinos was DKK 370 million (EUR 40,6 million) and that from gaming machines outside of casinos was DKK 2.085 billion (EUR 279,6 million).

Real estate agents

69. Denmark has 2,758 registered real estate agents. They are all registered in "The Real Estate Register" (Ejendomsmæglerregistret, www.cvr.dk) and licensed by the Danish Commerce and Companies Agency (DCCA) according to the Act on Selling and Buying Property. There is no government agency charged with the ongoing supervising of real estate agents' compliance with non AML/CFT laws and regulations.

70. Real estate agents are covered by the MLA. According to the 2006 MLA the DCCA will be the competent authority for AML/CFT supervision.

71. In Denmark lawyers are also permitted to act as real estate agents and 281 lawyers have been so registered and licensed.

Dealers in precious metals and stones

72. According to the CVR (CVR-registret, www.cvr.dk) Denmark has 654 dealers in precious metals and stones in total. There is no government agency charged with the ongoing supervising of their compliance with Danish laws and regulations.

Lawyers

73. At the time of the mission, there were approximately 4,800 lawyers practicing in Denmark. There is no distinction between barristers and solicitors in Danish law; the only title for lawyer is advokat. According to Section 119 of the Administration of Justice Act, permission to practice as a lawyer is granted by the Minister of Justice. According to Section 131 in the Administration of Justice Act (AJA), lawyers have the monopoly of representing other parties before the Danish courts. The types of activities or business that lawyers typically engage in are normally described as legal advisory services and legal representational services before the courts and public authorities or organizations and regarding legal questions or disputes in general. They also provide economical and other advisory services in connection with their primary business.

74. To obtain the title of advokat and be admitted to the Bar, a candidate must receive the Danish law degree cand.jur. (usually conferred after 5 years of study), perform at least three years of practical legal work under the supervision of an advokat, attend a supplementary 
post graduate education course, and pass the final oral exam. However, lawyers who have been admitted in another EU Member State can practice this profession on a permanent basis in a self-employed or salaried capacity in Denmark under the professional title of their home state.

75. All Danish lawyers are members of the Danish Bar and Law Society. Lawyers who have obtained an admission in another EU Member State who wish to practice in Denmark must also be registered at the Danish Bar and Law Society and are subject to its various disciplinary functions based on the law and ethical rules, especially its code of conduct.

Notaries and other independent legal professionals

76. In Denmark, notaries are county court judges who do not provide services for clients. There are no other independent legal professionals in Denmark.

Accountants

77. Denmark has 2,742 persons as registered public accountants and 1,992 persons registered as state authorized public accountants. The DCCA appoints a commission (Revisorkommissionen) which examines, registers, and licenses registered public accountants and state authorized public accountants. Only registered accountants are permitted to audit companies' (limited liability) accounts according to the Danish Companies' Accounts Act.

78. Denmark also has accountants who are not registered or licensed by the DCCA. They are permitted to audit private enterprises with no limited liability. Some of these accountants are registered in the CVR but not as a separate business, so the number of such accountants is not known.

Trust and Company Service Providers

79. In Denmark Trust and Company Service Providers are not recognized or registered as a separate business area or profession. Lawyers and accountants normally provide trust and company services.

80. According to the 2006 MLA all Trust and Company Service Providers must be $\mathrm{AML} / \mathrm{CFT}$ registered in the future by the DCCA and also AML/CFT supervised by the Agency.

\section{c. Overview of nonprofit organizational sector}

81. Denmark has a vibrant, diverse, and active NPO sector. About 66,000 NPOs have chosen to register with the authorities and obtained a CVR number. It is estimated that another 20,000 smaller organizations have not taken this step. 
82. Danish NPOs can take the form of either associations or foundations. In Danish law, a foundation is formed by a founder, who irrevocably alienates at least DKK 250,000 (EUR 33,525) in assets for objectives set out in the articles of association. There are no specific legal steps required to establish an association.

83. Recent academic research surveyed about 3000 national voluntary associations in Denmark, and found roughly 1,250 business and professional associations (including trade unions), 700 devoted to sports and recreation, and the rest focused on education and research, health, social services, the environment, development and housing, law, advocacy and politics. The survey found 178 associations working in the area of international affairs and 64 religious associations. The study also looked at the sub-national level, finding 5,764 associations in one of Denmark's 13 counties, of which some 2,400 were autonomous and the remaining 3,300 were branches of national associations. (Isbsen, Bjarne (2006) "Associations in Denmark," Center for forskning I Idraet, Sundhed of Civilsamfun, University of Southern Denmark.)

84. 104 of the largest Danish NPOs, representing an annual turnover of DKK 4.3 billion (EUR 577 million), are members of the self-regulatory organization, ISOBRO.

85. Work on the financial flows through the Danish NPO sector is still in progress, but ISOBRO estimates that its members receive over 70 percent of their funding from Danish Government, EU, or UN sources. The remaining 30 percent of funding comes from the private sector, either from collections, donations through payroll deductions, membership fees, or the sale of merchandise. These data are confirmed by more detailed reports from 3 large NPOs, which reported private individual donations of between 0-35 percent of income. In 2003-04, there were between DKK 500-534 million (EUR 67-71,6 million) in tax deductible donations to Danish NPOs.

\subsection{Overview of commercial laws and mechanisms governing legal persons and arrangements}

86. Businesses in Denmark are registered in different registers based on the nature of the entity. All business are also registered in the CVR. At the time of the assessment approximately 580,000 businesses were registered in the CVR.

87. The CVR collects all data contained in the other registers (which are held by the DCCA and the Tax authorities); regarding registration requirements the provisions detailing the information which is to be requested, the obligation to disclosure certain circumstances (such as change in the ownership/control or management structure) as well as the powers available to the competent authorities (the DCCA) are scattered in several pieces of legislation.

88. The data entered in the CVR is available to the authorities and the public, including online. However, with one exception, no information on the beneficial owner of an entity is available in the CVR. For some types of companies, information about beneficial ownership 
is available in certain circumstances in private registers such as company books. In the case of foreign companies registered in Denmark, beneficial ownership information is not available.

89. Danish legislation permits for the formation of the following legal persons:

a) Public companies (aktieselskaber, A/S). (Number: 39.406).

b) Private companies (anpartsselskaber, ApS).(Number: 119.025).

c) Companies or associations with limited liability (selskaber og foreninger med begrænset ansvar, S.M.B.A/F.M.B.A.).

d) Limited liability co-operatives (andelsselskaber, A.M.B.A.).

e) Limited partnerships (kommanditselskaber, K/S).

f) Partnerships with personal liability of partners (interessentskaber, I/S).(Number 36: 4.627).

g) Commercial foundations. (Number: 1.234).

h) European Economic Interest Grouping (EEIG). (Number: 15).

i) European Companies (SE). One Danish company has merged to a SE with its registered address in Sweden.

90. In general, all these legal persons have full legal capacities. However in the case of A/S, ApS, V.M.B.A., A.M.B.A., commercial foundations, and EEIG, the entity is not recognized as legal person until it has been registered.

91. An A/S has a board of directors, which must consist of at least three members and which is elected by the general assembly. The board of directors must appoint a board of management which must have at least one member. The majority and the chairman of the board of directors must not be members of the board of management. The structural and organizational possibilities of the legal personality of an A/S are regulated by special legislation, the Danish Public Companies Act (aktieselskabsloven, DPCA).

92. The A/S must have a share capital of minimum DKK 500,000 (EUR 67,050) which shall be fully paid-up, in cash or in kind before registration. The company may be formed by one or more founders. There are no residential requirements for the founders, the members of the board of directors and/or of the management board of an A/S. All individuals appointed to boards as well as auditors of company must be registered with DCCA.

93. The articles of association shall include provisions about, among other things, the name of the company; the local authority in Denmark in which the company is to have its registered office (head office); the objects of the company; the amount of the share capital; the denomination (nominal value) of the shares and the shareholders' voting rights; the number or the minimum and maximum number of members of the board of directors and any alternates for such members as well as the term of office of the members of the board of directors; the number or the maximum and minimum number of auditors as well as the term of office of the auditors; whether the shares are to be made out to a named holder or may be made out to bearer. 
94. $\mathrm{A} / \mathrm{S}$ can issue bearer shares up to the entire capital of the company. In such instances information on beneficial ownership is available only for shareholders that have holdings above a designated threshold.

95. An ApS may have a board which can consist of one member only. The structural and organizational possibilities of the legal personality of an ApS are regulated by special legislation, the DPCA (anpartsselskabsloven). Incorporation requirements are like those provided for an A/S except that the share capital minimum is DKK 125,000 (EUR 16,762). The company may only pay the preliminary expenses to the extent that the costs can be covered by the amount that the company has received on the subscription for the shares in excess of the nominal value of the shares. There are no residential requirements for the founders, the members of the board of directors and/or of the management board of an ApS.

96. The articles of association shall at least include provisions about the name and any secondary names of the company; the local authority in Denmark in which the company is to have its registered office (head office); the objects of the company; the amount of the share capital; the shareholders' voting rights; the management of the company; the accounting reference period of the company and the appointment of the auditor (section 5 of DPCA).

97. The memorandum of association must include provisions about the names and addresses of the promoters, the members of the management board and the auditor of the company; the allotment of shares to the individual promoters; the issue price of the shares; and the costs incurred in connection with the formation which the company is to discharge.

98. A S.M.B.A/F.M.B.A. is a company that can be established with no capital requirements nor governance rules. This type of company is not regulated in detail by special legislation but is subject to the requirements set forth in the Danish Act on Undertakings Carrying on Business for Profit (lov om visse erhvervsdrivende virksomheder), which is applicable to a number of limited liability businesses without specific, in-depth legislation. The Danish Act on Undertakings Carrying on Business for Profit regulates key issues such as name, powers of procuration of the undertaking, registration and legal personality, annual accounts and auditing and dissolution.

99. An A.M.B.A. is regulated by the Danish Act on Undertakings Carrying out Business for Profit. Its objects must be to help promote the common interests of the members through their participation in the business activities as buyers, suppliers or in any other, similar way, and whose profit, other than normal interest on the paid-up capital, shall either be distributed among the members in proportion to their share of the turnover or remain undistributed in the undertaking.

100. The promoters must draw up articles of association and/or lay down the name, address, the objects of the company, the accounting period of the company and who has the right to sign for the company. As limited liability company A.M.B.A. must file annual accounts. 
101. In a K/S one or more members, the general partners are personally and jointly and severally liable, without limitation, for the debts and obligations of the undertaking, whereas one or more members, the limited partners have limited liability for the debts and obligations of the undertaking. A K/S is regulated by parts of the Danish Act on Undertakings Carrying out Business for Profit, with regards to name and powers of procuration of the undertaking.

102. In an I/S all members are personally and jointly and severally liable, without limitation, for the debts and obligations of the undertaking. An I/S is regulated by parts of the Danish Act on Undertakings Carrying out Business for Profit, with regards to name and powers of procuration of the undertaking. The company is formed by an agreement between the participants. This is only regulated by the general law of contracts.

103. A commercial foundation can only distribute funds to receivers or objectives that fulfill the purpose described in the articles of associations. Amendments to the articles of association can only be made with the permission of the foundation authority, the DCCA, and the consent of the minister of Justice. A commercial foundation has a board of directors which must consist of at least three members and may have a board of management. The majority and the chairman of the board of directors must not be members of the board of management. The structures and reorganization possibilities of the legal personality of a commercial foundation are regulated by special legislation, the Danish Act on Commercial Foundations (lov om erhvervsdrivende fonder).

104. The commercial foundation shall have a capital of minimum DKK 300,000 (EUR 40,230) that shall be fully paid-up. The promoters must draw up articles of association that state the name of the foundation, its promoters, its registered office, its objects, the amount of capital and how it is paid-up, any special right for the promoters or others, the number of board members and how the procedure of election, accounting issues including the accounting period of the company and the appropriation of profits.

105. An EEIG is regulated by Council Regulation (EEC) No 2137/85 of 25 July 1985 on the European Economic Interest Grouping (EEIG) and the Danish Act on Administration of the EEC Regulation introducing EEIGs. The regulation stipulates that the purpose of a grouping shall be to facilitate or develop the economic activities of its members and to improve or increase the results of those activities; its purpose is not to make profits for itself. Its activity shall be related to the economic activities of its members and must not be more than ancillary to those activities.

106. An EEIG must be formed by at least two parties, companies or natural persons, who carry out any industrial, commercial, craft or agricultural activity or who provide professional or other services in the Community. The parties remain independent persons as well as parties of the EEIG. The parties must conclude a contract that stipulates the name of the grouping, the official address of the grouping, the objects for which the grouping is formed, the name, business name, legal form, permanent address or registered office, and the 
number and place of registration, if any, of each member of the grouping and the duration of the grouping, except where this is indefinite.

107. An European Company is regulated by Council Regulation (EEC) No 2157/2001 of 8 October 2001 on Statute for a European Company and the Danish Act on Administration of the Regulation. The Regulation stipulates that it will permit the creation and management of companies with a European dimension, free from the obstacles arising from the disparity and the limited territorial application of national company law. The essential objective of legal rules governing Sees is to enable companies from different Member States to merge or to create a holding company and enable companies and other legal persons carrying on economic activities and governed by the laws of different Member States to form joint subsidiaries.

\subsection{Overview of strategy to prevent money laundering and terrorist financing}

\section{a. AML/CFT Strategies and Priorities}

108. As an EU member state, Denmark has and continues to link its domestic strategies and priorities with those developed in Brussels. The MLA was enacted in 1993, transposing the $1^{\text {st }}$ Money Laundering Directive-1991/308/EC into national legislation.

109. In 1997, the Ministry of Justice (MOJ) set up the Committee on Economic Crime and IT Crime which dealt with possible reforms of the money laundering legislation as well.. In 1999, the Committee finished a report on money laundering provisions in the Criminal Code and recommended an "all crimes"-approach. A new provision with this content entered into force 1/7 2001. Based on information from the FIU, typologies reports from FATF, information from Interpol and the Egmont Group etc. the Committee finished a report on preventive money laundering legislation in 2004. The work was somewhat delayed awaiting the $2^{\text {nd }}$ EU Directive on Money Laundering.

110. The MLA was substantially amended in June 2002, following the events of 9/11, the adoption of the $2^{\text {nd }}$ EU Directive on Money Laundering and issues concerning the fight against terrorism and financing of terrorism, including the adoption by the FATF of the special recommendations on terrorist financing. Terrorist financing has since been the major priority for the authorities.

111. Since 2002 there has been several minor amendments of the MLA, the latest amendment was in March 2005.

112. The draft MLA comprises suggestions from the Committee on Economic Crime and IT Crime, the revised FATF recommendations and the $3{ }^{\text {rd }}$ EU Directive on Money Laundering and Financing of Terrorism. The authorities awaited the finalization of the latest EU Directive before updating MLA, rather than amending the legislation in stages. 
113. The draft MLA was presented to Parliament on 9 November 2005. The first reading in the Parliament was on 19 November 2005. The legislation was enacted on February 21, 2006 and entered into force on March 1, 2006, except for some provisions that will enter into force on January 1, 2007 (i.e., concerning PEPs, correspondent banking, non face-to-face transactions, new payment technologies and monitoring of unusual transactions), to accommodate requests from the private sector to grant financial institutions more time to update their policies, procedures and systems.

114. The Danish authorities also have worked on improving the FIU's IT system and establishing a permanent system with contact persons in all police districts to receive more information on money laundering in cases with no STRs. This has been required since 30/6 1993 based on a circular letter from the MOJ and the police districts have regularly been reminded by the Public Prosecutor for Serious Economic Crime. The requirement was repeated in a circular letter of 7/3 2005 from the MOJ.

115. The authorities have placed priority on domestic and international cooperation. They recognize that awareness-raising efforts for the regulated sectors need to be improved. Some sectors may still need more guidance like money laundering indicators. Such indicators have mainly been given to/discussed with banks, insurance companies, foreign exchange offices, money remitters, casinos and lawyers. Denmark has few national cases from which to draw indicators and the collection of information from other countries has taken place over a longer period of time and is now being converted into sector specific indicators, the intention being to distribute these indicators in connection with a brief introduction to the requirements of the new MLA. General indicators have been provided in the 2004 annual report of the FIU. The report is also made public on the Internet. Danish authorities intend to start outreach campaigns to those regulated sectors where close cooperation has not yet established. Outreach to less organized sectors poses a significant challenge.

116. In Denmark the Danish Security Intelligence Service and the Public Prosecutor have worked with a number of non-governmental organizations to publish a leaflet (in seven languages) entitled "Your contribution can be misused". It describes the Criminal Code provisions on the financing of terrorism and explains what people can do to make sure their donations to non-profit organizations are not actually being used to finance terrorism. Work is also in progress to publish a similar leaflet for persons responsible for money transfers outside the more formal systems. The authorities intend to continue working with such representatives in order to raise awareness in this field.

117. Danish authorities have organized much of their work related to financial crime in specialized task forces, which collaborate closely with the FIU. These task forces have focused:

1. on a group (e.g. biker groups where the general work is supplemented with special cooperation between the National Crime Intelligence Service under the National Commissioner and the customs and tax authorities), 
2. on a person (e.g. a person who had a pattern concerning establishing of companies and increasing the share capital which resulted in a task force with participants from the Copenhagen Police, the Public Prosecutor for Serious Economic Crime and the Commerce and Companies Agency),

3. on a type of crime (e.g. new types of VAT fraud which resulted in a task force with participants from the customs and tax authorities and the Public Prosecutor for Serious Economic Crime), or

4. on a possible starting point for discovering crimes including tax frauds and money laundering (as e.g. Danish citizens comprehensive use of foreign credit cards in Denmark looked into by a task force with participants from the customs and tax authorities and the Public Prosecutor for Serious Economic Crime).

\section{b. The institutional framework for combating money laundering and terrorist financing}

\section{(i) Ministries}

\section{Ministry of Justice}

118. The MOJ in Denmark is responsible for the general law enforcement and prosecution matters and has responsibility for the preparation of legislation concerning the Criminal Code, the Administration of Justice Act, the Gambling Casino Act, the Act on Measures to Prevent Money Laundering and the Financing of Terrorism, among others. The MOJ also supervises the Office of Public Prosecutor for Serious Economic Crime, which has responsibility at the national level for prosecution of the most complex and serious cases of economic crime. The MOJ oversees the Police Department including the Office of the National Commissioner of Police, and acts as the Danish Central Authority for mutual assistance in criminal matters. The MOJ has the power to issue licenses to casinos and to authorize lawyers to practice law.

Ministry of Economic and Business Affairs

119. The Ministry of Economic and Business Affairs develops policy for the financial sector and addresses matters important to the business environment within Denmark. Its responsibility in the preparation of legislation extends to such matters as money laundering, accounting and book-keeping, auditors, and companies. The Financial Supervisory Authority, the Commerce and Companies Agency, and the Agency for Enterprises and Construction fall under the supervision of the Ministry.

Ministry of Foreign Affairs

120. The MFA is responsible for the foreign policy aspects of the fight against the financing of terrorism including UN Security Council matters and aspects of international cooperation. It represents Denmark in the different UN working groups, including the Counter Terrorism Committee and the Al Qaida/Taleban Committee. The MFA coordinates the Danish positions on financing of terrorism issues in international fora and ensures that the 
United Nations Sanctions list against Al/Qaida and the Taleban is distributed among the different ministries and departments. It is also responsible for coordinating the Danish position on the EU's implementation of UN Security Council Resolution 1373.

Ministry of Taxation

121. The Ministry of Taxation has an indirect involvement in AML-CFT matters. It oversees the Central Customs and Tax Administration which monitors cross-border transactions under the Customs Act. It is also the repository of revenue and other information that is relevant in the investigation and prosecution of money laundering and the financing of terrorism. Its functions also include preparing legislation regarding tax and customs matters.

\section{(ii) Law Enforcement, criminal justice and operational agencies}

The Police

122. The police force maintains law and order within the territory of Denmark. There are 54 police districts that investigate criminal matters, including matters that arise through suspicious transaction reports that are referred to police districts by the FIU. Police authorities also assist in the investigation of financing of terrorism cases. Changes have been recommended to the structure of the police force that would lead to a reduction in the number of police districts from 54 to approximately 12 .

Public Prosecution Service

123. The prosecution service is part of the MOJ and under the direct control of the Director of Public Prosecution. The Director of Public Prosecution conducts criminal cases before the Supreme Court and supervises the work of the Public Prosecutors including regional public prosecutors who conduct criminal and appellate cases before the High Courts. Public prosecutors are also assigned in each Police District. There are also two specialized prosecution offices at the national level.

\section{Office of Public Prosecutor for Serious Economic Crime}

124. The Office of Public Prosecutor for Serious Economic Crime is part of the Public Prosecutor's Office and is responsible for the investigation and prosecution of serious economic crimes in Denmark and, more specifically, organized crime that is particularly extensive in scale. It covers the country as a whole.

Money Laundering Secretariat (FIU)

125. In 1993, the Money Laundering Secretariat (the FIU) was established as a unit within the Office of the Public Prosecutor for Serious Economic Crime. The Secretariat receives, analyses and disseminates suspicious transaction reports linked with ML/FT.

Customs and Tax 
126. The Central Customs and Tax Administration is responsible for the monitoring of cross border transactions over 15,000 euro and report suspicious transactions to the FIU. Officers have no law enforcement powers and provide all information relevant to any particular case to the police or the FIU for investigation.

Danish Security Intelligence Service

127. The Danish Security Intelligence Service, a unit within the Office of the National Commissioner of Police, functions to prevent and investigate actions that may put the security of the state at risk. As it relates to the financing of terrorism, the Service gathers intelligence and assists in relevant investigations.

The Steering Group on the Financing of Terrorism

128. The Steering Group is the mechanism for cooperation between the Danish Security Intelligence Service and the Public Prosecutor for Serious Economic Crime. The Steering Group considers cases under investigation as well as general questions, and serves as the national contact point for cooperation with Europol on countering the financing of terrorism

The Serious and Organized Crime Agency

129. The Agency is a unit within the Office of the National Commissioner of Police. It is responsible for monitoring organized crime in Denmark, and comprises the National Crime Intelligence Service, the National Crime Squad, the Communication Centre and the Counter Terrorism Unit. It provides support to the police districts in combating serious organized crime. It has the responsibility for the monitoring, validation, systematization and storing of data as well as analysis of intelligence from both national and international sources related to organized crime. It also coordinates efforts to monitor controlled deliveries.

The Steering Group on Organized Crime

130. This Committee comprises the Commissioner of Police and the Director of Public Prosecution together with high level representatives of the police and prosecution office. It meets twice yearly and coordinates all efforts to combat organized crime in Denmark.

The Money Laundering Steering Committee

131. The Money Laundering Steering Committee was set up by the MOJ in 1993 when the FIU was established. It comprises representatives from the National Commissioner, the National Crime Intelligence Service, the Chiefs of Police Associations, the Copenhagen Commissioner, and the Office of Public Prosecution for Serious Economic Crime. It deals with matters as feedback from the police districts, changes in assignments for the investigation of STRs and general FIU-police cooperation issues in relation to STRs and money laundering investigations. 


\section{(iii) Financial Sector Bodies}

\section{The Financial Supervisory Authority}

132. The Financial Supervisory Authority is under the responsibility of the Minister for Economic and Business Affairs and exercises its authority through three agencies; the two councils for supervisory activities, and the Ministry for regulatory activities. The main responsibilities of the FSA are supervision, regulation and information. The FSA has a staff of 190 professional and administrative officers. Its supervision responsibility can be divided into those of supervising the financial undertakings and the securities markets. The supervision of financial undertakings comprises banks, mortgage credit institutions, insurance companies, pension funds, insurance brokers, investment companies, and investment associations and investment management companies, financial holdings companies as well as the securities areas. Market supervision includes undertakings permitted to operate stock exchanges(securities exchanges), authorized markets, securities brokers, money market brokers, clearing undertakings and registration undertakings.

The Commerce and Companies Agency

133. The Commerce and Companies Agency also has supervisory responsibility over persons and legal entities that provide a service for the transmission of money or money value. As part of this function, it conducts on-site inspections to check if the money transmitter requires the mandatory information about the identification of the client. It has also issued guidelines to all transmitters informing them about their duties under the MLA and their obligation to report suspicious transactions linked to ML/FT to the FIU.

The National Agency for Enterprise and Construction

134. The National Agency for Enterprise and Construction forms part of the Ministry of Economic and Business Affairs and is responsible for the administration of of EU regulations on restrictive measures (sanctions), including EU regulations implementing UNSCR and questions relation to freezing.

The Bankers Association

135. The Danish Bankers association is an organization that groups all the banks and has 156 members which includes savings banks, and Danish branches of foreign banks.

The Bankers Association Money Laundering Group

136. The Danish Bankers Association's Money Laundering Group consists of representatives of the Bankers Association, the Association of local banks, the FIU and the FSA. Its responsibility is to discuss all issues relating to money laundering and trends and developments, freezing procedures and the financing of terrorism. The FIU gives general feedback to the group and there is an exchange of experiences about issues concerning 
AML/CFT. The Association has issues guidelines on money laundering and the financing of terrorism in collaboration with the FIU.

The Central Bank (Danmarks Nationalbank)

137. The Central Bank has the legal status of an independent body governed by public law. The Central Bank does not have any supervisory powers or similar responsibilities with regard to the MLA. The Central Bank is covered by the MLA when it conducts activities similar to the Danish banks. Consequently, the Central Bank is required to comply with all of the provisions of the MLA when it conducts these activities.

The Association of Local Banks in Denmark (Lokale Pengeinstitutter)

138. The Association of Local Banks, Savings Banks and Co-operative Savings Banks in Denmark counts some 125 local banks, savings banks and co-operative savings banks in Denmark, the Faroe islands and Greenland. The membership comprises all Danish banks.

The Danish Securities Dealers Association (Børsmæglerforeningen)

139. The Danish Securities Dealers Association is open to members of the Copenhagen Stock Exchange or other Danish stock exchanges. The Association at present has 18 members, mainly larger domestic banks and local branches of foreign banks. All members of the Association - except for one branch of a foreign bank (who owns a Danish bank which is member of the Danish Bankers Association) - are also members of the Danish Bankers Association.

The Danish Securities and Broker Association (Den Danske Fondsmæglerforening)

140. The objective of the Association is to promote the common interests of the members and represent the members towards the Government, the Danish Parliament, other public authorities and the Arbitration Board for investment companies. According to the Rules of Association companies which are authorized either by the Danish FSA or the competent authority of their home country to perform service as investment companies in Denmark, are eligible for membership of the Association.

The Association of Danish Mortgage Banks (Realkreditrådet)

141. The Association of Danish Mortgage Banks is supervised by an executive board of eight members, who are selected in proportion to the size of the member mortgage banks. All the existing eight mortgage banks in Denmark are members of the Association of Danish Mortgage Banks. The mortgage banks grant loans against mortgages on real property based on the issuance of mortgage bonds; they cover 100 per cent of the mortgage finance market regulated by the Danish Financial Services Act and the Danish Mortgage Loans and Mortgage Bonds Act. 
The Danish Insurance Association (Forsikring \& Pension)

142. The Danish insurance and pensions market by the end of 2004 comprised 162 companies and 30 general pension funds offering insurance and pension products to corporate and personal customers alike. Life and pension insurance is underwritten by 30 general pension funds and 37 companies. As some companies are organized as groups, there are effectively 48 independent providers of life and pension insurance. The five largest groups/pension funds account for 55 per cent of total earned gross premiums.

The Federation of Danish Investment Associations (Investeringsforeningsrådet)

143. The associations are represented by their investment management companies. There are 14 investment management companies. While membership of the Federation is not compulsory, all associations managed by a management company are members. Only one association which has a board of management and not a management company is not a member. The Federation has issued ethic standards and fund governance rules. The Federation has not issued standards on prevention against money laundering. The Danish associations issue certificates to the investors through a credit institution. The certificates are registered in the Danish Securities Centre A/S. Most Danish associations and their management companies do not have contact with the customers, as they buy and sell the certificates through credit institutions.

\section{(iv) DNFBPs}

Commerce and Companies Agency

144. The Commerce and Companies Agency (DCCA) has a number of DNFBP supervisory responsibilities in the new Danish AML/CFT regime, in addition to its supervisory role vis-à-vis money transmitters and foreign exchange houses detailed above. Specifically, it will supplement its current market conduct supervision of accountants with AML/CFT supervision. It will also take on new supervisory responsibilities in relation to real estate agents and company service providers.

\section{Casinos}

145. The regulatory and supervisory regime for Danish casinos is highly decentralized. Each of the country's six casinos is under the supervision of the local police in municipality in which is it located. That supervision is effected by a team of independent inspectors who are present in the casinos during its operating hours. There is usually one inspector present for each 10 hour shift. The inspectors are employees of the municipalities, financed by a special levy on the casinos, and report to the local police. The police have the power to conduct on-site inspections and demand information from the owner or employees. Licenses are issued by the MOJ, which conducts fit and proper tests - including checks for criminal records - for all proposed owners and managers. These are renewed if and when there are 
changes. All casino employees must also undergo checks of their criminal record, and must notify if their status changes.

The Bar Association and Law Society

146. Lawyers are who have been admitted to the Danish Bar and who are authorized to practice law are subject to the disciplinary procedures of the Danish Bar and Law Society. All Danish lawyers and any EU lawyers who have been admitted to practice law in Denmark must be members. The Bar Association and Law Society is governed by a Council of 15 members which elects a President. If the Council finds that a lawyer has acted in conflict with the code of conduct it can lodge a complaint before the Disciplinary Committee which is operationally independent of the Council. The Disciplinary Committee can apply four different sanctions, according to the type and level of complaint. The first sanction is a warning, the second a reprimand, the third is fines up to DKK 200.000 (EUR 26,819), and the fourth a disbarment.

147. The authorities state that the Disciplinary Committee will play a less important role in relation to money laundering and the financing of terrorism as they anticipate that the any serious offenses will be dealt with in the criminal justice system. However, the Council may still, after consultation with the authorities, bring minor offences against the AML law before the Disciplinary Committee.

\section{(v) Non Profit Organizations}

148. The Public Collections Act regulates the public collection of funds and prescribes a monitoring mechanism for the public collection of funds and the use of such funds (see section 5.4 below). The MOJ has issued an order defining the procedure for the collection of public funds and the control of the use of such funds. The Act lays down a clear and mandatory procedure for the authorization of a public fund collection. The police has to be notified prior and the application for such collection has to be supported by a series of documentation and information. Any breach of the provision of the Act is subject to a fine.

\section{c. Approach concerning risk}

149. The enactment of the new MLA transposes into Danish legislation the EU Third Money Laundering Directive and therefore certain features of the risk-based approach introduced in the revised FATF Recommendations. In particular, it allows reporting entities to tailor their CDD procedures according to the degree of risk of the customer, transaction or business relationship and requires enhanced CDD measures in situations that are assessed as being of higher risk of ML and TF. The law also prescribes the types of customers, transactions and business relationships where reporting entities are exempt from having to conduct CDD. Reporting entities are also required to set out written rules and procedures concerning ML/TF risk assessment and management. 
150. The FSA has adopted a risk-based strategy where on-site supervision is given a high priority. An on-site inspection may be full scope, focused or follow up.

The on-site inspection program is split up in four components:

- Extended: Banks under increased surveillance (personal rating 1-3) full scope or focused every year.

- Special: Major banks and mortgage credit institutions with a risk area in focus every year, so that all significant risk areas have been reviewed within a 4-year period of time.

- General: Banks with rating 4-9 full scope every 4th year.

- Preventive: Very small banks with rating 4-9 full scope every seventh year.

The MLA also stipulates that the DCCA is to carry out its expanded responsibilities for AML/CFT supervision of bureaux de change, money remitters and DNFBPs on a risk basis.

\section{d. Progress since the last IMF/WB assessment or mutual evaluation}

151. The second mutual evaluation of Denmark was completed in February 1997. The evaluation report noted the following main deficiencies and weaknesses. Relevant actions taken by Danish authorities since 1997 are set forth after the notation of the deficiency or weakness.

152. The examiners found that a new money laundering offence should be created covering all serious crimes, including all crimes that generate a significant amount of proceeds. The offence should be based on the definition of money laundering in the MLA. Consideration should be given to creating a secondary offence where the mens rea is a lesser standard such as "reasonable presumption."

- In 2001, Denmark enacted a new receiving provision (Section 290 of the Criminal Code) that extended the predicate offenses for ML to all serious crimes. Section 290, as the previous provision (Section 284 of the Criminal Code), covered all kinds of ML activity. Denmark did not base the offense set forth in Section 290 on the definition of ML as set forth in the Danish MLA. The definition in the MLA was based on the EU Directive on money laundering which in turn was based on Vienna Convention text. Because there was an extended history within Danish criminal law under the receiving provision, and authorities viewed Section 290 as covering the same underlying conduct, authorities concluded that a significant change in the language used in the criminal provision might lead to a narrow interpretation of conduct to be covered and would cause confusion.

- $\quad$ The Committee within Denmark that made recommendations regarding a new criminal money laundering provision discussed whether there should be a change in mens rea requirement to cover "reasonable presumption." A majority within the Committee opposed such a change, and the recommendation was not adopted. 
153. The examiners commented that a proposed provision that would require a defendant in some instances to prove the legitimate origin of property would be a valuable addition to the confiscation legislation.

- In June 1997, Section 76a of the Criminal Code, which provides for a defendant to establish the legitimate origin of property in some circumstances, was enacted in Denmark.

154. The examiners recommended that Danish authorities supplement existing efforts to collect statistics particularly in relation to confiscation and international cooperation.

- $\quad$ Authorities have gathered some additional statistics since the 1997 evaluation particularly in FIU-related matters. However, statistics maintained relating to confiscation and international cooperation remain quite limited. Danish authorities recognize that they must begin maintaining such statistics and use them appropriately to evaluate their programs. Examiners noted that the banking sector would benefit from face to face education and training on current money laundering issues.

- Money laundering and terrorist financing issues are incorporated in the education of bank employees. In addition, the Bankers Association is planning seminars regarding the new MLA.

155. The examiners suggested that the FSA and FIU pay greater attention to non-bank financial institutions.

- $\quad$ Beginning in 2002, Danish authorities registered money transmission services with the FIU as the responsible agency. In January 2004, the DCCA was given responsibility for oversight of the registration of such services and their supervision. As of March 1, 2006, the DCCA is also responsible for the registration and supervision of bureaux de change.

- $\quad$ As of March 1, 2006, AML/CFT requirements apply to credit card companies, leasing and factoring companies not otherwise affiliated with banks and other lending companies (i.e., finance/consumer credit companies), for which the FSA is responsible for registration and AML/CFT supervision.

- While the above measures will contribute to increasing the effectiveness of the regime, the inspection policies and procedures, and practices of the FSA and DCCA for AML/CFT need to be enhanced

156. The examiners found that there had been no reports of suspicious transactions by the securities or insurance industries, that the securities industry lacked guidelines, and that representatives in both the insurance and securities sectors had noted difficulties in knowing what they should look for. 
- $\quad$ The lack of reports of suspicious transactions by the securities and insurance industries has remained a problem in the period since the last evaluation as reports have not been filed. In addition, although the insurance and pension association has issued guidelines, there are not yet guidelines for the securities industry.

157. A legal basis for the FIU to provide more feedback should be established as soon as possible.

- $\quad$ The MLA adopted in March 2006 remedies this problem with a specific provision on feedback. Danish authorities indicated that in the interim, as they awaited finalized 3rd EU Directive and revised FATF 40 Recommendations, they worked to provide feedback to the full extent it was permitted under the legislation on data protection.

158. The examiners found that bureaux de changes should be supervised.

- $\quad$ The MLA that came into effect in March 2006 provides that bureaux de change are subject to supervision for AML/CFT purposes by the DCCA.

159. The examiners found that employees in casinos should have better and ongoing training, that there should be guidelines, and that the level of supervision should be increased. In addition, customer identification data should be kept for more than two months.

- $\quad$ Training has been enhanced. While authorities note an increased the level of supervision, there should be more focus on AML/CFT compliance in the supervision. Regarding the maintenance of customer identification information, the Gambling Casino Act was amended in May 2000 to extend retention periods from two months to five years. Guidelines have been issued by casinos.

160. The examiners found that Denmark should consider extending the money laundering legislation to lawyers and accountants.

- In June 2002, the MLA was extended to lawyers and accountants. Authorities adopted the recommendation of the last FATF evaluation, but there remain issues regarding supervision for AML/CFT purposes and adequate STR reporting.

161. The examiners recommended that consideration be given to making possible a higher degree of cooperation between the Danish FIU and administrative FIUs.

- $\quad$ There is in practice no difference in the scope of cooperation the Danish FIU is able to afford to administrative FIUs compared with that given law enforcement FIUs. Danish authorities have noted that all requests from FIUs, whether administrative or law enforcement, made in accordance with the Egmont Group requirements, have been granted. Danish authorities must make a determination under the Danish Public Administration Act, that an exchange may take place. The standards under the Act can be met and this poses no issue in practice. 


\title{
DETAILED ASSESSMENT
}

\author{
Table 1. Detailed Assessment
}

\section{Legal System and Related Institutional Measures}

\section{$\underline{\text { Laws and Regulations }}$}

\subsection{Criminalization of Money Laundering (R.1, 2 \& 32)}

\section{Description and analysis}

162. Denmark has enacted a money receiving offence that serves as its ML provision. It meets the requirements for ML criminalization set forth in the Vienna and Palermo Conventions. Denmark's approach, which is through the offence of receiving stolen goods, is set forth in Section 290(1) of the Criminal Code. The provision, enacted in $2001^{3}$ to extend the ML offence to all predicate crimes, establishes two types of punishable acts:

first, the unlawful acceptance or acquisition for oneself or others of a share in profits which are obtained by a punishable violation of the law; and

second, the unlawful subsequent serving to ensure for another's benefit the profits of a punishable violation of the law by concealing, keeping, transporting, assisting in disposal or in a similar manner.

163. The first part covers acquisition and possession of profits, that is property that represents proceeds of crime, where there is knowledge that the property was obtained from an offense. (See, Article 3(1)(c)(i) of the Vienna Convention). The broad language of the second part of Section 290(1) of serving to ensure for another the profits, as established in Danish practice, covers all manner of assisting a perpetrator (or another) including conversion or transfer where there is knowledge that property is derived from an offense (see Article 3(1)(b)(i) of the Vienna Convention and Article 6(1)(a)(i) of the Palermo Convention ) and concealment or disguise of property (see Article 3(1)(b)(ii) of the Vienna Convention and Article 6(1)(a(ii) of the Palermo Convention). This section also covers some of the conduct set forth in, for instance, Vienna Convention Article 3(1)(c)(i) in the keeping of property. The sections do not specifically cover "use" of the property as set forth in Article $3(1)(c)(i)$ but the concept of "use" is included as confirmed by case law.

164. While in the Vienna Convention formulation, the predicate offender's concealment or disguise is covered, section 290(1) encompasses (in this second part) only a third party launderer's actions. When proceeding under the second part of section 290(1), the prosecutor must show that concealing, keeping, etc. was for the purpose of subsequently ensuring another's profit. Danish authorities note that that the "subsequent serving to ensure" of the profits need not be successful. This is based upon the Danish law and practice with respect to attempts (see section 21(1) of the Criminal Code.)

165. Section 290(3) contains an exception which prohibits punishment for those who accept profits as an ordinary subsistence from family members or cohabiters, or as a normal payment for ordinary consumer goods, articles for everyday use, or services.

166. Denmark also makes grossly negligent conduct subject to criminal sanction in some instances. Under 
section 303 of the Criminal Code, persons guilty of gross negligence "in acquiring by purchase or in receiving in any other similar manner objects acquired through an acquisitive offence" are criminally liable. This section, like Vienna Convention Article 3(1)(c)(i) addresses acquisition and receipt of property but is broader in that an offender only need be grossly negligent in the acquisition.

167. While the statutory language Denmark uses to criminalize ML as set forth in the section 290(1) receiving provision does not adopt the specific formulation set forth in the Vienna or Palermo Conventions, it appears to criminalize fully the same underlying conduct. ${ }^{4}$ The provisions do not specifically address "use" of property as set forth in Vienna Article 3(1)(c)(i). However, according to Danish authorities the concept of use is covered although not explicitly stated in the provision. In order to use one has to come into possession, and at least one court decision issued by the High Court in 2005 makes clear that a person's use is an activity that may be violative of section 290 (1). As FATF's Second Mutual Evaluation (1997) concluded with respect to the previous receiving stolen goods provisions (that also served as Denmark's ML offence), Denmark meets convention norms regarding the nature of the underlying conduct to be covered using its receiving stolen goods provision approach.

\section{$\underline{\text { Predicate Offences }}$}

168. Denmark has adopted an all crimes approach by making its ML statute applicable in the case of any punishable violation of law.

169. There are no limitations on the term "punishable violation of law." Profits from any violation, whether that be a violation of a Criminal Code provision or a violation of a provision in other legislation that sets forth a punishment however minor, come within the ambit of section 290(1). Denmark has offences (set forth in the Criminal Code and other acts) that relate to each of the designated categories of offences, and accordingly they may serve as predicate offences to the ML offence. For most of the offences, there is a range of offences:

Participation in an organized criminal group and racketeering: See "Question 6" below. Racketeering is covered by Sections 285-287, cf. Section 281, of the Criminal Code.

Terrorism, including terrorist financing: Sections 114-114 e of the Criminal Code.

Trafficking in human beings and migrant smuggling: Trafficking in human beings is covered by Section 262 a of the Criminal Code. Migrant smuggling is covered by Section 59 (7) of the Act no. 826 of 24 August 2005 (consolidation) on Aliens; under particularly aggravating circumstances, for the purpose of profits, by Section $125 \mathrm{a}$ of the Criminal Code.

Sexual exploitation, including sexual exploitation of children: Chapter 24 of the Criminal Code.

Illicit trafficking in narcotic drugs and psychotropic substances: Order of 31 August 1993 on Euphorant Substances (as amended); under particularly aggravating circumstances, Section 191 of the Criminal Code.

Illicit arms trafficking: Act no. 918 of 10 September 2004 (consolidation (as amended)) on Weapons and Explosives; for weapons and explosives that are particularly dangerous and capable of causing serious damage, illicit arms trafficking is covered by Section 192a of the Criminal Code.

Illicit trafficking in stolen and other goods: Section 290 of the Criminal Code.

Corruption and bribery: Active bribery, Section 122 of the Criminal Code, passive bribery, Section 144 and bribery in private affairs by Section 299, no. 2; bribery in arbitration, Section 304a of the Criminal Code.

Fraud: Sections 285-287, cf. Section 279 of the Criminal Code, and cf. Section 279 for computer fraud. 
Counterfeiting currency: Chapter 18 of the Criminal Code.

Counterfeiting and piracy of products: Cultural products, Act no. 725 of 7 June 2005 (consolidation (as amended)) on Copyrights; under particularly aggravating circumstances by Section $299 \mathrm{~b}$ of the Criminal Code. Non-cultural products, Act no. 1136 of 16 November 2004 (consolidation (as amended)) on Patents, Act no. 782 of 30 August 2001 (consolidation (as amended)) on Trade Marks, Act no. 1259 of 20 December 2000 (as amended) on Designs, Act no. 367 of 9 June 1998 (consolidation (as amended)) on Utility Models and Act no. 778 of 9 December 1987 (as amended) on the Rights on Topographies of a Semi-conductor Product.

Environmental crime: Several (about 200) laws and orders on environmental issues. Under aggravating circumstances by Section 196 of the Criminal Code.

Murder, grievous bodily injury: Murder Section 237 and grievous bodily injury by Sections 245 and 246 of the Criminal Code.

Kidnapping, illegal restraint and hostage-taking: Section 261 of the Criminal Code.

Robbery or theft: Robbery (Section 288 of the criminal Code); theft (Sections 285-287, cf. Section 276 of the Criminal Code).

Smuggling: Act no. 867 of 13 September 2005 (consolidation) on Customs; under particularly aggravating circumstances, Section 289 a of the Criminal Code.

Extortion: Sections 285-287, cf. Section 281, of the Criminal Code.

Forgery: Sections 172, cf. Section 171, of the Criminal Code.

Piracy: Section 183 a of the Criminal Code and references in Counterfeiting and piracy of products.

Insider trading and market manipulation: Act no. 843 of 7 September 2005 (consolidation (as amended)) on Securities Trading etc.

\section{Extraterritorial predicate offences}

170. Neither Section 290 nor other provisions in the Danish Criminal Code address explicitly extraterritorial application. However, ML offences are punishable even if the predicate offence has taken place in another jurisdiction if the underlying conduct also constitutes a criminal offence in Denmark. This is because for Denmark to assert criminal jurisdiction over a course of conduct not all, just an individual part, of the conduct will have had to occur in Denmark (for instance the laundering activity). In addition, under section 7(1)(no.2) of the Criminal Code, in the case of Danish citizens there is jurisdiction based upon nationality even when no part of the offence occurred in Denmark. Denmark has successfully prosecuted ML where the predicate offence was committed in another jurisdiction.

\section{$\underline{\text { Self-laundering }}$}

171. Though comprehensive in many other respects, Denmark's ML offence does not apply to persons who commit the predicate offence. Self-laundering is not an offence that is separate from the predicate crime. Rather it is viewed as part of the predicate offence activity.

172. Danish authorities indicate that self-laundering is not covered because of a fundamental principle in the Danish legal system that no one can be convicted of two different crimes concerning the same assets. It is an underlying precondition of the criminal law system that a person cannot be punished for the receiving of stolen 
goods (Section 290) and at the same time be held criminally liable as the principal perpetrator of the predicate crime or for complicity in relation to the predicate crime.

173. The Danish authorities provided support for this in criminal law texts dating from 1841 that comment on the fact that in the Danish system a person would not be found guilty for two independent crimes relating to receiving stolen goods and the primary criminal conduct relating to such property.Texts commenting on this in particular, or on a more general concept regarding the commission of crimes typically committed in ways that contain the violation of additional provisions, were provided dating from 1841, 1895, 1905, 1952, 1993, 2004 and 2005. In a 2005 text written by a former Supreme Court judge and Chief Prosecutor and two professors of criminal law, the authors conclude that the Criminal Code is built on the precondition that a person who is punished for receiving stolen goods cannot be punished for complicity in the primary crime. In addition, a Supreme Court case from 1893 was explicit in rejecting the city court's finding that a person could be guilty of receiving stolen goods in addition to theft.

174. Authorities indicated that the commission that considered the revision of the ML offence that resulted in the current Section 290, in its deliberative meetings, gave no more than very cursory consideration of the issue, because it was recognized as not consistent with the Danish approach to criminalization. Denmark's actions in not giving consideration to the issue as it amended the Danish law, or taking any steps towards enacting a provision although the Vienna and Palermo conventions mandate it unless otherwise required by fundamental principles of domestic law, indicate the fundamental nature of the issue in the Danish system as articulated also in the Danish legal texts.

175. As the Report of the Ad Hoc Committee on the Elaboration of the Convention against Transnational Organized Crime and attached Interpretative Notes for the official records (A/55/383/Add.1) make clear, Article $6(2)(e)$ of the Palermo Convention was meant to take into account "legal principles of several States where prosecution or punishment of the same person for both the predicate offence and the money-laundering offence is not permitted." It is the case with Denmark that there is a long tradition based upon principles fundamental to its system that prosecution and punishment for both the predicate and ML offences are not permitted.

176. While the evaluation team concluded that Denmark is in compliance with FATF Recommendation 1 in this regard, it was also of the view that Denmark might consider whether it could revisit this issue (as have a number of European countries in broader ways) at least in a narrow set of circumstances. It appears that the fundamental principle is directed primarily at not criminalizing twice what is, as a long standing matter, considered a single course of conduct, the unlawful taking and then the initial placement of the proceeds of unlawful activity. With the increasing sophistication of ML techniques and methods used by organized criminals to hide proceeds, once the initial placement occurs, there are often subsequent actions that become more and more disconnected with predicate offender's initial criminal conduct that produced the proceeds. Beyond initial placement (viewed in the Danish legal system as part of the original conduct), it could be that it would not be inconsistent with fundamental principle, viewed in light of new kinds of criminal conduct, for the continued actions in converting and reconverting, sending away and hiding, particularly when such actions are distant in time and place from the initial fraud, theft, etc. to be considered separate criminal activity.

177. Danish authorities indicate that the perpetrator of a crime who launders his or her proceeds will be charged with the predicate crime. However, if there is not enough evidence to convict on the predicate crime, the person can be charged with and convicted of ML. ${ }^{5}$

\section{Definition of Property}

178. The term profits is interpreted broadly and covers any type of property that directly or indirectly represent the proceeds of crime. Danish authorities indicate that the explanatory report relating to section 290 supports this, and "profits" cover every type of property (including for instance both objects and money), as long as it is identified as proceeds. It may be direct profits, surrogate or indirect profits or the income from such assets. A share in the profits includes some or all of the profits. 


\section{Establishing Property as Proceeds}

179. For a ML conviction, there must only be sufficient indications that property is proceeds (or alternatively that a person thought that property was proceeds even if it was not). There need not be a conviction on a predicate offence, nor an indication who committed it. The explanatory report on Section 290 notes that decisive in the application of the provision, as with the previous section (section 284 of the Criminal Code), is a showing that proceeds stem from a predicate offense as opposed to from legal activities. Case law establishes that establishing that proceeds are from crime rather than from legal activity can occur by presumption.

\section{Ancillary offences}

180. Danish law provides for a number of ancillary offences that are applicable in the case of all crimes including ML and FT:

Attempts: Section 21(1) of the Criminal Code addresses an attempt to commit an offence and applies to Section 290 offences. Acts that aim at the promotion or accomplishment of an offence punishable by four months or more are punishable as attempts when the offence is not completed. Even remote acts of preparation for a crime are included in the concept of an attempt, as long as a specific intent to consummate the crime can be proved. The penalty for an attempt is the same as for the offence, but under section 21(2) of the Criminal Code it may be reduced particularly if there is little strength or persistence in the criminal intention. Danish authorities have successfully used the attempt provision in ML offence prosecutions.

Complicity: Section 23(1) of the Criminal Code criminalizes complicit actions of all kinds including aiding and abetting as well as facilitating and counseling the commission of an offence. Under the section, the penalty for an offence applies to a person "who has contributed to the execution of the wrongful act by instigation, advice or action." A person is held responsible regardless of whether s/he will have or expects a share of proceeds or other benefits from the criminal conduct. Attempts to contribute to an offence may also be punished. Punishment may be reduced (from that set forth for the offence for which there was complicity) if a person only intended to give assistance of minor importance, or to strengthen an intention that already existed and if the offence was not completed or the intended assistance failed.

181. Danish authorities indicated that provisions in Danish law on attempt and complicity have a very broad scope in comparison with similar provisions in other penal systems. For instance, under Danish law, a person is subject to a criminal liability regardless of whether the principal of the crime can be identified. Also a person's participation in an organized criminal group's criminal activity is punishable directly as a violation of the substantive criminal provision, and as necessary may also be supplemented with use of the provision on complicity.

182. A person's participation in a conspiracy to launder proceeds would be punished as an attempt to launder under section 21 or as complicity in laundering under section 23 of the Criminal Code. A person who agrees with one or more other persons to commit a crime can be punished for an attempt to commit the criminal act although the crime is not committed. Under Danish law on attempts, even remote acts of preparation are covered. If not all participants to an agreement are to take an active part in the commission of the crime, the Danish provision on complicity can be used. Danish law does not require there be any special action taken to implement the agreement nor need an organized criminal group take part for there to be criminal liability. Danish authorities noted that conspiracy is not contrary to the fundamental principles of Danish law but it has not been necessary to enact a specific provision criminalizing conspiracy given the reach, based upon previous cases and practice, of other ancillary offences.

183. Under the traditional concept of conspiracy, if two or more persons agree to commit an unlawful act and take a step towards it, they are liable. In the Danish system, the fact that two or more persons have agreed to commit an unlawful act leads to criminal liability in the same manner as it would for one to have been a participant in an agreement and for there to have been some action taken to further the agreement. In these 
circumstances, the same conduct is covered and a specific conspiracy offence is not required.

184. Since the same conduct is criminalized but in a different manner, Danish authorities are also able to provide assistance in mutual legal assistance settings when the offence is conspiracy. The underlying conduct is subsumed under Danish law and if the conduct is meets dual criminality requirements (when required), assistance is provided. In a recent case, Danish authorities provided assistance in transferring a sentence where the conviction was for conspiracy to defraud. The offence was equivalent to complicity to engage in fraud under section 279, cf. section 23 of the Danish Criminal Code.

185. In some instances, early stage conduct is also addressed through direct criminalization of the such conduct. (See, e.g., financing of terrorism crimes set forth in sections $114 \mathrm{a}$ and $114 \mathrm{~b}$ of the Criminal Code.)

\section{The mental element}

186. The ML offence applies to natural persons that knowingly engage in ML. Section 19 of the Danish Criminal Code provides that violations of the Criminal Code must be committed intentionally to be punishable unless there is express provision otherwise. This intent may be direct intention, advertent negligence (probability intent) or malice (dolus eventualis).

187. The expert report for Denmark's draft Criminal Code 1930 included a definition of intention. "Intention exists when the actor knows that his act will lead to the fulfillment of the requirements of the law for the offence (actus reus), or when he sees the occurrence of the offence as necessary or predominantly probable consequence of the act, or finally when he only sees the occurrence of the offence as possible but would have acted even if he had seen it as certain." Although these concepts are not incorporated explicitly into the Criminal Code, authorities indicate it summarizes what is required under Danish law for criminal intention. This includes the traditional concept of "knowingly" that an actor is aware of the nature of his conduct and that it could reasonably cause the result.

188. In addition, intent may be inferred from objective factual circumstances. This is based upon the basic rule of freedom to consider the evidence, that is the principle of "conviction in time" (free moral judgment).

\section{Liability of Legal Persons for ML Offences}

189. Under Danish law, legal persons may be held criminally liable for having engaged in a violation of the Criminal Code including a violation of section 290. Under section 306 of the Criminal Code, companies, etc. (legal persons) may be held criminally liable for violations of section 290 in accordance with general supplementary provisions on the criminal responsibility of legal persons (sections 25-27, Criminal Code). Taken together, these provisions (sections 306, 290 and 25-27) provide for the criminal liability of a legal person if it can be shown that one or more natural persons in the company (or other legal person) intentionally committed ML. A specific natural person need not be identified, nor is there a requirement of a prior conviction of a natural person. In addition, the fact that a legal person bears responsibility does not preclude the natural person's individual responsibility.

190. Legal persons include but are not limited to public companies, private companies, limited liability cooperatives, partnerships, associations, foundations, estates, municipalities and state authorities, and in some circumstances one person businesses. Punishment of a legal person is by fine. Criminal liability of legal persons does not preclude other liability as for instance the withdrawal of a license or other civil or administrative liability.

$\underline{\text { Sanctions }}$

191. Denmark provides a penalty for natural persons convicted of a violation of its ML provision (the receiving offences set forth section 290(1) of the Criminal Code) of a fine or imprisonment for a term not 
exceeding one year and six months. Under section 290(2), if the receiving of stolen goods is of a particularly aggravated nature - this may be for instance because of the commercial character of the offence, or the amount of the gain obtained or intended, or because there were a large number of offences, the penalty is a fine or imprisonment for not exceeding six years. Under section 88(1) of the Danish Criminal Code, a person charged with several offences is liable only for the maximum for the most severe crime unless there are particularly aggravating circumstances, in which case the penalty may exceed the most severe penalty by a half. Accordingly, there may be circumstances when a person charged with aggravated money receiving is liable for up to nine years imprisonment.

192. The determination of whether to charge the offence as aggravated is within the discretion of the prosecutor who is guided by the nature and circumstances of the conduct and by past decisions. The kind of conduct that is "of a particularly aggravated nature" is not defined in section 290, as it is a general concept under Danish criminal law, although several circumstances that indicate aggravation (commercial character of the offence, the amount of gain obtained or intended to be obtained, large number of offences) are set forth. In the case of ML in determining whether conduct is aggravated, Danish authorities noted that prosecutors would consider matters such as the amounts involved, the number of violations, whether there were several persons participating, whether the criminal activity assumed a commercial nature and the degree of secretiveness and concealment. The approach to the receiving offense of providing for penalty levels based upon the level of seriousness of the conduct, and operating within a single offence with different levels of punishment is a general approach under Danish criminal law and applies also in the case of many other offences. As it applies to ML, only in minor very simple cases can the offender stay within Section 290(1) (the basic offence). Violations of section 303 (gross negligence in receiving proceeds) are subject to a fine or to imprisonment for any term not exceeding six months.

193. Under Section 50(2) of the Criminal Code, a fine can be imposed as a supplementary punishment to other forms of penalty in addition to imprisonment when the defendant obtained, or intended to obtain, gain either for himself or others through the offence. In the case of a fine that is not a supplementary punishment to other forms of penalty, the fine may range from one day fines to 60 day fines of indefinite amounts. The principle of the day fine system is that the number of the day fines imposed should reflect the seriousness of the offence. The amount of each day's fine is based upon the defendant's economic situation including for instance his/her daily earnings, capital resources and family responsibilities. Under section 51(1) of the Criminal Code, if there has been considerable economic gain from the offence, the court may impose a fine other than a day fine.

194. For legal persons, the applicable penalty is a fine (section 25(1) of the Criminal Code) and there is no defined maximum. The imposition of fines on legal persons is governed in principle by the same rules as apply in the case of natural persons. The nature of the offence, the capacity to pay and the obtained or intended gain or amount saved are all considered. (Section 51(3) Criminal Code.)

195. Under the statutory scheme, ML conduct is punishable by a maximum of six years which, although this is within a lower range when compared with many other countries, is comparable to the maximum in a number of countries in the region, consistent with minimum EU standards, and consistent with the Danish approach to penalties for other criminal conduct. However, as noted below, the penalties that have been imposed for ML offences have been low. In the case of negligent ML, there is a very low sanction (up to six months) which would appear to apply even when large amounts of proceeds are involved. There is a limitation to 18 months maximum in the case of basic receiving (section 290) which authorities indicate applies only in small receiving cases. This is consistent with like 18 month maximums for the basic offense for a wide range of other offenses under the Danish Criminal Code including fraud, theft, embezzlement, fraud and extortion. Although it may affect the balance with other criminal provisions, one approach to improving the level of sanction actually imposed would be to increase this maximum.

$\underline{\text { Statistics }}$

196. Since at least 2000, Denmark has maintained annual statistics on the number of investigations 
concluded and prosecutions and convictions occurring under section 290 and predecessor offences (sections 284 and 191a).

197. Danish authorities report the following statistics for concluded investigations of Section 290 of the

Criminal Code and predecessor section offences:

\section{Concluded Investigations by Year: Section 290 and Predecessor Sections}

\begin{tabular}{|c|c|c|c|c|c|c|}
\hline Year & 2000 & 2001 & 2002 & 2003 & 2004 & 2005 \\
\hline $\begin{array}{l}\text { Total ML* Investigations } \\
\text { concluded in the year } \\
\text { (convictions, acquittals, } \\
\text { other dispositions) }\end{array}$ & 1803 & 1957 & 1841 & 1932 & 1874 & 1865 \\
\hline $\begin{array}{l}\text { Total Number of } \\
\text { Convictions }\end{array}$ & 1311 & 1403 & 1267 & 1266 & 1196 & 1199 \\
\hline $\begin{array}{l}\text { Convictions resulting } \\
\text { in unsuspended } \\
\text { imprisonment }\end{array}$ & 251 & 238 & 258 & 244 & 199 & 240 \\
\hline $\begin{array}{l}\text { Convictions resulting } \\
\text { in suspended } \\
\text { imprisonment }\end{array}$ & 419 & 482 & 440 & 439 & 423 & 410 \\
\hline $\begin{array}{l}\text { Convictions resulting } \\
\text { in fines }\end{array}$ & 641 & 683 & 569 & 583 & 574 & 549 \\
\hline Acquittals & 58 & 66 & 81 & 58 & 65 & 38 \\
\hline Withdrawal of charges & 55 & 73 & 76 & 76 & 84 & 86 \\
\hline No charges & 372 & 408 & 406 & 529 & 520 & 532 \\
\hline $\begin{array}{l}\text { Other decisions (for } \\
\text { instance, warning) }\end{array}$ & 7 & 7 & 11 & 3 & 9 & 10 \\
\hline
\end{tabular}

*Section 290 Criminal Code for July 2001 and later; Sections 284 and 191a Criminal Code prior to July 2001.

Danish authorities report the following figures for the Section 303 offence (gross negligence offence): 


\section{Concluded Investigations by Year: Section 303 Criminal Code}

\begin{tabular}{|c|c|c|c|c|c|}
\hline Year & 2000 & 2001 & 2002 & 2003 & 2004 \\
\hline $\begin{array}{l}\text { Total Investigations } \\
\text { concluded (convictions, } \\
\text { acquittals, other } \\
\text { dispositions): Section } 303\end{array}$ & 122 & 98 & 124 & 97 & 97 \\
\hline $\begin{array}{l}\text { Total Number of } \\
\text { Convictions }\end{array}$ & 89 & 80 & 107 & 78 & 77 \\
\hline $\begin{array}{l}\text { Convictions resulting in } \\
\text { unsuspended } \\
\text { imprisonment }\end{array}$ & 4 & 4 & 4 & 3 & 0 \\
\hline $\begin{array}{l}\text { Convictions resulting } \\
\text { in suspended } \\
\text { imprisonment }\end{array}$ & 9 & 8 & 6 & 4 & 3 \\
\hline $\begin{array}{l}\text { Convictions resulting } \\
\text { in fines }\end{array}$ & 76 & 68 & 97 & 71 & 74 \\
\hline Acquittals & 5 & 1 & 6 & 3 & 2 \\
\hline Withdrawal of charges & 1 & 1 & 3 & 1 & 3 \\
\hline No charges & 25 & 15 & 12 & 13 & 14 \\
\hline Other decisions & 2 & 4 & 0 & 2 & 1 \\
\hline
\end{tabular}

198. As the table above relating to Section 290 cases makes clear, Denmark is regularly and actively using its ML provision and for a jurisdiction its size has instituted a significant numbers of prosecutions each year. However, authorities indicated that virtually all of the matters reflected in the first chart involved small scale section 290(1) offences (small scale receiving of stolen goods). Danish authorities have not maintained regular or firm statistics showing the number of prosecutions and convictions for aggravated conduct. On an anecdotal basis, they indicate they believe that in 2003, charges were instituted for aggravated laundering in 14 instances. These include charges (some of which have been concluded and others not) from two major drug trafficking investigations in which 11 persons were implicated, and three separate non-drug trafficking related matters each involving the purchase of stolen goods. In 2004, there were two new cases charged as aggravated receiving both drug-trafficking related. In addition, three receiving cases charged as aggravated conduct in drug trafficking cases remained from 2003. As no new charges for aggravated conduct under the ML provision were instituted in 2005 , there were 16 cases in the 2003-2005 period.

199. These statistics of course do not provide the entire picture of the possible results from (and thus relevant to the general effectiveness of) Danish AML initiatives. The criminal ML offence may not be employed specifically to address the criminal conduct that constitutes laundering because of the Danish system of sanctioning the self-laundering as part of the predicate activity. Nonetheless, the AML system as a whole may be causing the conduct to come to light through the reporting obligation, and may be deterring other conduct through the existence of both the reporting obligation and various sanctions. 
200. While the self laundering conduct is addressed from a criminal perspective in the predicate offence context, there is no additional penalty for the conduct other than the consideration given to the ML conduct (the self launderers' hiding and use of the proceeds) as a factor in increasing the sentence for the predicate offence. Even considering that some ML conduct may be addressed in predicate offence prosecutions, the number of cases that Danish authorities have undertaken for aggravated ML over the last three years (the only period for which anecdotal information was provided) is very limited (an average of approximately 5 a year). These have been for the most part associated with two major drug trafficking matters. Danish authorities suggest this is because in most economic crime matters, proceeds are sent abroad and Denmark is left with no perpetrators to prosecute, and because Section 290 cases may not be fully investigated or prosecuted where there are other more serious violations to pursue. This is because where the addition of a Section 290 charge would not increase the penalty, and prosecution for the 290 offence is not viewed as having a special preventive effect, authorities do not pursue such charges. However, it is worth noting that prosecution for the predicate offense is in some circumstances in the Danish context also a prosecution for the ML conduct through the predicate offence. Given this situation, serious ML conduct addressed through criminal prosecutions undertaken in Denmark may well be greater than that reflected in the anecdotal statistics on aggravated ML cases alone.

201. Although there may be a low level of financial or organized crime in Denmark relative to other jurisdictions, the very small number of Section 290(2) cases over an extended period suggests that Danish authorities should undertake a review of why this is the case looking in addition at the relatively small numbers of STRs, considering and attempting to document the ways in which ML conduct is addressed through other kinds of prosecutions, and at the same time make an effort to develop more cases that are sanctionable as aggravated conduct which authorities have indicated includes all but minor, simple cases.

202. Danish authorities have also maintained statistics on cases in which imprisonment for period of a year or more was imposed.

\section{Imprisonment (One Year or More) for Section 284/290 Offences by Year}

\begin{tabular}{|l|l|l|l|l|l|}
\hline $\begin{array}{l}\text { Section } \\
\text { 284/290 }\end{array}$ & $\mathbf{2 0 0 0}$ & $\mathbf{2 0 0 1}$ & $\mathbf{2 0 0 2}$ & $\mathbf{0 0 3}$ & $\mathbf{2 0 0 4}$ \\
\hline $\begin{array}{l}\text { Total Number } \\
\text { of 284/290 } \\
\text { cases in which } \\
\text { imprisonment } \\
\text { for one year or } \\
\text { more was } \\
\text { imposed. }\end{array}$ & 9 & 21 & 17 & 13 & 9 \\
\hline 1-2 years & 7 & 17 & 15 & 12 & 5 \\
\hline 2-3 years & 2 & 2 & 2 & 0 & 3 \\
\hline 3-5 years & 0 & 0 & 0 & 1 & 1 \\
\hline 5-8 years & 0 & 1 & 0 & 0 & 0 \\
\hline
\end{tabular}

203. Although ML activity may be sanctioned with up to six years imprisonment, in only three instances in the last five years has a person been imprisoned for more than three years. The vast majority of all cases (aggravated and non-aggravated) result in no imprisonment at all. While the length of imprisonment and number of cases in which it is imposed is not the only indicator of the effectiveness of ML criminalization, it is one factor that provides an indication of how effectively in practice ML criminalization is working and its capacity 
for deterring like conduct. In Denmark, penalties imposed in cases of ML have been low.

204. Better statistics need to be maintained which differentiate section 290(1) and 290(2) cases and that note the full range of sanctions imposed, and served or collected, in each instance.

205. An important factor for Denmark in the ongoing process of evaluating its AML program is the nature of the criminal cases it institutes. As noted above, Danish authorities should consider why the number of aggravated ML cases is small and has decreased over the years. Authorities should consider on a regular basis the additional statistics they begin to gather, and how to develop additional ML cases that are more than simple receiving cases and greater use of the provision to address laundering of proceeds of crimes in addition to drug trafficking.

Greenland and Faroe Islands

206. The provisions in Greenland and the Faroe Islands and issues relating to their implementation were not considered by the evaluation team on an in-depth basis. In Greenland under Section 78 of the Criminal Code and Section 3(2) of the Controlled Drugs Act (as applicable in Greenland), ML is limited to predicate offenses involving offences against property and certain drug trafficking criminal activity. Under the Greenlandic Criminal Code there are diverse sanctions such as a caution, safe custody for an indeterminate period, and imprisonment (which may not exceed ten years) available in each instance, but the Code does not stipulate maximum and minimum penalties for specific kinds of crimes. In the Faroe Islands, under Section 191, 191a and 284 of the Criminal Code, the ML offense is limited to predicate crimes as drug trafficking, theft, robbery, misappropriation, embezzlement, fraud and certain other crimes. Under Section 286(3) of the Criminal Code, the penalty for receiving stolen goods under particularly aggravating circumstances is a maximum of 6 years.

207. While Greenland and the Faroe Islands have criminalized ML and many major predicate crimes are covered, they not yet adopted provisions similar to the revised section 290 adopted by Denmark in 2001, nor are they yet parties to the Vienna and Palermo Conventions. The ML provisions in force in these jurisdictions do not yet meet current international standards and work is underway to bring provisions into compliance with international standards.

\section{Recommendations and comments}

208. Use the criminal ML provision more effectively by developing and prosecuting a larger number of cases involving serious ML.

209. Seek to increase the penalties actually imposed for violations of the ML provision.

210. Increase the maximum penalty available for the negligent money laundering offence.

211. Make the provisions that criminalize money laundering in Greenland and the Faroe Islands fully consistent with the requirements of Article 3 of the Vienna Convention and Article 6 of the Palermo Convention, and use one of the approaches to predicate offenses set forth in the FATF Recommendations.

212. Consider the extent to which Denmark may be able to criminalize self-laundering separately, recognizing that while not a FATF R. 1 requirement where contrary to the general principles of penal law, countries with similar legal systems have progressively moved towards providing for self-laundering as a separate offence that can be charged with a predicate offence.

213. Keep more comprehensive statistics on ML cases including the kinds of cases (Section 290(1) or $290(2))$ and predicate offences, and evaluate the reasons for the limited numbers of prosecutions under Section 290(2) 


\begin{tabular}{|l|l|ll|}
\hline & \multicolumn{1}{|c|}{ Rating } & \multicolumn{1}{c|}{ Summary of factors underlying rating } \\
\hline R.1 & LC & $\begin{array}{l}\text { ML provisions in Greenland and the Faroe Islands are not fully consistent } \\
\text { with international standards as reflected in the Vienna and Palermo } \\
\text { Conventions and FATF Recommendation 1 in that, for instance, the range } \\
\text { of predicate offenses is not adequate. }\end{array}$ \\
\hline R.2 & LC & $\begin{array}{l}\text { Denmark institutes very limited numbers of prosecutions under its } \\
\text { aggravated ML provision. }\end{array}$ \\
\hline 2.2 Criminalization of terrorist financing (SR.II \& R. 32) & $\begin{array}{l}\text { Penalties imposed for ML offence are low. } \\
\text { Denmark institutes very limited numbers of prosecutions under its } \\
\text { aggravated ML provision. }\end{array}$ \\
\hline
\end{tabular}

\section{Description and analysis}

214. Denmark criminalizes the financing of terrorism with three provisions each aimed at specific kinds of conduct covered by the Terrorist Financing Convention. Section 114a of the Criminal Code prohibits (whether directly or indirectly) granting financial support to, providing or collecting funds for, or making money or other financial assets or services available to a person, group or association that commits or intends to commit a terrorist act. Terrorist acts are defined by reference to section 114. Section 114a implements Article 2(1) of the Terrorist Financing Convention. This section makes financing of an individual terrorist or a terrorist organization (that is any person or entity that commits or intends to commit a terrorist act) for any purpose a criminal act.

215. If financing of terrorism is related to a specific crime, Denmark's approach to criminalization - in the original provision enacted to comply with the Terrorist Financing Convention - is through a person's complicity in the terrorism offense with sections 114 (terrorism offense) and Section 23 (complicity) of the Criminal Code applicable. Persons who have contributed to an act of terrorism by instigation, advice or action are punishable under section 23 of the Criminal Code with the same penalty as is provided for under section 114, namely up to life imprisonment. The interpretative note to SR II makes clear that provisions criminalizing complicity in a terrorist act are not sufficient to meet the SR II standard. These are, however, as noted, not the only provisions available in the Danish system.

216. A separate provision addresses conduct set forth in Convention Section 2(5)(c). Section 114b criminalizes the contribution by instigation, advice or action to furthering the criminal activity or purpose of a group or association that commits an offense under Section 114 or $114 \mathrm{a}^{\circ}$

217. Section 114 includes those acts that constitute offenses within the scope of the relevant United Nations treaties against terrorism (set forth the annex to the Terrorist Financing Convention) through reference to the applicable provisions of domestic law and covers as well the acts described in Article 2(1)(b) (acts "intended to cause death or serious bodily injury... when the purpose of such act, by its nature or context, is to intimidate a population, or to compel a government or an international organization to do or to abstain from doing any act"). Article 114 is drafted in a manner that makes it clear that it applies to acts that will affect the structures of any country or international organization, not merely those in Denmark. The provision is consistent with the Article 2 (1)(a) and (b) of the Terrorist Financing Convention.

218. Under the Danish scheme, it is sufficient for criminal liability that a person collects, provides or receives funds or other assets for a person or association that intends to commit a terrorist act (as defined by Section 114). There must be a showing that the funds were provided to a group or person that either has committed or has an intent to commit such an act. The intent of the terrorist or terrorist group to commit crimes 
may be shown through inferring the intent based upon objective factual circumstances. This is pursuant to the general civil law rule of freedom to consider the evidence that applies generally in criminal proceedings in Denmark.

219. Explanatory notes to Section $114 \mathrm{a}$, which provide details not contained in legislation and are considered by the courts to carry a high degree of legal weight, make clear that it is a punishable act to provide funds or financial services to both the legal and illegal activities of a terrorist group. Intent is required in relation to the fact terrorist acts are part of the activities or aims of the group. Participation in or support to an organization that has both humanitarian and terrorist aims are covered. Explanatory notes also make clear that intentional requirements envisioned involve all degrees of intent. They are, for instance, met if the contributor is aware of the activities or aims of the group, or if in the specific circumstances $\mathrm{s} / \mathrm{he}$ must have realized that the organization - among other things - commits or intends to commit terrorist acts.

220. Although the provisions do not expressly address that the funds could be used "in full or in part" for a prohibited activity or organization. Danish authorities indicate that the explanatory notes cover the point that funds or services to both legal and illegal activities are covered, and note also that under Danish legal standards it would be sufficient if some of the funds were used or intended for use for the prohibited purposes. The definition of the offence does not require that the funds have actually been used for the purpose of carrying out or attempting to carry out a terrorist act. Nor need the funds be linked to a specific terrorist act.

221. In addition, under Sections 21 and 23 of the Criminal Code, attempts to commit the offences and complicity in an attempt are also punishable. Thus, a person also commits an offence if he/she participates as an accomplice in or contributes in the commission of Section 114, 114a and 114b offences undertaken by another. Thus, the Danish legislation covers the acts set forth in Article 2(5) of the Terrorist Financing Convention.

222. Denmark's terrorist financing offences extend to any funds, whether from a legitimate or illegitimate source and to assets of every kind. Section 114a covers "financial support" "funds" "money and other assets" "financial assets or financial or other similar services." These notions cover all kinds of assets and are in accordance with assets as defined in the Interpretative Note to SR II.

223. Denmark's terrorist financing offences are applicable regardless of whether the person committing the offence is in the same country in which the terrorist or terrorist organization is located or the terrorist act occurred/will occur. Under the terms of Section 114a, provision/collection, etc. may occur in Denmark for terrorist organizations or activities elsewhere, and receipt may occur in Denmark for collections taking place elsewhere. Likewise under Section 114, a person may assist or be complicit in a terrorist act that occurs elsewhere and have liability under Section 114, and as noted, section 114 extends to cases where the terrorism aim is directed against a foreign country or international organization.

224. Financing of terrorism offenses may serve as predicate offenses to ML as Denmark has an all crimes approach to predicate offenses under Section 290 of the Criminal Code. Such offences are also subject to the same principles as the ML offence concerning inferring the intentional element of the offence from objective circumstances. In any criminal proceeding in Denmark including those that relate to financing of terrorism, evidence is assessed based upon the basic rule of freedom to consider evidence. This includes the concept that intent may be inferred from objective factual circumstances. Under Section 306 of the Criminal Code, a legal person may be held criminally liable for any violation of the Criminal Code. The criminal liability of a legal person does not preclude other sanctions such as, for instance, the withdrawal of a license, or civil proceedings against the legal person. Courts take into consideration the impact of other measures when determining the sentence.

225. Denmark has enacted significant maximum penalties for its financing of terrorism offenses. The penalty for complicity to terrorism under Sections 114 and Section 23 of the Criminal Code is up to life imprisonment. For violations of Section 114a, the penalty is up to ten years and Section 114b up to six years. 
Legal persons are subject to a fine that has no maximum.

226. In addition, under Sections 78(2) and 79(1) of the Criminal Code, persons convicted of a punishable offences may be debarred from or deprived of the right to continue carrying on a business that requires a public authorization (for instance a license), if given the nature of the offence, there is a risk of abuse of the position or occupation. Section 79(2) permits authorities to limit a person's rights as a manager or board member of a limited liability company (or certain other companies), or a foundation. The sanctions appear to the evaluation team to be proportionate and dissuasive.

227. Under Section 118a of the Criminal Code, for a prosecution under Section 114, 114a or 114b to take place (among others), the Minister of Justice must order the prosecution. Danish authorities explained that this is part of a long tradition reflected in the Danish Criminal Code that Chapters 12 and 13 contain certain offenses that relate to matters affecting the State that require Minister of Justice approval at the final stage. This in practice is not a barrier to prosecution and the Minister has approved prosecutions relating to the financing of terrorism. In addition, under Section 98(3) of the AJA, the Minister is required to inform Parliament if s/he gives instructions to the prosecutor.

228. Denmark has criminalized the financing of terrorism in compliance with the requirements of the Terrorist Financing Convention, and there do not appear to be impediments under Danish law to proceeding successfully in this area as ancillary offenses, extraterritoriality, sanctions and related matters are all appropriately addressed.

Greenland and Faroe Islands

229. However, neither Greenland nor the Faroe Islands have provisions similar to Sections 114-114e of the Danish Criminal Code nor has the Terrorist Financing Convention been extended to them. Greenland's current criminal code contains provisions that address acts committed with a terrorist purpose. Ancillary provisions that cover attempt and complicity are also set forth in the Greenlandic Criminal Code at Sections 8 and 9, and have the same broad scope as provisions in the Danish Criminal Code. This enables a narrow coverage for financing of terrorism acts through ancillary provisions (specifically complicity to a concrete terrorist act with a showing that the defendant has intent to commit the act), an approach as noted above that is not consistent with FATF SR II. The Commission on Greenland's Judicial System issued a report in 2004 that proposed, relevant to UNSCR 1373 implementation, adoption of the Danish Criminal Code provisions on terrorism and financing of terrorism, as well as other provisions that would assist in implementation of UNSCR 1373 such as the AJA provisions on seizure and the Danish Criminal Code provision 77a. Greenland Home Rule and others are commenting on the report and delays have occurred because of political changes in the Home Rule Government. Once comments are received, the proposed revisions will be reviewed by the Danish MOJ to ensure they facilitate Greenland's full compliance with UNSCR 1373.

230. In the Faroe Islands terrorist financing would be approached through complicity and attempt provisions (Section 21 and 23 of the Criminal Code) relating to underlying offences as homicide, arson, deprivation of liberty, hijacking, etc. As with Greenland, there is some coverage for financing of terrorism acts through complicity in the commission of a concrete terrorist act. However, the criminalization of terrorist financing solely on the basis of aiding and abetting, attempt, complicity, etc. does not comply with SRII.

231. The Danish government is working to ensure the full implementation of relevant conventions and UN Resolutions in the Home Rule legislation of Greenland and the Faroe Islands. There have been ongoing discussions between the Danish MOJ and representatives of the Faroe Home Rule to ensure full compliance with UNSCR 1373 in connection with discussions on possible transfer of responsibility for police and administration of justice affairs to the Faroe Home Rule, and more recently outside the framework of those discussions.

$\underline{\text { Recommendation } 32 \text { (terrorist financing investigation/prosecution data) }}$ 
232. Danish authorities reported that there have been no convictions for terrorist financing. There are two cases in which charges have been instituted each involving the collection or solicitation of funds. In one case, a non-profit organization and two persons are charged; in the other one person has been charged. In one additional case, there was an investigation of a non-profit organization but the case was closed after a conclusion that no violation had occurred. The Steering Committee of the Financing of Terrorism (which consists of SØK and the Danish Security Intelligence Service) maintains statistics on investigations and prosecutions that are commenced based upon STRs or from other sources. In addition, the National Commissioner of the Police keeps statistics on the number of matters that arise by criminal provision.

\section{Effectiveness}

233. Danish authorities are clearly ready to - and have - pursued financing of terrorism investigations and prosecutions. The effectiveness of Denmark's terrorist financing offences, however, cannot be fully measured because cases have not yet been considered by the courts. There are now two cases in which violations are charged involving, in total, three individuals and one organization. One of the cases is expected to be heard in the court system shortly. The offences also carry substantial penalties and this could have the effect of deterring illegal financing activities. Danish authorities did not provide a specific threat assessment with respect to terrorism/terrorist financing operations other than a general statement that there is some risk but independent press reports indicate some such activity may be occurring in Denmark. This is consistent with its activities in investigating and prosecuting FT activity.

\section{Recommendations and comments}

234. Denmark has criminalized FT in compliance with the Convention. However, as authorities recognize and are working on, Greenland and the Faroe Islands need to enact specific provisions that criminalize the financing of terrorist acts, terrorists and terrorist organizations in a manner consistent with the Terrorist Financing Convention and not continue to rely upon the current approach of complicity in the commission of a concrete terrorist act. TF offences should be designated as predicate crimes to ML. The current provisions, together with the fact that the Terrorist Financing Convention has not been extended to these jurisdictions and extradition problematic, leave Greenland and the Faroe Islands vulnerable in the area of terrorist financing.

\section{Compliance with FATF Recommendations}

\begin{tabular}{|l|l|ll|}
\hline SR.II & PC & \multicolumn{1}{c|}{ Summary of factors underlying rating } \\
\hline & $\begin{array}{l}\text { The criminalization of the financing of terrorism by Denmark is fully } \\
\text { compliant, but Greenland and the Faroe Islands have not yet adequately } \\
\text { criminalized the financing of terrorism, terrorists and terrorist } \\
\text { organizations. }\end{array}$
\end{tabular}

\subsection{Confiscation, freezing and seizing of proceeds of crime $(R .3 \& 32)$}

\section{Description and analysis}

235. Denmark has quite comprehensive and flexible confiscation laws that permit confiscation, as well as the alternative of fines, in a wide variety of circumstances. As a rule, confiscation is conviction-based and is a sanction (a criminal legal consequence). It is not mandatory; rather a court decides in each instance whether confiscation should be imposed and its extent. Confiscation is taken into account as the court imposes a sentence. In some instances confiscated property may be used to satisfy a claim for damages. Confiscation may be ordered at sentencing. Alternatively, under section 684(1) of the AJA, in some circumstances, the confiscation may be ordered in a separate proceeding. This gives prosecutors the option of proceeding with a confiscation order when proceeds are found at a later time after conviction. Under section 95 of the Criminal Code, the state has 10 years in which to pursue proceeds.

236. Confiscation extends to proceeds that have been transformed into other property. Denmark has a 
system of value confiscation, and a provision that permits preventive confiscation in the absence of a conviction (similar to in rem confiscation) (section 77a Criminal Code). In addition, provisions permit, in some circumstances, an alleviation of the burden of proof for the prosecution regarding the origin of the assets.

237. The general conditions for confiscation appear in the Criminal Code at sections 75 through $77 \mathrm{a}$. Section 75 provides for the confiscation of proceeds, instrumentalities used in (or intended for use in) the commission of any offence under Danish law as well as laundered property. Under section 75, either the proceeds gained from a criminal act or a sum equivalent to the proceeds may be confiscated. In addition, if necessary to prevent other offences or otherwise warranted, instrumentalities (objects used or intended for use in a criminal act) produced by the criminal act and objects with respect to which a criminal act has been committed (for instance laundered property), or a sum equivalent to their value, may be confiscated. These may be taken not only from a perpetrator but also from persons on whose behalf a perpetrator acted. The prosecutor need not establish the exact amount of the proceeds. If the size of the amount cannot be established, a sum "thought to be equivalent to the proceeds" may be confiscated.

238. Proceeds includes all economic benefits obtained through a criminal offence including indirect proceeds and income, profits or other benefits from the proceeds. This is based upon the explanatory notes that accompanied the ML criminal provision. In Danish practice, the economic benefit to the perpetrator is usually viewed as equivalent to the profit from the sale of the confiscated property. However, this is assessed on an estimated value basis with case law recognizing that the advantage need not be calculated on the basis of the facts of a specific case but rather based on an estimate.

239. In some circumstances, the defendant has the onus of proving the legal origin of assets. Under section 76a of the Criminal Code if the act committed is (i) of a nature which may entail a significant financial gain, and (ii) punishable by imprisonment of six years or more, the court may impose total or partial confiscation of property belonging to the defendant. The confiscation is not to take place if the offender renders probable that the property has been acquired legally. This provision permits authorities, in defined circumstances, to confiscate property of crimes other than the crime of conviction and take assets that a defendant is not able to show have a legal origin. Proportionality would apply. This provision has been used by Danish authorities in drug trafficking matters. Value confiscation is also permitted.

240. Section 77 permits confiscated property and instrumentalities to be used to satisfy claims of victims of a crime. It also requires that there be a reduction in the amount confiscated if an offender has paid compensation to an injured party pursuant to a sentence.

241. The Danish scheme also makes provision for confiscation for the purposes of prevention. Under section 77a of the Criminal Code, assets, money or objects may be confiscated if the measure is viewed as necessary to prevent a criminal act or if such property may be used in a criminal act. Preventive confiscation may occur even in the absence of a conviction. Denmark's preventive confiscation provision provides authorities, as needed, with the ability to seize assets that may be used to finance terrorism upon an appropriate showing. It provides an ability generally to seize to prevent criminal activity and to take that property that may be used in a criminal act regardless of whether the criminal actor is before the court.

242. Proceeds may be confiscated even if the perpetrator is deceased (sections 75(1) and 76(5), Criminal Code), but there is no direct provision for confiscation in the case of an absconding defendant. Rather, seized assets can only revert to the State based upon their status as unclaimed assets after an extended period of time, for instance 10 years.

243. Fines may also be imposed as a supplementary punishment where an offender obtained or intended to obtain gain for himself or others by the commission of the offence. (Sections 50 and 51, Criminal Code). In the Danish system, supplementary fines are used as an alternative to confiscation. In a case where criminal proceeds are not confiscated, the court will often consider whether in such a circumstance the fine should be increased. 
Third parties

244. Denmark provides for confiscation of criminal assets that are transferred to third parties. First, the general rule is that confiscation applies not only the an offender but also to persons to whom proceeds have been directly transferred (section 76(1) Criminal Code). Secondly, if the perpetrator (or the person to whom the proceeds have been directly transferred) transfers the proceeds to a third party, the proceeds may be confiscated (1) if the third party knew of the illicit origin of the assets or exercised gross negligence in this respect, or (2) if the transfer was at no cost. (Section 76(4) Criminal Code).

245. In the case of extended confiscation under section 76a, for assets from criminal activity that is not an offence of conviction, assets in the hands of a limited range of third parties with a special connection to the perpetrator are subject to confiscation. Specifically assets may be confiscated from two categories of third parties to whom illicit gains may have been transferred: first, the offender's spouse or cohabitant unless the marriage or cohabitation did not exist at the time of the acquisition or the property was acquired more than five years before the commission of the offence; secondly from a corporation in which the offender has a substantial interest unless the transfer occurred more than five years before the commission of the crime. Case law also supports treating assets as belonging to a perpetrator if it is reasonably clear the assets are available to him/her. For instance, one court in Denmark found a defendant was the real owner of an enterprise that was registered in his wife's name. In another, the High Court ordered confiscation of funds that had been transferred to overseas companies owned by a mother of one of defendants in an investment fraud case. The court found in reality the funds were not outside the perpetrators' control.

246. Legal remedies are available to protect third parties rights. Under section $807 \mathrm{c}$ of the AJA, the courts can at any stage of the case make a decision concerning the rights of any person including third parties. The request is brought before the court and the decision of the court is in the form of an order after all those with an interest in seized property have an opportunity to be heard. Typically third parties will contact the prosecutor who will either seek to lift a seizure of property or otherwise have the matter heard by the court.

\section{$\underline{\text { Seizure }}$}

247. Seizure can take place to secure both a property-based confiscation order and value orders. The concept of seizure within Danish law includes both a restraint where the property remains in another's possession, and seizure where the property is held by the authorities.

248. Sections 801-806 of the AJA set forth the rules on seizure. A seizure may take place to secure a claim for confiscation. (Section 801(2)). In addition, seizures may secure evidence, the State's claim for costs and fines, and a victim claim for compensation. (Section 801(2)). It may also take place when a defendant has been charged and is evading further prosecution in a case.

249. Any objects or goods owned by the suspect may be seized to secure a confiscation order. For an order for seizure (to secure a confiscation order) to issue, a person must be reasonably suspected of an offence that can be prosecuted under Danish law and the seizure must be considered necessary to secure the claim for confiscation. Danish authorities indicated the necessity of seizure to secure the claim means that prosecutors must ensure that they do not seek a coercive measure when less intrusive means would suffice. Authorities indicated it is not a necessity to show risk of dissipation.

250. If charges have been filed involving an offence that could result in imprisonment for 18 months or more, and an accused is evading prosecution, all a suspect's property including subsequently acquired property may be seized. (Section 802(3) AJA). Proportionality would apply.

251. Denmark's laws also make provision for the seizure of objects and assets in third party hands to secure a confiscation order. Objects are subject to seizure in the course of an investigation if can reasonably be 
presumed that the they should be confiscated or forfeited. Value confiscation can also be secured through assets in third party hands. Under section $803(2)$, assets such as money may be seized under the same standard: if it can be reasonably presumed that such assets may be confiscated or forfeited.

252. Generally, a decision on seizure is made by the court (section 806(2) AJA) but the police may also carry out a preliminary seizure if awaiting a court order will defeat the purpose of the measure. In such a circumstance, the police must either obtain consent or bring the matter before a court within 24 hours at the request of the affected person. Section 806(3)). A seizure must be proportional. If less invasive measures would be effective, they must be used. (See section 805). Seizure orders may issue without prior notice. Section 748(1) of the AJA provides that suspects need not be informed of court hearings for orders relating to discovery, search and seizure or other preliminary matters (matters arising under Chapters 69-74 of the AJA). As a matter of practice, notice is not normally provided, with authorities providing such information only in circumstances when it would not adversely affect the seizure. The court or police may bind a person not a suspect to secrecy regarding a seizure, production or questioning if necessary in a criminal investigation. (Sections 189, 803 (1) and 804 (2) AJA.)

253. A Circular addresses the management of seized proceeds. Cash in amounts that exceed DKK 2,000 (EUR 268) and securities must be deposited in a bank or other financial institution. In the case of immovable property, seizures are to be registered in official title registries to prevent owners from selling or otherwise disposing of the property.

\section{$\underline{\text { Searches }}$}

254. Searches (of dwellings, other premises or objects that a suspect possesses) for seizable property may occur only if the person is reasonably suspected of an offence indictable in Denmark and the search is of significant importance to the investigation. The same kind of searches where the person is not a suspect may take place upon consent or if there is an investigation of an offence for which imprisonment can result and there are specific reasons to presume objects which can be seized can be found by the search. A decision to search in the case of a suspect is made by the police; decisions with respect to others are made by the court except in exigent circumstances. (Section 796 (1) and (2) AJA).

255. A court may permit the police, with a single warrant, to carry out several individual searches without immediate notification (repeated secret searches) within a period not exceeding four weeks. This may be necessary where, for example, no drugs or weapons were found at the first search, but where it is still suspected that delivery on the location in question will take place within a short time, or where a search had to be interrupted owing to the risk of discovery of the investigation.

Freezing/restraint

256. Danish authorities indicated that as a matter of practice, law enforcement authorities always seek to either restrain or seize criminal proceeds as soon as proceeds or substitute assets are located. Restraints are included under the concept of seizure under Danish law (see AJA Sections 801 et. seq.) and when a seizure takes place, the authorities may either take possession of the property or leave it restrained in another's hands.

\section{Production Orders and Tracing Mechanisms}

257. In the early states of a criminal investigation, Danish law enforcement authorities routinely investigate the proceeds and benefits from criminal activity. Police and prosecutors are provided with investigative powers that permit identification and tracing of assets, including powers to order production of documents, to search and seize, and as needed in cases of aggravated ML or FT to use various special investigative techniques. They have ready access to various sources of domestic information including information held by tax and customs authorities, and can access public databases as companies registers, real estate registers, and vehicle register. 
258. Production of documents (for instance financial records) by third parties is provided for through section 804 of the AJA. As long as an item can serve as evidence or may be confiscated, an order may issue. Danish authorities indicated that serving as evidence includes the concept of any material that provides information about the criminal conduct. Production orders typically do not include time limits for production and authorities may alternatively conduct a search and seizure if there are indications that material will not be available as needed. However, financial institutions comply within time frames that are worked out with the authorities.

259. Customer information orders which require the provision of information on whether a person holds an account and basic account details are handled through a production order directed to all banks and distributed through the Bankers Association. Once the results show the target is a customer at a specific bank, the police seek a production order directed to the specific bank. Monitoring orders that require financial institutions to monitor ongoing account activities in an identified account for a specified time period may also issue as needed.

260. As a general rule, seizure/production orders issued by a court are required in order to gather information from a financial institution, but as noted above if seeking such a order would adversely affect the proceeding, the police can seize/order production and, if so requested by the third party, have the matter brought before the court within the 24 hour period after production/seizure. (Section 806(3) AJA). Foreign exchange offices and money transmitters generally make information available without a production order.

Authority to void actions

261. The courts may take steps to prevent or void actions in the nature of legal arrangements devised to defeat recovery of proceeds. Danish courts have invalidated such arrangements on a number of occasions where pro forma sales or transfers of assets took place. Under Danish law, the assets of a perpetrator that may be confiscated include any assets that he has, in reality, control over. In some cases the sale of shares to a dummy entity or the transfer of assets to a company have been declared void or pro forma by the courts. In addition, because of liberal provisions on third party confiscation, authorities have found that they do not often have to go beyond applying these provisions. Voiding may take place however in situations where payment is said to have taken place but where this cannot be proved or when documents regarding a transfer are antedated to a time before the offence.

\section{$\underline{\text { Additional elements }}$}

262. In Denmark, the property of organizations found to be primarily criminal in nature (where the principal function of the organization is to engage in illegal activity) is addressed through the dissolution of the organization by court judgment. Associations formed or that later operate for unlawful purposes may be dissolved. Once dissolved, the association's assets are subject to confiscation under section 75(5) of the Criminal Code. In addition, the property of an organization can be seized and confiscated if the requirements for third party confiscation are met. In assessing whether an association is operating in an unlawful manner, consideration is given to whether the association works through illegal means including terrorist acts. Associations may be temporarily prohibited by the government, but a dissolution is through the judgment of a court. See, section 684 (1), no. 2, of the AJA. Authorities report that there have not been cases of dissolution of criminal organizations in Denmark.

263. Denmark does not have a system of civil confiscation and has not viewed it as necessary. Recognizing that other States have adopted and actively use such systems, authorities are, on an ongoing basis, evaluating whether it would be useful and would likely improve the effectiveness of the Danish system. However, Denmark has provisions for preventive confiscation and confiscation can occur even when the conduct producing proceeds is not attributable to a particular perpetrator.

Greenland and Faroe Islands 
264. Greenland and the Faroe Islands have a capacity to trace, seize and confiscate but the provisions are not as extensive or updated as those that apply in Denmark. The provisions in these jurisdictions were not reviewed by the evaluation team. Danish authorities indicated that both Greenland and the Faroe Islands have provisions that are similar to those in Denmark before the 2002 Anti-Terrorism Act which, among other things, added a provision in the Criminal Code, Section 77a, that permits a kind of preventive confiscation useful in terrorism settings. In Greenland, provisions appear in Section 116-119 of the Criminal Code and search, seizure and tracing provisions appear in the Greenlandic Administration of Justice Act, Chapter 5, Sections 8-9, 9a-9d, and 10-12. Authorities in Denmark note that work has been initiated to bring the Greenlandic and Faroese provisions on tracing, seizure and confiscation up to the same level as those in Denmark.

\section{$\underline{\text { Statistics }}$}

265. Denmark maintains some limited statistics regarding property confiscated as set forth below. However, authorities indicated there were no easily retrievable statistics on property frozen or seized, or the amounts of such property that are ultimately confiscated. Moreover, information on the exact number and type of criminal cases in which confiscation was imposed is not available. Confiscation statistics are not maintained by criminal activity. Accordingly, there is no information of amounts confiscated separately for ML cases or any other type of offence. Based upon reports from the 54 police districts, the following, as to which Danish authorities indicated there was uncertainty, are the approximate total amounts confiscated in the years set forth:

200125.0 million DKK (EUR 3,4 million)

200228.5 million DKK (EUR 3.8 million)

200343.0 million DKK (EUR 5.8 million)

200460.5 million DKK (EUR 8.1 million)

200572.9 million DKK (EUR 9.8 million)

266. Specifically regarding the above figures, no information is available on the number of cases to which they relate and only anecdotal information on the types of cases. Danish authorities indicated that they believed most of the amounts relate to a handful of cases involving drug trafficking or economic crime.

267. Danish authorities also noted that for the 122 individuals who were convicted (or otherwise had fines or administrative decisions imposed) in cases that arose from STR reports for the eleven year period 1994-2005, DKK 199.4 million (EUR 26.7 million) was either retrieved or the subject of a court order that imposed confiscation or supplementary fine. These figures do not indicate amounts actually recovered as some orders to pay may not have been executable.

268. In addition to the amounts confiscated, proceeds are also recovered through compensation to victims, repayment and supplementary fines (which as noted are used as an alternative to confiscation in some instances).

\section{Effectiveness}

269. With respect to effectiveness of implementation, the evaluation team did not consider that the authorities were able to establish that they had been fully effective in the task of actually recovering proceeds generated by criminal conduct actionable in Denmark. Denmark has thus far maintained only the bare statistics noted above which indicate gross amounts reflected in orders of confiscation. The authorities indicated there was a great deal of uncertainty surrounding the statistics, and that the statistics provided reflected not amounts recovered but amounts imposed. Nor did the figures provided reveal numbers of cases or relate to specific kinds of criminal activity. Finally, authorities indicated the major parts of the gross amounts provided reflected 
amounts imposed in a few large drug trafficking and economic crime cases.

\section{Recommendations and comments}

270. Authorities should evaluate on a regular basis their use of their comprehensive tracing powers, and seizure and confiscation provisions to determine whether they are being used effectively to recover proceeds. In connection with this, there should be a review of amounts confiscated, supplementary fines recovered and victim compensation paid (and the number of cases in which this occurs), as well as levels of success in tracing proceeds from proceeds generating crimes and in seizing early in a proceeding to secure final orders.

271. Authorities should gather meaningful statistics and use them in reviewing effectiveness.

272. Greenland and the Faroe Islands appear as reservations with respect to the Kingdom of Denmark's ratification of the Vienna and Palermo Conventions. Authorities should proceed with putting into place any missing the legal and practical requisites for tracing, seizing and confiscating proceeds in all cases, work that authorities indicate has already been initiated.

273. While quite comprehensive and robust in many respects, Denmark's confiscation scheme lacks a provision for the continuation of confiscation proceedings in the case of an absconding defendant. Authorities should consider such a provision.

\begin{tabular}{|l|l|ll|}
\hline \multicolumn{2}{|c|}{ Compliance with FATF Recommendations } \\
\hline R.3 & LC & $\begin{array}{l}\text { Summary of factors underlying rating } \\
\text { Given the lack of meaningful data and regular review of confiscation and } \\
\text { tracing efforts/accomplishments in Denmark, the tracing, seizure and } \\
\text { confiscation provisions were not shown to have been fully implemented. }\end{array}$ \\
$\begin{array}{l}\text { Work is not yet complete on updating Greenlandic and Faroese provisions } \\
\text { on tracing, seizure and confiscation. }\end{array}$
\end{tabular}

\subsection{Freezing of funds used for terrorist financing (SR.III \& R.32)}

\section{Description and analysis}

274. Under SR III, countries should have laws and other procedures in place to freeze terrorist funds and other assets of persons designated pursuant to the applicable United Nations Resolutions S/RES/1267 or S/RES/1373. For persons and entities designated on the UN list pursuant to S/RES/1267 and for externally based persons and entities designated through the EU process for S/RES/1373 designations, Denmark has implemented measures to freeze terrorist funds and other assets through directly applicable EU instruments. In all other situations, it uses its seizure powers under its AJA. This kind of seizure takes place in connection with a criminal investigation opened on the basis of information received from another jurisdiction or because of a STR filed in relation to a person not on either of the lists.

\section{$\underline{\text { S/RES/ } 1267 \text { and } 1373}$}

275. Denmark's framework for implementation of the financing of terrorism aspects S/RES/1267 and subsequent resolutions in the sanctions regime against Al Qaida/Taleban is through EC Regulation 881/2002. Under general European law principles, EU regulations are directly applicable in European national systems (EU member countries) as Denmark without the need for domestic implementing legislation. As such EC regulation $881 / 2002$ serves as statutory law in Denmark. Under the regulation, all funds and economic resources belonging to, or owned or held by a natural or legal person, group or entity designated by the Sanctions Committee and listed in the annex of the regulation shall be frozen. Under EU guidelines, the European Commission updates 
Regulation $881 / 2002$ every time a change is made to the UN list, if possible within three working days of the UN list change. Denmark has designated the National Agency for Enterprise and Construction (NAEC) as the competent authority under this EU regulation as well as the EU regulation relating to S/RES/1373.

276. Implementation of the financing of terrorism aspects of S/RES/1373 is through EU common position 2001/931/CSFP and EC Regulation 2580/2001. The Council acting in unanimity determines additions to the list of terrorists and terrorist organizations that is attached to Common Position 2001/931. Externally based terrorists or terrorist organization (non EU-based entities or non EU residents or citizens known as "EU externals") are also covered by Regulation 2580/2001, and are concurrently added to a list attached to the regulation. Financial institutions and others are required to directly implement Regulation 2580/2001 by freezing the assets without delay of the designated persons and entities without prior notice. For persons and entities to which only Common Position 2001/931/CFSP (but not Regulation 2580/2001) applies (EU internals), there is no directly applicable requirement for the freezing of assets. However, all persons and entities that appear on the list attached to Common Position 2001/931 are subjects for increased police and judicial cooperation.

277. Financial institutions and others are required to directly implement EC Regulations 881/2002 and $2580 / 2001$. When additions to the attached lists are published, financial institutions and others who identify a customer whose name is on one of the lists are required to immediately freeze the account or property. Funds should be frozen without prior notification to the persons concerned. Upon freezing, financial institutions and others must notify the National Agency for Enterprise and Construction (NAEC) or the SØK that they have frozen funds. In accordance with the EU regulations, NAEC or SØK is then to report this information to the Commission. NAEC provides written instruction on who to notify, how notification should occur, and the kind of information that should be forwarded in a letter that accompanies the information NAEC distributes to financial institutions and others each time there is an amendment to Regulation 881/2002 or 2580/2001. Assets to be frozen include those owned wholly or jointly as well as those controlled. While the EU Regulation is not explicit on the point of joint ownership, (rather implicitly recognizing that joint ownership is a form of ownership), the EU Best Practice of 29 November 2005 relating to Restrictive Measures, which Danish authorities are prepared to follow, provides that "funds and economic resources jointly owned by a designated person or entity and a non-designated one are in practice covered in their entirety. The non-designated person or entity may subsequently request an authorization to use such funds and economic resources, which may include severing the joint ownership so that person's share can be unfrozen."

278. Any freezing (whether pursuant to EC Regulation 881/2002 or 2580/2001) remains in effect until otherwise decided by the EU. No court hearing is required for the freezing to take place and to remain in place. A person or entity whose funds are frozen may always apply to the NAEC for an exemption. This is provided for through the EU regulations. If NAEC, after consultation with the MFA and SØK, decides to refuse the request, the applicant can decide to have the matter presented to a national Danish court. If the challenge is to the legality of a designation under the regulations, the European Court of Justice can hear the complaint if made within two months after the designation. If the legality of a designation is lodged before a Danish court, the court can present this question as a prejudicial question to the European Court of Justice.

279. If the claim is that the freeze is not justified because of mistaken identity, the NAEC will review the case and consult with the MFA and SØK, and if necessary with the EU Council or the UN Sanctions Committee. If the NAEC determines the claim is justified, the freeze will be lifted immediately. In addition, the financial sector as well as other EU Member States and the EU Commission will be informed in order to avoid unjustified freezing in other states.

280. There are no pending freezes of funds or assets in Denmark pursuant to UN/EU listings, nor have any taken place in the past. In many instances, financial institutions have made inquiries to the SØK based upon a potential name match but in each instance the SØK in consultation with appropriate authorities has determined that the account was not that of a person/entity on the list. The FIU treats these inquiries as STRs and there have been over 200 in the period from September 2001 through the end of 2005. 


\begin{abstract}
281. For the lists of persons and entities designated for freezing purposes through the EU regulations, Denmark has a full capacity to freeze funds in accordance with S/RES/1267 and S/RES/1373 directly through the EU regulation mechanisms. For persons and entities not on lists for which freezing is required, both EU internals (covered by Common Position 2001/931 but not Regulation 2580/2001) and persons and entities who do not appear on any lists, but for which Denmark receives a direct freezing request from other jurisdictions, as well as circumstances where a freeze is necessary because of other information that indicates a possibility of financing of terrorism (e.g. information received through a STR), the EU regime for freezing is unavailable. In such circumstances, Denmark has a court based mechanism for seizure and confiscation of terrorist funds. See the description of that mechanism under the section below.
\end{abstract}

\title{
Freezing, Seizing in other circumstances
}

282. For the freezing of assets of EU internals (to which Common Position 2001/931 but not Regulation 2580/2001 applies) and persons and entities who do not appear on any lists, but for which Denmark receives a direct freezing request from another jurisdiction, as well as circumstances where a freeze is necessary because of other information that indicates a possibility of financing of terrorism (e.g. information received through a STR) the same procedures apply. In these cases the revised and updated mechanisms under the provisions of the Danish Criminal Code and criminal procedure law are utilized. These mechanisms, with one exception appear to meet the requirements of obligations imposed by S/RES/1373. Denmark amended its Criminal Code in 2002 through the Anti-Terrorism Act of June 2002 to ensure that seizures and confiscation could reach fully terrorist assets. Both Sections 802 and 803 of the AJA (for seizures) and Section 77a of the Criminal Code (for confiscation) were amended to extend their scope to money and other property and not just objects.

283. In its current form, Section 77a of the Criminal Code provides for preventive confiscation of any assets, including funds and objects, which may be applied to commit crimes. In addition, seizures (which include in Denmark the concept of freezing) are authorized under Section 801-806 of the AJA on the basis that there are reasonable grounds to suspect an individual committed an offence and seizure is necessary to secure evidence or the claim for confiscation (including preventive confiscation)

284. Authorities indicate that the seizure would take place on an immediate basis both because of the obligation of the institution to freeze (which applies even when there is a suspicion relating to a person not on the list) and because police in exigent circumstances can issue a seizure order and seek approval thereafter (see section 806(3) of the AJA). In addition, the reasonable grounds standard equates with the reasonable basis, which a foreign authority is to submit. In these circumstances, funds collected that may be used to finance terrorism may be seized and confiscated.

285. However there is not a basis for (nor policy in favor of) seizing funds collected/received, etc. to support terrorists or terrorist organizations for non-terrorism related activities. This is unlike the funds frozen pursuant to the EU regulations, which call for the freezing of all funds and other assets belonging to persons or entities on the list and a prohibition on making assets available to such persons regardless of the purpose for which they may be used. Using these alternate procedures, Denmark may thus not freeze all funds and assets of persons who commit or attempt to commit or participate in or facilitate the commission of terrorist acts, but only those funds that will be used for terrorism purposes.

286. Danish authorities explained that they view the freezing requirements of S/RES/1373 (2001) as covering only assets that will be used in one way or another for terrorism purposes, and would not act to freeze assets for other purposes outside of the obligations with respect to persons who have been listed for whom the wider obligation is applied. They believe that Article 1(c) of S/RES/1373 must be read in the context of Article 8 of the Terrorist Financing Convention which requires measures to identify, detect, freeze or seize "any funds used or allocated for the purpose of committing [a terrorist act]. The Danish view is that the condition of a connection to a terrorist act must be taken into account in interpreting Article 1(c) of S/RES/ 1373. They state that outside situations where there is a direct legal basis in a UN Resolution or EU regulation, freezing assets that are beyond those that might in one way or another be used for terrorism purposes might conflict with the Danish Constitution or the European Convention for the Protection of Human Rights and Fundamental Freedoms. They 
believe their interpretation is consistent with the principles on the law of property set forth in Section 73 of the Danish Constitution and the first Additional Protocol to the European Convention for the Protection of Human Rights.

287. S/RES/1373 requires under Section 1(c) that nations freeze "funds, and other financial assets or economic resources of persons who commit or attempt to commit, terrorist acts or participate in or facilitate the commission of terrorist acts....". SRIII sets forth the standard that there be measures to freeze without delay funds or other assets of terrorists, those who finance terrorism and terrorist organizations in accordance with the UN Resolutions. Although Danish authorities have a different view, the resolution appears to go further than the Terrorist Financing Convention with a requirement that all resources of those who participate in or facilitate the commission of a terrorist act (including by collecting or providing funds), not merely funds that are intended for use in the commission of the crime be frozen.

288. With respect to the obligation to act without delay, as noted the procedures for seizure (freezing) under Danish law provide for such actions to take place in exigent circumstances without a court order. Prosecutors may thereafter seek and receive the order. Accordingly a call to a financial institution by police authorities is sufficient. In addition, if a matter arises through a STR, under section 7(4) of Denmark's MLA, the filing party must not carry out the transaction without the consent of SØK.

289. Regardless of whether there is a freeze occurring by operation of an EU regulation or a seizure through the criminal processes, there is no prior notice to the holder of the asset. See sections 748 (1) and (6) and 189(1) of the AJA. In addition, as noted above, the freeze may apply to assets wholly or jointly owned or controlled as well as funds derived or generated from such assets. This is provided for in the EU context through the regulations and best practices and also permitted under seizure and confiscation provisions of Danish domestic law. Danish courts in other settings have addressed control and looked to the underlying reality.

290. The MFA co-ordinates Danish positions regarding EU designations. While there are not formal processes in place to have all interested parties, including MOJ (including the SØK and Danish Security Intelligence Service) consider whether to support a request for a designation, authorities indicate that there is close cooperation between these authorities on financing of terrorism matters and the relevant parties would formulate a request for a designation through the building of a case by SØK in consultation with the Danish Security Intelligence Service which would then be forwarded through the MOJ to the MFA. Because of urgency and the priority given to such matters, this could occur quickly once it appeared a designation was appropriate.

$\underline{\text { Communication and guidance to Financial Institutions and other potential stake holders }}$

291. With respect to communication and guidance, Denmark relies in large part on the EU regulations itself to guide financial institutions and others. The EU regulations have direct applicability to all EU entities and persons including those in Denmark and there is a related obligation of Denmark's citizens and residents to know and act in accordance with the law. The EU regulations list the contact point in Denmark as the NAEC. The NAEC has taken steps to ensure many affected persons (those that must take the freezing action) are actually informed on a timely basis, but particularly for some sectors as noted below, there were not at the time of the mission regular and effective steps to provide guidance or to ensure actual notification.

292. EU legislation, including amendments to the lists pursuant to the Regulations implementing $\mathrm{S} / \mathrm{RES} / 1267$ and S/RES/1373, is made public in the official journal of the EU (accessible through the Internet) and is thereby binding as law on Danish financial institutions and other entities and persons. The Sanctions Division at the European Commission usually also notifies Member States through an email before an amended list is published. This amended list as well as the early notification is emailed both to NAEC and to SØK.

293. Denmark has a good system in place to distribute updates to both UN and EU lists and does not rely solely on institutions and others accessing updates to the publication in EU's Official Journal. Rather NAEC 
distributes such lists directly to a wide range of trade and industry associations and government bodies. Authorities noted the distribution as an information service and not a legal requirement.

294. When distributing the updates to financial institutions and associations, the NAEC recommends that they should undertake a subsequent distribution to their members. Among the associations outside the financial sector to whom the lists are distributed are the Danish Shipowners Association, the Danish Chamber of Commerce (for Trade, Industry and Service), the Bar and Law Society and the Danish Fund Raising Association. Within government, the lists are distributed, among others, to the Danish Commerce and Company Agency, the Financial Supervisory Authority, the Central Bank, SØK and the Foreign Ministry. For this distribution, it would be helpful for it to also cover real estate agents and brokers. Authorities undertook to do this on a post-mission basis. Danish authorities noted that as NAEC is distributing lists simply to provide information regarding a matter that Danish persons and entities have an obligation to maintain awareness, NAEC does not follow up on how quickly lists are disseminated by these organizations and is not specifically aware whether associations actually distribute the lists other than with respect to the banking industry. In addition, the EU has an electronic database that has all designees covered by all EU regulations on financial sanctions that is generally available.

295. With the exception of the distribution of the lists to associations most of which represent financial institutions of one kind or another, there are no specific measures to ensure that persons who hold assets are informed of the listings. For instance, tangible or real property may be held or registered in the name of a listed person, yet checks are not apparently routinely made and appropriate action taken to ensure the property is actually encumbered. In particular, although law enforcement officials check listed names against various databases, it does not appear there is a routine check of property ownership registers (for instance real estate and ships) to determine whether a named individual or organization holds property in Denmark and action taken to encumber property. There should also be notification to those who are involved in real estate and vessel purchases and transfers. Authorities are considering whether it would be useful to conduct more outreach and awareness training regarding the lists particularly outside the financial sector.

296. In addition Denmark's Ministry of Foreign Affairs distributes all changes made to the UN list as soon as the Ministry is notified by email by the Al Qaida/Taleban Sanctions Committee. This notification goes to a number of agencies, including NAEC and to SØK.

297. Lists of terrorists and terrorist organizations from other jurisdictions are received by the FIU or the MFA. The FIU distributes these lists (assuming that the sending agency is in agreement) immediately to the Banker's Association so that banks can review their customer lists and send STRs as appropriate. There must be a special effort regarding these lists, which unlike others, are not available publicly (on EU web-sites, etc.) to ensure they are fully and carefully disseminated and receive dissemination beyond banking institutions.

298. Danish authorities have have produced some practical written guidance for the financial sector and designated non-financial businesses and professions and others that may be holding funds or other assets concerning their obligations under the freezing regime and procedures to address the lists. As noted, the NAEC provides written instruction on who and how to notify and the kind of information needed in the letter that accompanies the distribution of information to financial institutions and others on amendments to Regulations 881/2002 and 2580/2001.In addition the NAEC provides in an introductory letter to all new parties background information on these regulations, information on cooperation between authorities and what to do in stituations of name and identity matches including links to relevant web pages. However, an underscoring of the obligation to promptly check listed names against account and customer lists, etc.), information on procedures for exceptions to the freezing rules for humanitarian reasons, for delisting and the like would be helpful particularly for institutions other than banks that have less experience in handling lists. Even though the EU, in addition to issuing the two EU regulations, which identify basic obligations, has issued a Best Practices Guide that sets forth procedures for Member States to follow, it does not contain practical advice for responding institutions and persons within a national framework. It would be helpful for there to be written guidance that explains procedures and obligations so that all Danish entities are aware, on a practical level, of how these matters are to be handled within Denmark. 
Procedures for delisting and unfreezing

299. Denmark has no Danish citizens or residents who are listed, or who have previously been listed, in the EU lists related to UN Resolutions S/RES/1267 and S/RES/1373. Accordingly, on a practical level, it has not had to address de-listing. In addition, there have not been freezes of funds of persons listed in the EU lists. There are however applicable procedures should de-listing or unfreezing be required in the future. Relevant European regulations do not provide for a national autonomous decision regarding de-listing and unfreezing as a whole.

300. Requests for de-listing from the list of persons and entities comprised by the UN sanctions against Al Qaida and the Taleban (the UN list) and the list of persons and entities comprised by the restrictive measures in EU Common Position 931/2001/CFSP (the EU list) are to be directed to the MFA. If a request is filed with another Danish public authority, e.g. the MOJ or the Agency for Enterprises and Construction, this authority should redirect the request to the MFA with a view to obtaining a coordinated Danish position. Danish authorities have not so far received any requests for de-listing from the UN or the EU lists.

301. If a request for de-listing relates to the UN list, the procedure for de-listing is that laid down in the $\mathrm{Al}$ Qaida/Taleban Sanctions Committee guidelines. As a first step the MFA will determine if the petitioner is a Danish citizen or resident. If this is not the case the petitioner will be instructed to file the request to the government of citizenship or residence. If the petitioner is a Danish citizen or resident, the Ministry will review all relevant information (in co-operation with other relevant Danish ministries/agencies, e.g. the Security Intelligence Service and the Defence Intelligence Service) and approach bilaterally the government(s) originally proposing designation to seek additional information and to hold consultations on the de-listing request. If needed, consultations will also be arranged with the Chairman of the Al Qaida/Taleban Sanctions Committee. If the Danish Government after having reviewed all relevant information wishes to pursue the de-listing request, it will seek to persuade the designating government(s) to submit jointly or separately a request for de-listing to the Al Qaida/Taleban Sanctions Committee. If the designating governments(s) do not wish to submit a joint or separate request, and the Danish Government still wishes to pursue the matter, a separate Danish request for delisting will be submitted to the Al Qaida/Taleban Sanctions Committee. Should the Sanctions Committee de-list, there is a corresponding de-listing by the EU Council in its Regulation 881/2002 and the result is an immediate unfreezing of assets.

302. If a request for de-listing relates to the EU list, the MFA will review all relevant information (in cooperation with other relevant Danish ministries/agencies, e.g. the Security Intelligence Service and the Defence Intelligence Service) and approach bilaterally the government originally proposing designation to seek additional information and to hold consultations on the de-listing request. It is noted that all listed persons and entities can petition any EU member country with a request for de-listing. If the Danish Government after having reviewed all relevant information wishes to pursue the de-listing request, the MFA will strive to convince other EU Council members about the legitimacy of the de-listing request.

303. Delisting matters may also be pursued before the Danish and EU courts.

304. Unfreezing in the case of mistaken identity may take place in the Danish system in accordance with the EU Best Practices paper ("Effective Implementation of Financial Restrictive Measures targeting Terrorist Persons, Groups or Entities"), that is, a person may have his case considered by the NAEC which serves as the Danish competent authority. The NAEC may conclude that the freeze should be lifted after verification that the person or entity is not the designated person. If it cannot come to a conclusion, and advise the financial institution or other entity of its conclusion, the party is free to follow the procedures available that protect third party interests. To avoid unjustified freezings in the first place, Denmark has financial institutions report names as to which there might be some question to the NAEC or SØK. These are reviewed immediately by SØK and the Danish Security Intelligence Service and they provide advice regarding the necessity of an immediate freeze. If the agencies decide there may be a match, assets are frozen while the identity question is clarified. In the case 
of seizures that take place relating to EU nationals or other non-designated persons, Danish courts have jurisdiction to hear such matters. Where a freeze occurs pursuant to a bi-lateral request, as a domestic court based mechanism is used for the freeze, the procedure for unfreezing is through the request of the appropriate authority or affected person to authorities in Denmark to lift the freeze.

\section{Bona Fide Third Parties}

305. The usual protections under Danish law to the rights of bona fide third parties are applicable in the case of freezing under the EU lists or a seizure otherwise ordered in the Danish system. Specifically, there is access to the courts in Denmark to challenge aspects of a freeze that adversely affects a person or entity. The court could in turn seek the advice of the European Court of Justice. In addition, if the freeze is imposed through Regulation $881 / 2002$ or $2580 / 2001$, persons or entities may institute proceedings before the European Court of Justice which is invested with authority to review the legality of such freezes. EC regulation 881/2002 at Article 6 also protects the good faith actions of freezing entities except when a freeze is due to negligence. This provision is directly applicable in Denmark.

Monitoring compliance

306. Denmark's MLA imposes a reporting obligation on institutions and undertakings to report suspicions of the financing of terrorism whether that suspicion is based upon the appearance of a name upon a list or upon other independent grounds and provides for monitoring of compliance with various obligations including an obligation to review complex, unusual large transactions and unusual patterns of transactions with no apparent economic or visible lawful purpose, as well as for the maintenance of appropriate systems.

307. For financial institutions, the FSA has responsibility for ensuring compliance with obligations under the act and covers systems to comply with reporting under the UN resolutions/EU Regulations as part of its inspection process. For other sectors, the agency with supervisory responsibility under the above act also has responsibility for ensuring compliance with the obligation. In each instance, the same sanctions as for noncompliance with the general reporting and other obligations apply. See, Section 3.10 (financial institutions) and 4.4 (non-financial businesses and persons). Separately and in addition, a violation of the EU regulation is punishable under the Danish Criminal Code, Section 110c(3). Under that provision, persons who contravene specified EU regulations are liable to a fine or imprisonment for a term of four months, or in aggravating circumstances, to a term of four years.

308. On a practical level, financial institutions noted that they have reported to the FIU regarding possible name matches on a number of occasions and have awaited further instruction, but have not always received feedback from the FIU indicating on a positive basis that the account holder was not a match. Under Section 7-4 of the MLA, if an undertaking covered by the Act (as a financial institution) has a suspicion relating to the financing of terrorism, transactions in the account or from the person under suspicion may only be carried out with the consent of the Public Prosecutor who must decide by the end of the day following receipt of the notification whether seizure is to be effected. It is important that the Public Prosecutor notify banks and other institutions when they have provided notification of a possible name match on a timely basis whether they may proceed with transactions on the account.

\section{Access to funds for expenses}

309. S/RES/1452 is implemented in the EU through a new Article 2a in EC Regulation 881/2002 that authorizes access to funds that are frozen for basic expenses, certain fees or for extraordinary expenses. The Danish competent authority that is to receive requests for exemptions is the NAEC which determines if the request merits action. If so, the request is addressed to the Al-Qaida/Taleban sanctions Committee. A procedure is also envisioned in Article 5 and 6 of EC Regulation 2580/2001 which relates to designations emanating from $\mathrm{S} / \mathrm{RES} / 1373$. The NAEC may grant a specific authorization to unfreeze funds for essential human needs under such conditions as it deems appropriate and under Best Practices coordinate such matters with other member 
States. These procedures have not been employed in Denmark as there have been no freezes pursuant to the EU/UN lists.

Greenland and Faroe Islands

310. Greenland and the Faroe Islands would use their domestic provisions on seizure to effect a freeze under UN resolutions. An ability to fully comply with the UN resolutions, for these jurisdictions neither of which are members of the EU (and therefore to which the directly applicable EU regulations would not apply), is dependant upon a legal framework that provides for full criminalization of terrorist financing together with a legal provisions for provisional measures that would ensure immediate freezes in appropriate settings (see discussion above of the measures applicable in Denmark.) Finally, there do not appear yet to be practical arrangements in place to ensure that the resolutions will always be appropriately applied, persons notified, etc. although there is ongoing dialogue on the division of internal responsibilities between Denmark and these jurisdictions in a number of areas including UN Resolution implementation.

\section{$\underline{\text { Additional elements }}$}

311. A pre-notification system of upcoming designations is in place within the EU to ensure that simultaneous actions can be taken by States in order to freeze terrorists' assets. Denmark is able to share information with other countries and would, if it became applicable, be able to make public amounts frozen pursuant to orders.

\section{$\underline{\text { Statistics }}$}

312. Danish authorities are prepared to keep statistics on the number of persons entities having property frozen pursuant to UN Resolutions and the amounts. The NAEC is to be advised of any freezes relating to those on UN/EU lists and SØK will have information regarding freezes based upon use of domestic mechanisms. Thus far, as there have been no relevant freezes, there are no statistics or amounts.

\section{Recommendations and comments}


313. Danish authorities should be prepared in accordance with UNSCR 1373, Article 1(c) and SR III in every case to freeze all assets of terrorists and terrorist organization (not only those that may be used for terrorist purposes) and not limit a freeze of all assets to situations when there is a directly applicable freeze through EU regulations.

314. Danish authorities should provide additional written guidance to the financial sector and designated non-financial businesses and professions and others that may be holding funds or other assets about the practical aspects of their obligations under the freezing regime. procedures for access to funds and the de-freezing processes.

315. Greenland and Faroe Islands should adopt legal provisions and implementation measures to facilitate compliance with the UN Resolutions.

316. The FIU should undertake additional efforts to ensure that all appropriate institutions and persons receive notice regarding lists forwarded by countries and not publicly available.

317. Authorities should ensure institutions making inquiries about possible name matches receive prompt feedback.

318. Although law enforcement officials check listed names against various data-bases, in addition, property ownership registers (for instance real estate and ships) should be reviewed to determine whether a listed individual or organization holds property in Denmark, and the property encumbered.

319. Danish authorities should distribute lists to property transfer agents as real estate agents and brokers. Authorities indicated that post-mission, this has been undertaken.

\section{Compliance with FATF Recommendations}

\begin{tabular}{|l|l|ll|}
\hline SR.III & PC & $\begin{array}{c}\text { Summary of factors underlying rating } \\
\text { - }\end{array}$ & $\begin{array}{l}\text { In contrast to freezes related to EU regulations, authorities are not } \\
\text { prepared under their domestic framework to freeze non-terrorism related } \\
\text { assets of terrorists and terrorist organizations. }\end{array}$ \\
$\begin{array}{l}\text { Denmark could further improve practical guidance to institutions or other } \\
\text { persons or entities that may be holding funds or other assets concerning } \\
\text { obligations and procedures including those to authorize access to funds. }\end{array}$ \\
$\begin{array}{l}\text { In the case of Greenland and Faroe Islands, to which the EU Regulations } \\
881 / 2002 \text { and } 2580 / 2001 \text { do not apply, all the necessary legal and practical } \\
\text { arrangements to enable the jurisdictions to comply in each instance with } \\
\text { the freeze requirements of relevant UN resolutions are not in place. }\end{array}$ \\
$\begin{array}{l}\text { Procedures for dissemination of lists forwarded by countries are not } \\
\text { sufficient to ensure all institutions and others have notice. }\end{array}$ \\
Institutions have not always received feedback regarding possible name \\
matches.
\end{tabular}

\section{Authorities}




\subsection{The Financial Intelligence Unit (FIU) and its functions (R.26, 30 \& 32)}

\section{Description and analysis}

320. The Denmark FIU, known as the Money Laundering Secretariat, is located within the Office of Public Prosecution for Serious Economic Crime which is part of the Public Prosecution Department, under the direct control of the MOJ. The Office of Public Prosecution for Serious Economic Crime is responsible for the investigation and prosecution of serious economic crime, including money laundering and the financing of terrorism, for the nation as a whole. The Office of Public Prosecution for Serious Economic Crime comprises two investigation sections, a legal secretariat (of which the FIU is part), an administrative section, an investigation support section which provides police support to investigation of economic crimes and two small staff sections for IT and technical support. The AML Secretariat staff consists of prosecutors (3), police officers (7) and administrative staff (1).

321. The FIU is not expressly created by law and was established by Circular Letter of June $1993^{6}$ (under the previous law) following a decision of the Minister of Justice to the effect that all violations of the AML legislation shall be investigated and prosecuted by the Money Laundering Secretariat of the Office of Public Prosecution for Serious Economic Crime. The Circular Letter provides that the FIU shall be the agency responsible to "collect, register, disseminate, coordinate and process" suspicious transactions regarding money laundering. Although there is no reference in the Circular Letter to the financing of terrorism, the express reference in the Circular Letter to the 1993 Act (as subsequently modified) is sufficient indication of the FIU mandate, and constitutes the legal basis for the FIU, to receive, analyze and disseminate reports of suspicious transactions that may be associated with both money laundering and the financing of terrorism.

322. In this respect the Act on Measures to Prevent Money Laundering and the Financing of Terrorism $2006^{7}$, which came into effect on the $1^{\text {st }}$ March 2006, repealing the $1993 \mathrm{Act}^{8}$, confirms the obligation to report any suspicious transaction that may be associated with money laundering or the financing of terrorism (with the exception of casinos, which, under a separate act, are required to report to the Police), to the Office of Public Prosecution for Serious Economic Crime (for the case of Casinos, which report directly to the Police, see the analysis under Recommendation 16). The circular letter clarifies that the STRs under the MLA are to be sent to the ML Secretariat. STRs are received by either in the form of a letter from the reporting authorities or by telefax, not in an electronic format.

323. In urgent cases reporting institutions are allowed to inform directly the local police. The circular letter says that "in these cases the ML Secretariat will be only informed of to which police district the disclosure was sent and which person/company it concerned. Further information will be then obtained from the Police district. The authorities described these situations as referring not to simple suspicions of ML or TF but as situations in which reporting institutions believe that a crime has been/is about to be committed; therefore as being characterized by a "periculum in mora", which requires immediate investigation.

324. While located within the SØK the FIU made it clear during the discussion that they do not act under the orders or instructions of the Director of the SØK in the exercise of their functions and that even though they are part of the Public Prosecutor's Office, they enjoy complete independence in their work. The Director of the SØK confirmed the independence of the FIU by describing it as being "integrated but independent". The decision to establish the FIU within the Prosecutor's office was purely a matter of resources and size of the country.

325. According to the Circular Letter of 1993, the functioning of the FIU is overseen by a Money Laundering Steering Group, which comprises of representatives from the Association of Chiefs of Police, the Copenhagen Commissioner, the National Commissioner and the Public Prosecutor for Serious Economic Crime. The Money Laundering Group does not constitute an hindrance to the operational independence of the FIU. The Steering Group meet only twice a year and it deals basically with issues of coordination between the FIU and the Police districts 9 . 
326. In order to determine to what extent all the 3 core FIU-functions (collection- analysis- and dissemination of financial information) are within the Danish FIU responsibility and how effectively are they implemented, it is worth analyzing in detail how these three functions are carried out by the Danish FIU.

327. The FIU explained that once a suspicious transaction report is received, it is registered in the FIU database and checked against other databases, and eventually combined with other information obtained by other authorities (including foreign FIUs). If the case is not shelved/filed (this situation seldom occurs) a decision is then taken (in most of the cases seen by the evaluators in a relatively short time after the report is received) as to whether to disseminate the report to the competent Police for the territory which has jurisdiction over the criminal investigation or to pursue the matter, internally, in the SØK.

328. Usually STRs which either deal with transit cases, or are reported by lawyers, or are related to TF or another serious economic crime would be investigated internally by SØK. Sometimes in these cases - with the exception of TF for which a more articulated process would apply - the same investigators who conducted the analysis of the case from the FIU perspective would also conduct the criminal investigation (therefore at a pure law enforcement stage). This may pose a resource issue, in a situation of potential understaffing of the FIU since the investigator working on the case at the law enforcement stage would also be assigned to other tasks which do not belong to the FIU mission.

329. The mission was informed that reports from bureaux de change or from money transfer offices concerning transactions below 50.000 DK (appr. 8.000 USD) are not per se considered/classified as STRs and therefore not processed unless there is information from the FIU database or connection with other pieces of information which would confirm the suspicions. In this respect the mission was informed that this information is analyzed on an ongoing basis, with the view of processing it at a later stage if any relevant pattern comes up. This sort of automatic "stand by" of these transactions, which were nevertheless reported as being suspicious, raises some concerns. The circumstance that there is no information relevant to the transaction already in the FIU database or in other sources does not appear to the examiners to be a sufficient reason to conclude, contrary to the STR, that it is not suspicious and should be excluded per se from further FIU analysis. It also poses the risk that cases of ML or TF where relatively low amounts of money are involved will not be discovered.

330. The mission notes that the FIU analysis of the STRs (which, in the cases seen by the evaluators was relatively brief, with the STR disseminated for criminal investigation almost immediately after its receipt by the FIU) could benefit from a broader financial review. Also the FIU could be more effective in determining during the analysis stage which are the cases that are worth "disseminating" to the criminal investigation stage (where it would appear that most of the non database related analysis is conducted).

331. In 2004 and 2005, all STRs received by the FIU were either sent for criminal investigation by police districts or retained internally for investigation by the SØK:

$\begin{array}{lrc}\text { STRs } & 2004 & 2005 \\ \text { Total } & 366 & 450 \\ \text { Investigation police district } & 317 & 350 \\ \text { Investigation SØK } & 49 & 100\end{array}$

332. The analysis of the STRs is limited to basic checks against databases and requests to other authorities for information. Given the law enforcement character of the Danish FIU some blurring of the analysis and investigation stages is inevitable and acceptable in principle. However in Denmark the criminal investigation (especially when STRS are disseminated to local Police districts) substitutes for the FIU's analysis to too great an extent. The FIU should carry out a more in depth analysis of the reports, aimed at adding value to the STRs received, with the view of improving the quality of the information it disseminates. As statistics show, virtually 
all STRs received are disseminated for investigation. The Danish view is that all STRs should be investigated by the Police. However the mission feels that an enhanced analysis of the STRS aimed at selecting those worth investigating and at improving the quality of information that is disseminated to law enforcement makes AML/CFT systems more effective. In particular this approach has the advantages of making a more effective use of law enforcement resources and providing a more robust buffer between the reporting and investigation stages.

333. The processing of the STRs related to FT is different than the one described for STRs related to ML.

334. Whenever such a report is received by the FIU it is preliminarily screened by the FIU with the view to determine cases of false hits. The full analysis of the STR is then done in the framework of a Steering Committee on Terrorist Financing, an informal body comprising the FIU, SØK and the Danish Security Intelligence Service. The reason for this, as it was explained during the meetings, is because of the sensitive nature of such matters and, above all, to bring into the decision-making process, additional intelligence from the Danish Security Intelligence Service. The decision as to whether the STR should go to the criminal stage is taken by the Director of SØK. Given the placement of the FIU within the SØK as a law enforcement FIU, the blurring between the "dissemination" stage and the decision to launch the criminal investigation does not appear to be a hindrance to the operational independence of the FIU.

335. There is no provision in the Act that provides any legal basis or power for the FIU to issue guidance to financial institutions or other reporting authorities, either on the form, manner or substance of the reporting obligations. FATF typologies reports and sanitized cases from the Egmont Group have been provided to the Bankers Association and the Law Society by the FIU. The FIU has undertaken an exercise, with several ongoing projects, aimed at identifying typologies of STs for certain groups of predicate offences (such as drug trafficking, financial frauds and scams), studying common patterns of behavior, for further dissemination to relevant reporting entities. The FIU provides guidance on an ad hoc basis on issues relating to money laundering or the financing of terrorism upon requests from the reporting agencies. The guidelines from the Bankers Association and the Bar Association and Law Society have also been formulated in cooperation with the FIU.

336. However it should be noted that there are no written requirements regarding the manner of reporting, nor are there specification of reporting forms or procedures that should be followed when reporting. In particular the FIU has never issued any format or template regarding the type of information that an STR should contain. There is no standard form used or manner for reporting, although the reporting authorities have to demonstrate the basic reason as to why they are of the view that there is a suspicion. The Guidelines issued by the Bankers Association contain a suggested template for reporting STRs and have been designed to assist the reporting obligation. The lack of standardized reporting procedures and, above all, of a STR template, is of major concern, especially in a situation in which the FIU needs a court order to obtain additional information (see infra) and, therefore, would be particularly useful to establish exactly the data and information that an STR should contain.

337. The FIU has direct access to a wide range of data. This comprises criminal record, the Police database on serious crime; vehicle register, the civil registration information, (CPR), the Companies Registry (CVR) and to the land Registry. It also has indirect access (upon request) to tax authorities information. Information which is obtained from tax authorities is extremely comprehensive and detailed and promptly made available by the tax authorities. In obtaining/processing the information for undertaking its responsibilities the FIU is exempted from the restrictions set forth in the Act on Processing on Personal Data

338. The FIU relies on section 7(5) of the MLA Act to access information from covered institutions in order to properly undertake its functions. Section 7(5) refers, however, to the right of the Police to demand any information necessary for "investigation" of the case from the undertakings and persons covered by the Act. The section is exercisable in accordance with sections 806(2) and (3) and 796(2) and (3) of the Administration of Justice Act which define the circumstances in which the police can seek and obtain information from the banks; basically through a court order. Although the power given under the law to the police may be construed as a shortcoming in the FIU powers, the FIU does not consider the availability of information given under the law to the police to be a restriction to its operations in as much as the FIU is part of the police and its officers are police 
officers and prosecutors. They argue that the power given to the police under section 7(5) of the Act is eventually a power provided to the FIU through the police, on the basis of the Circular Letter 1993, which provides that the daily tasks of the Money Laundering Secretariat is managed by the staff comprising of prosecutors and police officers. To the extent that police officers, wherever posted, always retain their police powers, it may be argued that the power of accessing information regarding the analysis of STRs before the FIU reaches a conclusion as to the fate of the STR, is exercisable by the police posted at the FIU.

339. The provision under 7.5. of the MLA is therefore setting the power of the FIU (as a law-enforcement FIU) to request additional information from the reporting entities. The basic principles is that the FIU as the Police must obtain a court order to get such information. The decision to compel information/ documents from covered entities can be directly taken by the FIU/Police in the case of emergency without a court order (see AoJA, section 806.2, a court decision needs to be taken afterwards). In practice the evaluators were told that in a case of a reported STR usually the reporting institution would provide spontaneously information that is regarded by the FIU as missing from the STRs. The Court order would be needed for any additional information. In a situation in which there is no STR template indicating what information should be included in the report, it appears difficult to determine when some information is considered "missing" or "additional". The evaluators were told that a court order is always needed, for example in the case in which the information sought extends significantly beyond the specific matter and the customer relationship or where it involves other banking institutions and their customer relationships.. While the FIU reported that it had never experienced difficulties in getting court orders, this circumstance may be seen as a shortcoming in the FIU powers to promptly obtain additional information which might be needed for the analysis of the STRs.

340. Although there are no provisions in the MLA Act that refer to the possibility of the FIU disseminating financial information to other competent authorities after the analysis of an STR, the STRs are analyzed/disseminated in the circumstances described above: for STRs related to ML either to the Police district or, in the transit cases, when the STRs are reported by lawyers or refer to serious economic crime or TF to the SØK. In the case of TF there is an involvement of the Danish Security Intelligence Service. The FIU also disseminates information to other authorities such as the tax department or the Customs for investigation in case where a suspicious transaction would indicate a violation of either tax or customs regulations.

341. Information held by the FIU is protected in accordance with the requirements for police information. According to Section 27 of the Danish Public Administration Act, anyone exercising a public office or function has an obligation to keep secret confidential information and other information, where secrecy is needed in order to attend to considerable public or private interests. Confidential information of the police and the prosecutors falls within this provision of secrecy. Moreover pursuant to Section 152 (1) of the Criminal Code, any person who is exercising or has exercised a public office or function, and who unlawfully passes on or exploits confidential information (information designated as confidential by law or by other valid decision or when it is otherwise necessary to keep it confidential for material reasons of public or private interest) which he has obtained in connection with his office or function, is liable to a fine or to imprisonment for up to six months. Under aggravating circumstances, the punishment may rise to imprisonment for up to two years.

342. The relevant information is stored in a database and in an hard copy archive. The database is accessible only to staff assigned to the FIU. The main server used by the FIU for its database is kept separate, well-secured and removed from the main office. While the FIU stated that there are provisions forbidding access to the FIU's files for the SØK officers/employees who are not assigned to the FIU, the hard copy archive (which contains the files on the STRs) however, is physically accessible by any officer of the SØK, as it is located in the same room as the SØK's archive.

343. The FIU began in 2004 to publish an annual report which provide information about AML/CFT. The 2004 Annual Report provides information about the mandate and operations of the FIU and the progress achieved during the previous year. It also provides some details about cross-border transactions of a value exceeding 15,000 EUR, a list of the classes of undertakings subject to the reporting obligation, general information about the reporting of suspicious obligation, money laundering and the financing of terrorism 
indicators, general statistics about the number of STRs received and their outcome, its cooperation with national and international agencies and other information relevant to the functions of the FIU in general. The report was distributed to all the regulated entities and persons and made public, in English, on the internet. It was also placed on the Egmont Secure Web.

344. Denmark's FIU has been a member of the Egmont Group since 1997 and for many years a member of its Legal Working Group. It adheres to the Egmont Statement of Purpose and respects its Principles of Exchange of Information. At the moment, the FIU is a member of the Legal Working Group's work on formulating and improving the standards. The Denmark FIU can provide other FIUs, including administrative FIUs, with any information to which it has access without any court orders. There are no special restrictions to the exchange of information provided the exchange of information is necessary to fight crime and that the secrecy and data protection provisions in the receiving country are found to be sufficient. The FIU does not need an MOU in order to exchange information with other FIUs unless the other FIU requires an MOU. In the case of European Union, Council Decision 2000 covers cooperation between all EU FIUs. The FIU has signed MOUs with Israel, Australia, Canada and other MOUs are being negotiated with Panama, Thailand, Venezuela, Russia, South Korea, Mexico, the Dutch Antilles and Singapore.

\section{Recommendation 30}

345. The staff of the ML Secretariat comes from the Office of Public Prosecution for Serious Economic Crime which is itself a branch of the prosecution service governed by the Minister of Justice. The Director for Public Prosecution supervises the work of the public prosecutors. The FIU has a permanent staff of seven police investigators, three prosecutors and one administrative officer. The FIU indicated that, whenever necessary, SØK provides it with supplementary staff for the performance of its functions. It also at times enlists the services of private auditors for purposes of competence and independence in respect of complex financial investigations.

346. The staff of the FIU is recruited from the police force and more precisely from CID Divisions. There is an in-house advertising process and the applicants are interviewed by management. The selection is done on the basis of the interview, experience and personal history, competence, conduct and behavior. There is also an annual assessment carried out to monitor the performance and conduct of the officers. As far as discipline is concerned, the same procedure as is applicable to the police force is applied in cases of breach of the disciplinary regulations. Disciplinary cases are dealt with by a Disciplinary Board and sanctions vary from a fine to dismissal. Apart from these requirements, there are no special procedures regarding the recruitment or vetting of the FIU officers.

347. However, under the Civil Servants Act, the behavior of civil servant, including FIU officers, both outside and inside the service, must be worthy of respect and confidence of their professions. Civil servants are regulated under strict rules of conduct and demand high standards of behavior. They should avoid situation which place them in a situation of conflict and which are likely to raise doubt as to their partiality. There are strict rules of secrecy for everyone employed in the public sector.

348. FIU personnel receive the same training as other prosecutors and police officers assigned to SØK including specialized courses on economic crime. This includes for most officers two and half weeks of training over a three year period in specialized courses on economic crime. In addition, FIU personnel generally take basic and advanced IT courses that address such topics as searching computers and securing for content. The officers have also had some training on the financing of terrorism, data analyzing systems used by FIUs in general, cash assets and money laundering. Regarding training of police and prosecutors assigned to SØK, including FIU personnel, see section 2.6. While Police Academy and other courses taken appear to be excellent, there could be additional emphasis on more specialized training for FIU police officers, on techniques for tracing proceeds of crime, financial analysis techniques and skills, and specialized training on FT.

349. The FIU is satisfied that the staff allocated to the FIU is sufficient in the context of the amount of STRs that it receives and analyses per year (400-450). Considering the likely increase in numbers of STRs, the 
desirability of more extensive analysis of STRs, and the possibility that staff may be asked to conduct investigations for the $\mathrm{S} \varnothing \mathrm{K}$, there is some concern that the current level of staffing will not be sufficient going forward..

\section{Recommendation 32}

350. The information provided during the evaluation indicates that the FIU has in place a system of keeping statistics relating to STRs. The statistics disclose the number of STRs reported, with the figures broken down in terms of the reporting entities as well as the numbers disseminated. They also reveal the outcome of the reported STRs. The statistics are prepared on the basis of geographical affiliation and gives an indication of the geographical distribution of the no. of STRs registered. Statistics are also kept in relation to requests from other countries to the FIU.

351. The number of STRs received under the Money Laundering Act and the Gambling Casino Act are as follows (the figures for 2005 up to 12/12):

\begin{tabular}{|l|c|c|c|c|c|c|}
\hline & $\mathbf{2 0 0 0}$ & $\mathbf{2 0 0 1}$ & $\mathbf{2 0 0 2}$ & $\mathbf{2 0 0 3}$ & $\mathbf{2 0 0 4}$ & $\mathbf{2 0 0 5}$ \\
\hline Banks & 133 & 205 & 216 & 176 & 200 & 194 \\
\hline Mortgage credit institutes & 1 & 0 & 1 & 1 & 2 & 2 \\
\hline Insurers and investment managers** & 0 & 0 & 0 & 0 & 0 & 1 \\
\hline Foreign exchange bureaus & 114 & 114 & 115 & 77 & 109 & 121 \\
\hline Money remittance operators ** & & & & 17 & 42 & 95 \\
\hline Lawyers** & & & & 6 & 9 & 6 \\
\hline Auditors and tax advisors** & & & & 0 & 0 & 1 \\
\hline Real estate agents** & & & & 0 & 1 & 0 \\
\hline Postal services** & & & & 1 & 0 & 0 \\
\hline Money transport services** & & & & 0 & 0 & 0 \\
\hline Other*** & & & 6 & 0 & 1 & 0 \\
\hline Casinos & 3 & 0 & 0 & 2 & 2 & 0 \\
\hline Total & $\mathbf{2 5 1}$ & $\mathbf{3 1 9}$ & $\mathbf{3 3 8}$ & $\mathbf{2 8 0}$ & $\mathbf{3 6 6}$ & $\mathbf{4 2 0}$ \\
\hline
\end{tabular}

* Up till 12/12 2005 (the total number of STRs for 2005 is of 450, out of which 32 related on TF)

** From June 2002

*** From June 2002 (an overall figure in 2002 for new businesses subject to the duty of reporting).

352. The number of STRs received by region (the figures for 2005 up to 7/10) are as follows:

\begin{tabular}{|l|c|c|c|c|c|c|}
\hline Region & $\mathbf{2 0 0 0}$ & $\mathbf{2 0 0 1}$ & $\mathbf{2 0 0 2}$ & $\mathbf{2 0 0 3}$ & $\mathbf{2 0 0 4}$ & $\mathbf{2 0 0 5}$ \\
\hline Western Europe & 29 & 56 & 97 & 89 & 103 & 168 \\
\hline Eastern Europe & 20 & 17 & 17 & 16 & 25 & 24 \\
\hline North America & 3 & 8 & 17 & 14 & 8 & 13 \\
\hline Central and South America & 0 & 3 & 0 & 11 & 8 & 24 \\
\hline Africa & 6 & 56 & 37 & 37 & 23 & 52 \\
\hline Middle East and Asia & 23 & 119 & 111 & 104 & 33 & 88 \\
\hline Australia and New Zealand & 1 & 1 & 1 & 2 & 2 & 1 \\
\hline
\end{tabular}


* Up to $7 / 10 / 2005$

353. Although they maintain and evaluate statistics on incoming STRs and their disposition,, the Danish authorities admit that it is difficult to measure the effectiveness of the system on the basis of the existing system of statistics. They consider that because many cases are minor in nature and since self-laundering is not reflected, the statistics do not capture all that is necessary to evaluate the effectiveness of the system. However, they agree that it would be important for the authorities to be able to evaluate the evolution of Danish cases in order to understand what proceeds have been generated and to analyze what occurs with the proceeds. It is thought that this would assist the authorities compare information with STRs and convictions to evaluate among other things if there are STRs that should have been sent or cases where prosecution should have been considered.

\section{Recommendations and comments}

354. The analysis of STRs should be enhanced beyond simple data matching and the role of the FIU in analyzing the STRs and in substantiating suspicions should be strengthened, also with the to improve the quality of the information that is disseminated for investigation.

355. There should be written requirements regarding the manner of reporting, as well as reporting forms or procedures that should be followed when reporting.

356. Considering the likely increase in numbers of STRs, the desirability of more extensive analysis of STRs, and the possibility that staff may be asked to conduct investigations for the SØK, the staff of the FIU should be increased.

357. More specialized training should be made available to the FIU staff.

\begin{tabular}{|c|c|c|}
\hline \multicolumn{3}{|c|}{ Compliance with FATF Recommendations } \\
\hline & Rating & Summary of factors relevant to section 2.5 underlying overall rating \\
\hline $\mathbf{R . 2 6}$ & $\mathrm{LC}$ & $\begin{array}{l}\text { - The analysis of the STRs is insufficient. } \\
\text { - There are no requirements regarding the manner of reporting, nor are there } \\
\text { specification of reporting forms or procedures that should be followed } \\
\text { when reporting. In particular the FIU has never issued any format or } \\
\text { template regarding the type of information that an STR should contain. } \\
\text { - The FIU can obtain additional data only through a court order. This } \\
\text { circumstance is a shortcoming in the FIU powers to promptly obtain } \\
\text { additional information which might be needed for the analysis of the } \\
\text { STRs. } \\
\text { While access to the FIU database is limited to staff assigned to the FIU } \\
\text { and there are rules prohibiting other SØK staff access to the hard copy } \\
\text { archive; the hard copy archives of the FIU is on a practical level } \\
\text { physically accessible to SØK as well. }\end{array}$ \\
\hline \multicolumn{3}{|c|}{$\begin{array}{l}\text { 2.6 Law enforcement, prosecution and other competent authorities-the framework for } \\
\text { the investigation and prosecution of offences, and for confiscation and freezing (R.27, 28, } \\
30 \text { \& 32) }\end{array}$} \\
\hline \multicolumn{3}{|c|}{ Description and analysis } \\
\hline
\end{tabular}


358. The Police in Denmark, Greenland, and the Faroe Islands are part of the MOJ. The Minister of Justice exercises his police powers through the National Commissioner of Police, the Commissioner of the Copenhagen Police and the Chiefs of Police that oversee 54 Police districts. Statutory provisions governing the work of the police appear in the AJA.

359. The National Commissioner of Police (NCP) provides a centralized supporting function in the administration of the police. The NCP is responsible for all personnel and finance matters and has several specialized supporting offices including the Office of the Danish Security Intelligence Service, the Serious and Organized Crime Agency and the Police College. Operational police work occurs in police districts. The Office of the NPC has approximately 2449 staff members (including 1522 students at the Police College).

360. The Danish Security Intelligence Service is responsible for preventing and investigating actions that may jeopardize the independence, security and legal order of Denmark. It works to prevent such actions from being implemented or developed. The Danish Security Intelligence Service handles intelligence concerning and investigations relating to terrorism including, in cooperation with the Money Laundering Secretariat (Denmark's FIU), the financing of terrorism.

361. The Serious and Organized Crime Agency serves as a national criminal investigation support centre to assist police districts in combating serious organized crime at both national and international levels. It has a staff of approximately 200. Its four units (the National Crime Intelligence Service (NCIS), the National Crime Squad (the Flying Squad), the Communication Centre, and the Counter Terrorism Unit) monitor and analyze national and international data and intelligence that relates to organized and border crossing crime. There is special emphasis on biker crime, organized street gangs, drug trafficking activity, contraband smuggling, trafficking in women, money counterfeiting, credit card fraud, arms theft, and Eastern European crime groups. The Agency cooperates closely with the FIU and the Public Prosecutor's Economic Crime Intelligence Unit.

362. The Police College is engaged in developing and implementing training programs for new police recruits and providing ongoing training for police professionals.

\section{$\underline{\text { Police Districts }}$}

363. Denmark has a decentralized system for its police force. Police activities and prosecutions are supervised in each of 54 police districts (plus the Faroe Islands and Greenland) by the district's Chief of Police. The 54 police districts taken together have 7702 officers assigned. Copenhagen where over a third of Denmark's population of 5.4 million resides has approximately 1770 officers. Depending upon a district's size, there may be one or more deputies as well as assistant prosecutors with legal training. Each police district has both a uniformed branch and a criminal investigation department (CID). Although in the larger districts, there may be units within the CID that focus on particular kinds of criminal activity (economic crime, violent crime, etc.), as a rule there is not a level of specialization such that particular officers deal solely or primarily on ML although one officer may screen the STRs forwarded by the FIU for investigation. The Chief of Police serves as the public prosecutor in the district court and is responsible for the work of police prosecutors who serve as part of his/her office. When an investigation concludes with a decision to prosecute, the Chief of Police or his/her deputies or assistants appear before the district court as the prosecutor in the case. In 2005, all police districts had ML investigations. District police officials are experienced in ML investigations and if they encounter difficulties, they contact the FIU or SØK. They also cooperate with each other, as needed.

364. The structure of the Danish police is under review and Parliament is expected to consider a significant reduction in the number of police districts to 10-12 with an aim, among other things, of increasing capabilities in more complex cases including cases concerning economic crime. 
365. Denmark's Central Customs and Tax Administration is the agency that oversees customs and tax matters. The Administration is not invested with law enforcement powers but coordinates closely with the police on such matters. Approximately 600 customs officers serve in a number of regional customs offices and report to a headquarters office. Customs authorities receive declarations concerning transportation into or out of Denmark of cash or similar values that exceed 15,000 EUR. Customs authorities may hold undeclared cash or equivalent values and inform the police who then take appropriate action including arrests and/or seizure of assets. Customs and tax authorities may participate in special case related task forces if a case involves a major violation of customs or tax legislation. In addition such authorities are required based upon circular letters to file STRs if there is a suspicion of ML.

Police staffing and training

366. In 2005, the Danish Police service employed approximately 9224 police officers, 1190 police trainees, and 2643 clerical and civilian administrative and other staff (2643). Denmark has a highly professional police force. Police officials are required to maintain high professional standards, including standards concerning confidentiality, and the force has a history of integrity. Denmark's Civil Servants Act requires that civil servants conduct themselves in a professional manner. The Danish Public Administration Act at Section 27 imposes an obligation on persons exercising a public office or function to maintain as secret confidential information and other information, where secrecy is needed for considerable public or private interests. Violations are punishable under Section 152 (1) of the Criminal Code.

367. The police authorities both in the NPC and in the 54 police districts are career services with a tradition of independence. Police recruits begin with a three year basic training program, which includes a year in the field and two years of Police Academy training that covers Danish Criminal Code and AJA matters, among others. There is general awareness training about the money receiving and financing of terrorism offences. Police recruits are trained to look for crime rather than particulars regarding how to handle the financial aspects of crime.

368. As part of its regular training program, officers must also attend week long training courses after 6-8, 14-16 and 22-24 years of service with such programs focused to assist the specific officer with the assignments within his/her career path. Some regional based police officers also rotate in for temporary assignments (often 2 to 4 years in length) with $\mathrm{S} \varnothing \mathrm{K}$ and the assignment serves as on the job training. These temporary assignments supplement SØK’s permanent staff.

369. For officers assigned to CIDs within the Districts (all Districts have such Departments) and to SØK (if the assignment is for a period in excess of two years), three advanced investigations courses are available, with some required. The three level program has a two week basic course, a second two week course and a third advanced level one week course. Each SØK officer takes the basic course and generally the second course as well. In addition, some officers take the third single week (most advanced) course. The courses address economic crime, have a model case based approach, and cover such matters investigative stages and team composition, coercive measures, special investigation techniques and international investigative methods. The courses are offered about four times a year and approximately 100 officers are trained at each level in the course of a year. Additionally each SØK officer and some regional staff as well as prosecutors attend two specialized courses that are offered through contractors, each a week in length, that relate to technical skills such as understanding balance sheets and dealing with company organization.

370. The Public Prosecutor also arranges regional one day seminars on matters such as mutual legal assistance and extradition which police officers attend.

The Public Prosecution Service 
371. Denmark's Prosecution Service is under the supervision of the Minister of Justice. The Service has a Director of Public Prosecutions, six regional public prosecutors, two public prosecutors with nationwide responsibility (the Public Prosecutor for Serious Economic Crime and the Public Prosecutor for Special International Crime) and 54 Chiefs of Police and a total of about 560 public prosecutors. Approximately 25 serve in Office of the Director of Public Prosecutors, approximately 130 are within the regional public prosecutors and the two prosecutors with a nationwide responsibility. The rest serve as prosecutors in the police districts with the number assigned dependant upon the size of the district. The Director of Public Prosecutions is responsible for overseeing all prosecutions in Denmark and handles criminal cases before the Supreme Court. The Director also oversees special national jurisdiction prosecutorial offices, including SØK. District based police prosecutors handle criminal cases in 82 County Courts under the supervision of the district's Chief of Police. Regional public prosecutors take responsibility for appellate and jury cases before Denmark's two High Courts and supervise handling of criminal cases by the Chiefs of Police before the County Courts. A decision of a public prosecutor can be appealed to the Director of Public Prosecutions and those of the Director of Public Prosecutions may be appealed to the Minister of Justice. All prosecutors in Denmark are part of the MOJ.

\section{The Office of the Public Prosecutor for Serious Economic Crime (SØK)}

372. The Office of the Public Prosecutor for Serious Economic Crime (SØK) was established in 1993 as a special branch under the Director of Public Prosecutions. It has national competence to address the most complex and serious cases of economic crime within Denmark. SØK addresses inter alia matters that involve corruption, fraud (including investment fraud), embezzlement, breach of trust, tax offences, extortion, usury and insider trading. Some of the factors it considers in deciding whether to take responsibility for a case are the complexity of the case, whether there is a link to organized crime, whether special business methods were involved or whether the case is serious is some other way.

373. The office is headed by the Public Prosecutor for Serious Economic Crime. At the time of the mission the office had 24 prosecutors, approximately 56 investigators and approximately 10 supporting staff. Auditors are employed on a case-by-case basis to assist the prosecutors and investigators. The Money Laundering Secretariat (Denmark's FIU) is integrated into SØK and is assigned three prosecutors, seven police investigators and an administrative officer.

374. The office has two investigative/prosecutorial Sections, a legal secretariat that includes the FIU, an investigation support section that provides police support to police-district based economic crime investigations (the Economic Crime Investigation Service), and administrative, IT support and innovation/operation sections. 


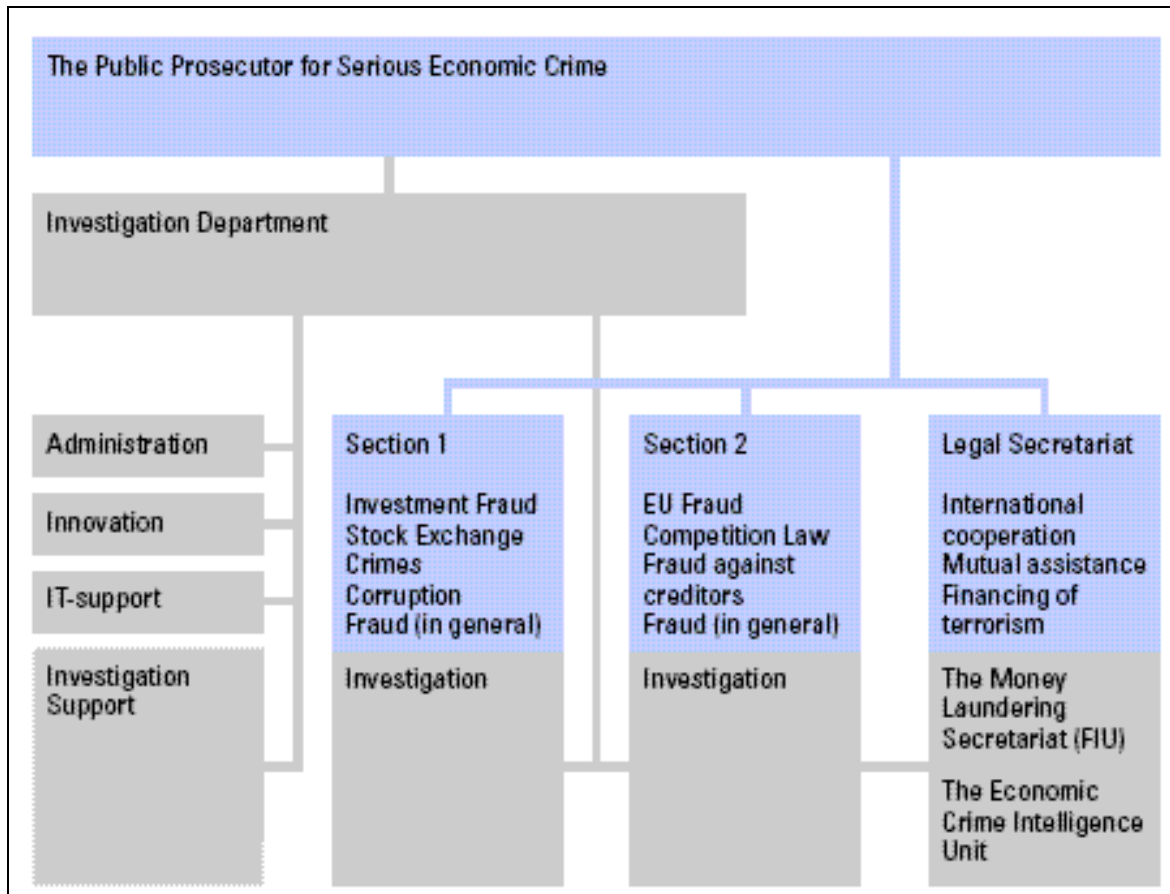

375. The budget for the MOJ including its police and prosecutorial function is determined by the Parliament on an annual basis after a submission by the government of its needs based upon MOJ input. SØK is assigned resources by the Minister of Justice. For SØK prosecutorial staff, SØK's Director works out needs on an ongoing and flexible basis with the Public Prosecutor. For SØK police staff, the Director does the same with the NPC. In this way, SØK has access to significant and flexible resources based upon its specific needs at any point in the year. SØK appears to have received the resources necessary to handle all cases and matters assigned. Regarding the overall MOJ budget, the Parliament has given a high priority to terrorism and organized crime and authorities report that the budget has received increases in recent years.

\section{$\underline{\text { Steering Groups and Support Mechanisms }}$}

376. A mechanism for support to police districts in the case of serious crime is available through the NPC's Serious and Organized Crime Agency, and mechanisms for coordination in specified criminal subject matter areas exist through a series of steering groups of high level police and prosecutorial officials.

377. A Steering Group on Organized Crime coordinates efforts to combat organized crime. The National Commissioner, the Director of Public Prosecutions and other representatives of the police and public prosecution office serve on the steering group. The Customs and Tax Administration participates on an ad hoc basis.

378. A Steering Group on Financing of Terrorism is the mechanism for cooperation between the Danish Security Intelligence Service and SØK. The Group considers cases under investigation as well as general questions, and serves as the national contact point for cooperation with Europol on countering the financing of terrorism. The Steering Group appoints a project group with representatives from the FIU and the Danish Security Intelligence Service for specific investigations. The investigation, which has a FIU prosecutor assigned, is conducted based on Steering Group guidelines with reporting to the Steering Group. Among the general issues considered by the Steering Group are outreach to various population groups regarding money remittance and charitable donations.

379. A Money Laundering Steering Committee has been operational since 1993 when the FIU was 
established. It meets twice a year for about a half day and has representatives from the NPC (including the National Crime Intelligence Service), the Chiefs of Police Association, the Commissioner of the Copenhagen Police and SØK (including the FIU). The Committee is a forum for discussion of current topics of interest, an opportunity for SØK to receive feedback from the police districts, and to evaluate whether there need be changes in the handling of STRs. Consideration is given to topics such as methods for handling new kinds of STRs as those filed by lawyers. Police districts are advised of Steering Committee decisions. Committee members hear reports regarding FATF meetings and developments in the international AML/CFT arena.

\section{$\underline{\text { Prosecutorial staff and training }}$}

380. Prosecutors serve within the MOJ and are required to maintain high professional standards both as civil servants and as lawyers and must maintain standards concerning confidentiality. As noted with respect to the police, Denmark's Civil Servants Act requires that civil servants conduct themselves in a professional manner and the Danish Public Administration Act at Section 27 imposes an obligation on persons exercising a public office or function to maintain as secret confidential information and other information where secrecy is needed in order to attend to considerable public or private interests. Violations are punishable under Section 152 (1) of the Criminal Code. Section 126(1) of the AJA also requires that lawyers act in accordance with the code of conduct for lawyers. Given these standards and the highly professional nature of the prosecutorial staff, confidentiality appears to be appropriately maintained.

381. Training of prosecutors generally occurs through on-the-job work under the supervision of more senior prosecutors. Prosecutors begin their training handling matters in the county courts and, after a period of time, are promoted to other levels. Training of prosecutors is also dealt with in the framework of Denmark's programs in the fight against economic crime. Each SØK prosecutor has an individualized program of training, with seminars and courses dependant upon the needs for individual development as well as office and special case needs. Prosecutors will often attend the two specialized training courses noted above for police regarding financial statements and corporate structures. The training courses for police and prosecutors have been developed through a close co-operative relationship between SØK and the Police College. In addition, SØK provides day long in-house seminars for its staff, both prosecutors and police, from time to time on topics of special interest as mutual legal assistance. No special training of judges is provided.

382. Though both prosecutors and law enforcement personnel who are involved in economic crime issues have opportunities for (and in some cases are required to take) training courses, they relate to broad issues relating to economic crime and have only a limited focus specifically on ML or FT. More particularized training that covers ML and FT typologies, and ML and FT issues as they may arise in the Danish context, as well as more intensive training on techniques for tracing property and ensuring it is seized, frozen and confiscated would be helpful.

\section{Criminal investigation and prosecution of money laundering}

383. ML cases in Denmark are money receiving cases under Section 290 of the Criminal Code and most such cases are simple receiving stolen goods matters. The investigation and prosecution of such cases is handled both at the police district level and by SØK depending upon the level of complexity of the crime. If the matter involves significant economic criminal activity, it would in the ordinary course be handled by SØK. All other matters are handled by police district investigators and prosecutors. In either instance, there is a clear designation of responsibility for such cases, whether they emanate from STR filings or are developed in another manner.

384. Denmark places responsibility for investigating ML offences primarily in its 54 local police districts. Each Chief of Police, and for Copenhagen, the Commissioner of the Copenhagen Police is independently responsible for the management and execution of duties within his or her district and reports to the Minister of Justice. Denmark's FIU passes on information from STRs to the police district that will conduct the investigation and the districts report the outcome of their investigations. The police districts also address local criminal cases including ML cases, and may be part of a team that conducts FT investigations. Police districts are involved in 
the tracing of proceeds and seizure of assets as these are integrated parts of criminal investigations.

385. There is no special unit that is assigned investigation responsibility for ML cases. In simple cases, the investigation is carried out by the police district using its usual procedures. It is overseen by the Chief of Police who also serves as the prosecution authority within the district. As noted above, in a more serious or complicated case, the investigation may be undertaken by SØK. The FIU, which is part of SØK, generally refers more serious matters and matters where the relevant conduct occurred largely in other jurisdictions to SØK for investigation. Police districts consult SØK on significant cases as they develop.

386. There are special arrangements for investigations that emanate from specific kinds of STRs. Under policies currently in effect, for STRs in matters where there is no link to Danish residents or legal entities, or where the matter arises from an STR filed by a lawyer, the investigation emanating from the referred STR is undertaken by SØK and specifically by the staff assigned to the FIU. All SØK police investigative staff and prosecutors have powers to investigate, trace, search and seize. The FIU is generally informed about all ML cases other than minor ones and, together with the Economic Crime Intelligence Unit, will gather and provide relevant information for investigators and prosecutors. In addition SØK has been designated by the Minister of Justice to investigate and prosecute violations of obligations relating to preventive measures under the MLA.

387. The AJA is the basic act that sets forth rules of investigation and prosecution for criminal acts. If a matter involves a criminal act liable to public prosecution, the police initiate an investigation on the basis of information they gather or that is provided to them, and prosecute the matter. The police work closely with prosecutors and under their general supervision. In the investigative stage of a case, prosecutors do not normally become involved unless a particular legal issue arises.

388. In Denmark once an investigation has been completed, a prosecution must occur unless there is a good reason not to go forward. Persons with a legal interest, for instance, a victim or the person who filed a report, may have a decision by the prosecutor not to prosecute reviewed. Prosecutors virtually always take action when it is warranted by the evidence. Prosecutors supervise investigations undertaken by the police, decide on and file motions for coercive measures, institute charges and prosecute cases before the courts. ML cases (including activities that constitute self laundering) are considered for prosecution by SØK in the case of matters that that office has investigated and by the local police prosecutor associated with the Chief of Police for the District in cases investigated locally. The prosecutions themselves are also thereafter handled by a SØK if that office has responsibility for a case or by a local prosecutors (in the cases for which they are responsible) which brings the case before the district. No specialization exists for ML cases and none of these prosecutors do in practice specialize only in ML or TF cases. FT cases are/will be prosecuted by prosecutors within SØK.

389. Law enforcement authorities and prosecutors have discretion to proceed with coercive measures, seizures of proceeds and arrests of suspects whenever it is in the best interests of the investigation as long as innocent individuals will not thereby be harmed. Accordingly they may postpone these actions in order to gather additional evidence or identify other participants.

390. Between 2000 and 2005, a total of 9407 judicial investigations under Section 290 (and its predecessor sections) were undertaken. Of the total number of investigations, 2599 were closed without charges being instituted, and 6771 led to cases being submitted to the Court or charges instituted. During the same period, 6443 cases led to conviction and 37 were disposed of with other decisions.

$\underline{\text { Criminal investigation and prosecution of FT }}$

391. The FIU and the Danish Security Intelligence Service (which is part of the Police Service in Denmark) jointly investigate and prosecute cases relating to the financing of terrorism. On an occasional basis, a police district may also undertake such a case in consultation with SØK based upon its development of the case. 
392. Denmark has clearly designated law enforcement authorities to ensure proper investigation of ML and FT offences and both SØK and local police appear to thoroughly investigate matters that arise through STRs and from other means. The structure of using both SØK and local police districts to handle ML matters keeps a level of general expertise within the larger police organization, and ensures specialized expertise is available. Police authorities have full powers to conduct such investigations and there are adequate legislative tools to permit access to evidence. Prosecutorial and investigative resources appear adequate for the current investigative and prosecutorial caseloads and there is a high degree of flexibility built into the system with general as well as specialized resources available for both investigations and prosecutions.

\section{$\underline{\text { Additional Elements }}$}

393. There are a wide array of special investigative techniques available under Danish law. Provisions in the AJA provide a legal basis for the use of such techniques in various investigations of serious crime including ML and FT investigations. In general, the techniques are used to target serious criminal offences that serve as predicate offences to ML such as drug trafficking.

394. The Serious and Organized Crime Agency of the NPC has a special unit that handles matters relating to use of agents and informants and ensures compliance with the legal provisions for their use. The Agency also coordinates controlled deliveries.

395. Among the special investigative means provided for directly in Danish legislation are special forms of search and seizure, interception of communications including mails, telephone tapping, data capture, logging, observation and the use of agents. Other techniques, for instance controlled delivery are permitted if they are conducted in accordance with Chapter 67 of the AJA (General Rules of Investigation). These are set forth in government orders and circulars. In general, for a technique to be available, the offence must be punishable with imprisonment for six years or more. This is met in the case of aggravated ML and for TF offences. In a few instances, there is wider or narrower availability.

396. The Danish legal system's rules for use of special techniques seek to balance criminal investigative needs with the protection of individual rights. Under AJA sections $754 a-b$, for police to arrange for assistance to be offered to an individual in connection with the commission of a crime there must be: 1) a strong suspicion that the offence is about to be committed or attempted; 2) other investigative steps would not be suitable to gather the evidence in the case, and 3) the investigation must concern an offence punishable under the Danish Criminal Code by imprisonment of six years or more. Similar conditions exist with respect to invasions of the secrecy of communication. They may occur only if: 1) there are specific reasons to presume that messages are given or mail is delivered by the means in question to or from a suspect; 2) the invasion is presumed to be of crucial importance for the investigation, and 3) the investigation concerns an offence which under the law can be punished with inter alia imprisonment six years or more.

397. The police may obtain a court order to capture data in an information system that is not available to the public by means of software or other equipment (section 791b, AJA) as well as carry out several individual searches without immediate notification (section 799) and order a third party to surrender documents, etc. (discovery) without a prior court order in urgent cases (section 806). Police may conclude an agreement with a civil person to act as an agent of the police in relation to a specific investigation (section 754b-2). The law also provides that telecommunication companies and Internet service providers must record and store ("log") information concerning transmitted telecommunications and internet information for a period of a year (section 786). Controlled deliveries and the use of informants are permissible if their use is in compliance with the AJA's general rules of investigation. Undercover agents may also be used if authorized by a court. (Section 754a of the AJA). Where a specific measure requires a priori authorization by the court, a specially appointed defense lawyer reviews the case and may interpose comments on the use of the measure prior to the court decision.

398. In addition, Denmark is party to a range of international conventions and agreements on mutual legal 
assistance and counter terrorism that address the use of special investigation techniques. To the extent that the AJA does not specifically address such techniques, they may nonetheless be used as needed. They are regulated through government orders or departmental circulars in accordance with Chapter 67 of the AJA (General Rules of Investigation).

399. Investigative methods are also generally applicable in the case of investigations of crimes related to the planning or carrying out of acts of terrorism.

400. There are no permanent or temporary groups of financial investigators that specialize in investigating the proceeds of crime. Personnel in SØK or CIDs within police districts will provide assistance as needed to other divisions in this regard.

401. Denmark engages in co-operative investigations with other countries as needed or requested and will use special investigative techniques that are available in both jurisdictions if there is a clear indication of need.

402. ML and FT methods, techniques and trends occurring within Denmark are not regularly evaluated on an inter-agency basis but the FIU makes available through the Steering Committee on Money Laundering and through informal means FATF typologies report and relevant international regulations that address current trends.

Investigative Powers

403. As the discussion in paragraphs 404-410 below sets forth, police have the necessary powers to carry out investigative tasks. They may seek court orders for searches and seizures and seek the production of documents and other evidence. Police are also invested with authority to act on their own in exigent circumstances and seek authorization within a short time period after undertaking a measure.

\section{$\underline{\text { Search, seizure and production orders }}$}

404. Danish law provides adequate powers to compel documents including transaction records, to search, to seize relevant documents and evidence and to secure witness statements for investigations and prosecutions of ML, FT and predicate offences. Sections 793-800 of the AJA permit authorities to conduct searches of documents, papers, other objects, residences, dwellings, and other premises both in the case of suspects and nonsuspects, and regulates when a court order is necessary. They provide adequate powers to the authorities and permit searches by the police without a prior court order in some circumstances.

405. Sections $801-803$ of the AJA permit seizures and set forth the principles, permissible purposes and applicable procedures. Under Section 801, a seizure may take place for any of four purposes. They are to secure: evidence, the claim of the State for costs, confiscation and fines, or the claim of the victim for restoration or compensation; or when a defendant has absconded from further prosecution of the case. Generally a court order is necessary but a individual may also give consent. Under Section 806(3) of the AJA, the police may also proceed with a seizure under Section 802 (of objects at the disposal of a suspect) if awaiting the order will jeopardize the matter, and thereafter at the request of the person against whom the measure was directed may have the case presented within 24 hours to the court. Notice is not required prior to a search and seizure nor would it as a rule be provided.Under Section 802, seizure of objects from a suspect may occur if the person is reasonably suspected of an offence and there is reason to presume that the object may serve as evidence, should be confiscated or forfeited, or that, through the offence, it was unlawfully taken from another who would have a claim for it. There may be a seizure of goods a suspect owns if the person is reasonably suspected of an offence and the seizure is considered necessary to secure a claim for confiscation, fines or third party damages.

406. Danish law adequately provides for the production of documents and other objects. See, discussion of production and tracing orders in section 2.3 on confiscation above.

407. The AJA also provides protection to the investigatory and prosecutorial processes through Section 
748 of the AJA which provides that suspects need not be informed of hearings on orders for various measures as discovery and search and seizure measures. The section also provides in appropriate instances for the exclusion of the suspect from the court hearing, for the barring of a suspect from becoming acquainted with entries in the court records, and for orders to counsel not to inform a suspect of matters occurring at a hearing.

408. Under Sections 189, 803(1) and 804(2) of the AJA, non-suspects who have been the subject of productions or seizures, and persons questioned as witnesses may be bound to secrecy by the court or the police if, inter alia, it is necessary in addressing a serious offence.

\section{$\underline{\text { Witness statements }}$}

409. Under Section 750 of the AJA, the police may interview persons but they cannot order the provision of a statement. If a person declines to provide a statement, the prosecutor is free call the person for questioning in court. See, Sections 174 and 178 of the AJA. In this setting, a witness must respond unless there is a special exemption from duty to provide a statement.

\section{$\underline{\text { Statistics }}$}

410. Regarding statistics maintained and their adequacy, see discussions on statistics in sections 2.1, 2.2, 2.3 and 2.4 above.

\section{$\underline{\text { Review by Country of Effectiveness of system for combating ML and FT }}$}

411. Denmark has not undertaken the kind of in depth review on a regular basis of the effectiveness of its AML systems as envisioned by FATF Recommendation 32. As it relates to law enforcement, Danish authorities have not conducted significant analysis and review regarding whether the law enforcement and prosecution pieces come together to produce an effective AML/CFT program in the criminal sphere. In the case of ML, this is underscored by the fact that there is only anecdotal information on the nature of ML cases that authorities proceed with, and the lack of meaningful statistics regarding the proceeds that are seized and confiscated or fines imposed for ML and for predicate crimes. Statistics on investigations, prosecutions, convictions etc. that differentiate the simple ML cases from aggravated or more complex cases and statistics that track success in identifying proceeds and executing against them form one base for conducting this analysis.

412. In addition, although the Money Laundering Steering Committee addresses practical issues of implementation and dissemination of information from Denmark's participation in international fora with respect to AML/CFT, it does not appear to serve a role in analyzing the effectiveness of Denmark's overall efforts.

413. With respect to FT, there are such limited matters that until now the authorities have not seen a need to have a formal statistics gathering and evaluation system in place, with the Steering Committee handling this on an informal basis. Denmark's overall review of the effectiveness of AML/CFT initiatives should include a review of the statistics of FT.

414. The Steering Group on Terrorist Financing should also have a clearer mandate as the central point for receipt and execution of all international (mutual legal assistance) requests. Since many international requests are sent for direct execution to judicial and police authorities and other requests are sent to the MOJ or MFA, there appears to be no specific mechanism for all matters to be centralized in one place (other than informal understanding that may not extend to all police districts) so that all appropriate links can be made and statistics maintained. This is addressed in Section 6.3 of the report and a recommendation made there.

415. There is a layer of complexity for Denmark in trying to determine whether it is effective in its use of criminal provisions to address ML conduct. The Danish ML offence brings within its ambit much conduct that although technically ML is small scale receiving of stolen property. It is important that in statistics gathering and evaluation, these cases be differentiated and that there be analysis of how the Danish ML offense is actually being used for both simple and aggravated cases that represent more than small scale receiving. At the same time 
since self laundering may be pursued as a criminal offence only in the unusual situation where the predicate offence is for some reason not pursued, for Danish authorities to have a full view of effectiveness of its systems necessitates finding a way to capture statistics and information on the ML conduct pursued in predicate offence prosecutions. Danish AML systems and efforts may well be contributing to uncovering self laundering conduct and having it ultimately addressed by criminal actions and confiscatory measures. It is however a hidden factor and information and statistics gathering is not currently set up so that effectiveness can be measured.

416. Law enforcement resources and structures were not reviewed as they relate to Greenland and the Faroe Islands.

\section{Recommendations and comments}

417. Danish authorities should use the Money Laundering Steering Committee or another like mechanism to regularly evaluate the effectiveness of its AML/CFT program. As it relates to the law enforcement aspects of AML/CFT, the committee would consider such matters as investigations and cases instituted, the nature of such cases and the success in tracing, seizing, and recovering proceeds (or alternatively the success in imposing and collecting fines that are equivalent to the proceeds amounts).

418. Denmark should improve its statistics gathering and analysis of such statistics.

419. More particularized training that covers ML and FT typologies, and ML and FT issues as they may arise in the Danish context, as well as more intensive training on techniques for tracing property and ensuring it is seized, frozen and confiscated would be helpful.

\section{Compliance with FATF Recommendations}

\begin{tabular}{|l|l|l|}
\hline \multicolumn{1}{|c|}{ Rating } & Summary of factors relevant to section 2.6 underlying overall rating \\
\hline R.27 & C & \\
\hline R.28 & C & \\
\hline
\end{tabular}

\subsection{Cross Border Declaration or Disclosure (SR.IX \& R.32)}

\section{Description and analysis}

\section{Special recommendation $I X$}

420. Denmark has had a declaration system to monitor incoming and outgoing cross-border transportation of cash in place since June 2002 as part of the laws enacted concerning the combating of FT. Under Section 23(4) of the Customs Act any person physically entering or leaving or sending or receiving covered items in or out of the Danish tariff area, must declare, on their own initiative, all "money etc" exceeding the value of 15.000 EUR/US. They must stop at customs for control and declare such amount of money to the customs-tax authorities. Under Section 79 of the Customs Act, any person who breaches that obligation is subject to a fine. Section 83(2) of the Customs Act defines the power of the customs or tax authorities to detain such amount of money in excess of 15,000 EUR/US and empowers the authorities to detain the money if it is suspected to be derived from or will be used for a violation of the Criminal Code. Money laundering and the financing of terrorism are offences included as violations of the Criminal Code.

421. There is an obligation to declare not only cash but also negotiable instruments. The authorities have indicated that the definition of "money etc" in section 23(4) includes cash, travelers cheques and other monetary instruments such as securities. Precious metals and gold are declarable goods under section 25(3) of the Customs Act.

422. Customs and tax administration are responsible for the administration and implementation of the 
system. The system operates through spot checks made by the authorities on incoming and outgoing travelers and also on inspection of mail being sent which it is suspected may contain cash or similar values. The obligations apply to EU citizens also and there are regular spot checks carried out on such citizens. Police authorities, at the request of customs and tax officers, have power to ask for information relating to the origin of the money whether the money is based upon a declaration or found without the required declaration. The system works for both incoming and outgoing cash transportation. The majority of controls relate to outgoing movement although there are no statistics to that effect. Where a person who is stopped and checked declares that the assets belong to a third party, information is sought about the third party.

423. Some guidance has been provided customs and tax officers to familiarize them with the obligation. For example, the TAX guidelines refer to the definition of "money etc" as including the types of monetary instruments described in paragraph 422 above. However, there are no indications that specific practical instructions have been issued to the officers at ground level to guide them regarding to how to implement the system.

424. All declarations, non-declarations, false declarations and instances that raise a suspicion of ML or FT are forwarded to the FIU. The authorities indicate that the detention of money as a result of non-disclosure or false declarations are carried out by the customs/Tax under section 83(2) of the Customs Act and thereafter, seized by the police in accordance with the seizure system prescribed in Chapter 74 of the AJA. Confiscation can only take place in accordance with the general provisions of the Criminal Code. If based upon inquiries or for other reasons there is any suspicion, the police is informed first and the FIU shortly after. Police officers are called in and the money or other covered items detained may be seized for the purposes of investigation. Guidelines and procedures have been prepared by the Copenhagen police to that effect.

425. Although Section 79 of the Customs Act provides for a fine in cases of non-declaration or false declaration, none have been applied to any of the violations to date, which raises questions about the effectiveness of the system. The authorities estimated that a fine of 500 to 1500 kroners was the probably range that would be levied in the case of a violation involving lack of knowledge of the requirement.

426. Between 2004-2005, there have been about 150 cases of non-declaration and 50 cases of suspicious declarations involving transportation of cash, out of which 160 cases were for the years 2004-2005. The 160 cases involved an amount of 19 million DKK for 2004 and 29,3 million DKK for 2005. Since 2002, 79 matters involving non-declaration or false declaration that were referred to the FIU, A total amount of DKK 7,6 million (EUR 1 million) was seized. In every instance, money was returned. There have been no prosecutions.

427. Information on the amounts and the identity of the bearer in cases of false declarations or suspicions is collected by customs and sent to the FIU on the basis of the provisions of sections 27 and 28 of the Public Administration Act. Such false or incorrect declarations or other situations where there is suspicion of ML or FT, are registered with all personal information, including ID, time, amount, nationality, destination and explanations with the TAX and the FIU. It is not clear whether the customs and tax authorities are attempting to organize efforts on the basis of false declarations or non-disclosure or some combination of both.

428. There appears to be significant under-declaration as authorities indicated that only a limited number of declarations had been made. True declarations of sums over the threshold are also sent to the FIU, but ID data concerning the bearer is not maintained in a data base system. This means that the authorities have no way of ascertaining whether an individual has made numerous declarations in a given period of time and whether such a person has been the subject of an earlier inquiry or investigation at the border for carrying money etc.. The authorities indicate that the absence of such a system is due to the lack of any legal basis. Such information, according to them, is registered with the Police. There is also general registration of personal information, on the basis of a written report which is filed with TAX.

429. Customs and Tax authorities and the police and the FIU collaborate and the police authorities are 
available to the customs officials at their request. As noted by the authorities, there is some cooperation within the EU and the Baltic Sea and Danish customs and tax authorities cooperate with foreign counterparts. There is no indication, in cases of unusual cross-border movement of gold, precious metals or precious stones, that the Customs Service or other competent authorities of the countries from which those items originated and/or the countries to which they are destined, are informed accordingly.

\section{Recommendation 32}

430. The statistics provided during the course of the mission indicate that there have not been any cases of false declarations and that, between 2002-2004, there have been 150 cases of non-declaration and about 50 with suspicious declarations. All cases except clear minor tax cases have been sent to the FIU and, for the years 20042005, the FIU has registered 83 declarations as STRs from customs and TAX out of which 79 are nondeclarations and 4 with declared amounts. It would be helpful to record statistics in such a way that the history of a particular matter can be easily monitored and for the FIU or the investigation authority to be able to benefit from such information.

431. Regarding declarations, such forms are sent to the FIU. However, the FIU is not able to store and record information relating to declarations made. It may only input information into its systems in the case of suspicions. Although it appears the FIU holds the records, it appears they are not maintained in a way such that information is usable or accessible. The absence of any organized and structured system regarding pertinent information means the collection effort results in few useable results.

\section{Recommendations and comments}

432. There should be practical guidelines for customs officers on how to implement the system, including more practical and precise information regarding the exact instruments in addition to monies that are subject to the declaration obligation.

433. Authorities should consider goals and strategies for the program and methods to encourage a greater level of compliance and improved levels of detection.

434. Sanctions should be used and appropriate fines be imposed to ensure compliance.

435. There should be system to check for previous history of persons involved in non-declaration or false declarations.

436. The customs and tax authorities and the FIU should work in closer collaboration regarding the implementation of the obligation.

437. Policies and practices regarding detentions and seizures of monies should be reviewed to determine why all monies have been returned.

438. There is a need to reinforce the system whereby all information relating to the evolution of any particular cross-border investigation is recorded for intelligence and investigation purposes.

439. Efforts should be undertaken to maintain declaration records in a way such that information is organized and readily usable.

Compliance with FATF Recommendations 


\begin{tabular}{|c|c|c|}
\hline SR.IX & PC & $\begin{array}{l}\text { - There is a need for practical guidance and instructions for line officers } \\
\text { making the cross-border checks and implementing the declaration system. } \\
\text { - Effectiveness concerns based on the low number of declarations } \\
\text { - No fines have been imposed in cases of non-compliance, } \\
\text { - Declaration form information though sent to the FIU is not organized and } \\
\text { made readily usable. }\end{array}$ \\
\hline
\end{tabular}

\section{Preventive Measures-Financial Institutions}

\subsection{Risk of money laundering or terrorist financing}

\section{Description and analysis}

440. Under the previous MLA, the scope of application of the preventive measures was prescribed both institutionally and functionally, mirroring the coverage of the First and Second European Directives on Money Laundering. As such, the previous MLA did not extend to life insurance intermediation. There was no authority under the MLA for excluding a sector or service from the coverage of the Act or for reducing the extent to which measures would apply. Moreover and while covered by the MLA, credit card, factoring, leasing and finance/consumer credit companies, as well as currency exchangers were not supervised for compliance with AML/CFT, although the authorities do not appear to have taken ML/TF risk into account.

441. The current MLA extends the coverage of the Act to life insurance intermediation and subjects credit card, factoring, leasing and finance/consumer credit companies, as well as currency exchangers to registration and supervision. There is some scope for excluding by regulation sectors and services from the application of the MLA but this is limited to situations where the European Commission may so decided pursuant to Article 40(1)(d) of the Third Directive (i.e., determine whether an exemption from the application of the Directive is justified on the grounds that persons are carrying out a financial activity on an occasional or very limited basis). There are no other grounds for excluding sectors or services from the application of the law.

\section{Customer Due Diligence \& Record Keeping}

\subsection{Customer due diligence, including enhanced or reduced measures (R.5 to 8)}

\section{Description and analysis}

442. The preventive measures for financial institutions are set forth in the Act on Measures to Prevent Money Laundering and Financing of Terrorism (Law no. 117 of February 27, 2006). Originally enacted in 1993 to implement the first EU AML Directive, the Act has been amended several times (the most significant changes introduced regarded the extension to TF of the AML requirements); a new version to implement the provisions of the third EU Directive on AML/CFT and the revised FATF Recommendations, entered into force on March 1, 2006, during the evaluation mission. Further to the previous Act the Danish Bankers Association issued in August 2003 "Guidelines on measures against money laundering and terrorist financing”. The guidelines have been updated to take into account the provisions of the new act and were distributed to all Danish banks on March 3, 2006, as "Preliminary guidelines on measures against money laundering and terrorist financing". These preliminary guidelines will serve as interim guidelines until a complete set of guidelines - which will take also into account some of the requirements that will enter into force on January 1, 2007. The Guidelines apply only to the banking sector and are not binding or enforceable.

443. The analysis of the legal framework will be also refer to and based on the explanatory notes to the 
new MLA. In Denmark, bills are accompanied by explanatory notes when presented to the Danish Parliament, Folketinget. IN the Danish system explanatory notes, besides responding to the need of providing clarification to the parliamentarians and to ensure that the general public has a chance of acquainting themselves with the bill and understanding it, play also an important role as a source of law when administrative and judicial authorities interpret the text of an act. Explanatory notes are thus a recognised source of law and they are used widely by Danish courts when interpreting rules of law.

444. While the coverage of previous act was already quite comprehensive, encompassing both financial and non financial sectors as defined by the FATF, The Act redefines the AML/CFT obligations introducing and regulating, inter alia, matters such as beneficial owner, enhanced and simplified CDD requirements and some elements of a risk based approach. However, as indicated above, some of these provisions will only enter into force January 1, 2007.

445. The new MLA is not yet applicable in Greenland and in the Faroe Islands. The 1993 MLA - which, for the financial sector, provided basic requirements for identification, record keeping and reporting of suspicious transaction for ML - was made applicable to Greenland in 1996 and to the Faroe Islands in 1997.

\section{Recommendation 5}

446. The coverage of financial institutions as defined by the FATF is comprehensive. According to sec. 1.1. the Act applies to the following financial institutions:

1) Banks.

2) Mortgage-credit institutions.

3) Investment companies.

4) Investment management companies.

5) Life assurance companies and lateral pension funds (nationwide occupational pension funds).

6) Savings undertakings.

7) Electronic money institutions.

8) Insurance brokers, when they act in respect of life assurance or other investment-related insurance activities.

9) Foreign undertakings' branches in Denmark, carry out activities under nos. 1-8.

10) Investment associations and special-purpose associations, collective investment schemes, restricted associations, innovation associations and hedge associations.

11) Undertakings and persons that commercially carry out activities involving currency exchange or transfer of money and other assets.

12) Other undertakings and persons that commercially carry out one or more of the activities mentioned in annex 1, that is:

a) Acceptance of deposits and other repayable funds.

b) Lending, including

i) consumer credit,

ii) mortgage-credit loans,

iii) factoring and discounting,

iv) financing of commercial transactions (including forfeiting).

c) Financial leasing.

d) Payment services (money transmission services).

e) Issue and administration of means of payment (e.g. credit cards, travelers' cheques, and bankers' drafts).

f) Guarantees and collateralization.

g) Trading for own account or for account of customers in:

i) money market instruments (cheques, bills, certificates of deposit, etc.)

ii) the foreign exchange market 
iii) financial futures and options

iv) currency and interest rate instruments

v) securities

h) Participation in issuing securities and provision of related services.

i) Advice to undertakings on capital structure, industrial strategy and related questions and advice, and services relating to mergers and the acquisition of undertakings.

j) Money broking.

k) Portfolio management and advice.

1) Safekeeping and administration of securities.

m) Safe custody services.

13) Danmarks Nationalbank (Denmark's central bank), insofar as it carries out activities corresponding to those of the institutions specified in no. 1

447. Danmark Post, which provides financial services on behalf of a major Danish bank, and undertakings which professionally carry out transport of money are no longer covered under the Act. Under the new Act, post offices and money-transport undertakings are subject to the AML/CFT requirements only if they "transfer money and other assets". According to the explanatory notes of the Act the expression "transfer of money and other assets" should be interpreted in accordance with note no. 4 to FATF Special Recommendation VI. According to this, transfer of money and other assets is a financial service in which, for example, an undertaking accepts cash, cheques, or other monetary instruments in one place, and pays a corresponding amount in another place, irrespective of how the transaction occurs.

\section{Anonymous accounts}

448. Although Denmark has no explicit provision or regulation prohibiting the existence of anonymous accounts, anonymous accounts are effectively prohibited by the customer identification requirements of the MLA and by tax legislation. The Act on Tax Management (Section 8H) provides that banks, stockbrokers and any other entity that accepts deposits with interest have to report every year to the tax authorities the name, address and personal registration number/ business registration number of each account holder.

449. According to Section 12.1 of the MLA financial institutions must require that their customers provide proof of identity when establishing business relationships with them, including the opening of an account or a safe custody. This requirement was established by sec. 4.1 of the previous Act, which entered into force on 1 July 1993 and covers all new customers since that date. Before then there were not clear obligations to identify customers when establishing business relationships or opening bank account. Section 40 of the former Act on Savings Banks and Commercial Banks (1930) provided identification requirements only in the case of opening a deposit account. The authorities explained that they could not exclude in principle the existence of accounts, established before 1993, which could be anonymous (and with reference to this point the explanatory note make clear that identification will have to be undertaken "if there are existing anonymous accounts or accounts under another name than the account owner, which were established before the Act entered into force, or if such accounts exist otherwise"), however this would appear to be an hypothetical case. According to the banks interviewed and to the FSA there are no anonymous accounts, nor there is any practice of numbered accounts, which are therefore not provided in Denmark.

When CDD is required

450. The MLA requires financial institutions to undertake CDD measures in the following circumstances:

- when establishing business relationships with the customers, including the opening of an account or a safe custody (section 12.1);

- in the case of occasional customers, for each transaction whose value is of EUR 15.000 or more. In this case the identification requirement applies irrespective of whether the transaction is completed in one or more related operations, if these appear connected (section 14.1); 
- if there is a suspicion that the transaction is associated with ML or FT covered by the reporting obligation (section 11);

- in the case of doubts about the veracity or adequacy of previously obtained customer identification data (section 12.6.);

451. The current Act does not provide identification requirements in the case of wire transfers, under the circumstances covered by SR VII. As such they are treated as occasional transactions for which identification is only required if EUR 15.000 or more.

452. The identification requirements required in the establishment of a business relationship and the opening of a bank account in the case of occasional customers and in the case of suspicion of ML and TF were already provided for in the previous Act (and therefore relevant requirements are also applicable in Greenland and the Faroe Islands, with reference to ML only). The identification requirements in the case of doubts about veracity/adequacy as mentioned under 4) were introduced by the new Act.

453. The obligation to identify in the case of suspicion of ML or TF is a general requirement, which must be applied irrespective of whether the customer relationship is permanent or occasional, the amount, etc. Therefore, the exemptions from the identification requirements set forth in the act (sections 20 and 21, described later on) cannot be applied in these circumstances. Consequently, in the case of suspicion of ML or TF, the obligation to identify applies also in the case of occasional customers where the transaction is less than EUR 15,000 .

\section{$\underline{\text { Required CDD Measures }}$}

454. All citizens and residents in Denmark are registered in the National Civil Register and have a CPR number (civil registry number) The CPR is made of 10 digits (the first 6 digits indicate the date of birth and the last 4 are the numbers that uniquely identify all people living in Denmark). The CPR number is used for registration and personal identification, and is a unique identifying number for each individual used as universal identification registration. Each business that is registered in the Central Business Register (CVR) is also assigned a number for registration purposes.

455. According to the language of the previous and the current Act the obligation for financial institutions to identify the clientele consists of the obligation to require that their customers provide proof of identity ("kraeve at deres kunder legitimerer sig").

456. There is no direct requirement to use reliable and independent identification data in verifying the customer's identity, nor is there an indication of the types of documents which are to be verified during the identification process. The explanatory notes, however, clearly set out that it is the responsibility of the covered institutions to obtain certain proof of the customer's identity, which must be confirmed with the necessary documentation. Furthermore the notes explain that "proof of identity" comprises identification of the customer as well as checking the relevant information concerning the identity using reliable identity documentation. In clarifying this point the explanatory notes recall Article 7 of the EU Third Directive, which states that checking the identity of a customer should be on the basis of documents, data or information obtained from reliable and independent sources. The new Guidelines issued by the Bankers Association also indicate that the information concerning identity must be checked on the basis of reliable identification documents. Similar provision, however, was not contained in the Guidelines issued in 2003.

457. According to the Act, in the case of natural persons (section 12.2) proof of identity will include name, address, the national registration number (CPR number) or similar documentation if the person in question does not have a CPR number; whereas in the case of legal persons (section 12.3) the proof of identity will include 
name, address, business registration number (CVR number) or similar documentation if the undertaking does not have a CVR number. As mentioned later on (see para. 462) there is no requirement to verify, in the case of a legal person, that the individual purporting to act on behalf of the legal person is so authorized nor to identify and verify the identity of that person.

458. The explanatory notes indicate that the amount of documentation required for adequate proof of identity of a customer, be it a natural person or an undertaking, will depend on a specific assessment of the relevant case. In the case of persons who are not resident in Denmark, the notes indicate as an alternative to a CPR number the passport number combined with information about date of birth and place of birth (birth data), or a similar unequivocal identification number combined with this birth data. In the case of an undertaking which is not registered in Denmark the notes explain that the "similar identification" (to the CVR) can be "another type of identifiable registration number".

459. For the banking sector (not applicable to other financial institutions) the (non binding) Guidelines issued by the Bankers Association (both previous and current version) indicate the kind of documents that should be preferred in the identification process. There is no recommendation to rely solely on photographic identification documents, although the new Guidelines acknowledge that photographic identification is a safe way of identifying customers. the following identification documents are recommended:

1) with photographs

- EU driver's license

- Valid passport

- ID cards issued by Danish banks

- Other officially recognized ID cards

- Identity card from the Danish Defense

- NATO passport

- Passport receipt (blue card with photo)

- Police identification card

- Press card

2) or without photograph, but with the CPR number (with the exception of the students card):

- Danish national health service card (with CPR number)

- Certificate of baptism/name (with CPR number)

- Tax card (with CPR number)

- Student card.

460. For the documents listed under 2, while the CPR number can be correlated with the National Register of Persons to confirm the name and the address, this is not however sufficient to prove that the person is the true owner of the document, as acknowledged by the new Guidelines. In the case of a student card there is not even a reference to the CPR. The guidelines indicate that in these cases it is the responsibility of the bank to determine whether the identity of the customer corresponds to the one of the bearer of the document, based on a risk assessment.

461. "Undertakings" are defined under section 3.2 as "companies and other similar legal arrangements". According to the Explanatory notes "legal arrangements" would refer to foreign forms for undertakings and associations which are not known in the Danish legal system, such as trusts. In this respect the obligations of the MLA to identify the beneficial owner also apply in relation to customers from outside Denmark (therefore also to trusts, as we will see. In the case of "undertakings" proof of identity must include name, address, business registration number (CVR number) or similar documentation if the undertaking does not have a CVR number (section 12.3). However there is no requirement in the law to verify, in the case of a legal person or arrangement, that the individual purporting to act on behalf of the legal person or arrangement is so authorized nor to identify and verify the identity of that person. Authorities assert that this occurs in practice. Section 12(3) also requires that financial institutions take reasonable steps to ascertain the ownership and control structure. The explanatory 
notes indicate that this should be interpreted as a requirement to "obtain information about the legal form of the customer, the controlling interests, management, and provisions regulating the powers to bind the customer".

462. The guidelines issued by the Danish Bankers Association for the banking sector (both previous and current version) indicate the kind of documents that should be preferred in the identification process of legal persons, based on various circumstances (i.e., whether the company is registered or not with the DCCA; associations and funds that do not have CVR; sole proprietorship; companies registered outside Denmark; foreign companies that are not registered abroad). These are:

A) In the case of limited companies and limited liability companies and limited liability undertakings, corporate funds and associations which are registered with the Danish Commerce and Companies Agency, the identity information indicated should include:

- The name of the company/association

- CVR number

- Address, including postal address

It is optional to require a summary of registration (which should be no more than a year old) from the DCCA, where the names of the board of directors and the board of management as well as regulations governing the powers to sign for the company are indicated.

B) In the case of companies and associations that are not registered with the DCCA, but who have a CVR number from the Central Customs and Tax Administration, the identity information must include:

- The name of the company/association

- CVR number

- Address, including postal address

- Names, including CPR numbers, of members of the board of directors and/or executive managers

- Articles of association including regulations governing the powers to sign for the company

It is optional to require the current transcript from the Central Business Register with name and CPR number of the fully liable members.

C) In the case of associations and funds that do not have a CVR number the identity information must include:

- The name of the association or fund

- Names of the management and/or executive manager, indicating CPR numbers

- Articles of association including regulations governing the powers to sign for the company

It is optional to require:

- A copy of the articles of association

- Minutes from the general meeting or memorandum of association including names and CPR numbers of the management, signed by the founders or the entire board of directors and confirmed by the chairman or the company's lawyer.

D) In the case of sole proprietorships the identity information must include:

- The name of the person and the undertaking

- CPR and CVR numbers

- Address, including postal address for both the person and the undertaking

It is optional to require: 
- Proof of identity including CPR number as in the case of natural persons.

E) In the case of companies registered outside Denmark, a transcript about the company, possibly certified, may be obtained from the foreign official registration office. In case of doubt about the authenticity, the transcript may be submitted for certification with the local Danish consulate or the company's bank.

F) In the case of foreign companies etc. that are not registered with a foreign register, the information required is the same as in the case of associations and funds that do not have a CVR number; this information may be submitted for certification with the local Danish consulate or the company's bank.

463. While these requirements - which are not mandatory and are targeted to the banking sector - could be considered sufficient for the identification process of a legal entity; they are not per se enough for the process of ascertaining beneficial ownership in the case of legal companies/arrangements.

464. The previous MLA did not contain any obligation to identify the beneficial owner. The system appeared to be rather weak especially in the case of legal arrangements as there was no specific obligation to take reasonable measures to understand the control structure of legal arrangements nor to determine who are the natural persons that ultimately own or control the customer. While the guidelines issued by the Bankers Association in 2003 recommend that certain information be obtained in the case of legal arrangements they were not legally enforceable. Besides, those Guidelines made it clear that "there is no requirement that the bank must request proof of identity from the owners (shareholders etc.) behind the companies". However, the guidelines did highlight some special situations where the bank - as part of its compliance with the "know-your-customer" principle - would need to familiarize itself with the owners and the ownership structure behind the company, such as in the case of foreign companies from e.g. politically unstable countries, countries with high crime rates or less developed countries.

465. The new Act sets forth provisions regarding the identification of beneficial owners. The beneficial owner is defined in section 34 ), according to the definition included in the third EU directive as:

"The natural persons who ultimately own or control the customer or the natural person on whose behalf a transaction or activity is being conducted, including:

a) Persons who ultimately own or control a company through direct or indirect ownership or control more than 25 per cent of the ownership interests or the voting rights in the company, except companies the ownership interests of which are traded on a regulated market.

b) Persons who otherwise exercise control over the management of a company.

c) Persons who, according to the articles of association of a fund or in another manner, are to receive 25 per cent or more of the distribution funds from a fund or another similar legal arrangement or other property, if the persons are known.

d) The group of persons, in whose main interest a fund or another similar legal arrangement has been set up or operates.

e) Persons who exercise control over 25 per cent or more of the distribution funds from a fund or another similar legal arrangement or other property".

466. According to the explanatory notes, the provision is based on a specific assessment of when a natural person can be deemed to have a controlling interest in an undertaking or in a legal arrangement which is a customer. The notes explain that controlling interest partly depends on the ownership of holdings/shares and voting rights as well as the undertaking's Articles of association and other agreements such as shareholder agreements and division of shares into classes; therefore the assessment on the beneficial owner should be carried out back to the one or more natural persons with ultimate control of the undertaking. If a natural person has a mortgage on the shares of an undertaking and if the voting rights linked to these shares follow the mortgage, then this person will also be the beneficial owner provided, on the basis of a specific assessment, these voting rights give a controlling interest.

467. The definition of the beneficial owner contained in the new Act transposes the standard set forth in 
the EU Directive (i.e., based on the $25 \%$ threshold that automatically determines the case of control in a company) as examples of situations of beneficial ownership, but which are not intended to be exhaustive. The explanatory notes clarify that the definitions contained in paras. a)-e) of the provision are only examples and leave space for a more substantial inquiry in ascertaining who the ultimate owner, which is not necessary based on the $25 \%$ threshold. In this respect the notes quote the case of a person who, for example, owns a smaller percentage of the capital of an undertaking, which could nevertheless also be deemed as a beneficial owner under the general definition of the Act, given the particular circumstances of the situation.

468. As mentioned, para. a) of section 3, 4) refers to the case of ownership or control of more than $25 \%$ of the ownership interests or the voting rights in a company as giving a controlling interest in the company. The provision in para. b) refer to the case of persons, other than in the circumstances set forth in para. a), who exercise control of the management of a company, as the case of persons with the right to appoint or remove the majority of the members of the company's board of directors or similar management body. Paras. c)-e) result from Article 3 (6) (b) of the Directive which lists examples of legal entities, such as foundations and legal arrangements, such as trusts which administer and distribute funds. The explanatory notes refer to these circumstances as being particularly relevant for trusts (i.e., foreign trusts, as trust is an institutions which is not known in Danish law). In the case in which the beneficiaries are not yet determined, it is sufficient, according to para. d), to note the group of persons in whose interests a trust or a Danish fund is established or acts. This again reflects the position of the Third EU Directive which, at recital 9, says that in the case of a foundation or trust, if the beneficiaries are yet to be determined and is therefore impossible to identify an individual as the beneficial owner, it would suffice to identity the class of persons intended to be the beneficiaries of the foundation or trust . With respect to foundations, according to the explanatory notes it is not relevant to focus on persons who are to receive more than $25 \%$ of the fund's property under para. c), because a foundation may only make distributions of its distributable reserves. Therefore it will be relevant to examine whether there are people who are to receive more than $25 \%$ of the foundation's distributable funds. Finally, with regard to para. e), persons who exercise control of at least $25 \%$ of the distributable funds of a Danish foundations will include the board of directors who manage the fund observing the objects of the fund and any provisions on distributions. In a trust, persons who exercise control of at least 25 per cent of the trust's property could also include the founder of the trust as the founder could also be the trustee.

469. There is not a direct and express obligation for financial institution to determine whether the customer is acting on behalf of another person and to take reasonable steps to obtain sufficient identification data to verify the identity of that other person, and the current requirement is too restrictive. In fact, section 15 is limited to circumstance where the covered entities have "knowledge or presumption that a person other than the one they are in contact with is the beneficial customer".

470. Section 12.3 of the Act sets forth the obligation to identify beneficial owner by stating that, "reasonable steps shall be taken to ascertain the undertaking's ownership and control structure and the undertaking's beneficial owners shall be identified". The obligation to identify the beneficial owner, however, does not apply when the beneficial owner has funds in a client's account of a notary or a lawyer, if the notary or the lawyer is subject to regulations corresponding to the MLA, upon the condition that information about the identity of the beneficial owner etc. is made available to the account-holding institution when said institution requests this (section 21(1). The provision does not specify the information or data required in the identification of the beneficial owner, nor does it refer to the verification process.

471. It remains to be seen how these provisions will be implemented. Guidance is likely to be needed. Moreover, the Danish Bankers Association guidelines are incomplete in regard to the identification of the beneficial owner. The Central Business Register (CVR, to which the Guidelines refer) does not contain information on beneficial ownership of companies. Information on public limited companies or private limited companies is available in the shareholder register. This register, which contains limited beneficial ownership information with respect to bearer share companies) is not accessible to the public. The only information publicly available upon request is, in the case of a public company, where any shareholder has reached the 5\% of the capital or of the voting rights and, in the case of a private company, in a situation in which all shares are held 
by a single shareholder.

472. There was no requirement under the previous Act for financial institutions to obtain information on the purpose and intended nature of business relationship. Section 12.4 of the new Act requires now financial institutions to obtain information about each customer's objective regarding the business relationship and the intended extent hereof.

473. There was no requirement under the previous Act regarding ongoing due diligence on the business relationship, nor was it required that the documents and data obtained during the CDD process be kept up-todate. Section 12.5 of the act now requires financial institution to monitor customer relationship and transactions on a regular basis and oblige them to keep up to date documents, data and other relevant information. The provision requires transactions undertaken throughout the course of said relationship to be monitored to ensure that the transactions being conducted are consistent with the undertaking's or person's knowledge of the customer and the customer's business and risk profile, including, where necessary, the source of the funds. However this provision will only enter in to force on January 1, 2007, and there are therefore no current requirements.

474. The previous Act did not provide any requirement for enhanced customer due diligence for higher risk customers, business relationships or transactions. Section 19 of the new Act sets forth enhanced due diligence requirements "in situations which by their nature can present a higher risk of money laundering and terrorist financing". According to the explanatory notes, the enhanced customer due diligence measures should be based on a risk assessment and should apply in situations which by their nature can present a higher risk of money laundering and financing of terrorism. Section 19 is to be applied, at minimum, in the following circumstances:

- for all financial institutions, where the customer has not been physically present for identification purposes,

- for banks, mortgage credit institutions and electronic money institutions in the case of cross-border correspondent banking relationships with banks and institutions from countries outside the European Union with which the Community has not entered into an agreement for the financial area

- for all financial institutions, in the case of non domestic PEP.

475. This provision is not currently in force. It enters into force on January 1, 2007. Despite the indication that these are only "minimum" requirements, there is a risk that financial institutions will focus largely on the above-prescribed higher risk circumstances. This is all the more so as there is no guidance (neither from the authorities nor from the Danish Bankers Association) as to what might constitute higher risk circumstances (e.g., non-resident customers, private banking, legal persons or arrangements such as trusts that are personal assets holding vehicles or to companies that have nominee shareholders or sharer in bearer forms as requiring enhanced CDD). (Requirements concerning non-face-to face transactions, correspondent banking and PEPs are addressed under the relevant Recommendations.)

476. Exemptions: Unless there is a suspicion of ML or TF, the identity requirements set forth in Sec. 12 of the Act and the Enhanced due diligence requirements set forth for the case of customers not physically present at the time of identification do not apply in some circumstances, on the assumption of a low risk of ML or TF. These are indicated in section 20.1. and 21.1 and 2 of the Act. According to section 20.1, CDD is not required in the case of:

- Life-assurance and pension contracts if the amount of the annual premium is equivalent to EUR 1,000 or less or, in the case of a single premium, if the amount of the single premium is equivalent to EUR 2,500 or less.

- Life-assurance and pension contracts entered into in pursuance of a contract of employment or the business of the insured party, provided the agreement does not feature a buy-back clause and cannot be used as collateral for a loan. 
- Life-assurance and pension contracts where the premium or the contribution is to be debited to the customer's bank account.

- In this case the requirement concerning proof of identity is regarded as met when it is ascertained that the premium or contribution from the pension saver is to be debited from an account opened in the name of the pension saver in accordance with the identification requirements set forth in section 12 .

- Life-assurance and pension contracts entered into in pursuance of a contract of employment or the business of the insured party with a limited buy-back clause, provided that proof of identity is given if the customer makes use of the buy-back clause.

- The explanatory notes indicate the event of emigration of the customer as an example of a limited buy-back clause.

- Electronic money, where the maximum amount stored on non-rechargeable cards cannot exceed EUR 150 , or where the maximum amount stored on rechargeable cards cannot exceed EUR 2,500 within one calendar year, and where a maximum of EUR 1,000 can be withdrawn within one calendar year.

477. The application of simplified due diligence also in the case of non face to face transactions in the above mentioned circumstances (section 20.1 exempts not only from the identification requirements set forth in section 12 but also from the requirements provided in the case of non face to face transactions by section 19.2) does not appear to be consistent with the international standard. Such a circumstance, in fact, does not meet the definition of low risk under criteria 5.9 of the Methodology, because non face to face transactions may present specific risks (and as such they are addressed by Recommendation 8) because authorities have not demonstrated these transactions are low risk.

478. According to section 21.1 and 2, the identity requirements do not apply also in the following circumstances:

a) if the customer is:

1) one of the financial institutions mentioned in sec. 1(1), nos. 1-11 (with the exception of the financial intermediaries mentioned in the annex 1 of the law) and the Danish Central Bank; or a similar undertaking with its registered office in a country within the European Union or a country with which the Community has entered into an agreement for the financial area covered by the Third Money Laundering Directive, or a similar undertaking established in a country outside the European Union with which the Community has not entered into an agreement for the financial area, subject to requirements to combat money laundering and terrorist financing corresponding to the requirements stipulated in the Third Money Laundering Directive, and if compliance with these requirements is supervised,

2) an undertaking the securities of which have been admitted to trading on a regulated market, or

3) a Danish public authority.

The first exemption from having to obtain proof of identity would not appear to be consistent with the FATF standard. FATF Recommendation 5 requires financial institutions to apply CDD measures, but allows them to determine the extent of this on a risk sensitive basis. Where the risks are low, it allows countries to decide that financial institutions can apply reduced or simplified measures. By exempting financial institutions from having to identify a customer that is a financial institution located in the EU or in a country in which the Community has entered into an agreement for the financial area covered by the Third EU Money Laundering Directive, the authorities are making an implicit judgment that 
such customers pose a low risk of money laundering and terrorist financing. However, the authorities acknowledged that they had conducted no such risk assessment vis-à-vis such customers, nor had they evaluated whether the countries where such customers are located are in compliance with and have effectively implemented the FATF Recommendations. As such, this exemption does not appear to be consistent with the FATF Recommendation 5.

b) when the beneficial owner has funds in a client's account of a lawyer, if the lawyer is subject to regulations set forth in the MLA, upon the condition that information about the identity of the beneficial owner etc. is made available to the account-holding institution when said institution requests this. This exemption does not appear to be in line with the FATF standard or Basel guidance on CDD because it is not limited to the case of "pooled accounts" and seems applicable also in the case of individual owned accounts or sub-accounts. The authorities have indicated an amendment to the provision limiting the exemption to pooled accounts only is expected to be passed by Parliament in the second half of 2006 .

479. According to subsection 3 information must always be obtained to ascertain that the customer is covered by the exemptions and the financial institutions are under the obligation to obtain sufficient information to ascertain that the customer is effectively covered by these exemptions. The FSA is granted with the power of exemption concerning other products, transactions or categories of financial institutions on the basis of decisions which might be taken by the European Commission.

480. The previous Act did not provide flexibility to adjust CDD on a risk sensitive basis. Section 12.7 of the new Act allows now the possibility to carry out the identification procedure (requirement of proof of identity, information on purpose of business and regular monitoring of customer relationship) on the basis of a risk assessment, depending on the risk related to the individual customer or business relation, the product or the transaction. In such a situation the financial institution is under the obligation to prove to the relevant MLA supervisory authority the adequacy of its investigation in determining the low risk of ML and FT. The need for guidance by the supervisory authority in the area of risk sensitive basis has been expressed by the interviewed financial institutions.

481. The explanatory notes make clear that even though section 12.7 allows for less a extensive proof of identity of customers on the basis of a risk assessment, it is not possible to use this to omit the obtaining of information on the name, address and CPR number mentioned under 12.2, as well as the information requested in the case of legal persons.

Timing of verification

482. Section 13 of the Act specifies that the identification procedure must be completed in connection with the establishment of the customer relationship and no later than before carrying out the transaction.

483. The MLA provides no possibility for completing the identification process after the required timing, which, in any event, has to take place before any transaction is executed. According to section. 13 of the MLA, provided that this is necessary to not interrupt the normal conduct of business, the identification procedure may, on the basis of a risk assessment, be completed in immediate continuation of the establishment of the customer relationship, in any case "as soon as practicable after the initial contact with the customer". The explanatory notes clarify that this provision should be interpreted conservatively. This provision can, for example, apply when a customer relationship is established without the customer appearing in person. In such situations the identification procedure should, however, be concluded as fast as possible following the first approach to the bank to establish a customer relationship. The customer relationship should also be such that, on the basis of an assessment of the risk of money laundering and financing of terrorism, it seems reasonable to postpone proof of identity. In any event, as already mentioned, section 13 prohibits the execution of the transaction before the identification procedure has been completed. 
484. An exemption is set forth in section 13.3., according to which life-assurance companies and pension funds may carry out proof of identity of the customer after establishment of the customer relationship. In this case, however, the proof of identity is required to take place at or before the time of payout or at the time the beneficiary intends to exercise rights vested under the policy.

485. The previous Act did not provide for any consequence for the failure to comply with the CDD requirements. According to section 13.2 of the new MLA a regular customer relationship or a business relationship must not be established, and transactions must not be carried out for a customer, if proof of identification cannot be carried out in accordance with the identification requirements set forth in sections 12.1-4 (identification obligation when establishing business relations, required identification data; obligation to obtain information on customer's objective and extent regarding the business relationship). According to the explanatory notes this provision applies irrespective of whether the reason for the lack of information is that the customer refuses to submit the information or whether there are other circumstances.

486. In such circumstance the financial institutions are required to "check" whether a "notification" is to be submitted to the FIU (however within the more stringent standards set forth in section 7, which now requires, for the reporting obligation, that the suspicion refers to an offence punishable by imprisonment of more than 1 year).

487. In the previous Act there was no requirement to apply CDD requirements to existing customers. According to Section 12.8 of the current Act financial institutions "at a suitable time and on the basis of a risk assessment" are now required to "carry out proof of identity" and "collection of information" when the information required by the CDD process "does not exist".

488. This requirement applies for customer relationships, which were established before the original Act entered into force on 1 July 1993. The requirement also applies for customers which the financial institutions established after 1 July 1993 who have not been subject to the requirements to undertake reasonable steps to ascertain the undertaking's ownership and control structure and to identify the beneficial owner.

489. The provision states that the identification process of the customers must be carried out at an appropriate time and on the basis of a risk assessment. According to the explanatory notes the reference to the risk assessment means that the risk of money laundering and financing of terrorism should be assessed for the individual customer or for the individual product; whereas the possibility for the identification procedure to be carried out at an appropriate time is meant to allow the financial institutions to integrate the process of identification "as part of the routine operations so that the greater administrative burden arising from the Act is minimized". The assessment of "at an appropriate time" should be therefore considered in connection with the greater administrative burden imposed by the Act on the undertakings and other persons it covers.

\section{Effectiveness}

490. The mission met with a large number and range of financial institutions and their respective associations. While the degree of awareness or concern about the risks of money laundering and terrorist varied from institution to institution, they all appeared to have put in place generally appropriate CDD policies and procedures. Banks appeared to have the most developed policies, procedures and controls. The Danish Bankers Association issued guidelines with respect to the previous MLA that contained extensive explanation of the MLA, guidance on what constitutes acceptable proof of identity for physical persons an different types of legal persons and arrangements, as well as on internet banking. These guidelines have been partially updated to take account of the provisions now in force under the new MLA. Guidelines prepared by other financial sector associations are far less comprehensive. While it is difficult to come to firm conclusion on the effectiveness of implementation of these measures, the FSA has found a higher frequency of non-compliance with CDD requirements than other requirements. That said, and as indicated later in the report, the suspicious transactions 
reporting regime does not appear to be effective, further improvements in the scope and frequency of inspections are required and there are shortcomings in the sanctions regime. Moreover, the new CDD elements of the law have only recently been introduced. Financial institutions are anxiously awaiting guidance from the FSA regarding the identification of beneficial owners and the risk-based approach generally. As such, it cannot be concluded that the CDD requirements have been effectively implemented.

\section{Recommendation 6}

491. The previous Act did not contain any provision regarding PEPs. PEPs are now addressed in the new Act; however the relevant provisions, which are described below, will only enter into force on January 1, 2007.

492. Section 3, 6) of the MLA defines PEPs as "Persons who are or have been entrusted with a prominent public function, persons connected to such persons through same-sex partnership, marriage or the children or parents of such persons as well as persons known to be close employees of said persons". "Known" is intended as generally known to the public. While the definition is consistent to FATF standard there is a slight difference due the fact that "close associates" of PEPs are not mentioned, whereas the definition refers to "close employees" of PEPs. The authorities explained that they have referred to the definition contained in the third EU directive. Apparently the term "close associates", which is also indicated in the Directive, has been translated as "employee" in the official Danish version of the Directive, which is the one which was referred to in the drafting of the Act.

493. The explanatory notes further clarify that the definition of PEP includes heads of state, such as presidents and ministers, members of parliament, judges, high-ranking military personnel, state officials in leading positions, leaders of political parties, and members of the management of state-owned companies; and that it does not include persons with a prominent public function in regional bodies abroad corresponding to Danish municipalities and counties.

494. While the relevant provisions regarding PEPs require only that measures be taken with respect to non-residents, the explanatory notes clarify that the definition applies also to Danish politically exposed persons that are resident abroad. Moreover, the provision covers persons connected to such persons through a same-sex partnership, marriage or the children or parents of such people as well as people known to be close employees of these people. In determining whether or not the customer is a PEP, the notes also call for paying special attention to those jurisdictions known to be affected by widespread corruption.

495. The enhanced CDD requirements for PEPs, which will enter into force only on January 1, 2007, are set forth in section 19.4 of the new Act.

The provision requires financial institutions to:

- have sufficient procedures to determine whether the customer is a politically exposed person who is a resident of another country;

- have senior daily management approval for establishing business relationships with such customers,

- take reasonable measures to gather information about the sources of income and funds that are involved in the business relationship or transaction, and

- continuously monitor the business relationship.

496. There is no provision that requires senior management approval to continue already established business relationships with a PEP. While this could have been addressed in a regulation or in some other enforceable mean there is no reference in the Act to a provision empowering supervisory authorities to issue regulations regarding PEPs. At the time of the mission, the authorities informed the evaluators that this issue will be addressed in guidelines that supervisory authorities are generally empowered to issue under their area of responsibility. However, guidelines do not constitute enforceable means under Danish law. The authorities have since indicated that they have drafted an amendment to the MLA that will enable the FSA to issue executive 
orders concerning the definition of a PEP. The amendment is expected to be passed by parliament in the second half of 2006.

497. The enhanced requirements for politically exposed persons only apply to those who reside outside Denmark. The determination as to whether the procedure to determine if a customer is a PEP is sufficient will depend on the size of the undertaking. For very small undertakings, there will be no requirement for written procedures. Larger undertakings, however, must have written procedures, according to the explanatory notes. "Senior daily management" should be interpreted as the person or department that is on the immediate higher level of the hierarchy of the employee seeking approval to enter into an agreement with the customer. In smaller institutions, it will often be the board of management that is to grant the approval.

498. The obligation to ensure continuous monitoring of the business relationship is interpreted by the explanatory notes "so that changes to the extent and the size of transactions will be discovered and investigated further."

\section{Additional elements}

499. Danish PEPs are covered only to the extent that they reside abroad. Denmark has signed but not yet ratified the UN Convention against Corruption.

\section{Recommendation 7}

500. Cross border correspondent banking was not addressed in the previous Act, nor in the 2003 Bankers Association guidelines. The new Act (section 19.3) sets forth enhanced CDD requirements in this area, only in relation to cross-border correspondent banking relationships with banks and institutions from countries which are not members of the EU or with which the Community has not entered into an agreement for the financial area (EEA). According to these requirements - which enter into force in January 1, 2007 - banks, mortgage-credit institutions and electronic money institutions, before establishing new correspondent banking relationships, will be required to:

- gather sufficient information about a respondent institution to understand fully the nature of the respondent's business and to determine from publicly available information the reputation of the institution and the quality of supervision,

- $\quad$ assess the counterparty's anti-money-laundering and anti-terrorist-financing controls,

- $\quad$ obtain approval from senior daily management ;

- $\quad$ ensure that the correspondent bank has checked the identity of the customers and is regularly assessing relevant information about the customers having direct access to the account of the correspondent bank with a person or undertaking covered by the MLA, and ensure that the correspondent bank is able to supply relevant customer information at the request of the account holder.

501. There are some inconsistencies with FATF requirements, which are partly due to the way the obligation is set forth in the EU directive (see article 13.3 of the Directive). In the Danish Act the obligation for the correspondent institution to gather sufficient information in order to determine the reputation of the respondent institution and the quality of supervision does not specifically mention the obligation to determine whether the respondent institution has been subject to a ML or TF investigation or regulatory action. The explanatory notes are silent on this point. While there is an obligation for the correspondent institution to assess the respondent institution's AML/CFT controls there is no obligation for the correspondent institution to ascertain that these controls are adequate and effective. Although a requirement under the EU Directive (see article $13.3 \mathrm{~d}$ ) there is no reference, either in the law, as in the explanatory notes, to the obligation to document the respective AML/CFT responsibilities of each institution. The authorities suggest that it is implicit that banks will document each institution's responsibility, but this is of concern as there is no enforceable obligation and the FSA has yet to apply its stricter interpretation of this provision in the course of its supervisory program. 
502. With respect to "payable through" accounts, sub-section 19(3)4) of the MLA requires that a) the respondent institution has verified the identity of the customer and performed on going due diligence on the customer, having direct access to accounts of the correspondent and b) the respondent is able to provide relevant customer identification data upon request to the correspondent bank. 10

\section{Recommendation 8}

503. Requirements regarding non-face to face business relationships or transactions have been introduced in the new Act as part of the enhanced CDD measures. They enter into force only on January 1, 2007.

In the case of the customer who has not been physically present for identification purposes the Act requires the taking of "further measures to ascertain the customer's identity" The provision sets out an illustrative list of measures that can be taken to ascertain the customer's identity in these situation, such as:

- Ensuring that the customer's identity is established by additional documentation.

- Checking or verifying the documents supplied, or requiring confirmatory certification by some other financial institution

- Requiring that the first payment in connection with the transactions is carried out through an account opened in the customer's name with a bank.

504. The provisional Guidelines issued by the Bankers association contain also specific provisions for the case of an account opened on the internet, via mail, also in the case of customers residing abroad. However, there is no specific enforceable regulation or guidance regarding the need for internal policies within financial institutions to prevent the misuse of technological developments in money laundering or terrorist financing schemes.

\section{Recommendations and comments}

505. Denmark should extend the applicability of the new MLA to Greenland and the Faroe Islands.

506. The identification requirements should be aligned to take also into account the circumstances set forth by SRVII in the case of wire transfers.

507. There should be an indication (either in a regulation or by guidance from the authority) of the types of documents which are to be verified during the identification process.

508. An assessment should be made of whether or not individual countries of the EU or those with which the Community has entered into an agreement for the financial area are in compliance with and have effectively implemented the FATF Recommendations, for purposes of exempting from proof of identity customers that are financial institutions located in these countries.

509. In the case of a legal person the law (or a regulation) should require verification that the individual purporting to act on behalf of the legal person or arrangement is so authorized and should require the identification and verification of the identity of that person. Guidance should be provided concerning the verification of identity of legal arrangements such as trust

510. There should be a general clear requirement for financial institution to determine whether the customer is acting on behalf of another person and an obligation to take reasonable steps to obtain sufficient identification data to verify the identity of that other person. 
511. In addition to the existing obligation to identify the beneficial owner there should also be an obligation to verify the identity of the beneficial owner, and a specification of the information or data required in this process.

512. The exemption of the CDD requirement in the case in which the beneficial owner has funds in a client's account of a notary or a lawyer should be limited to the case of pooled account only.

513. Supervisory authorities are encouraged to issue guidance on the risk sensitive approach.

514. In the case of PEPs, there should be a requirement to obtain senior management approval to continue already established business relationships with a PEP.

515. The Act should empower supervisory authorities with the responsibility to issue regulations in the area of PEPs.

516. There should be provisions to require financial institutions to document the respective responsibilities of the correspondent and respondent institutions and determine if the respondent bank has been the subject of an ML or FT investigation.

517. Close associates of PEPs should be considered to have risks similar to that associated with PEPs.

\begin{tabular}{|l|l|l|l|}
\hline Compliance with FATF Recommendations \\
\hline R.5 & PC & $\begin{array}{l}\text { Summary of factors underlying rating } \\
\text { The new MLA is not yet applicable in Greenland and in the Faroe } \\
\text { Islands, which remain subjects to the 1993 MLA. }\end{array}$ \\
$\begin{array}{l}\text { There are no identification requirements in the case of wire transfers } \\
\text { under the circumstances covered by SR VII (i.e., the identification } \\
\text { requirements apply only in the case of wire transfers of } 15.000 \text { EUR or } \\
\text { more). }\end{array}$ \\
$\begin{array}{l}\text { There is no indication of the types of documents which are to be verified } \\
\text { during the identification process. }\end{array}$ \\
$\begin{array}{l}\text { In the case of a legal person, there is no requirement to verify that the } \\
\text { individual purporting to act on behalf of the legal person or arrangement is } \\
\text { so authorized nor to identify and verify the identity of that person. }\end{array}$ \\
$\begin{array}{l}\text { The conditions under which a financial institution is required to determine } \\
\text { whether the customer is acting on behalf of another person and to take } \\
\text { reasonable steps to obtain sufficient identification data to verify the } \\
\text { identity of that other person are too restrictive (this is required only if the } \\
\text { institution has "knowledge or presumption"). }\end{array}$ \\
$\begin{array}{l}\text { In the case of beneficial owner there is no specification of the information } \\
\text { or data required for identification, nor is there a clear obligation of } \\
\text { verification. }\end{array}$ \\
$\begin{array}{l}\text { The requirements regarding ongoing due diligence and all those related to } \\
\text { the enhanced due diligence are not currently applicable (they will enter } \\
\text { into force as of January 1, 2007). }\end{array}$ \\
\hline
\end{tabular}




\begin{tabular}{|c|c|c|}
\hline & & $\begin{array}{l}\text { - No assessment has been underetaken of whether or not individual } \\
\text { countries of the EU or those with which the Community has entered into } \\
\text { an agreement for the financial area are in compliance with and have } \\
\text { effectively implemented the FATF Recommendations, for purposes of } \\
\text { exempting from proof of identity customers that are financial institutions } \\
\text { located in these countries. } \\
\text { - The exemption from the CDD requirement in the case in which the } \\
\text { beneficial owner has funds in a client's account of a notary or a lawyer is } \\
\text { not limited to pooled account but applies also to individual accounts. } \\
\text { - The simplified due diligence requirements applied in the insurance sector } \\
\text { also in the case of customers who are not physically present at the time of } \\
\text { identification (set forth in the ambit of the exemption from the CDD } \\
\text { requirement applying in low risk situations) do not appear to be consistent } \\
\text { with the international standard because they are not supported by an } \\
\text { evaluation of low risk of ML. } \\
\text { - Since the new CDD requirements either have only entered into force } \\
\text { recently or will enter force on January 1, 2007, it cannot be concluded that } \\
\text { the CDD requirements have been effectively implemented. }\end{array}$ \\
\hline R.6 & $\mathrm{NC}$ & $\begin{array}{l}\text { - The provisions regarding PEPs are not currently applicable. (They will } \\
\text { enter into force as of January 1,2007). } \\
\text { - } \quad \text { Although not a factor underlying the rating, the following should be } \\
\text { noted: } \\
\text { There is no requirement to obtain senior management approval to continue } \\
\text { already established business relationships with a PEP. }\end{array}$ \\
\hline R.7 & $\mathrm{NC}$ & 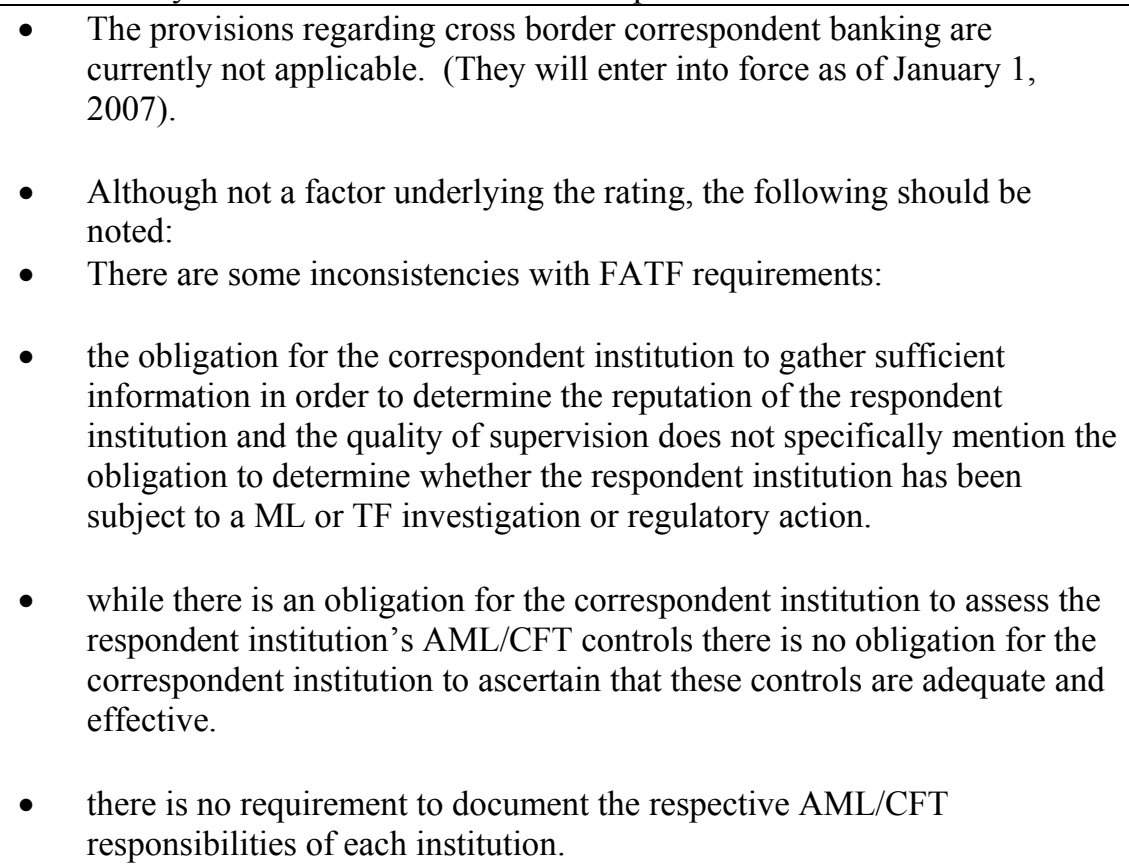 \\
\hline $\mathbf{R . 8}$ & $\mathrm{NC}$ & - The requirements set forth for non-face-to face transactions are not \\
\hline
\end{tabular}




\subsection{Third parties and introduced business (R.9) \\ Description and analysis}

currently applicable. (They will enter into force as of January 1, 2007).

518. The previous MLA did not provide the possibility to rely on third parties to perform the CDD process. The 2003 Guidelines issued by the Danish Bankers Association only refer to the case of a customer being an account holder in another company within the same group, in which case the proof of identity already obtained by one part of the group could have formed the basis for the customer relationship in other companies of the group, provided that these companies had full access to this information.

519. Section 17 of the new MLA now provides that institutions covered by the Act may rely on CDD conducted by third parties based on certain conditions and only when the institution which is relied upon is a domestic financial institution - either an insurance broker, or a financial undertaking as defined by section 5 no. 1 of the FBA (banks, mortgage credit institution, investment company, investment management company or insurance company). This means that bureaux de change, money remitters and other financial intermediaries, as well as DFNBPs cannot be relied upon as third parties in the CDD process even though they are regulated and supervised for AML/CFT. Financial institutions (carrying out financial activities as those sets forth in sections 711 of the FBA) which are licensed in a EU country or in a country with which the EU has an agreement for the financial area can also be relied upon as in the case of domestic institutions.

520. FATF Recommendation 9 states that financial institutions should be required to satisfy themselves that the third party is regulated and supervised (in accordance with Recommendation 23, 24 and 29), and has measures in place to comply with, the CDD requirements set out in R.5 and R.10. While it may be a reasonable assumption to make that third parties that are domestic undertakings fulfill the above criteria, it is less so regarding third parties that are undertakings within the EU or a country with whom the Community has entered into an agreement for the financial area and as such this would appear to be inconsistent with the standard.

521. If the financial institutions are licensed by a non EU country they can only be relied upon only if they are subject to AML/CFT requirements similar to those sets forth in the Third EU Directive and that they are subject to supervision to ensure compliance with those requirements. While the financial institution relying upon a third party should be satisfied about these requirements being met, there is no sanction provided for failure to do so, notwithstanding the possibility that the CDD requirements set out in section 12(1)-(4) have been met.

522. According to the explanatory notes it is up to the undertakings and persons covered by the Act to assess whether a country outside the European Union with which the Community has not entered into an agreement for the financial area is subject to requirements corresponding to the requirements of the Third Money Laundering Directive, and to assess whether compliance with these regulations is supervised. No particular guidance has been provided.

523. Rather than placing an obligation on institutions which are relying on third parties to immediately obtain the necessary information concerning the CDD process (as required by the FATF standard), the Act (section 18) places the obligation on the undertaking that is being relied upon to provide CDD related information and to make immediately available the proof of identity upon request. This provision - which transposes article 18.1 of the Third EU Directive - is unenforceable in the case where financial institutions being relied upon are outside Denmark and therefore falls short of the FATF standard. In fact there is no obligation for institutions relying on third parties to take adequate steps to satisfy themselves that copies of the identification data and other relevant documentation relate to the CDD requirements will be made available from the third party upon request without delay; rather, section 18 would provide for the requested institution the obligation to send the relevant proof of identity and control such information. Again the obligation - based on Article 18.2 of the Directive (except for the obligation on the requested institution to control the information, which is not mentioned in the Directive) seems quite difficult to enforce.

524. In determining in which countries the third party that meets the conditions can be based, Denmark 
relies on the decision taken by the EC on the basis of article 40.4 of the Third Directive. According to this provision the EC can decide whether a country outside the EU does not have an effective AML/CFT framework and make it public.

525. Section 17.1. states clearly that the ultimate responsibility for meeting the CDD requirements lies within the institution relying on the third party.

\section{Recommendations and comments}

526. The obligation that is currently imposed on the third party to immediately obtain the necessary information concerning the CDD process should be redrafted to impose the obligation on the financial institution that is relying on the third party.

527. The MLA should provide an obligation for institutions relying on third parties to take adequate steps to satisfy themselves that copies of the identification data and other relevant documentation relating to the CDD requirements be made available from the third party upon request without delay.

528. Consideration should be given to introducing a requirement for financial institutions to satisfy themselves that a third party located within the EU or in a country with whom the Community has entered into an agreement for the financial area is regulated and supervised (in accordance with Recommendation 23, 24 and 29), and has measures in place to comply with, the CDD requirements set out in R.5 and R.10.Alternatively, the authorities should conduct a thorough assessment of the supervisory framework and of the CDD measures in place in the concerned countries where the third parties are located and limit the location of third parties to those countries that have satisfactory supervisory framework and CDD measures.

\section{Compliance with FATF Recommendations}

\begin{tabular}{|c|c|c|}
\hline & Rating & Summary of factors underlying rating \\
\hline R.9 & $\mathrm{NC}$ & $\begin{array}{l}\text { - The requirements concerning reliance on third parties are not practically } \\
\text { enforceable in the case where financial institutions being relied upon are } \\
\text { outside Denmark. Rather than placing an obligation on institutions which } \\
\text { are relying on third parties to immediately obtain the necessary } \\
\text { information concerning the CDD process (as required by the FATF } \\
\text { standard), the MLA places the obligation on the undertaking that is being } \\
\text { relied upon to provide CDD related information and to make immediately } \\
\text { available the proof of identity upon request. } \\
\text { There is no obligation for institutions relying on third parties to take } \\
\text { adequate steps to satisfy themselves that copies of the identification data } \\
\text { and other relevant documentation that relate to the CDD requirements will } \\
\text { be made available from the third party upon request without delay. } \\
\text { There is no requirement for financial institutions to satisfy themselves that } \\
\text { a third party located within the EU or in a country with whom the } \\
\text { Community has entered into an agreement for the financial area is } \\
\text { regulated and supervised (in accordance with Recommendation } 23,24 \text { and } \\
\text { 29), and has measures in place to comply with, the CDD requirements set } \\
\text { out in R.5 and R.10. }\end{array}$ \\
\hline \multicolumn{3}{|c|}{ 3.4 Financial institution secrecy or confidentiality (R.4) } \\
\hline \multicolumn{3}{|c|}{ Description and analysis } \\
\hline 529. & & iality rules are set forth in part 9 (sections $117-123$ ) of the FBA which \\
\hline
\end{tabular}


contains a broad restriction for financial institution to disclose or use confidential information obtained during the performance of their duties, unless for due cause. Due cause includes compliance to the AML/CFT requirements.

530. Financial secrecy is in fact lifted for purposes of compliance with the reporting obligation requirements set forth in section 7 of the Act. There is no reference to the power of the FIU to obtain additional information in the Act; the mission was informed that if it is a matter of incomplete information this can be obtained upon request, whereas in the case of additional information a court order would be necessary. Despite that, however, subsection 5 states that the Police can demand the reporting entities any information necessary for investigation of the case, in the framework of the regulations stipulated in the AJA ( therefore with a court order), with regard to "the information not included in the notification (the STR), according to the explanatory notes.

531. In addition, supervisory authorities are empowered to access the institutions they supervise for the information they require for carrying out their supervisory responsibilities, including the area of AML/CFT. Section 347.1 of the FBA requires the financial undertakings, e-money institutions and savings institutions to provide the FSA with such information as is necessary for the performance of its duties. A similar provision is contained in section 47.1 of the IMA with regard to insurance brokers; in section 119 of the Investment Associations Act with regards to investment companies. Under the new Act there is also an express obligation for the institutions supervised by the FSA or the DCCA to provide these authorities with any information needed for the exercise of their supervisory responsibilities under the Act or any related issued regulations. Both the FSA and the DCCA are also granted power to access to the institutions subject to the Act for gathering information purposes, without the need of a court order (section 34.4 and 31.4). Under the previous act the FSA did not need a court order to compel production or obtain access to a financial undertaking, emoney institution or savings institution, cf. section 3472 of the FBA; the DCCA was granted in 2005 the power to compel production or to obtain access to information with reference to a money remitter (which was the only institution supervised for AML/CFT purposes under the previous law).

532. Although the FSA and its employees are subject to a strict professional secrecy rules according to section 354.1 of the FBA, section 354.5 allows the sharing of information with other authorities under certain conditions. Among those the FSA is allowed to share information with "other public authorities, including the prosecution and the police, in connection with the investigations and legal prosecution of criminal offences covered by the Criminal Code or the supervision legislation", as well as financial supervisory authorities in foreign jurisdictions, if the information is needed to carry out their duties. If the case of non EU countries information can be shared on the basis of an international co-operation agreement, and provided that the recipients of said information are subject to a statutory duty of confidentiality similar to the one provided for the FSA

533. The sharing of information between financial institutions is limited by the general professional secrecy and confidentiality rules. The FSA would provide for the exchange of information only within the same group of financial institutions.

534. The new Act permits some sharing of information pursuant to section 27.4, 6 and 7. These provisions envisage the following situations:

- An undertaking covered by the Act can inform other undertakings belonging to the same conglomerate (defined by Article 2.12. of Directive 2002/87/EC as a group of undertakings consisting of a parent undertaking, its subsidiary undertaking and the entities in which the parent undertaking or its subsidiaries hold a participation, as well as undertakings linked to each other by a relationship within the meaning of Article 12.1 of Directive 83/349/EEC) that a suspicious transactions report to the FIU has been executed or is considered to be executed, or that the financial undertaking is investigating a suspicious transaction or will be investigating a suspicious transaction.

- A financial institution can send out the same information as mentioned above to other financial 
institutions conducting the same type of activities as the financial institution in question. This, however, is provided that certain conditions are met: (the person is a customer in both institutions, the institutions are subject to the same professional secrecy, and the information is only used in the fight against money laundering or terrorist financing)

535. For Danish financial institutions to share information with foreign financial institutions outside the $\mathrm{EU}$, the financial institutions must be subject to a similar AML/CFT regime as the Third Directive.

\begin{tabular}{|c|c|c|}
\hline \multicolumn{3}{|c|}{ Recommendations and comments } \\
\hline \multicolumn{3}{|c|}{ Compliance with FATF Recommendations } \\
\hline & Rating & Summary of factors underlying rating \\
\hline R.4 & $\mathrm{C}$ & \\
\hline
\end{tabular}

\section{Description and analysis}

\section{Recommendation 10}

536. Section 23 of the new act provides for the obligation of record keeping. An obligation to keep record of the information on proof of identity for 5 years after the termination of the business relationship as well as to keep records and document concerning transactions for the same period (after the performance of the transaction) was already present in the previous Act. The period of five years corresponds to the normal time for storage of accounting information pursuant to the requirements of the Bookkeeping Act, (Act no. 1006 of 23 December 1998).

537. There was a restriction under the Act on Processing of Personal data (confirmed by an opinion of the Data Protection Agency), with regard to copies of identification documents bearing pictures, which could have not be physically stored by reporting entities. The new provision allows expressly the institutions subject to the law also to store copies of the identification documents they have obtained during the CDD process (when establishing business relationships; in the case of occasional customers; when relying on third party and for the enhanced CDD requirements).

538. As in the previous provision the record keeping requirements apply regarding the identity information of customers (which must be maintained for no less than 5 years after the termination of the customer relationship) and for documents and records concerning transactions (which must be maintained for at least 5 years after the performance of the transactions). Since there is no obligation to identify in the case of wire transfers as defined by FATF, subsequently there is no record keeping for such a circumstance. There are some differences, though, with the previous act.

539. With regard to record keeping of transactions there is a new requirement - vis-à-vis the previous Act - of storing also the information relating to the newly established obligation (which will however enter into force as of January 1,2007 ) to pay special attention to complex or unusually large transactions. In this case the institution is required to investigate the purpose of such transactions and obliged to keep records of "such investigations" (section 6.2., recalled by section 23.2). Records and documents on transactions (including documentation on the investigations carried out pursuant to section 6.2. with regard to complex and unusual transactions) must also be stored "so that they can be located together". This requirement has been introduced to facilitate and expedite the provision of such information to competent authorities, and, according to the explanatory notes, is to be implemented with the aim of making it possible to match transactions with the identification data of the customer.

540. Finally, section 23.3. clarifies that the record keeping requirements should be fulfilled also in the case in which the undertaking has ceased its activities (including the case of dissolving as a result of bankruptcy). 
541. Competent authorities have access to such records in the forms described under Recommendation 4 (the FIU through a production of a court order).

\section{SRVII}

542. Section 16 on "Money transmission services" replicates the same provision contained in the previous Act and (partly) covers wire transfers. The provision in fact applies in the case of "transactions of payments carried out without personal contact between sender and intermediary or by an intermediary with which the sender does not hold an account" and is considerably narrower than called for by the standard in that it would appear to be:

- limited only to transactions that are "payments" (i.e. outgoing, but not incoming);

- not applicable in the case of wire transfers undertaken with a personal contact between sender and intermediary (therefore limited only to non-face-to face operations); and

- not applicable in a case of wire transfers where the sender holds an account with the intermediary.

543. In the circumstances set forth in section 16 there is a requirement that the transactions be at all stages accompanied by information about the sender, which is the information required in the identification of natural or legal persons. There is no reference to the obligation to obtain and maintain the originator's account number in the message or payment form. The effect of this is to some extent mitigated as information concerning the sender's CVR or CPR must be included. Section 16 requires also the intermediary to ensure that the information about the sender is adequate and meaningful. The penalty for non complying with these requirements is a fine, in the case of intention or gross negligence (section 37.1) or imprisonment up to 6 months in the event of "particularly gross" negligence or "extensive" intention.

544. These requirements do not apply to clearing and settlement systems carrying out payments between banks or between corresponding undertakings within the EU, nor do said requirement apply to systems for settlement of securities.

545. There is no distinction between cross border and domestic wire transfer, nor is there a de minimis threshold for the application of the provision; there is no requirement for beneficiary financial institutions to adopt effective risk-based procedures for identifying and handling incoming wire transfers that are not accompanied by complete originator information.

546. The authorities informed the mission that the EC is to issue a Regulation on information on the payer accompanying transfer of funds, which is expected to enter into force on 1 January 2007. The Regulation will be directly applicable in Denmark and therefore the government will need to resolve the potential conflict.

\section{Recommendations and comments}

547. The requirements for wire transfers should be aligned with the international standard (they are currently limited to outgoing payments; not applicable in the case of personal contact and in the case where the sender has an account with the intermediary).

\section{Compliance with FATF Recommendations}

\begin{tabular}{|l|l|l|}
\hline & Rating & Summary of factors underlying rating \\
\hline R.10 & C & \\
\hline
\end{tabular}




\begin{tabular}{|l|l|l|}
\hline SR.VII & PC & $\begin{array}{l}\text { - } \\
\text { The situations in which the requirements apply are narrower than the ones } \\
\text { provided for by the standard (i.e., they do not apply to incoming } \\
\text { payments, where the sender has personal contact with the intermediary or } \\
\text { where the sender has an account with the intermediary). }\end{array}$ \\
$\begin{array}{l}\text { There is no reference to the obligation to obtain and maintain the } \\
\text { originator's account number, though this is mitigated by the required } \\
\text { inclusion of CPR and CVR numbers. }\end{array}$ \\
\hline
\end{tabular}

\section{Unusual and Suspicious Transactions}

\subsection{Monitoring of transactions and relationships $(\mathrm{R} .11 \& 21)$}

\section{Description and analysis}

\section{Recommendation 11}

548. The previous MLA did not provide any obligation for financial institutions to pay special attention to all complex, unusual large transactions, or unusual patterns of transactions, that have no apparent or visible economic or lawful purpose. The new act (section 6.1) now requires all institutions subject to the Act to pay special attention to customers' activities which, by their nature, could be regarded as being particularly likely to be associated with money laundering or terrorist financing, in particular to complex or unusually large transactions and all unusual patterns of transactions in relation to said customer. The explanatory notes indicate few examples, such as the case where an unusually high number of transactions are made for one account, or an unusually large amount is deposited compared to the customer's normal use of the account. The provision appears to be a statement of principle rather than an enforceable obligation, as no sanction is set forth for failure to comply.

549. Section 6.2. sets forth the obligation for the institutions subject to the MLA law to investigate, as far as possible, the purpose of the transactions and to keep record of the findings for at least five years after the completion of the transaction. This provision (whose failure is subject to a fine) will however only enter into force on of January 1, 2007. The power for supervisory authorities to obtain records set forth and kept under this provision is embedded in the general provision empowering the FSA and the DCCA with the right to compel information and to have access during their inspections for the purpose of obtaining information (see sections 32 and 33 of the Act).

\section{Recommendation 21}

550. There is no specific obligation in the MLA for financial institutions to give special attention to business relationships and transactions with persons from or in countries which do not or insufficiently apply the FATF Recommendations.

551. Under the previous Act the FSA was authorized to issue more specific regulations with a view to requiring the institutions subject to the Act to report "systematically" to the FIU all transactions with noncooperative countries in connection with money laundering or financing of terrorism, notwithstanding the absence of suspicion. The provision has been carried over in the new Act. However, no such regulations have been issued pursuant to either act.

552. However, FATF Recommendation 21 requires financial institutions to give special attention to business relationships and transactions with persons, including companies and financial institutions, from countries which do not or insufficiently apply the FATF Recommendations. It places an obligation on FIs to pay close attention to relations and transactions with any country, not just a NCCT, that fails or insufficiently applies the FATF recommendations. 
553. In practice, the FSA has disseminated to the business associations of financial institutions the list of NCCTs with the aim of encouraging financial institutions to pay special attention to transactions or customers from those countries.

554. That said, as noted above, section 6.1 requires all institutions subject to the Act to pay special attention to customers' activities which, by their nature, could be regarded as being particularly likely to be associated with money laundering or terrorist financing, in particular to complex or unusually large transactions and all unusual patterns of transactions in relation to said customer. There is no sanction for failure to comply. Section 6.2. sets forth the obligation for the institutions subject to the MLA law to investigate, as far as possible, the purpose of the transactions and to keep record of the findings for at least five years after the completion of the transaction. This provision (whose failure is subject to a fine) will however only enter into force on of January 1, 2007.

\section{Recommendations and comments}

555. Requirement to investigate the purpose of the complex/unusually large transactions and to keep record of the findings will only enter into force on January 1, 2007.

556. Guidance from supervisory authorities would be helpful as to how implement the provision to monitor customers' activities.

557. A broader requirement to pay special attention to business relationships and transactions with persons from countries which do not or insufficiently apply the FATF recommendations should be introduced.

\section{Compliance with FATF Recommendations}

\begin{tabular}{|c|c|c|}
\hline & Rating & Summary of factors underlying rating \\
\hline R.11 & $\mathrm{NC}$ & $\begin{array}{l}\text { - The requirement to investigate the purpose of the complex/unusually large } \\
\text { transactions and to keep record of the findings is not applicable as it will only } \\
\text { enter into force on of January } 1,2007 \text {. } \\
\text { - The provision obliging to pay special attention to customers' activities and to } \\
\text { complex unusually large transactions does not carry a sanction for failure to } \\
\text { comply and has only recently been introduced such that it cannot be } \\
\text { concluded that the provision is effectively implemented. }\end{array}$ \\
\hline R.21 & $\mathrm{PC}$ & $\begin{array}{l}\text { - No broad requirement to pay special attention to business relationships and } \\
\text { transactions with persons from countries which do not or insufficiently apply } \\
\text { the FATF recommendations. } \\
\text { - } \quad \text { Factors underlying the rating for R.11, also relevant here (re. EC 21.2). }\end{array}$ \\
\hline
\end{tabular}

\section{Description and analysis ${ }^{11}$}

\section{R.13 and SR IV}

\section{General description}

558. The Act on Measures to Prevent Money Laundering and the Financing of Terrorism of $2006^{12}$ (hereafter, the MLA) contains express provisions in sections 7(1), (2), (3) (4), section 9 and section 10 that impose the obligation of reporting any transaction suspected of being related to either money laundering or the financing of terrorism. The basic obligation is set forward in section 7(1) as follows:

"If there is a suspicion that a customer's transaction or enquiry, is or has been associated with money laundering or financing of terrorism, the undertakings and persons covered by this Act shall investigate the transaction or 
enquiry in more detail. If the suspicion relates to offences punishable by imprisonment of more than 1 year and this suspicion cannot be disproved, the Public prosecutor for Serious Crime shall be informed immediately". ${ }^{13}$

559. Section 7 (2) sets up an optional reporting mechanism for lawyers through their Bar and Law Society (See Section 4.2, below). Section 7 (3) and (4) set forth the rules for suspending transactions. Section 9 imposes the same obligation on the supervisory authorities, and Section 10 gives the FSA regulation-making authority to enhance reporting concerning transactions with "non-cooperative" countries. Failure to report or to suspend transactions on the part of the reporting entities is sanctionable with a criminal fine, or with imprisonment up to six months in aggravated circumstance.

560. Money laundering is defined directly for this act in Section 4. Terrorist financing is defined by reference to section 114a of the Criminal Code.

561. The provisions for suspending transactions differ depending on whether the suspicion regards moneylaundering (7 (3)) or terrorist financing (7 (4)). In 7 (3), the transaction shall be suspended until the FIU is notified, except in cases where carrying out the transaction cannot be avoided or if this is deemed to be potential harmful to the investigation, in which case reporting must immediately follow. In 7 (4), transactions can only be carried out with permission of the FIU, who must decide within one banking day after receiving notification, whether the funds should be seized.

562. These provisions elaborate and consolidate the provisions of the 1993 act ((Sections 10a and 10b). The major change that was introduced in the new legislation was the exemption for reporting suspicions relating to predicate offences that were punishable by less than one year's imprisonment. The specific stipulation that the undertaking should conduct a preliminary investigation before reporting to the FIU appears in both the 1992 and the 2006 laws.

563. In addition to the specific authority granted in Section 10, the FSA also has regulation-making authority regarding reporting entities internal rules on reporting. It has not chosen to exercise either of these authorities to date. Therefore, the provisions of the MLA itself are the only law, regulation, or enforceable means bringing these obligations into force.

564. The Banker's Association has, with the assistance of the authorities, issued guidelines to its members, which would assist them in the implementation of the new MLA. While those guidelines cannot be considered enforceable, they certainly represent a valuable contribution to the general effectiveness of the AML/CFT regime in Denmark. They list criteria for determining suspicion, including the legitimacy of purpose of the transaction, is the transaction generally unusual, nature of the transaction, size, recipient country whether known as a tax or drug haven, dissimilarity with other transactions, origin of the money, general customer's situation and affairs. They also outline the different steps that must be adopted by the employee. They instruct the bank to set up an internal reporting system or give the board of management overall responsibility for investigating suspicions and reporting to the police. They describe how to carry out an internal investigation at the bank which should only cover the circumstances relating to the transactions carried out by the bank. For example, the person to whom the suspicion relates must never be contacted except as regards normal supplementary information. Notification to the Police must be sent by fax and not by email to the Public Prosecutor Office. Specific cases that give rise to doubts as to whether the situation may be informally discussed over the telephone with the Secretariat.

565. The overall statistics concerning STR reporting from the financial sectors is as follows:

\begin{tabular}{|l|c|c|c|c|c|c|}
\hline & $\mathbf{2 0 0 0}$ & $\mathbf{2 0 0 1}$ & $\mathbf{2 0 0 2}$ & $\mathbf{2 0 0 3}$ & $\mathbf{2 0 0 4}$ & $\mathbf{2 0 0 5 ^ { * }}$ \\
\hline Banks & 133 & 205 & 216 & 176 & 200 & 194 \\
\hline Mortgage credit institutes & 1 & 0 & 1 & 1 & 2 & 2 \\
\hline Insurers and investment managers** & 0 & 0 & 0 & 0 & 0 & 1 \\
\hline
\end{tabular}




\begin{tabular}{|l|c|c|c|c|c|c|}
\hline Foreign exchange bureaus & 114 & 114 & 115 & 77 & 109 & 121 \\
\hline Money remittance operators ** & & & & 17 & 42 & 95 \\
\hline Postal services** & & & & 1 & 0 & 0 \\
\hline Money transport services** & & & & 0 & 0 & 0 \\
\hline Other*** & & & 6 & 0 & 1 & 0 \\
\hline Total & $\mathbf{2 4 8}$ & $\mathbf{3 1 9}$ & $\mathbf{3 3 8}$ & $\mathbf{2 7 2}$ & $\mathbf{3 5 4}$ & $\mathbf{4 1 3}$ \\
\hline
\end{tabular}

* Up till 12/12 2005

** From June 2002

*** From June 2002 (an overall figure in 2002 for new businesses subject to the duty of reporting).

566. STRs concerning the financing of terrorism have been a relatively small percentage of this total, amounting to 34 in 2004 and 40 in 2005 . Of these, the FIU reported that most involved queries regarding false "hits" on the name lists maintained by the EU. In addition to these 40 STRs, financial institutions reported making many other "false hit" enquiries that the FIU did not consider to have the status of an STR.

\section{Analysis}

567. The MLA sets up a mandatory reporting obligation for financial institutions. The obligation is based on a subjective test of suspicion, as permitted by the FATF Recommendations.

568. However, the MLA introduces an unnecessary and undesirable misalignment between the criminalization standard and the reporting obligation by allowing financial institutions not to report suspicions relating to predicate offences that carry a sentence of less than one year's imprisonment. This misalignment is technically allowable under the FATF standard ${ }^{14}$, but is a deviation from best practice that could have a adverse impact on the effectiveness of the reporting obligation.

569. The law appears to expect that financial institutions both know the predicate crime and be aware of its legal sanction. However, the Explanatory note specifically states that the law did not intend for employees to assess the underlying crime or possess legal expertise. This confusion between the text of the law and the explanatory note effectively leaves reporting institutions with no clear official guidance on how they are supposed to implement this "one-year rule."

570. Most reporting institutions interviewed were not comfortable with the "one-year rule" as drafted (even if the provision may have been introduced in response to their original concerns about overly rigid reporting requirements.) Most have chosen to take a conservative approach to this legal tangle and just report all suspicions anyway, for simplicity and to avoid any possible liability. However, any reporting institution that chose - for whatever reason - to circumvent its reporting obligation would appear to have a fairly easy defense in the law.

571. It should be noted that, under the sanctions in the Danish Criminal Code, the "one-year rule," if applied, would exempt grossly negligent receiving of stolen goods (Section 303), as well as various forms of criminal trespass, tampering with mail/communications, or eavesdropping (Section 263). There is also a tension between the explicit requirement in the standard that all transactions be reported "regardless of the amount of the transaction" and the exemption for reporting transactions associated with crimes punishable by less than one year's imprisonment.

572. Overall, Danish reporting entities have filed significantly fewer STRs than those in most jurisdictions that have been assessed using the 2004 methodology. . The following chart presents STRs filed during the year immediately before the assessment (usually 2004, with a few 2003). It excludes some countries which had no STRs because their AML/CFT regimes had not yet been established 
STRs

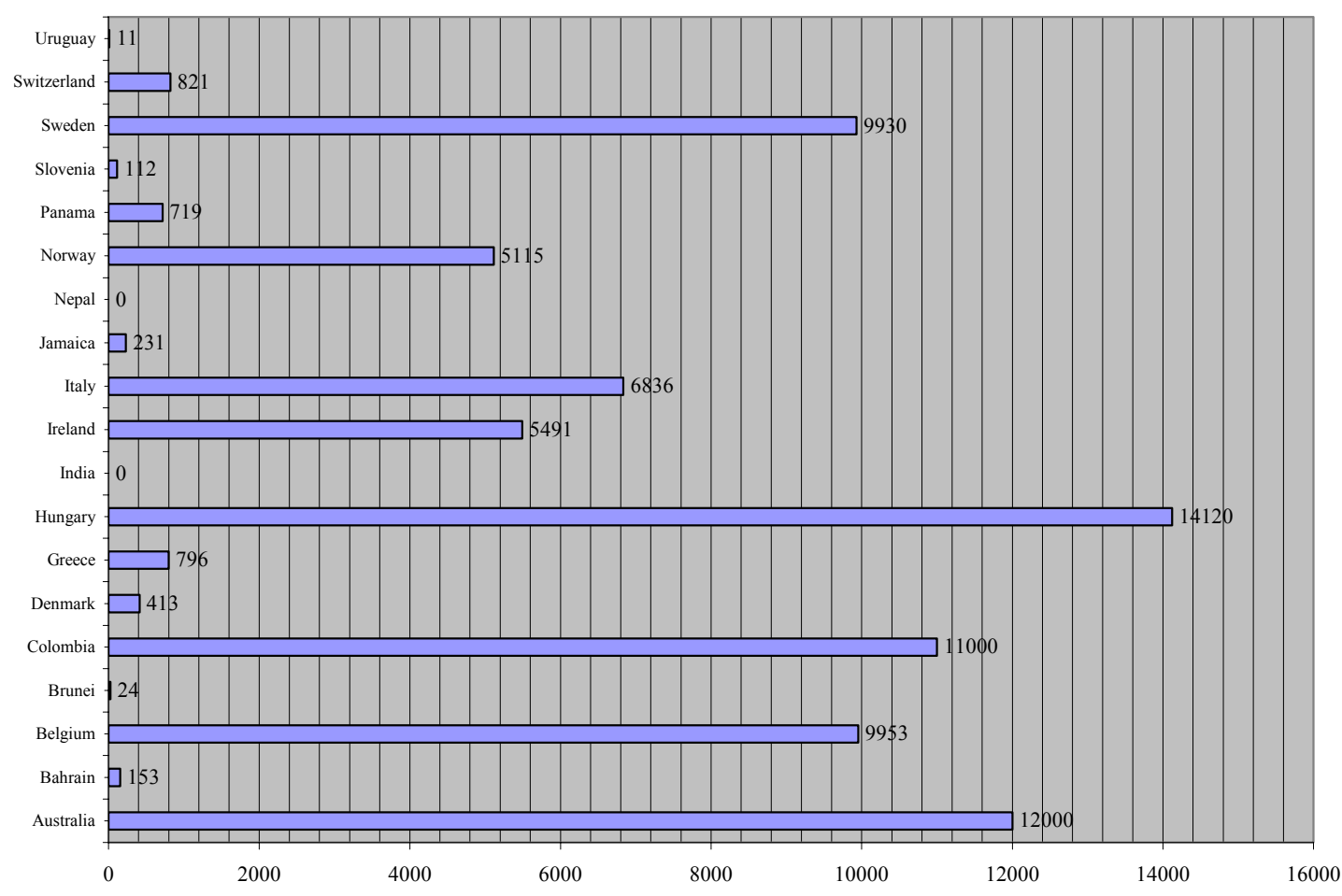

573. Absolute numbers of all STRs do not provide a good basis for comparing Denmark's effectivness, given the differences between the jurisdictions in the sample. One step towards more meaningful analysis would involve looking only at the data for "commercial" banks, as those institutions tend to be defined similarly in many jurisdictions and have tended to have more experince with AML/CFT obligations. However, not all DARs contain breakdowns of STRs by type of reporting entity, so the following graph compares Denmarkwith a smaller group of coutnries. 


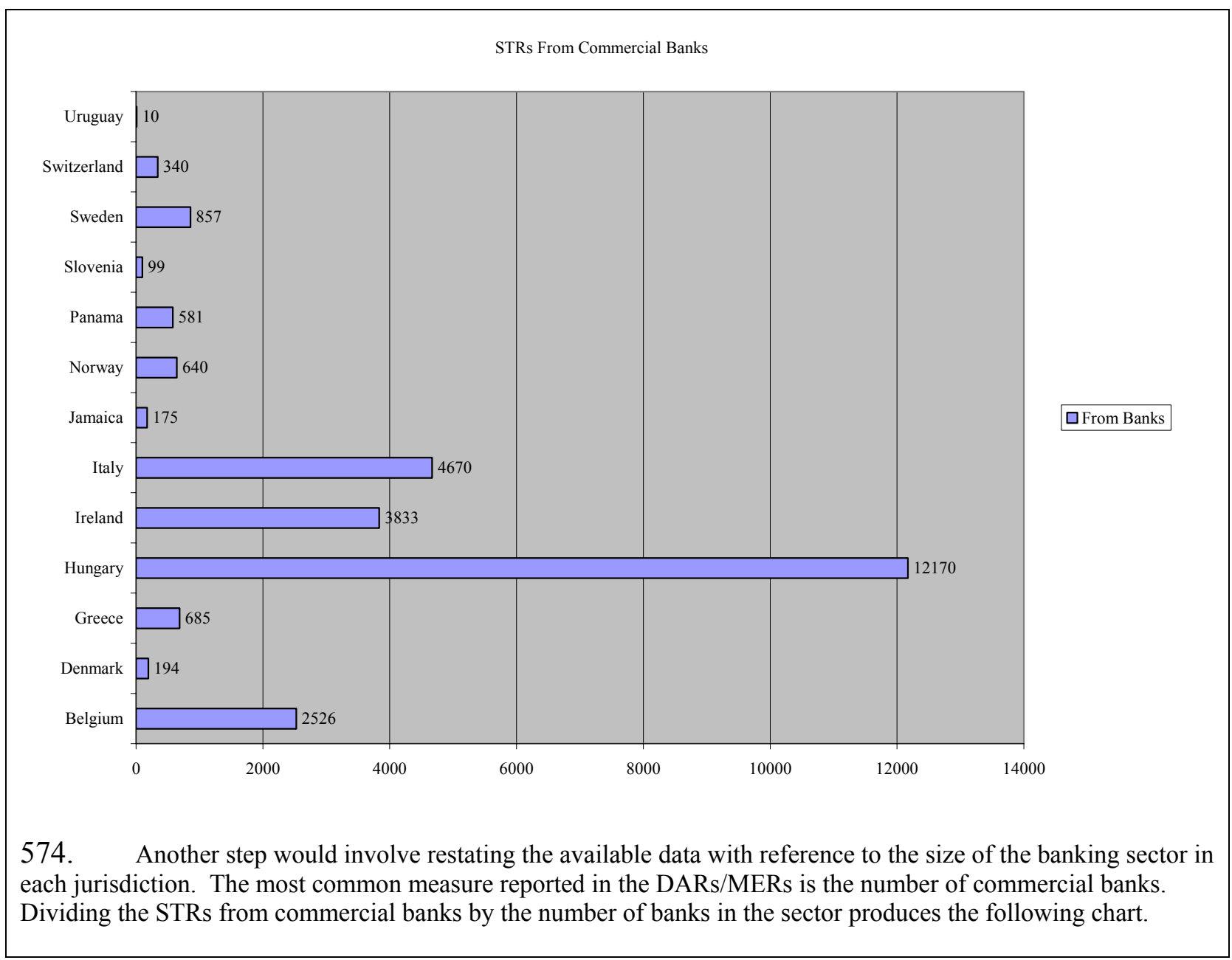




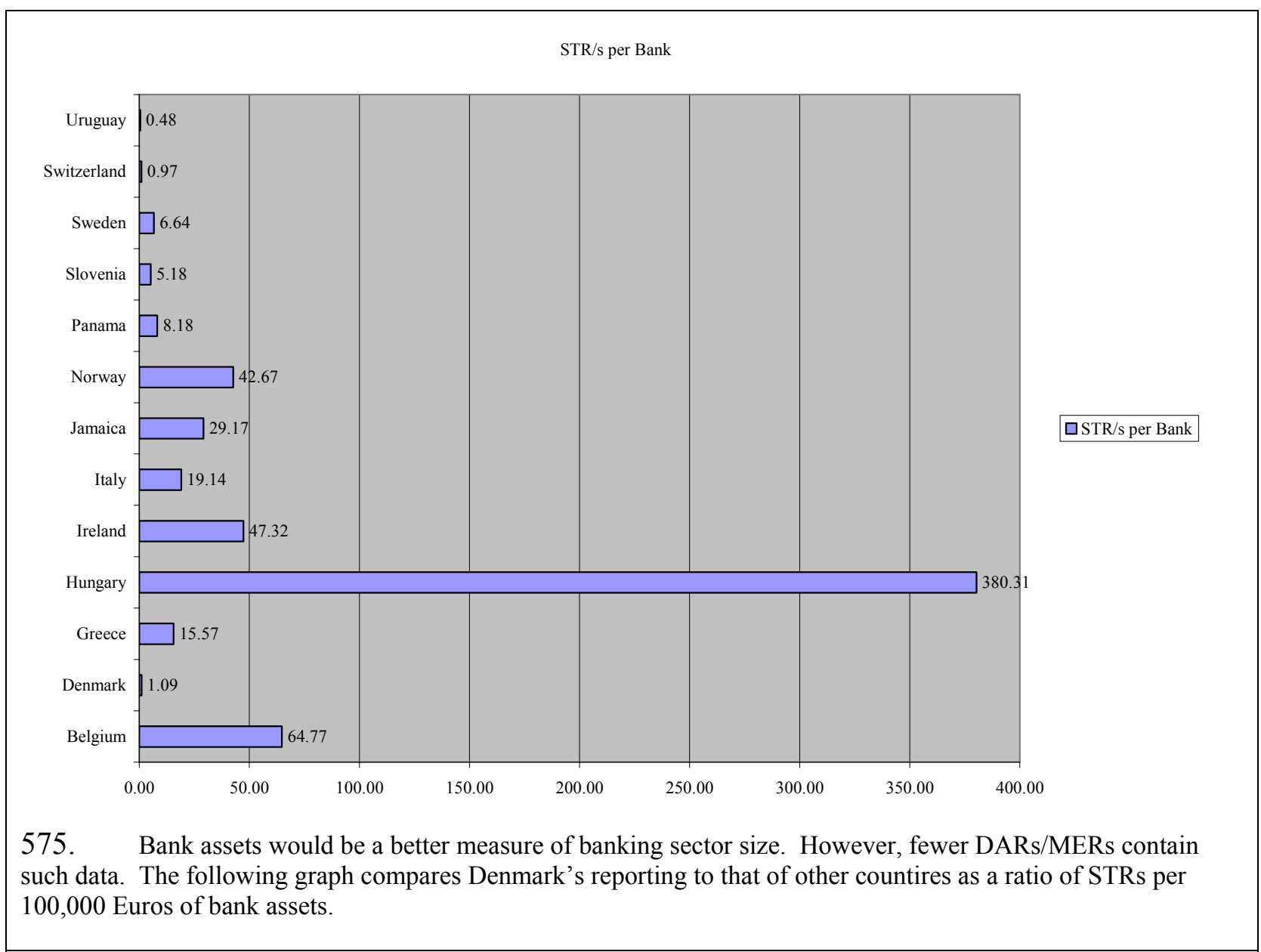




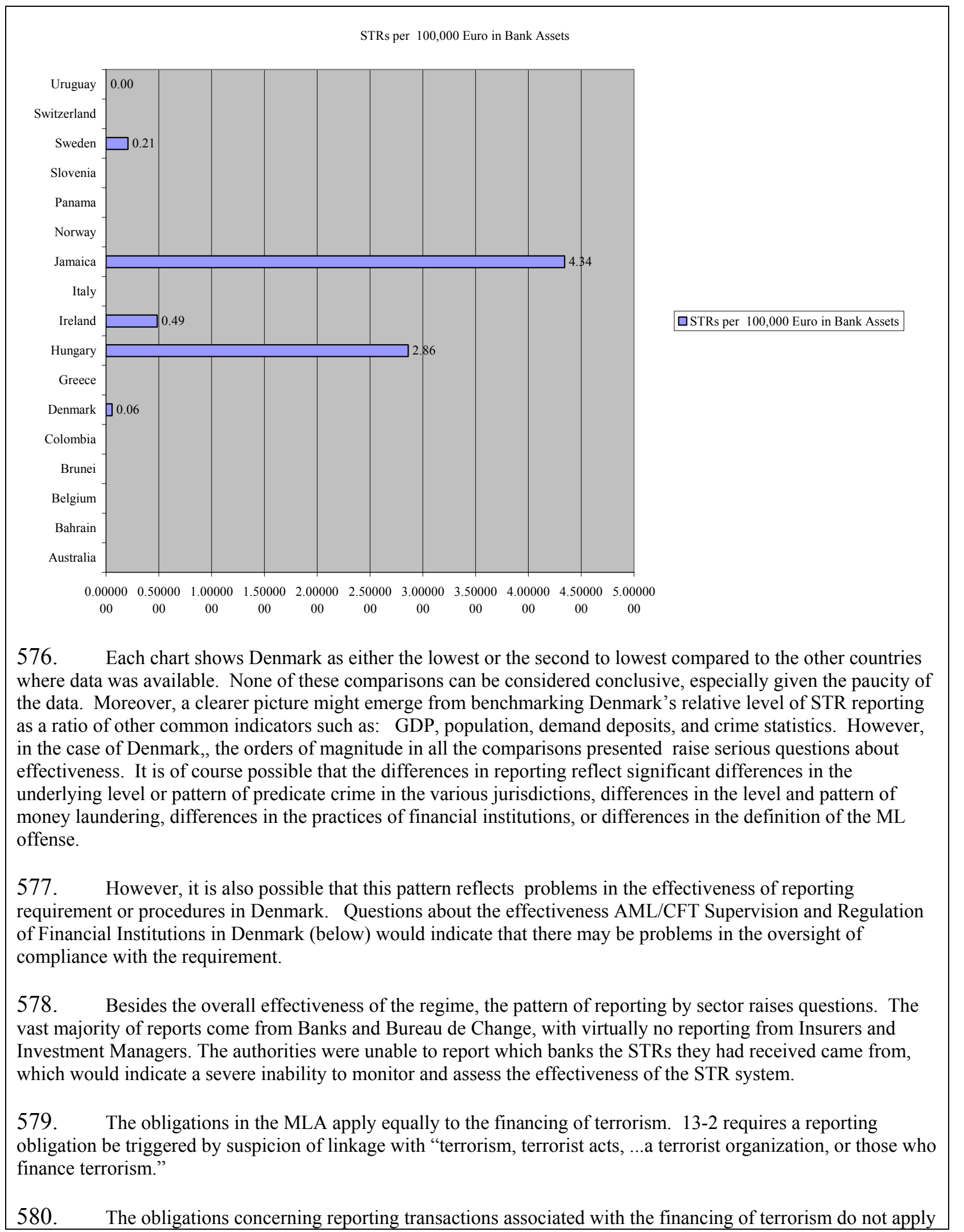


in Greenland and the Faroe Islands.

Attempted transactions

581. The requirement for reporting attempted transactions is established indirectly, via two mechanisms:

- 7-1 refers to a customer's "transaction or enquiry."

- the definition of "money laundering" in section 4 of the Act explicitly includes "attempting...such actions," which is recalled in the Explanatory Note to Sections 7 as explicitly intended to reinforce the reporting requirement for attempted transactions.

While either of these mechanisms by themselves might be insufficient, the two together, with the Explanatory Note would appear to fully meet the first part of the criteria.

582. There is no direct requirement for reporting attempted transaction in force in Greenland or the Faroe Islands. The 1993 law, like the 2006 law, defines money laundering to include the attempt to launder money, but this would only mean that reporting entities are required to report transactions that are associated with an attempt to launder money, but would not be required to report (as the standard states) an attempt to perform a transaction that is associated with money laundering (i.e. a customer who cancels a transaction when queried about the source of funds).

583. There is no exemption for tax-related matters in the MLA, so this criterion is fully met.

\section{SR IV}

584. See paragraphs 580-581, above.

\section{R14}

585. Section 26 of the MLA establishes a protection from liability and exemption from confidentiality duties for all reporting entities, their employees and managers for notifications and information given in good faith in accordance with the provisions on suspicious activity reporting. In addition, they are further protected from liability concerning suspension of transactions under the terrorist financing rules (Section 7 (4)). However, there is no such protection concerning suspension of transactions when those are associated with money laundering (Section 7 (3)). These provisions, however, are not required by the FATF standard.

586. The prohibition against disclosing the fact that an STR has been filed is established by Section 27 of the MLA. The prohibition covers not only reporting to the FIU, as required by Recommendation 14, but also that filing an STR is being considered and/or that an investigation has been or will be instigated. Exceptions are permitted for communication with the competent authorities, and for communications within undertakings belonging to the same financial group ${ }^{15}$, between lawyers and accountants who work within the same legal unit or network, between unrelated financial institutions about shared customers, as well as between financial institutions and lawyers about shared customers..

\section{Recommendation 19}

587. In 1993, the authorities asserted in a FATF self-assessment that they had considered establishing a cash transaction reporting system and had decided not to. In 1996, their Mutual Evaluation Questionnaire indicated that they this position had not changed. No more contemporary consideration could be demonstrated, although the authorities indicated that the matter had been discussed "on an on-going basis.." 
588. There have been no guidelines established for Financial Institutions by the competent authorities. The Banker's Association guidelines, while comprehensive and helpful, do not meet this formal requirement.

589. All financial institutions interviewed reported that they have never received feedback on the STRs they had filed with the FIU.

\section{Recommendations and comments}

590. Explore the possibility of removing the misalignment between the criminalization standard and the reporting requirement.

591. Take measures to ensure that employees in reporting entities maintain high levels of vigilance, despite the restricted nature of the reporting requirement.

592. Assess effectiveness of the suspicious activity reporting regime to check for potential under-reporting.

593. Adopt measures that bring the reporting regime in Greenland and the Faroe Islands up to international standards, especially in the area of terrorist financing.

594. Enhance outreach to insurers and investment agents.

595. Monitor and report on which banks are sending STRs to identify possible targets for outreach.

596. Consider adopting measures to protect those who suspend transactions associated with money laundering from liability.

\section{Compliance with FATF Recommendations}

\begin{tabular}{|c|c|c|}
\hline & Rating & Summary of factors relevant to section 3.7 underlying overall rating \\
\hline R.13 & $\mathrm{PC}$ & $\begin{array}{l}\text { - Low level of reporting raises effectiveness questions. } \\
\text { - } \quad \text { Negligible reporting from insurers and investment managers. } \\
\text { - } \quad \text { Insufficient monitoring of financial institution participation in the system. } \\
\text { - Greenland/Faroe Islands reporting requirements do not meet standards for TF } \\
\text { and attempted transactions. }\end{array}$ \\
\hline R.14 & $\mathrm{C}$ & $\bullet$ \\
\hline R.19 & LC & $\begin{array}{l}\text { - No tangible evidence of recent proper considertation of the feasibility and } \\
\text { utility of implementing a system whereby financial institutions report all } \\
\text { transactions in currency above a fixed threshold to a centralized agency with } \\
\text { a computerized database. }\end{array}$ \\
\hline R.25 & $\mathrm{NC}$ & $\begin{array}{l}\text { - } \quad \text { NC for this section as well) } \\
\text { - } \quad \text { No guidelines issued. } \\
\text { - } \quad \text { More feedback to reporting entities needed. }\end{array}$ \\
\hline SR.IV & LC & - $\quad$ No reporting requirement in Greenland/Faroe Islands \\
\hline
\end{tabular}

\section{Internal Controls and Other Measures}




\subsection{Internal controls, compliance, audit and foreign branches (R.15 \& 22)}

\section{Description and analysis}

597. Under the previous Act the covered institutions - with the exception of Post offices, bureaux de change; money remitters and money transportation undertakings - were obliged to draw up written internal rules on adequate control and communication procedures and training instruction programs for their employees. According to the Act these internal rules should at least cover customer identification procedures, record keeping and monitoring and reporting of suspicious transactions to the FIU.

598. The obligation is now set forth - for all institutions subject to the Act - in section 25 and obliges covered institutions to " prepare adequate written internal rules about customer due diligence, reporting, recordkeeping, internal control, risk assessment, risk management, management controls and communication as well as training and instruction programs for their employees in order to forestall and prevent money laundering and terrorist financing." The explanatory notes clarify that the provision imposes on the undertakings the preparation of internal rules on adequate control and communication procedures, including regulations to ensure that the customer's identity is ascertained, how the undertakings are to investigate suspicious transactions and a procedure for notification of the police. The internal rules may also contain a description of customer types and/or products regarded as being low-risk or high-risk and the reason for this. The requirement that the guidelines are to be in writing is regarded as having been met if they are stored digitally. The explanatory notes clarify also the training obligation by stating that undertakings are required to prepare training program that ensure that staff, including members of management, receive the necessary instructions for the execution of adequate control and notification measures.

599. The requirement that the written internal rules must be "adequate" will be implemented on a basis of an assessment of the undertaking dealing with low-risk customers or offering low-risk products and therefore requirements can be assessed from a risk-based point of view. The requirements for written internal rules will also depend on the size of the undertaking.

600. The previous act did not require the financial institutions to designate a compliance officer at management level. In practice, the FSA often sees that the written internal rules of a bank appoint a person at the management level who is responsible for dealing with suspicious transactions reporting to the FIU or other issues related to the prevention of money laundering and terrorist financing. In the larger institutions this would often be the head of the legal division in a bank. For smaller institutions it would often be the managing director. Under section 25(2) of the new act the following institutions are required to appoint a compliance officer at management level:

- Banks.

- Mortgage-credit institutions.

- Investment companies.

- Investment management companies.

- $\quad$ Life assurance companies and lateral pension funds (nationwide occupational pension funds).

- $\quad$ Savings undertakings.

- $\quad$ Electronic money institutions.

- Insurance brokers, when they act in respect of life assurance or other investment-related insurance activities.

- $\quad$ Foreign undertakings' branches in Denmark, carrying out activities under nos. 1-8.

- Investment associations and special-purpose associations, collective investment schemes, restricted associations, innovation associations and hedge associations.

601. While there are no requirements concerning the access of the compliance officer or other appropriate 
staff to customer records and relevant information it is implicit from the language of the MLA (section 25.2 calls for the appointment of the compliance officer to ensure compliance with the obligations set forth in the MLA) that such access should be made available. There are no requirements for screening procedures for hiring employees or to maintain an independent audit function to test compliance. However, according to Section 199 of the FBA, financial undertakings shall have at least one external auditor.

602. Section 25.1 sets forth, among others, the obligation for financial institutions to have written rules on internal audit. According to Section 9(1) of the Executive Order on Auditing Financial Undertakings the board of directors can decide to establish an internal audit function. This internal audit function can undertake some of the duties of the external auditors mentioned in Section 199 of the FBA. The auditors are independent and only report to the board of directors.

603. According to the Section 6(1)d of the Executive Order, the audit book comments relating to the annual report shall state whether the external auditors are aware of conditions which are in conflict with the requirements in legislation regarding financial undertakings and associations. There is no specific obligation for the auditors to especially review the AML/CFT-area. Nor is there a specific requirement to conduct sample testing of proof of identity.

604. Financial institutions that were interviewed during the course of the mission had, in general, developed written internal policies and procedures to varying degrees of comprehensiveness. However. the scope and intensity of initial and ongoing employee training programs are insufficient and should be stepped up.

\section{Recommendation 22}

605. There were no requirements in the previous Act regarding foreign branches or subsidiaries. Under the new law section 24 imposes certain requirements in the case of the following institutions:

- Banks.

- Mortgage-credit institutions.

- Investment companies.

- Investment management companies.

- Life assurance companies and lateral pension funds (nationwide occupational pension funds).

- Savings undertakings.

- Electronic money institutions.

- Investment associations and special-purpose associations, collective investment schemes, restricted associations, innovation associations and hedge associations.

- Undertakings and persons that commercially carry out activities involving currency exchange or transfer of money and other assets.

- Other undertakings and persons that commercially carry out one or more of the activities mentioned in annex 1 of the MLA (i.e. leasing- and factoring institutions etc).

606. According to section 24 these institutions must ensure that their branches and subsidiary undertakings which are established in countries outside the EU and with which the Community has not entered into an agreement for the financial area, carry out AML requirements (customer due diligence measures, record keeping, reporting obligations etc.) to standards which are corresponding to the requirement of the Third Money Laundering Directive, to the extent that the legislation of said country allows this. According to the explanatory notes the provision particularly relates to the establishment of branches and subsidiary undertakings in countries which have not adequately implemented the recommendations if the relevant country where the branch/subsidiary is located does not allow the use of measures corresponding to the requirements of the Third Money Laundering Directive the covered institutions are required to inform the authority supervising the undertaking's compliance with the Act. This notification is to be submitted to the Commission in accordance with Article 31 (2) of the Directive. In such circumstance the Directive requires the financial institutions to take 
additional measures to effectively handle the risk of $\mathrm{Ml}$ or $\mathrm{TF}$.

607. Subsection (3) of the provision requires financial institutions that their branches and subsidiary undertakings established in countries outside the European Union with which the Community has not entered into an agreement for the financial area have written internal rules regarding customer due diligence and recordkeeping corresponding to the requirements set forth in section 24(1) of the Act, to the extent that the legislation of said country allows this.

\section{Recommendations and comments}

608. Guidance should be provided to the financial institutions to ensure that the compliance officer or other appropriate staff has access to customer records and relevant information.

609. The scope and intensity of initial and ongoing employee training programs should be stepped up.

610. Requirements should be introduced to ensure that reporting entities have adequate screening procedures for hiring employees

\begin{tabular}{|c|c|c|}
\hline \multicolumn{3}{|c|}{ Compliance with FATF Recommendations } \\
\hline & Rating & Summary of factors underlying rating \\
\hline R.15 & LC & $\begin{array}{l}\text { - There are no requirements for screening procedures for hiring employees } \\
\text { or to maintain an independent audit function to test compliance. } \\
\text { - The scope and intensity of initial and ongoing employee training programs } \\
\text { appear to be insufficient. }\end{array}$ \\
\hline $\mathbf{R . 2 2}$ & LC & $\begin{array}{l}\text { The requirement is newly established and has not yet been effectively } \\
\text { implemented. }\end{array}$ \\
\hline
\end{tabular}

\subsection{Shell banks (R.18)}

\section{Description and analysis}

611. Bank licensing requirements preclude the establishment of shell banks in Denmark. Prior to engaging in banking activities in Denmark an applicant must obtain a license from the FSA (Sections 7 and 14 of the FBA), which is the sole authority for granting banking licenses. Before the FSA grants a banking license, it must be ensured that the undertaking in question meets certain criteria. According to Section 14(1) 1 and 2 of the FBA, a set criteria apply (e.g., the undertaking must have a share capital of no less than EUR 8 million (Section 7(1) of the FBA) and is organized as a limited company (Section 12)). Pursuant to Section 14(1) no. 3, a license is only granted when the owners of qualifying interests will not oppose appropriate and reasonable management of the bank or mortgage-credit institution.

612. According to Section 14(1) no.7, the FSA only grants a license when the applicant has its headquarters and registered office in Denmark. Furthermore, the FSA will withdraw the license to operate as a bank if the bank does not meet the requirements of Section 14 of the FBA. Moreover, pursuant to section 224(1) no.3the Financial Business Act (FBA), the FSA can withdraw a license to operate as a bank, mortgage-credit institution, investment company, investment management company and insurance company if the undertaking fails to commence operation as a financial undertaking no later than 12 months after having been granted a license by the FSA.

613. Pursuant to the Danish corporate structure, the management of a bank consists of a board of directors and a board of management, cf. sections 49, 51 and 54 of the Companies Act. Section 14(1) no. 2 in conjunction with section 64 of the FBA and a guideline provide evaluation criteria regarding the fitness and propriety (i.e., 
education, experience and professional qualification, trustworthiness) of the proposed board of directors and board of managers. Directors and managers of the bank must be competent and fit for the specific business of the new bank, i.e., their personal integrity and professional skill as well as their experience must meet the demands of their new task.

614. The above requirements ensure that a licensed bank has meaningful mind and management within Denmark and therefore preclude the establishment of shell banks in Denmark.

615. According to Section 19(5) of MLA, banks, mortgage-credit institutions and electronic money institutions may not enter into or continue a correspondent banking relationship with a shell bank. They are also required to take reasonable measures to avoid a connection with a credit institution which is known to permit shell banks to use its accounts. However, the measures will only take effect on January 1, 2007.

\section{Recommendations and comments}

616. The provisions that address the deficiencies will come into force on January 1, 2007.

\begin{tabular}{|l|l|l|}
\hline \multicolumn{2}{|c|}{ Compliance with FATF Recommendations } \\
\hline R.18 & Rating & Summary of factors underlying rating \\
& PC & $\begin{array}{l}\text { Measures not yet in force to prohibit the continuance or entry into } \\
\text { correspondent relationship with shell banks and to avoid a connection } \\
\text { with credit institutions that permit their accounts to be used by shell } \\
\text { banks. }\end{array}$ \\
\hline
\end{tabular}

\section{$\underline{\text { Regulation, Supervision, Guidance, Monitoring and Sanctions }}$}

\subsection{The supervisory and oversight system-competent authorities and SROs: Role, functions, duties and powers (including sanctions) (R.23, 30, 29, 17, 32 \& 25)}

\section{Description and analysis}

\section{$\underline{\text { Authorities/SROs roles and duties \& Structure and Resources (R23, 30) }}$}

\section{Recommendation 23 (Criterion 23.1)}

617. The FSA is responsible for regulating and supervising all financial institutions, except undertakings and persons that commercially carry out activities involving currency exchange or transfer of money and other assets (money remitters and exchange bureaus) which are regulated and supervised by the DCCA.

\section{FSA}

618. Sections 344, 346, 347 and 348 (part 21) of the FBA authorize the FSA to supervise the following entities:

1. Financial undertakings defined as:
a) Banks (credit institutions)
b) Mortgage-credit institutions
c) Investment companies (securities dealers and brokers)
d) Investment management companies
e) Insurance companies

2. Electronic money institutions and savings institutions 
619. The FSA's powers to supervise insurance brokers are provided in the Insurance Mediation Act, part 10. As for Investment associations and special-purpose associations, collective investment schemes, restricted associations, innovation associations and hedge associations the powers of the FSA are stated in Investment Associations Act, part 18. All the above must be licensed by the FSA.

620. While the FBA does not specifically authorize the FSA to supervise for compliance with the MLA, in practice the FSA has supervised most of the above entities for compliance in this regard ${ }^{16}$. Section 34 of the new MLA however clarifies the FSA's powers to supervise, as of March 1, 2006, the above entities for compliance with the AML/CFT requirements, in addition to other entities that were not previously supervised for AML/CFT compliance, i.e., credit card, leasing, factoring and other lending companies (i.e., finance/consumer credit companies). In particular, the MLA authorizes the FSA to ensure AML/CFT compliance for the following:

1) Banks.

2) Mortgage-credit institutions.

3) Investment companies.

4) Investment management companies.

5) Life insurance companies and lateral pension funds (nationwide occupational pension funds).

6) Savings undertakings.

7) Electronic money institutions.

8) Insurance brokers, when they act in respect of life assurance or other investment-related insurance activities.

9) Foreign undertakings' branches in Denmark, carry out activities under nos. 1-8.

10) Investment associations and special-purpose associations, collective investment schemes, restricted associations, innovation associations and hedge associations.

11) Other undertakings and persons that commercially carry out one or more of the following activities:

a) Acceptance of deposits and other repayable funds.

b)Lending, including

i) consumer credit,

ii)mortgage-credit loans,

iii) factoring and discounting,

iv) financing of commercial transactions (including forfeiting).

c) Financial leasing.

d)Payment services (money transmission services).

e) Issue and administration of means of payment (e.g. credit cards, travelers' cheques, and bankers' drafts).

f) Guarantees and collateralization.

g) Trading for own account or for account of customers in:

i) money market instruments (cheques, bills, certificates of deposit, etc.)

ii)the foreign exchange market

iii) financial futures and options

iv) currency and interest rate instruments

v) securities.

h)Participation in issuing securities and provision of related services.

i) Advice to undertakings on capital structure, industrial strategy and related questions and advice, and services relating to mergers and the acquisition of undertakings.

j) Money broking.

k)Portfolio management and advice.

1) Safekeeping and administration of securities.

m) Safe custody services.

621. The institutional coverage is comprehensive. However, credit card companies, leasing and factoring companies not otherwise affiliated with banks and other lending companies (i.e., finance/consumer credit companies) have only been subject to AML/CFT supervision since March 1, 2006 and while such persons and 
undertakings are now required to register with the FSA, there are no fit or proper tests for owners, directors or managers associated with registration.

622. In addition, while life insurance brokers have been subject to monitoring by the FSA further to the Insurance Mediation Act, the FSA did not have the authority to conduct on-site inspections. As of March 1, 2006, the MLA extends the powers of the FSA to supervise life insurance brokers for AML/CFT, including for on-site inspections (without a court order). Life insurance agents and sub-agents are not covered by the MLA, although many banks are currently registered with the Danish Insurance Association as insurance agents and, as such, the activity would be covered to this extent by the MLA.

623. While in practice the FSA has supervised foreign undertakings' branches in Denmark that carry out the activities of 1) to 8) above, Section 34 of the MLA now authorizes the FSA to do so as of March 1, 2006.

624. The mission was informed by two of the larger financial institutions that they had not yet had an onsite inspection for AML/CFT. The authorities confirmed that as part of the regular on-site inspection activities at the largest banks, the internal guidelines concerning AML/CFT are reviewed. This had been carried out in 2 of the 5 largest banks. For the remaining large banks the procedure had been to review the issue on a risk basis during ordinary inspections of their foreign operations and within their private banking business area, where knowledge of the customers can be limited, or if the bank is a subsidiary of a foreign bank within the EU the onsite inspections are coordinated with the home supervisory authority on a consolidated basis, including inspections regarding AML/CFT. If an inspection of a specific issue has been carried out for the consolidated banking group the FSA does not necessarily perform its own on-site inspection of the same issue. Late April 2006, the FSA informed the assessment team that of the 3 large banks that had not had an AML/CFT on-site inspection at the time of the mission, two had since been inspected and there were plans to inspect the remaining bank shortly thereafter.

625. With respect to small- and medium-sized banks, AML/CFT inspections are as a general rule part of a normal inspection. Since 1997 the FSA has gone through the banks internal procedures and since the beginning of 2004 it has conducted spot tests on proof of identity. On-site inspections are conducted at least every four years with exception of institutions with a balance below 100 million. kr which are inspected at least every seven years.

626. With respect to mortgage banks, the FSA has asked all of them to submit their internal guidelines to the FSA in order to make an evaluation of these guidelines. FSA has not issued any comments on the submitted guidelines. However, the FSA has not conducted any specific AML/CFT inspections. The authorities note that almost all the customers in a mortgage bank originate from a bank.

627. On site inspections of life insurance companies and pension funds have taken place on a regular basis since 2000. Life insurance companies and pension funds are inspected with a frequency of up to seven years. As part of these regular on-site inspections the internal guidelines and procedures, and potential AML/CFT transactions, are reviewed.

628. AML/CFT inspections are part of a normal inspection of investment companies. Since 1997/98, the FSA has been reviewing their internal procedures and conducting spot tests on proof of identity.

629. The FSA's inspection manual for AML/CFT is not comprehensive (e.g., no sample-testing of transactions, little guidance for assessing the adequacy of measures). The FSA is now working on updating the inspection manual to take account of the new provisions of the MLA.

630. Overall the FSA's inspection policies and procedures, and practice (see also section on R. 32) for $\mathrm{AML} / \mathrm{CFT}$ are not sufficient as regards scope and frequency.

631. The FSA has authority to issue secondary legislation for certain provisions under the law. Although 
not provided for specifically in the FBA or the MLA, it can issue non-binding guidance. Regulation-making authority is provided for in the following areas:

- Exempting the above persons or undertakings and those that commercially carry out activities involving currency exchange or transfer of money and other assets from the application of the law further to a decision of the European Commission pursuant to the $3{ }^{\text {rd }}$ Money laundering Directive;

- Imposing additional obligations on reporting entities to report transactions with NCCTs to the FIU, regardless of suspicion of ML/TF;

- Exempting certain products or transactions from verification of identity requirements further to a decision of the European Commission ;

- Imposing more detailed requirements on persons or undertakings covered by the MLA with respect to having adequate written internal rules on CDD, reporting, record-keeping, internal controls, risk assessment, risk management, management controls and communication, as well as on training and education, programs for their employees; and

- Authorizing or prohibiting further to a decision of the European Commission, the group-wide disclosure of STR information by persons or undertakings in Denmark to persons or undertakings within the group that are located in countries outside the EU with which the Community has not entered into an agreement for the financial area.

632. The FSA does not, however, have regulation-making authority to set out more detailed requirements for preventive measures. While it can issue more detailed requirements for having written internal rules and sanction the absence of such rules, there is no particular sanction for the failure to implement such rules This is all the more an issue given that the FSA cannot issue legally enforceable guidelines. No regulations have been promulgated under the current Act or its predecessor (which only allowed the Minister for Economic and Business Affairs to lay down specific rules on internal control procedures, internal guidelines, and training of staff for insurance brokers and certain DNFBPs).

633. More detailed requirements could nonetheless be set out in non-binding guidance. While the FSA has not issued any guidance on AML/CFT, these are now being developed.

\section{DCCA}

634. Section 1(1) no.4 of the previous MLA required, as of January 1, 2004, the registration with the DCCA of undertakings involved with the transfer of money or other assets not otherwise supervised by the FSA (i.e., money remitters), although it did not provide for a fit and proper for owners, directors or managers. The law also authorized the DCCA to ensure compliance of money remitters with the MLA. While the DCCA was not authorized to conduct on-site inspections to ensure compliance with AML/CFT requirements, Section 12 required money remitters to provide the DCCA with information necessary for its supervision of compliance, although there was no fine for failing to do so. The DCCA has, in any event, exercised its supervisory role, having conducted a number of on-site inspections of money remitter agents and sub-agents since early 2005.

635. Section 32 of the new MLA provides that, as of March 1, 2006, the DCCA is the supervisory authority for undertakings and persons that commercially carry out activities involving currency exchange or transfer of money and other assets (money remitters and currency exchangers), as well as certain non-financial businesses and professions with the exception of lawyers. The law specifically authorizes the DCCA to compel information and conduct on-site inspections (without a court order). The inspection manual for AML/CFT is not comprehensive (e.g., nothing on internal controls, no sample-testing of transactions, little guidance for assessing the adequacy of measures). The DCCA is now working on updating the inspection manual to take account of the new provisions of the MLA. Overall the DCCA's inspection policies and procedures, and practice (see also section on R. 32) for AML/CFT are not sufficient as regards scope.

636. Section 31 of the new MLA extends the requirement to register with the DCCA to currency 
exchangers and company service providers. While the law now provides for a fit and proper test for beneficial owners and managers of such undertakings, as well as money remitters, the provision does not apply to those persons and undertakings in existence as of March 1, 2006. That said, currency exchangers have been licensed by the police pursuant to the Trading Act and have been subject to a fit and proper test. The DCCA does not have a proactive program to identify and ensure the registration of informal remittance.

637. The DCCA has authority to issue secondary legislation for one provision under the law and although not provided for specifically in the MLA, it can issue non-binding guidelines. Regulation-making authority, however, is limited to notification, registration and public disclosure, including information that is to be registered, as part of its responsibility as registrar for money remitters and currency exchangers. One such regulation was issued under the previous MLA (Executive Order No. 837), which will be reissued mid-April, 2006 pursuant to the new act. As noted above, the FSA has broader regulation-making authority that is applicable to all persons or undertakings covered by the MLA, including money remitters and currency exchangers. It is nonetheless an anomaly that the DCCA, as a supervisor, has not been delegated similar regulation-making authority.

638. In coordination with the FSA, the DCCA is in the process of developing guidance for persons and undertakings under its supervisory responsibility.

639. In addition to ensuring compliance with the MLA, the DCCA is also placing emphasis on education, outreach, and on ensuring that registration requirements are enforced.

\section{Recommendation 30 (Structure and resources of the supervisory authority)}

\section{FSA}

640. The Danish Financial Supervisory Authority (FSA) is an agency under the responsibility of the Minister for Economic and Business Affairs. However, there is no visible evidence of any government or industry interference in the work of the FSA. The areas of responsibility of the FSA come under the auspices of three ultimate authorities; two councils for supervisory activities, and the Minister for Economic and Business Affairs for regulatory activities. These arrangements ensure that a Minister cannot exercise undue influence over the FSA. As such, the FSA would appear to have sufficient operational independence. 


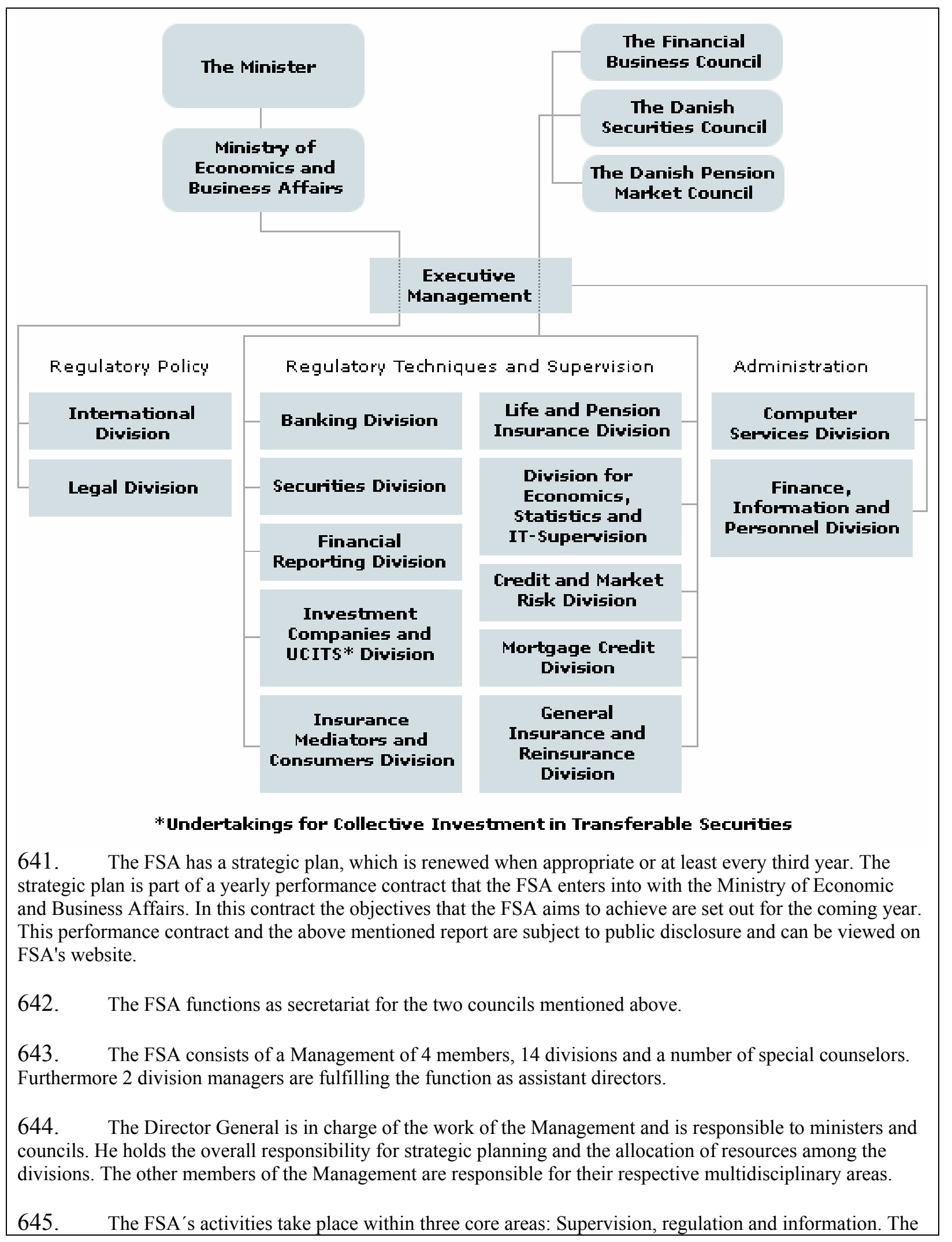


FSA would appear to be appropriately structured.

646. The FSA has a staff of 190 of which 130 are professionals. The FSA's supervision staff enjoys considerable credibility based on its expertise, professionalism, experience, and integrity. The turnover rate for all staff (i.e., professional and support) was 7\% in 2004.

647. As persons exercising a function within the public administration, staff are subject to the confidentiality requirements of Sections 27-28 of the Public Administration Act. Moreover, staff of the FSA are subject to conflict of interest and ethics provisions of Section 356 of the FBA. The FSA has also issued a set of ethical rules and guidelines applying to its employees. Legal protection for staff is currently not provided for in the FBA, but in the Act on Liability Claims which provides legal protection to all employees of all organizations for actions taken in good faith. Although there is no formal indemnification policy protecting employees against costs of defending their actions while discharging their duties, an employee will only be held personally responsible for an action performed for the FSA if the employee acts with gross negligence. In practice, personal liability for civil servants is close to non-existent, except in cases of willful misconduct. As such, staff of the FSA are required to maintain high professional standards.

648. Supervision can be divided into supervision of financial undertakings and supervision of the securities market.

649. The supervision of financial undertakings comprises banks, mortgage credit institutions, insurance companies, pension funds, insurance brokers, investment companies and investment associations (UCITS) and investment management companies, financial holding companies as well as the securities area.

650. Market supervision covers undertakings permitted to operate stock exchanges (securities exchanges), authorized markets, securities brokers, money market brokers, clearing undertakings and registration undertakings (securities centers).

651. One of the main tasks for the FSA is the drafting of financial laws (including the Money Laundering Act) and the issuing of executive orders.

652. The FSA collects and publishes statistics and key figures concerning the financial sector. This allows for comparison across the entire financial sector and thus supports management, clients and investors in evaluating the risk profile of each financial undertaking.

653. The FSA has the responsibility for the drafting and interpretation of the MLA. Since 2003 the banking division of the FSA has had the day-to-day responsibility for the MLA. Before that, the responsibility was in a regulatory policy division with no supervision responsibilities.

654. Money laundering inspections are made by the responsible divisions as a part of a full scope inspection. This means that the financial inspectors in all divisions (banking division, mortgage credit division, life insurance division etc.) have to be able to ensure that the institution in question is in compliance with the MLA. It is expected that the financial inspectors keep up to date with the relevant regulation. If a financial inspector in a certain division needs expertise on AML/CFT, the Banking Division provides assistance.

655. Although the FSA also has, in general, adequate freedom to deploy its supervision resources, its budget is incorporated into the overall budget of the government and subject to passage of the annual Finance Act despite the fact that the costs of the FSA are not paid by the state, but by the institutions under supervision.

656. The FSA makes an effort to devote the necessary resources to AML/CFT. The banking division of the FSA has specialist expertise in this area and has the daily responsibility for the interpretation and revision of the MLA and lends its support to the other divisions. 3 persons educated as lawyers are working daily with 


\section{AML/CFT.}

657. The expansion of the MLA and associated regulatory and supervisory responsibilities of the FSA will entail additional costs. According to the explanatory notes accompanying the Act, the workload is expected to increase by 2.4 person-years. Moreover, it is expected that there will be a need for some 1400 person-hours in the start-up phase for the new registration requirements and for the preparation of guidelines to the Act. In the first year, costs will amount to DKK 2.3 million (EUR 308,429), with DKK 1.4 million (EUR 187,739) for salaries and DKK 900,000 (EUR 120,690) for operation. Subsequently, costs will be DKK 1.7 million (EUR 227,969) per year with DKK 1 million (EUR 134,100) for salaries and DKK 700,000 (EUR 93.870) for operations.

658. While there is an expectation that the Finance Act will appropriate the funds necessary to cover these additional costs, these will come at a time when current staff resources will be stretched as a consequence the additional monitoring that will be required for banks with the implementation of Basel II. Moreover, a recent audit by the National Audit Office (NAO) found that further improvements, especially in the supervision of nonlife insurance, should be made. ${ }^{17}$ Specifically, the NAO noted that frequency of comprehensive on-site inspections needed to be shortened, particularly for large banks and insurance companies, the supervision of IT systems needed to be upgraded and the follow-up of inspections needed to be made more formalized and effective. Furthermore, the frequency and scope of AML/CFT inspections needs to be increased, particularly for the large banks, three out of five of which have not had an inspection or full review in this area.

659. Training on AML/CFT is undertaken as part of the basic training for financial inspectors. The efforts devoted to this (i.e., one hour of training) are insufficient and will need to be stepped up considerably, particularly in light of the expansion of the MLA.

\section{$D C C A$}

660. The Commerce and Companies Agency (DCCA) is an agency under the responsibility of the Ministry of Economic and Business Affairs. It enjoys operational independence under the MLA. Its actions or decisions can be reviewed by the Companies Appeal Board.

661. The Agency consists of a management of 5 persons and 10 sections. In total the staff consist of 230 people. As persons exercising a function within the public administration, staff are subject to the confidentiality requirements of Sections 27-28 of the Public Administration Act. Legal protection for staff is the same as for the FSA, i.e., the Act on Liability Claims which provides that staff are protected against suit while discharging their duties in good faith.

662. The responsibilities and activities of the Agency take place within three main areas: The administration of company and enterprise legislation, the registration of companies and disclosure of certain information and documents about companies, including company accounts and improving the conditions of the business community in particular by way of better regulation. Beyond that the Agency also controls and supervises some business areas such as accountants, real estate agents, home service companies, money remitters and public companies in different ways. 


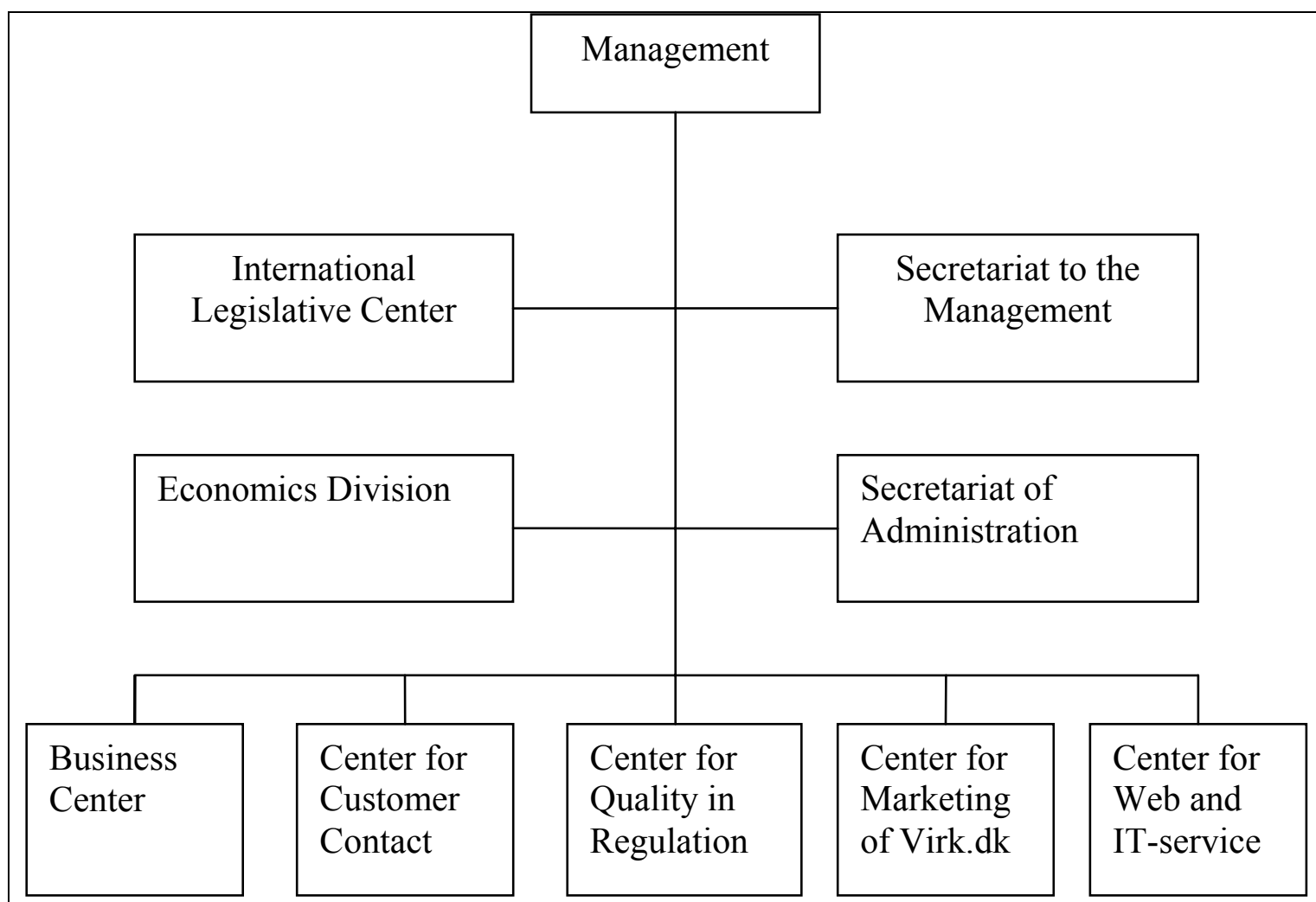

663. The Agency is also responsible for drafting commercial laws e.g. laws that regulate the different legal persons and other persons, e.g. real estate agents, accountants.

664. The agency is responsible for the administration and development of a number of legislative business acts including the Companies Act, the Company Accounts Act, the Commercial Foundations Act and the Act on Undertakings Carrying out Business for Profit. The agency is, furthermore, responsible for a variety of commercial laws applicable to certain types of business such as accountants, real estate agents, authorized translators, interpreters, and restaurants and hotels as well as the Home Service Scheme.

665. The second core responsibility of the agency is the registration of information and documents that must be filed under company law and related legislation in order to secure the incorporation, registration and striking-off of companies and other certain types of business. This also includes the responsibility to provide information to the public. To serve this purpose the agency keeps registers accessible to the public about public and private limited companies, commercial foundations, European Economic Interest Groupings, financial institutions (banks and insurance companies), co-operative societies, partnerships, commercial associations and a number of other enterprises with limited liability. The business community and other interested parties may, for a fee, gain access via the web site to updated information on more than 100.000 companies as well as retrieve copies of their annual accounts.

666. The Agency has a special unit which is working with supervision and monitoring in the AML/CFT field. There are currently seven people in the business center working with the MLA. Furthermore, there are three additional people involved in the work. They are based in the Center for Customer Contact, Center for Web and IT-service and in the management. At the moment 4 persons are working on money laundering inspections. They are all educated as lawyers.

667. Although the DCCA has, in general, adequate freedom to deploy its supervision resources, its budget 
is incorporated into the overall budget of the government and subject to passage of the annual Finance Act. 668. The expansion of the MLA and associated regulatory and supervisory responsibilities of the DCCA will entail additional costs. According to the explanatory notes accompanying the Act, the workload is expected to increase by 2 person-years. Moreover, it is expected that, in the start-up phase in 2006, there will be a need for a further person-year, DKK 0.5 million (EUR 67,050) for the establishment of a register plus DKK 0.5 million (EUR 67,050) for an information campaign. In the first year, costs will amount to DKK 2.89 million (EUR 387,548) of which DKK 1.35 million (EUR 181,034) will be salary expenses and DKK 1.54 million (EUR 206,513) will be operating costs. In subsequent years, costs will amount to DKK 1.26 million (EUR 168,966) of which DKK 0.9 million (EUR 120,690) are salary expenses and DKK 0.36 million (EUR 48,276) are operating costs.

669. This means that the DCCA has 4.5 person-years in 2006 (including the existing 1.5 person-years) and 3.5 person-years in the next years to administer the MLA. While this group can draw on the expertise existing within the other fields of legislation in the business center, it is doubtful that these resources will be sufficient to supervise money remitters and currency exchange given the DCCA's other supervisory responsibilities with respect to accountants, real estate agents and company service providers.

670. No specific AML/CFT training has been provided to staff, but the authorities have indicated that this is under consideration.

\section{$\underline{\text { Authorities' Powers and Sanctions - R. } 29 \text { \& } 17}$}

\section{Recommendation 29}

671. The FSA is responsible for regulating and supervising all financial institutions, except undertakings and persons that commercially carry out activities involving currency exchange or transfer of money and other assets (money remitters and exchange bureaus) which are regulated and supervised by the DCCA.

\section{Inspections and related powers}

\section{FSA}

672. Sections 344, 346,347 and 348 (part 21) of the FBA authorize the FSA to supervise financial undertakings, electronic money institutions and savings institutions as described in R. 23. Pursuant to Section 346(1) of the FBA, allows it to examine the circumstances of financial undertakings, including reviews of regular reports and on-site inspections of individual undertakings. This provision also applies to e-money institutions and savings institutions, cf. Sections 333 and 343 of the FBA. It also applies to foreign credit institutions, management companies and investment companies that carry out activities in Denmark through establishing branches or through offering financial services. Pursuant to Section 347(2), the FSA may at all times, on proof of identity and without a court order, gain access to these institutions and their branches with a view to obtaining information. This also includes inspections.

673. The FSA's powers to supervise insurance brokers are provided in the Insurance Mediation Act, part 10. Section 44(1) of the Act provides that the FSA has the authority to monitor insurance brokers for compliance with the Insurance Mediation Act. Section 47(1) provides that insurance brokers, on request, must provide the FSA with such information as is necessary to carry out the function of the FSA. However the FSA is not authorized to conduct on-site inspections. Supervision is carried out through the receipt of annual reports from insurance brokers.

674. As for investment associations and special-purpose associations, collective investment schemes, restricted associations, innovation associations and hedge associations, Section 118 of the Investment Associations Act authorizes the FSA to conduct on-site inspections without a court order. These entities must 
also provide information as is necessary to carry out the function of the FSA, cf. Section 119 of the Act.

675. While the FBA does not specifically authorize the FSA to supervise for compliance with the MLA, in practice the FSA has supervised most of the above entities for compliance in this regard ${ }^{18}$. Section 34 of the new MLA however clarifies the FSA's powers to supervise, as of March 1, 2006, the above entities for compliance with the AML/CFT requirements, in addition to other entities that were not previously supervised for AML/CFT compliance, i.e., credit card, leasing, factoring and other lending companies (i.e., finance/consumer credit companies). It also extends the FSA's powers to supervise insurance brokers by allowing it to compel information and conduct on-site inspections without a court order.

676. In particular, Section 34 of the MLA:

- Designates the FSA as the authority to ensure that the above persons and undertakings, including foreign undertakings' branches in Denmark, comply with the MLA and regulations issued pursuant to it.

- Requires persons and undertakings under the FSA's supervision to provide the information necessary for supervision of compliance with MLA or regulations issued pursuant to it.

- Authorizes the FSA to enter business premises, on proof of identity and without a court order, with a view to gathering information, including during inspections.

- Specifically authorizes the FSA to order that CDD and record-keeping requirements with respect to existing customers be implemented.

- $\quad$ Requires credit card, leasing, factoring and other lending companies (i.e., finance/consumer credit companies) to register with the FSA.

677. An on-site inspection of a bank/credit institution for AML/CFT compliance consists of a review of policies and procedures and a sample testing of verification of identity but not of transactions although there are no legal impediments for doing so. It also covers employee training programs. On-site inspections of insurance companies mortgage credit institutions, investment companies and investment associations also involves a review of policies and procedures, but no sample-testing, as the authorities view these sector as being of lower risk in terms of money laundering. While the FSA will be updating its inspection manual in light of the expansion of the MLA and its responsibilities under the Act, as noted above, current inspection policies and procedures are not sufficient.

\section{$D C C A$}

678. Section 1(1) no.4 of the previous MLA authorized the DCCA, as of January 1, 2004, to ensure compliance of undertakings involved with the transfer of money or other assets not otherwise supervised by the FSA (i.e., money remitters). It also required money remitters (including agents and sub-agents) to register with the DCCA, although it did not provide for a fit and proper for owners, directors or managers. According to Section 12 a. of the former MLA and Sections 1 and 5 of the Act on Due Process of the Administration Use of Coercive Measures and Duty of Disclosure (Act No. 442 of June 2004) respectively, the DCCA was authorized to compel information from undertakings and conduct on-site inspections of money remitters with 14 days notice to ensure compliance with AML/CFT requirements. In practice, the DCCA has exercised its supervisory role, conducting a number of on-site inspections of money remitter agents and sub-agents since early 2005.

679. Section 32 of the new MLA provides that, as of March 1, 2006, the DCCA is the supervisory authority for undertakings and persons that commercially carry out activities involving currency exchange, in addition to money remitters, for which it was already responsible under the previous law, as well as certain nonfinancial businesses and professions with the exception of lawyers.

680. In particular, Section 32 of the MLA:

- Designates the DCCA as the authority to ensure that money remitters and currency exchangers comply 
with the MLA and regulations issued pursuant to it.

- Requires persons and undertakings under the DCCA's supervision to provide the information necessary for supervision of compliance with MLA or regulations issued pursuant to it.

- Authorizes the DCCA to enter business premises, on proof of identity and without a court order, with a view to gathering information, including during inspections.

- Authorizes the DCCA to use external assistance for purposes of supervision.

- Requires money remitters and currency exchangers to register with the DCCA.

681. Most remitters are agents. It means that they are a part of a larger system, where the principal supplies the remitters (the agents) with manuals and IT-systems. The DCCA reviews the AM/CFT policies and procedures and of agents' awareness of these. The Agency also reviews books and records on verification of identity. At this stage, inspection policies and procedures are rudimentary. As noted above, the inspection manual for AML/CFT is not comprehensive (e.g., nothing on policies and procedures, no sample-testing of transactions, little guidance for assessing the adequacy of measures, although there are no legal impediments for reviewing these areas). The DCCA is now working on updating the inspection manual to take account of the new provisions of the MLA.

682. In addition to ensuring compliance with the MLA, the DCCA is also placing emphasis on education, outreach, and on ensuring that registration requirements are enforced.

\section{Powers of enforcement of FSA and DCCA}

683. Section 344 of the FBA enables the FSA to address compliance with laws and the safety and soundness of financial institutions under its supervision. The FBA permits the supervisor to apply qualitative judgment in forming his opinion. According to Section 347 of the FBA the supervisor has unfettered access to financial institutions' files in order to review compliance with internal rules and limits as well as external law and regulations. Based on this information, the FSA is free to assess the evidence and to formulate its judgment with regard to compliance of the supervised institutions with law and regulations and reach its own decisions whether and how to make use of its sanction powers under the FBA. The authorities assert that this is usually sufficient to ensure corrective action.

684. Section 350(1) of the FBA enables the FSA to take and/or require a financial institution to take supervisory measures. Furthermore, the FSA can revoke a bank's license if it violates prudential rules established by, or on the basis of, the FBA and remedial measures have not be taken within the specified time limit. Additional regulation for withdrawing a license is outlined in Sections 224(1) and 225(1), e.g., if a bank has not raised the capital required prior to the time limit set by the FSA.

685. Both the FSA and the DCCA have the power to express criticism in a written warning when an institution does not comply with the MLA. Furthermore, the FSA and the DCCA can order an institution to correct its way of conduct to be in compliance with the MLA. The authorities assert that this is usually sufficient to ensure corrective action. If not, the FSA must report the violation of the MLA to the police to initiate an investigation. The subsequent prosecution is a matter for the court (see section on Rec. 17).

686. The FSA has limited power to impose fines generally and with respect to AML/CFT compliance, it can only impose daily or weekly fines for failure to provide them with information necessary for the supervision of compliance. The amount of the fine is similarly not specified. While the FSA has the authority to remove a member of the board of management (or board of directors for that matter), which has never occurred due to non compliance with the MLA, often key members of management, e.g., chief compliance officer, are not members of the board and may not be removed. However, the FSA can require the board of directors to take remedial action in respect a specific function which may involve management changes.

687. Similarly, the DCCA has limited ability to impose fines. Like the FSA, it can only impose daily or 
weekly fines for failure to provide them with information necessary for the supervision of AML/CFT compliance. The amount of the fine is similarly not specified. The DCCA has no authority to remove senior management.

688. No fines have ever been imposed by the FSA or the DCCA for violations of the MLA. Following is the number and type of measures taken for non-compliance with AML/CFT requirements:

\section{FSA}

Number of measures taken by the FSA against entities for non-compliance with the MLA

\begin{tabular}{|c|c|c|c|c|}
\hline & 2002 & 2003 & 2004 & 2005 \\
\hline $\begin{array}{l}\text { Credit, E-money and } \\
\text { savings institutions }\end{array}$ & 0 & 2 & 12 & 25 \\
\hline $\begin{array}{l}\text { Foreign branches of credit } \\
\text { institutions in DK }\end{array}$ & - & - & - & 4 \\
\hline Life insurance companies & 0 & 0 & 0 & 0 \\
\hline Investment companies $^{1 /}$ & 2 & 5 & 5 & 4 \\
\hline Mutual funds ${ }^{2 /}$ & 0 & 0 & 0 & 0 \\
\hline Total & & & & \\
\hline
\end{tabular}

$1 /$ Includes asset management companies.

2/ Investment associations and special-purpose associations, collective investment schemes, restricted associations, innovation associations and hedge associations.

689. The increased number of measures taken against credit institutions in 2004 was due to the increased focus on the fight against money laundering and terrorist financing. In December 2004 the FSA wrote a letter to the Danish Bankers Association asking the association to urge its members to pay more attention to the obligations of the MLA. The measures taken consist of criticism for the lack of identification of customers and the lack of written internal rules on adequate control and communication procedures. The criticisms were followed by an order to come into compliance with the law. In some cases, the FSA has had to point out the requirements of the law to the institutions.

690. With respect to investment companies, the FSA has criticized the lack of identification of customers and the lack of written internal rules on adequate control and communication procedures.

\section{DCCA}

691. The DCCA found that two companies were not registered as they should be according to the MLA and took steps to ensure that they are registered. Both companies have had an on-site inspection. More recently, in February 2006 also notified the FIU of a money remitter for failure to comply with STR requirements.

\section{Recommendation 17 (Sanctions)}

\section{Criminal sanctions}

692. Under the previous MLA the sanctions system was based on a fine (criminal sanction) for failure to comply with requirements set forth in the law and associated regulations. Fines were applicable both for the case of intentional violation as well as in the case of negligence. Legal persons could also be held criminally liable. No sanctions were ever been applied under the previous Act.

693. The new act contains a more articulated (and partially different from the previous one) regime for sanctions, and provides a differentiation for the case of intentional or grossly negligent violation of a wide range 
of provisions, which attracts a fine, in contrast to imprisonment of up to six months for violation of a narrower range of provisions, in the case of particularly gross or extensive violations which are committed intentionally.

694. In the case of violations that attract only a fine, however, the fine applies only unless a more severe punishment is incurred under the Criminal Code. In this respect the explanatory notes make clear that it is a precondition for the application of the fines regime that the relevant person cannot be punished pursuant to another more serious provisions for the same acts or omissions. This means that, given the specific circumstances of the conduct, the relevant act/omission could also trigger section 290 or section 114 a, no. 3 of the Criminal Code (i.e., ML and TF respectively).

695. A significant change from the previous Act's sanction regime is that simple negligent violations of the provisions of the are now exempt from criminal sanctions. This decision was taken by the committee in charge for drafting the proposal of the new Act upon the suggestion of SØK and based on the experience in the implementation of the previous act.

696. As in the previous MLA, the amount of the fine is not specified. The type of fine is the "lump sum" one, which is among the "other fines" mentioned in section 51.3 of the CC. According to this provision, in order to determine the amount of the fine, special consideration should be given, within the limits relative to the nature and gravity of the offence, to the offender's capacity to pay, and to the obtained or intended gain or amount saved. These standards, however, would appear to be difficult to apply for a violation of the MLA, which seldom would imply a gain or saving.

697. Under the new regime a fine is applied for intentional or gross negligent violation of the following obligations (section 37.1):

a) Ban against cash transactions (section 2);

b) Obligation to investigate complex/unusually large transactions and relevant record keeping obligation (section 6.2, 2nd clause);

c) Obligation to report STRs related to ML or TF (section 7.1, 2nd clause)

d) In the case of ML and if the transaction has not been carried out, obligation to suspend it (section 7.3)

e) Obligation to suspend transaction in the case of suspicion of TF until the FIU has given consent for carrying the transaction out (section 7.4 , 1st clause)

f) Customer identification requirements (in the case of suspicion of ML or TF; section 11);

g) Customer identification requirements (when establishing relationships and in the case of doubts of veracity/adequacy); obligation to obtain information on intended business relationship and purpose and obligation to monitor customer relationship (section 12.1-6);

h) Timing of verification (section 13(1), 1st-3rd clauses, (2) and (3), 2nd clause);

i) Identification requirements in the case of occasional customers (section 14);

j) Identification requirement when transaction is carried out on behalf of a third party (section 15);

k) Obligations I the case of money transmission services (section 16.1);

1) Enhanced CDD requirements (section 19(1), (2), 1st clause and (3)-(5);

m) Record keeping requirements (section 23(1), 1st clause, (2) and (3), 1st clause);

n) Obligations in the case of branches/subsidiaries established in third countries (section 24);

o) Obligation on internal control and raining (section 25(1)-(3);

p) Tipping off (section 27(1);

q) Registration requirements (section 31(1) and section 34(2);

r) Obligation to provide information to DCCA and FSA (section 32.3 and 34.3);

s) Violations of section 35(2) on duty of confidentiality as regards feedback from the FIU, unless the matter is to be treated under the regulations of the Criminal Code.

698. In the case of intentional violation, particularly gross or extensive, of the obligation mentioned under a), c), d), e), g), i), j), k), m) the penalty can be increased to imprisonment of up to six months (section 37.2 ). The explanatory notes say that the application of the provision will be especially relevant in situations where it is not 
possible to adjudicate a conviction for money laundering, but where the provisions of the Act have been systematically violated, e.g. where (mainly) no identity information has been requested from customers or where information about customers or transactions have (mainly) not been stored. Moreover, the provision would be applicable if identity information has not been requested and/or stored for transactions involving particularly large amounts of money.

699. The examples indicated in the explanatory notes are those of a currency exchanger which, despite its knowledge of the requirements of the MLA, consistently does not request identity information when exchanging large amounts of money; or of a money remitter which does not store information about on whose behalf the transaction was carried out, or transfers money without closer investigation despite an employee's well-founded suspicion of financing of terrorism and does not report the transaction to the Public Prosecutor for Serious Economic Crime.

700. It is not clear why this provision, which provides for incarceration in some serious circumstances, would cover all violations of identification requirements, does not extend to a violation of the requirement to identify when there is a suspicion of ML or TF (which is only subject to a simple fine).

701. Since the amount of the fines is not specified, it would be difficult to conclude that they are effective, proportionate or dissuasive. Of more serious concern, however, is that not all the obligations set forth in the MLA are covered by a sanction. In particular:

- There is no direct sanction for non compliance to the obligation "to pay special attention to customers' activities which, by their nature, could be regarded as being particularly likely to be associated with money laundering and terrorist financing" and to investigate such activities, set forth in section 6 . The sanction is only for non compliance to the obligation to keep records of such investigation.

- There is no sanction in the case of failure to the obligation for the Danish Bar and Law Society (in the event that a lawyer has reported an STR to this body) to report the STR to the FIU.

- There are no sanctions for failure to comply to the requirements set forth in the case of reliance upon financial institutions licensed in a non-EU country or country with which the Community has not entered into an agreement for the financial area (section 17.2, which requires that the institution being relied upon be subject to AML/CFT requirements similar as the ones set forth in the Third EU Directive, and be subject to effective supervision of such requirements);

- There are no sanctions for failure to comply to the obligation to take measures to prevent that products/transactions that favor anonymity are used for ML/TF purposes (section 19 (6);

- 5)There are no sanctions for failure to comply to obligation to obtain sufficient information in the case of exemptions of CDD requirements (particularly when ascertaining that the customers is effectively covered by the exemptions, section 21.3), although, according to the authorities, the sanctions provided for failure to comply with the CDD process requirements could be used to cover this situation as well.

- Finally, it is interesting to note that the detailed regulations that the FSA can issue on the matters mentioned in art. 25.1 (CDD, internal control, reporting of STRs, record keeping etc.) will not contain sanctions for not compliance, as there is no reference to this power in the MLA (in particular in art. 37.3 which recalls the power of the FSA to stipulate sanctions in other regulations but this one).

702. A violation of the requirement to identify existing customers is not directly sanctionable. In such a circumstance the FSA has the authority to order the "proof of identity and the collection of the information" and only failure to comply with this order would result in a fine.

703. Section 37.3 contains an authority that regulations issued by the DCCA or the FSA pursuant to sections 10 and 33 respectively may stipulate a fine for intentional or grossly negligent violation of the provisions of said regulations. The provision basically extends to the DCCA the power that the previous MLA provided only for the FSA. 


\section{Administrative sanctions}

704. As described above for Rec. 29, the FSA and the DCCA have very limited power to impose fines to enforce AML/CFT compliance. They can only impose daily or weekly fines for failure to provide them with information necessary for the supervision of compliance. If an institution does not comply with an order to correct its way of conduct to be in compliance with the MLA, all the authorities can do is report the violation of the MLA to the police to initiate an investigation. The subsequent prosecution is a matter for the court and any possible fine (of which none has been assessed) would require a criminal procedure.

Market Entry -R. 23

705. Sections 7 and 14 of the FBA authorize the FSA to grant licenses to financial undertakings (subject to Core Principles) and Sections 223-225 authorize it to withdraw them. The FSA only grants a license when the owners of qualifying interests will not oppose appropriate and reasonable management of the bank or mortgagecredit institution. The FSA, thus, conducts a fit and proper evaluation on owners of qualifying interest. Section 14(1) no. 2 in conjunction with section 64 of the FBA provide evaluation criteria regarding the fitness and propriety (education, experience and professional qualification, and trustworthiness, including no prior criminal conviction for a violation of the Criminal Code or financial legislation where this would entail a risk that the duties are not carried out adequately) of the proposed board of directors and board of managers. The same applies for insurance intermediaries and investment associations, but not to e-money institutions or savings institutions. Pursuant to the FBA, the foreign banks and foreign entities of Danish banks are authorized to open branch offices and subsidiaries only after prior notification of the FSA.

706. According to Sections 61(1)-(2) and Section 62(1) of the FBA, the FSA must be notified and give authorization prior to any acquisition by a natural or legal person of a qualifying interest of 10 per cent or more in a financial undertaking or a financial holding company as well as of such increases in the qualifying interest which mean that said interest comprises or exceeds a limit of 20 per cent, 33 per cent, or 50 per cent, respectively of the voting rights or capital of the company, or that the financial undertaking or financial holding company becomes a subsidiary. Acquisition or increase of the interest is only authorized when such authorization is not contrary to ensuring appropriate operation of the financial undertaking or the financial holding company and, as such, the FSA conducts a fit and proper evaluation on owners of qualifying interest. Section 61 of the FBA also applies to e-money institutions but does not apply to insurance intermediaries and savings institutions.

707. Section 1(1) no.4 of the previous MLA required, as of January 1, 2004, the registration with the DCCA of money remitters, who were not otherwise under the supervision of the FSA, but it did not provide for a fit and proper for owners, directors or managers. Section 31 of the new MLA extends the registration requirement to currency exchangers who are licensed by the police, subject to a fit and proper test pursuant to the Trading Act. The DCCA must refuse to register these persons and undertakings if the members of management or the beneficial owners of the undertaking have been convicted of a criminal offence and such offence gives reason to believe that there is an immediate danger that the position or business may be abused, cf. Section 78(2) of the Criminal Code. However, the provision does not apply to those persons and undertakings in existence as of March 1, 2006.

708. Pursuant to Section 34 of the MLA, credit card companies, leasing and factoring companies not otherwise affiliated with banks, and other lending companies (i.e., finance/consumer credit companies) are subject to AML/CFT supervision by the FSA as of March 1, 2006. While Section 34 also requires such persons and undertakings to register with the FSA, there are no fit or proper tests for owners, directors or managers associated with registration.

\section{Ongoing supervision and monitoring}

Recommendation 23 (Criteria 23.4, 23.6, 23.7) 
709. Regulatory and supervisory measures that apply to financial undertakings that are subject Core Principles, apply for money laundering purposes as well. Under sections 7 and 14 of the FBA the DFSA is responsible for granting and under Sections 223-225 of the FBA for withdrawing banking licenses. The FSA only grants a license when the owners of qualifying interests will not oppose appropriate and reasonable management of the bank or mortgage-credit institution. The FSA, thus, conducts a fit and proper evaluation on owners of qualifying interest. Section 14(1) no. 2 in conjunction with section 64 of the FBA provide evaluation criteria regarding the fitness and propriety (education, experience and professional qualification, and trustworthiness, including no prior criminal conviction for a violation of the Criminal Code or financial legislation) of the proposed board of directors and board of managers. Pursuant to the FBA, the foreign banks and foreign entities of Danish banks are authorized to open branch offices and subsidiaries only after prior notification of the FSA.

710. Section 70 of the FBA and the guidelines pursuant to Section 71 of the FBA require banks to have detailed written policies for all significant areas of business, including appropriate internal controls. The guidelines under FBA Section 71 specify what these policy documents should cover. Where FSA has not issued minimum requirements in respect of other risks, as is the case for money laundering and terrorist financing, it still requires financial undertakings to establish their own risk parameters and during on-site inspections ensures that they observe them. The guidelines issued under FBA Section 71 require banks to ensure that all relevant staff are aware of the aspects of the bank's policies that affect them.

711. The Section 344 of the FBA authorizes the FSA to supervise financial undertakings. It also authorizes it to obtain information and obligates banks to provide it, to enter the premises of banks, and to carry out examinations to ensure compliance with the provisions of the Act. The Act requires banks to furnish periodic reports of their condition and other matters. While not specified in the FBA, the FSA has used its authority to supervise financial undertakings to ensure compliance with the MLA. Section 34 of the Act now clarifies that the FSA can compel information, conduct on-site inspections without a court order and requires financial institutions to cooperate with the FSA in order to ensure compliance with the Act.

712. The FSA has the authority to conduct consolidated supervision of banking groups, including groups where the parent is a holding company. It has used this authority to inspect foreign branches and subsidiaries of Danish credits institutions, including for compliance with AML/CFT requirements. The FSA has entered into effective arrangements with other supervisory authorities in the region to ensure the consolidated supervision of the major banking groups operating in Denmark.

\section{Money remitters and currency exchangers}

713. Section 1(1) no.4 of the previous MLA authorized the DCCA, as of January 1, 2004, to ensure compliance of undertakings involved with the transfer of money or other assets not otherwise supervised by the FSA (i.e., money remitters). According to Section 12 a. of the former MLA and Sections 1 and 5 of the Act on Due Process of the Administration Use of Coercive Measures and Duty of Disclosure (Act No. 442 of June 2004) respectively, the DCCA was authorized to compel information from undertakings and conduct on-site inspections of money remitters to ensure compliance with AML/CFT requirements with 14 days notice. In practice the DCCA has exercised its supervisory role, conducting a number of on-site inspections of money remitter agents and sub-agents since early 2005.

714. Section 32 of the new MLA provides that, as of March 1, 2006, the DCCA is the supervisory authority for undertakings and persons that commercially carry out activities involving currency exchange or transfer of money and other assets (money remitters and currency exchangers), as well as certain non-financial businesses and professions with the exception of lawyers.

715. In particular, Section 32 of the MLA: 
- Designates the DCCA as the authority to ensure that money remitters (confirming the previous law) and currency exchangers comply with the MLA and regulations issued pursuant to it.

- Requires persons and undertakings under the DCCA's supervision to provide the information necessary for supervision of compliance with MLA or regulations issued pursuant to it (thus confirming the previous law with respect to money remitters).

- Authorizes the DCCA to enter business premises, on proof of identity and without a court order, with a view to gathering information, including during inspections.

- Authorizes the DCCA to use external assistance for purposes of supervision.

- Requires money remitters and currency exchangers to register with the DCCA.

\section{Other financial institutions}

716. Pursuant to Section 34 of the MLA, credit card companies, leasing and factoring companies not otherwise affiliated with banks, and other lending companies (i.e., finance/consumer credit companies) are subject to AML/CFT supervision by the FSA as of March 1, 2006. While Section 34 also requires such persons and undertakings to register with the FSA, there are no fit or proper tests for owners, directors or managers associated with registration.

\section{Description of on-site supervision}

717. The FSA has chosen a risk-based strategy where intensive on-site supervision is given a high priority. An on-site inspection may be full scope, focused or follow up. While the following applies to banks, similar policies and procedures apply to other financial undertakings.

718. The on-site inspection program is split up into four components:

- Extended: Banks under increased surveillance (personal rating 1-3) full scope or focused every year.

- Special: Major banks and mortgage credit institutions with a risk area in focus every year, so that all significant risk areas have been reviewed within a 4-year period of time.

- General: Banks with rating 4-9 full scope every 4th year.

- Preventive: Very small banks with rating 4-9 full scope every seventh year.

Content of full scope inspection

719. A full scope inspection will consist of an examination of the following elements:

- Organization and strategy

- Board of directors

- Board of management

- Credit risk

- Market risk

- Legal risk

- Solvency and capital structure

- Accounting and budgeting

- Group structure

- Audit function and external auditors

- Prevention of money laundering and financing of terrorism

- IT risk

$\underline{\text { Reporting of an on-site supervision }}$ 
720. When an inspection is finished the procedure for reporting the results are the following:

- The results are first reported in a meeting with the board of management

- The FSA is obliged to hold a common meeting with board of directors, board of management, external auditors and, if applicable, the chief internal auditor.

- A written report is sent to the bank with criticism, orders and risk information

- A copy of the report is signed by the participants in the said common meeting and returned to the FSA.

721. Generally, inspections are full scope and cover the full range of risks and follow the procedures in the FSA's comprehensive inspection manual. In the case of larger banks, however, a supervisory program is designed which will cover a four year period, and examinations, which will take place at least once a year, will concentrate in depth on specific aspects deemed to be of high priority, but ensuring that over the four year cycle all significant risks are covered. Smaller banks are generally inspected once every four years unless the ratings described above indicate a shorter cycle. Very small and low risk institutions are normally visited only once in seven years. Foreign banks are also inspected often in conjunction with home supervisors.

722. While the FSA believes that it has adequate resources to assess the risks, visits to low risk institutions are relatively infrequent. Inspection teams are also modest in size. It is likely that this will be addressed in the government's response to the recent criticisms by the National Audit Board, not necesssarily by increasing resources but moving further in the direction of utilising resources more in proportion to the risks. However, it does not seem that AML/CFT risks have an important bearing on this decision, as such risks are not necessarily correlated to prudential risks, e.g., the smallest institutions may present little risk to financial stability but a higher risk of money laundering.

723. The DCCA supervises and conducts on site inspections to ensure compliance of money remitters (including individual agents and sub-agents) and currency exchangers with the MLA. The DCCA has indicated that it intends to work on the basis of a four-year inspection cycle.

\section{Recommendation 32}

\section{FSA}

Number of FSA inspections by type of financial institution

\begin{tabular}{|l|l|l|l|l|}
\hline & $\mathbf{2 0 0 2}$ & $\mathbf{2 0 0 3}$ & $\mathbf{2 0 0 4}$ & $\mathbf{2 0 0 5}$ \\
\hline $\begin{array}{l}\text { Credit, E-money and } \\
\text { savings institutions }\end{array}$ & 82 & 82 & 75 & 61 \\
\hline $\begin{array}{l}\text { Foreign branches of credit } \\
\text { institutions in DK }\end{array}$ & - & - & - & $5^{1 /}$ \\
\hline Life insurance companies $^{2 /}$ & 17 & 17 & 11 & 15 \\
\hline Investment companies $^{\mathbf{2}}$ & 4 & 6 & 8 & 6 \\
\hline Mutual funds $^{\text {Total }}$ & 1 & 3 & 1 & 6 \\
\hline
\end{tabular}

1/ First time on-site inspections have taken place. Before then, the FSA had only had regular meetings with branches.

2/ Includes asset management companies.

3/ Investment associations and special-purpose associations, collective investment schemes, restricted associations, innovation associations and hedge associations.

724. For credit institutions (banks and mortgage credit institutions), generally the interval of inspections is every 4 years as for the small and medium-sized banks (incl. e-money institutions and savings institutions). Regarding the large banks and mortgage credit institutions the inspections are not carried out as a complete 
inspection but instead an inspection of one area at the time. Consequently, the inspections do not always focus on the measures against money laundering and terrorist financing.

725. Branches and subsidiaries abroad of Danish credit institutions are also inspected. In 2005, one branch and two subsidiaries were inspected.

726. For life insurance companies, generally the interval of inspections is every seven years. If the company is part of a conglomerate the inspection takes place every four years.

727. For credit institutions, life insurance companies and investment companies, an inspection is carried out every year when an institution is considered to be high risk.

728. For mutual funds, the interval of inspections is every seven years. Investment associations/collective investment funds. normally market their products through securities dealers (credit institutions and investment firms), which have the contact with the investors and therefore deals with identification requirements etc.

\section{DCCA}

729. The DCCA started in 2005 to supervise money and value remitters and 20 have been inspected. At this time, 120 remitters are registered. The DCCA intends to inspect the remitters on-site every 4 years. At a later stage it will reconsider whether the cycle should be shortened.

\section{Recommendation 25 (Criterion 25.1)}

730. Limited guidance has been issued to date on how to comply with the MLA (e.g., the DCCA has issued a guideline on registration of money remitters). While the DCCA has issued guidelines on registration procedures, it has also issued general guidance concerning the MLA which has been available on the DCCA website since mid-2005. Both the FSA and the DCCA are currently developing guidance on the new MLA. The authorities expect to circulate draft guidance to reporting entities in the coming months.

731. The authorities have indicated that explanatory notes that are prepared in connection with tabled legislation are akin to guidelines. While these notes are intended to ensure that the members of parliament have adequate basis for assessing the reasoning behind a bill and its expected effects, they likewise assist the general public. The authorities note that the explanatory notes to the MLA are used by financial institutions and the bankers association guidelines draw heavily on them. However, explanatory notes are largely focused on explaining what is in the law rather than on, in addition to this, advising financial institutions and other reporting entities on how to implement it in the practical manner and are not in this sense a substitute for guidance.

Recommendations and comments 
732. FSA inspection policies and procedures, and practice for AML/CFT should be reviewed and improved as regards the scope and frequency of inspections. Similarly for the DCCA, inspection policies and procedures, and practice should be reviewed and improved as regards their scope.

733. The effectiveness of the powers of supervisory authorities to sanction for non-compliance should be reviewed.

734. Fit and proper criteria should be introduced for the registration of credit card companies, leasing, factoring and finance/consumer credit, and money remitters in business prior to March 1, 2006.

735. Detailed regulations and formal guidelines should be introduced to elaborate and clarify best practice for complying with the MLA.

736. Adequacy of current staff resources of the FSA allocated to AML/CFT should be reviewed given upcoming competing priorities and the need to increase scope and frequency of AML/CFT inspections.

737. Resources of the DCCA allocated to AML/CFT (notably for inspections of money remitters and currency exchangers) should be increased, given its other supervisory responsibilities for DNFBPs and the need to increase the scope of inspections.

738. Training of FSA and DCCA staff on AML/CFT matters should be considerably expanded.

739. Statistics on formal requests for assistance received and their disposition should be kept in better form to facilitate the review of effectiveness of cooperation.

\begin{tabular}{|c|c|c|}
\hline \multicolumn{3}{|c|}{ Compliance with FATF Recommendations } \\
\hline & Rating & Summary of factors relevant to section $\mathbf{3 . 1 0}$ underlying overall rating \\
\hline R.17 & $\mathrm{PC}$ & $\begin{array}{l}\text { - No sanctions have ever been applied under the previous Act. In the } \\
\text { absence of pre-set fines or range of fines and with no history of imposed } \\
\text { fines it is not possible to conclude that sanctions are effective, } \\
\text { proportionate or dissuasive. } \\
\text { - Not all the obligations set forth in the MLA are covered by a sanction. } \\
\text { Limited range of administrative sanctions to enforce compliance: very } \\
\text { limited authority to impose fines; ability to remove senior manager } \\
\text { beyond board of management is fairly limited and, in practice, relatively } \\
\text { few other actions have been have been taken to ensure compliance with } \\
\text { AML/CFT. }\end{array}$ \\
\hline
\end{tabular}




\begin{tabular}{|c|c|c|}
\hline $\mathbf{R . 2 3}$ & $\mathrm{PC}$ & $\begin{array}{l}\text { - Overall the FSA's inspection policies and procedures, and practice for } \\
\text { AML/CFT are not sufficient as regards scope and frequency. Similarly for } \\
\text { the DCCA, inspection policies and procedures, and practice are not } \\
\text { sufficient as regards scope. } \\
\text { - Absence of fit and proper tests for credit card companies, leasing, } \\
\text { factoring and finance/consumer credit, and money remitters in business } \\
\text { prior to March 1, 2006. } \\
\text { Limited regulation-making authority to set out more detailed requirements } \\
\text { for preventive measures. } \\
\text { The additional supervisory responsibilities (FSA: insurance brokers, credit } \\
\text { card companies, leasing, factoring and finance/consumer credit } \\
\text { companies; DCCA: particularly for currency exchangers but also money } \\
\text { remitters) - is too recent to be effectively implemented. }\end{array}$ \\
\hline $\mathbf{R . 2 5}$ & $\mathrm{NC}$ & - $\quad$ (NC for this section as well) Virtual absence of formal guidelines. \\
\hline R.29 & $\mathrm{LC}$ & $\begin{array}{l}\text { The additional supervisory responsibilities (FSA: insurance brokers, credit } \\
\text { card companies, leasing, factoring and finance/consumer credit } \\
\text { companies; DCCA: particularly for currency exchangers) - is too recent } \\
\text { to be effectively implemented. } \\
\text { - Limited range of administrative sanctions to enforce compliance: very } \\
\text { limited authority to impose fines; inability to remove senior manager } \\
\text { beyond board of management is fairly limited; limited authority to impose } \\
\text { fines and, in practice, relatively few other actions have been have been } \\
\text { taken to ensure compliance with AML/CFT. }\end{array}$ \\
\hline
\end{tabular}

\section{Money or Value Transfer Services}

\subsection{Money or value transfer services (SR.VI)}

\section{Description and analysis}

740. The previous MLA (section 1.4) required financial institutions and undertaking offering financial services to register with the DCCA insofar as their activities involve transfer of money and other assets.

741. The registration requirement is confirmed in the new Act (section 31.1.). The MVT service operators are subject to all AML requirements set forth in the AML in compliance to Recommendations 4-11. The new Act prohibits registration of MVT (among other undertakings) if persons, members, management or beneficial owner (if the service is provided by a natural person or a legal person, accordingly) have been convicted of a criminal offence and such an offence gives reason to believe that there is an immediate danger that the position or business may be abused (section 31.2. which recalls section 78 of the CC). If such a circumstance occurs the DCCA may activate the deregistration process, which is not final, however, until a court has pronounced a final decision and ascertained whether the circumstances set forth in section 78 of the $\mathrm{CC}$ are met.

742. The fit and proper test required by section 31.2 will not be applicable to those undertakings that were carrying out the MVT activities before the entry into force of the new Law. This raises problems of consistency with Recommendation 23. The authorities explained that the grandfathering provision would be based on a fundamental principle which is the non retroactivity of the law. This explanation, which was not backed by further elaboration by the authorities nor was it supported by case law, does not seem convincing. The prohibition of retroactivity principle applies only with reference to criminal offences, for those conduct which 
were committed before the entry into force of a criminal provision making the relevant conduct a crime; whereas in this case the matter is different and it relates to retroactivity of a fit and proper test that, though based on previous criminal convictions, does not create a new criminal provision.

743. The DCCA is responsible for monitoring the compliance of MVT operators with the MLA (i.e., with the registration requirement and preventive measures). It does so at the level of the agent and sub-agent. Although the targeted inspection cycle is appropriate, the scope of its on-site inspections is limited ( see paragraph 18 of previous section). In the course of its inspection activities, the DCCA routinely checks with MVT operators whether they have any dealings with informal remittance businesses. It has on several occasions encountered such businesses and has taken remedial action.

744. Carrying out transfer of money/other assets without having been registered is only subject to a fine, whose amount is not fixed the law and will be determined by the court. Such fines have never been applied, which makes difficult, in the absence of a pre-fixed amount, to determine whether the fines are proportionate or effective; however it would certainly appear that the sanction regime for violation of this requirement is not dissuasive in terms of deterrence.

\section{Recommendations and comments}

745. The DCCA should reconsider applying the fit and proper test requirements also to undertakings that were carrying out the MVT activities before the entry into force of the new MLA.

746. The DCCA's inspection policies and procedures, and practice should be reviewed and improved as regards their scope.

\section{Compliance with FATF Recommendations}

\begin{tabular}{|l|l|l|}
\hline \multicolumn{2}{|c|}{ Compliance with FATF Recommendations } \\
\hline SR.VI & Rating & Summary of factors underlying rating \\
\hline & LC & $\begin{array}{l}\text { Fit and proper test not applicable for money remitters in business prior to } \\
\text { March 1, 2006. }\end{array}$ \\
$\begin{array}{l}\text { The scope of inspection policies and procedures, and practice are not } \\
\text { sufficient. }\end{array}$ \\
\hline
\end{tabular}

\section{Preventive Measures-Designated Non-Financial Businesses and Professions}

\section{Customer Due Diligence \& Record Keeping}

\subsection{Customer due diligence (R.12) (Applying R.5,6,8-11 \& 17 (only sanctions for these Recommendations}

Description and analysis

General coverage

747. CDD obligations are applied to the following Danish DNFBPs under the new MLA:

- Accountants/auditors

- Real Estate Agents 
- $\quad$ Trust and Company Service Providers

- Lawyers (with restrictions and exemptions)

748. CDD obligations for Casinos are applied by the Gambling Casino Act of 1994 as amended in 2000 and 2005. Lawyers, accountants/auditors, and real estate agents were covered entities under amendments introduced to the old MLA in 2002.

749. The new MLA further prohibits "retailers and auctioneers" from receiving cash payments over EUR 15,000 and introduces changes into the "Act on Certain Means of Payment" which enables such a prohibition. While the term "retailers and auctioneers" is not defined in the MLA or the explanatory note, the authorities have stipulated that it is broader than dealers in precious metals and precious stones as required by FATF.

\section{Coverage issues}

750. The new MLA uses Danish categories to define these DNFBPs, which introduce a few non-critical distinctions with FATF materials. Specifically:

- Accountants - The new MLA extends obligations to "state-authorized public accountants and registered public accountants," and "other persons that otherwise commercially supply the same services, including tax advisors and external book-keepers." The authorities have stipulated that this would extend the MLA to unregistered accountants. Denmark's coverage of accountants is broader then required by FATF, in that it has not restricted the application of the MLA to accountants to the circumstances where they are performing gatekeeper functions as outlined in R. 12 (d).

- $\quad$ Trust and Company Service Providers - The new MLA creates the category of "Provider of Services for Undertakings," which it defines as any person, not already covered under the provisions for Lawyers and State-authorized or registered accountants, when they carry out a specified set of activities on a commercial basis. This set of activities mirrors, but does not exactly replicate, the activities stipulated in the FATF Glossary in that being or arranging for being a nominee shareholder for a publicly traded coming on a regulated market is not a covered activity. It should be further noted that Trusts (defined as revocable alienations of property) are not an acceptable legal form in Denmark.

- In practice, this distinction between CSPs who are lawyers and are not lawyers would not have a significant impact on CDD procedures, except in the cases that a lawyer was simultaneously (i) creating a company and (ii) representing a client, ascertaining a client's legal situation, or giving advice about instituting/avoiding proceedings. In those circumstances, a lawyer would be allowed to continue the relationship even if CDD could not be carried out.

751. The application of the MLA, including CDD requirements, to lawyers are restricted to circumstances where they are exercising R. 12 (d) gatekeeper functions. The MLA formulates these somewhat differently than FATF, but these distinctions are not critical (i.e., the MLA creates a distinction between carrying out a real estate transaction on behalf of a client and participating in the execution of a real estate transaction for a client but makes both actions covered activities; it also extends the coverage to including providing business advice). There is also a specific exception from coverage for lawyers and certain professions assisting them that relates only to Rec 5, Criterion 15 (see below).

752. The effectiveness of eliminating ML/FT risk in retail sectors by instituting a ban on cash transactions is as yet untested in Denmark. Market participants aver that such transactions were highly unusual in the previous period, and this anecdotal information implies that there would be limited incentives to evade the ban in the future. However, there is no evidence that a systematic analysis of past practice was conducted prior to instituting the ban. 
753. The implicit definition of casino in the Gambling Casino Act leaves "gaming halls" with more than 3 electronic gaming machines of restricted wager and payout and other establishments with 1-3 such machines outside the Danish money-laundering regime. In addition, the two legal providers of Internet gaming - the public benefit lottery "Klasselotteriet" (www.klasselotteriet.dk) and the state gaming agency Dansk Tipstjeneste Group (www.tips.dk) - are also not covered by any AML/CFT provisions.

754. DNFBPs in the Faroe Islands and Greenland are not subject to any AML/CFT requirements. This could be problematic in that lawyers in these jurisdictions appear to be able to offer their services to Danish residents as well.

\section{General CDD obligations}

755. CDD obligations for the categories of DNFBPs covered by the new MLA are the same as those for Financial Institutions and have the same strengths and weaknesses described in Sections 3.1 and 3.3, above. No executive orders or guidelines elaborating the new MLA have been issued for DNFBP sectors, although in practice Accountants and Lawyers do have Guidelines pertaining to the old MLA that could provide some guidance. The Copenhagen Casino has also issued Guidelines to its employees based on the old MLA.

\section{Applying R. 5}

756. Anonymous accounts would be effectively prohibited in theory and would also not be typical in the business practices of Danish DNFBPs

757. Danish casinos only conduct CDD at the door. This is supplemented by video registration which allows matching the customer's information to the video record of gaming and cashier transactions. Danish casino inspectors affirm that this linkage of video and customer information works well enough to insure the proper identification of customers based on visual characteristics. However, such linkage is not performed routinely, but only in the course of a given investigation after the fact. Moreover, as noted below, the recordkeeping requirements for the video records of gaming limit this retrospective analysis to the previous two months (at best). The requirements for initiation of CDD for other DNFBPs meets FATF requirements and the authorities and the industry representatives affirm that it takes place.

758. As with financial institutions, the specific documents and procedures required to establish and verify CID for DNFBPs are not specified in the MLA, although they are somewhat elaborated in the Explanatory Note. The Gambling Casinos Act also does not specify procedures. The old guidelines for Lawyers and Accountants and the Copenhagen Casino do provide some greater specificity (passports, drivers' licenses, etc), but they are not enforceable nor have they been updated yet to conform to the new MLA. As noted in 3.1, these requirements appear to be generally adequate for natural persons, but - in allowing reporting entities to rely on the information in the CVR to identify legal persons - makes the CID obligation indirect. Given that the CVR contains the necessary information, the only loophole created by this indirect obligation is small and would be limited to foreign legal persons, not registered in Denmark, whose domestic registers are not as comprehensive as the Danish CVR.

759. The requirements for identifying the beneficial owner in the MLA, as noted in 3.1, are adequate in theory, as the explanatory note elaborates the definition of beneficial owner to mitigate the overly rigid formulations in Section 3-4 (a-e). However, in practice, it is difficult to see how reporting entities will be able to get or especially verify such information for many legal forms - in particular privately owned companies and companies registered abroad. Many of the DNFBPs expressed particular concern about this provision in the law, which is new, and has not been elaborated in any executive order or even in unenforceable guidelines. This is particularly problematic in the case of lawyers, as banks are allowed to forgo identifying beneficial ownership for funds in accounts managed for a client by a lawyer (21-2). These issues raise concerns about whether these requirements can be effectively implemented and the recent entry into force of the MLA made this impossible to test. 
760. The procedure for $3^{\text {rd }}$-party transactions as described in Section 15 is slightly weaker than what is required in FATF EC 5.5.1 in that reporting entities are not required to determine whether all customers are acting for themselves (i.e. through a disclosure or declaration mechanism), but rather are enjoined to demand the information when they suspect that a customer is acting for another.

761. There are no provisions concerning beneficial ownership or $3^{\text {rd }}$ party operations in the legal material on casinos provided to the mission, although the rules for casino payouts minimizes the ML/FT risk of these technical gaps.

762. Section 12-4 of the MLA introduces a new obligation to ascertain the customer's objectives in starting the business relationship. Here, as with the provisions implementing Essential Criterion 5.5, effectiveness of implementation is still untested (see Section 3.2, above)

763. The provisions implementing Essential Criterion 5-7 were not yet in force at the time of the assessment mission.

764. The provisions implementing Essential Criterion 5-8 were not yet in force at the time of the assessment mission.

765. The simplified due diligence procedures in the MLA conform closely to FATF requirements. The FSA has not issued any further regulations expanding them. None of the specific exemptions in 20-1 would apply to DNFBPs and those in 21-1 should not introduce any additional ML/FT risk. As noted in relation to EC 5-6 above, the exemption for client's funds in lawyer's accounts puts a higher priority on the effective implementation of the CDD responsibility for lawyers. The issues with the MLA risk-adjustment procedures outlined in the explanatory note to Section 12-7 (noted in 3.1 above) would be equally problematic for DNFBPs dealing with customers who are legal persons. These provisions would need to be tested in practice, which has not yet happened. The possibility of simplified CDD is not contemplated in the Gambling Casino Act.

766. The exceptions for delayed verification of CDD in the MLA (Section 13-1) are (as noted in 3.1 above), generally in conformity with the FATF requirements. It is unlikely that any of the covered DNFBPs could make use of them, as they are limited to situations where performing CDD on time would interrupt the normal conduct of business.

767. The requirements to terminate relationships, refuse transactions, and consider making suspicious transactions reports apply to DNFBPs under the MLA, but the effectiveness of implementation is untested. Lawyers and accountants, real estate agents and company service providers who are assisting them have a limited exception to this rule. In those circumstances where the lawyer is both covered by the act and protected by privilege (see below), the lawyer and those assisting him are not obliged to terminate a business relationship or refuse to carry out a transaction if CDD can not be performed. Casinos under the Gambling Casino Act can and aver that they do refuse admittance to customers without appropriate identification material.

768. The requirements to apply CDD requirement to existing customers apply to DNFBPs under the MLA, but the effectiveness of implementation was untested at the time of the mission.

Applying Recommendation 6

769. The provisions implementing Recommendation 6 were not in force at the time of the assessment mission.

Applying Recommendation 8

770. No provisions explicitly implement Essential Criterion 8-1. Those implementing Essential Criterion 
8-2 were not in force at the time of the assessment mission

Applying Recommendation 9

771. The only forms of $3^{\text {rd }}$-party intermediation for CDD that are allowed under the MLA are those relating to insurance brokers, financial institutions either in Denmark, the EU, or other countries with AML/CFT requirements equivalent to the $3^{\text {rd }}$ EU ML Directive. The effectiveness of implementation of these provisions is as untested with DNFBPs as it is with Financial Institutions, and the weaknesses noted in 3.3 above concerning (i) the difference between required measures and measures being in place and (ii) the problems with enforcing obligations on $3^{\text {rd }}$ country institutions are equally true for DNFBPs. However, in practice, it is unlikely that any DNFBP would use these $3^{\text {rd }}$ party mechanisms so this is not judged to be a serious vulnerability.

\section{Applying Recommendation 10}

772. DNFBPs under the MLA are required to keep transaction information for 5 years, with the exception of information concerning the processing of unusual and complex transactions. The recordkeeping provisions concerning the latter were not yet in force at the time of the assessment missions. Casino gaming activity tapes are only preserved for 1 month and those from the cashier's cage only for 2 months. In those cases where the authorities' interest in a customer's activities develops later - perhaps as a result of an independent investigation of a possible predicate crime - this system could be insufficient to permit reconstruction of individual transactions to provide evidence for prosecution.

773. DNFBPs under the MLA and Casinos under the Gambling Casinos act are required to keep CDD records for 5 years.

774. Casinos are required to, and in practice do, provide timely information to the authorities on customers and transactions. The DCCA has the right to demand spot inspections of foreign exchange houses and money remitters but can only conduct inspections of accountants, real estate agents and company service providers with 14 days advance notice.

\section{Applying Recommendation 11}

775. The requirement to pay special attention to complex, unusual, and large transactions has been put into place by the new MLA, but there is no indication of how this is being implemented for DNFBPs.

776. The recording and recordkeeping requirements were not in force at the time of the assessment mission.

\section{Recommendations and Comments}

777. The legal and regulatory provisions for casinos and gaming should be updated to bring the CDD requirements in line with the international standard, including CFT provisions and CDD measures and application to internet gaming.

778. Establish clearer guidelines on appropriate identity verification procedures and documents (especially for legal persons).

779. Strengthen procedures for ascertaining beneficial owner information.

780. DNFBPs should be obliged to determine if a customer is acting on behalf of another customer, rather than taking actions when they suspect that to be the case. 
781. Casino procedures should be enhanced to provide identification of customers making transactions above the FATF-established threshold and to comply with FATF record-keeping requirements.

782. The AML/CFT regime should be extended to DNFBPs in Greenland and the Faroe Islands.

\section{Compliance with FATF Recommendations}

\begin{tabular}{|c|c|c|}
\hline & Rating & Summary of factors relevant to section 4.1 underlying overall rating \\
\hline R 12 & $\mathrm{NC}$ & $\begin{array}{l}\text { - In the case of a legal person, there is no requirement to verify that the } \\
\text { individual purporting to act on behalf of the legal person is so authorized } \\
\text { nor to identify and verify the identity of that person. Similarly the } \\
\text { requirements regarding the verification of the legal status are not complete } \\
\text { in the case of legal persons, as the information related to the CVR would } \\
\text { not encompass the provisions relating to the power to bind the legal } \\
\text { person. The same observations apply to the case of legal arrangements } \\
\text { (with reference to the name of the trustee and the power to bind the legal } \\
\text { arrangement). } \\
\text { - There is no indication of the types of documents which are to be verified } \\
\text { during the identification process. } \\
\text { There conditions under which DNFBPs are required to determine whether } \\
\text { the customer is acting on behalf of another person and to take reasonable } \\
\text { steps to obtain sufficient identification data to verify the identity of that } \\
\text { other person are too restrictive (this is required only if the institutions has } \\
\text { "knowledge or presumption"). } \\
\text { In the case of beneficial owners, there is no specification of the } \\
\text { information or data required for identification nor is there a clear } \\
\text { obligation to verify. } \\
\text { - The FATF requirements regarding ongoing due diligence and all those } \\
\text { related to the enhanced due diligence, PEPs, non-face-to-face transactions, } \\
\text { and unusual transaction reporting are not currently applicable. (They will } \\
\text { enter into force as of January 1, 2007). } \\
\text { - The FATF requirements regarding identification of the beneficial owner } \\
\text { and ascertaining a customers' objectives in starting a business relationship } \\
\text { have been recently established and not yet effectively implemented. } \\
\text { Casino legislation and procedures not in conformity with FATF standards } \\
\text { do not require identification of customers making transactions above the } \\
\text { FATF-established threshold and do not comply with FATF record- } \\
\text { keeping requirements. } \\
\text { DNFBPs in Greenland/Faroe Islands are not covered by AML/CFT laws } \\
\text { or regulations. }\end{array}$ \\
\hline
\end{tabular}

4.2 Suspicious transaction reporting (R. 16) (applying R13-15 \& 21) 


\section{General issues}

783. Certain of the CDD coverage issues mentioned above (Section 4.1) also apply to STR, i.e.:

- Casinos are covered by the Gambling Casino Act, other DNFBPs by the MLA.

- Dealers in precious metals and stones are not reporting entities, as covered behavior is prohibited.

- Significant numbers of DNFBPs in the Faroe Islands and Greenland are not covered.

- Non-casino gaming establishments are not covered.

784. Moreover, in addition to the limitations on coverage of lawyers noted in 4.1, they also have several distinctive features in their coverage and their reporting mechanisms:

Lawyers do not have to report information received in the course of either (i) defending or representing a client in or concerning judicial proceedings, including advising on instituting or avoiding proceedings, or (ii) determining the legal position of a client. This covers information either received from the client or from third parties about the client and pertains to information that may be received either before, during, or after the aforementioned proceedings or determination.

The explanatory note defines "determining the legal position of the client" as covering only the interpretation of current law and whether a specific behavior is legal or illegal.

This exemption from reporting does not apply where the lawyer knows that the client is trying to launder money or finance terrorism. It also does not apply where the lawyer is party to the crime, but the explanatory note reminds that protections against self-incrimination would prevail in such cases.

Lawyers who are members of the Danish Bar and Law Society may report suspicious transactions through the secretariat of the society. If the secretariat assesses that the transaction is subject to reporting obligations, it must immediately forward the report to the FIU. The secretariat interprets its assessment process as being limited to ascertaining whether the information falls under the privilege protection.

785. Accountants/auditors do not have a privileged relationship with clients under Danish law. However, they do enjoy a limited exemption from reporting under the MLA when (1) they are assisting lawyers while the lawyers are themselves exempt from reporting as described in paragraph 784 above or (2) the accountant/auditors are representing clients before the Danish National Tax Tribunal.

786. Real Estate agents also have a exemption from reporting when they are assisting lawyers while the lawyers are themselves exempt.

787. The distinction in the law between Company Service Providers who are lawyers and those who are not creates an anomaly in reporting in that those who are members of the Bar Society can report through that institution and those who are not must report directly to the FIU. As above, in the cases that a lawyer was simultaneously (i) creating a company and (ii) representing a client, ascertaining a client's legal situation, or giving advice about instituting/avoiding proceedings, the lawyer (and any associated accountant or real estate agent) would be exempt from reporting, while other CSPs would not.

788. Danish DNFBPs have not filed many STRs in the last 5 years:

\begin{tabular}{|l|l|l|l|l|l|l|}
\hline & 2000 & 2001 & 2002 & 2003 & 2004 & 2005 \\
\hline Lawyers & 0 & 0 & 0 & 6 & 9 & 6 \\
\hline Auditors \& Tax Advisors & 0 & 0 & 0 & 0 & 0 & 1 \\
\hline Real Estate Agents & 0 & 0 & 0 & 0 & 1 & 0 \\
\hline Casinos & 3 & 0 & 0 & 2 & 2 & 0 \\
\hline
\end{tabular}




\section{General reporting obligations}

789. STR obligations for the categories of DNFBPs covered by the new MLA are the same as those for Financial Institutions and have the same strengths and weaknesses described in Section 3-7, above, including the misalignment between the criminalization standard and the reporting requirement. As noted above, there are no current, enforceable executive orders or guidelines concerning AML/CFT issues for Danish DNFBPs.

790. DNFBPs in Greenland or the Faroe Islands have no reporting obligations.

\section{Applying R. 13}

791. The concerns mentioned above (Section 3-7) concerning the adverse effect of the MLA provision that limits the reporting obligation to those predicate offenses that carry more than one year's imprisonment are at least as problematic for DNFBPs as for Financial Institutions.

792. The reporting obligation for casinos is covered by Section 20(b) of the Gambling Casinos Act and Section 19-1 of the Executive Order on Gambling Casinos. These provisions introduce several stages in the reporting process between the covered entity and the FIU. First, the employee or manager is to notify the independent inspector in the casino, who - following a determination that the suspicion cannot be immediately disproved - notifies the police. The inspectors and Police in Copenhagen understand this to be the office which supervises the Casino rather than the FIU and the authorities indicated that most reporting from Casinos does come to them indirectly through the local police.

793. DNFBPs covered by the new MLA (except for lawyers, which report through the Bar Association) are required to report suspicions related to the financing of terrorism to the FIU, to the same extent and in the same manner as are financial institutions.

794. There is no terrorist financing reporting obligation in the Gambling Casinos Act but the Danish government has recently presented a bill to Parliament that will, when passed, create such an obligation.

795. The Gambling Casino act does not contain either a direct or indirect requirement to report attempted transactions, although this, too, is addressed in the proposed new legislation. As retail merchants are excluded from the scope of the legislation, they would not be obliged to report to the FIU any attempts to use cash in excess of the established threshold.

796. There is no exception for tax-related matters in the Danish MLA or Gambling Casino Acts.

\section{Applying R. 14}

797. All DNFBPs covered by the MLA, like employees of financial institutions (see section 3.7 above) are protected from liability for good-faith reports and are enjoined against disclosing that a report has been made to the FIU or that an investigation has been or will be instigated. However, the exceptions to this prohibition including those relating to lawyers and financial institutions communicating about shared clients, are not explicitly permitted under R. 14. A permissible exception is created in the case of lawyers, auditors, and tax advisors that allows them to discourage their clients from carrying out illegal activities. Similar provisions concerning protections from liability and prohibition of disclosure (with no exceptions) can be found in the Gambling Casinos Act (Section 20-b-3 and 20-b-4).

\section{Applying R. 15}

798. The requirement to establish internal rules concerning AML/CFT and to train their employees is as applicable to DNFBPs as it is to financial institutions (see above). However, DNFBPs are not required, as are 
financial institutions, to appoint a management-level compliance officer (MLA, 25-2), which is consistent with the standard. The Lawyers' and Accountants' guidelines are reported to be widely used by individual firms as the basis for their internal rules. As these have not yet been updated to reflect the changes in the new law, it is highly unlikely that either of these sectors are currently implementing this criterion adequately. The Real Estate Agents' association has also issued, and updated, guidelines for their members.

799. Lawyers and accountants must adhere to their respective Codes of Ethical Conduct to retain their professional standing and all Casino employees are fully screened by the Danish Police before hey are hired. The Association of Danish Real Estate agents does have a code of conduct, but adherence to it is not a requirement for practicing as an agent in Denmark.

$\underline{\text { Implementing R. } 21}$

800. As noted above, the new MLA contains no provisions directly implementing R.21 and no regulations have been issued by the FSA taking advantage of the option provided in Section 10 of the MLA.

801. The only SRO with a role in reporting is the Danish Bar and Law Society. Both the Society and the FIU report that cooperation is good.

Recommendations and Comments

802. While the legal and regulatory basis for the reporting requirement (with the exceptions noted below) is generally sound, the low level of reporting raises basic questions about the effectiveness of implementation.

803. Explore the possibility of removing the misalignment between the criminalization standard and the reporting requirement.

804. The reporting provisions of the new MLA should be extended to Greenland and Faroese DNFBPs.

805. The laws and regulations governing casinos should be enhanced to include reporting suspicions of terrorist financing. and consideration should be given to streamlining the reporting process.

806. Measures should be taken to enhance the effectiveness of the reporting requirement for DNFBPs, including improving outreach to the sectors and ensuring that internal procedures, training, and compliance arrangements are sufficient to ensure adequate and accurate reporting.

\section{Compliance with FATF Recommendations}

\begin{tabular}{|l|l|ll|}
\hline & Rating & & Summary of factors relevant to section 4.2 underlying overall rating \\
\hline R 16 & PC & $\bullet$ & Low level of reporting raises concerns about effectiveness of reporting by \\
& & DNFBPs. \\
& $\bullet$ & No Greenland/Faroe Islands coverage. \\
& $\bullet$ & No TF reporting in casinos. \\
\hline
\end{tabular}

\subsection{Regulation, supervision, and monitoring (R.24 and R.25.1)}

\section{Description and analysis}

807. The regulatory and supervisory regime for Danish casinos is highly decentralized. Each of the country's six casinos is under the supervision of police authorities in the municipality in which is it located. That supervision is directly effected by a team of independent inspectors who are present in the casinos during the time of its operation. There is usually one inspector present for each 10 hour shift. The inspectors are 
employees of the municipalities, financed by a special levy on the casinos, and report to the local police. The inspectors of one casino do not communicate routinely with the inspectors in the other casinos, although the relevant police responsible for oversight do meet occasionally (no more than twice a year). Licenses are issued by the MOJ, which conducts fit and proper tests - including checks for criminal records - for all proposed owners and managers. These are renewed if and when there are changes. All casino employees must also undergo checks of their criminal record, and must notify if their status changes.

808. Gaming machines and arcades and Internet gaming, which in large measure consists of participation in state lotteries and sports pools, are regulated and controlled by the Gaming Division of the Danish Tax Ministry. Danish authorities have been particularly assiduous in attempting to maintain the monopoly of regulated Danish Internet gaming providers on marketing to Danish citizens, utilizing the provisions of the Games, Betting, and Lotteries act of 2003 which make it illegal for foreign game providers to offer gaming targeted at Danish players. In addition, the Danish Tax Ministry approached the Australian Government in March, 2003, to request their help in restricting access by Danish citizens to Australian online gaming.

809. The casino inspectors do not conduct separate "on-site" inspections as they are always present in the Casinos. They are generally responsible for detecting violations of the Gambling Casinos Act and consider it to be their responsibility to alert the police to any indications of criminal activity. However, they do not focus on the strength of casino preventative measures - for example - by conducting spot-checks of the CDD system or other elements of the AML regime. Violations of the Gambling Casinos Act (including those provisions implementing the AML preventative measures) are punishable by a fine.

810. The AML/CFT supervision and regulation of lawyers is not specified in the MLA, but the explanatory note indicates that it falls to the Bar and Law Society under the provisions of the Administration of Justice Act (AJA). The sections of the AJA supplied (Section 126-127) require that lawyers operate in accordance with a code of conduct, not act in a manner unworthy of a lawyer, and authorize the Bar and Law Society to "issue rules on lawyers' duties relating to the handling of fiduciary funds, security against financial liability which may be incurred when practicing law and notification of all necessary accounting and financial information to the Danish Bar and Law Society as well as rules on the implementation of the requisite control measures."

811. The Bar and Law Society Code of Conduct only specifies money-laundering in one place, which appears to be limited to telling lawyers that they should refuse clients when they suspect that their advice will be used to help launder money. ("Provided a lawyer in connection with his client's request for assistance gets probable cause to believe that the clients purpose is to misuse the lawyers counselling in order to promote a criminal offence such as money laundering, the lawyer must not take on the task. This also applies if the performance of the task involves a disregard of good conduct, cf. the Danish Administration of Justice Act, Section 126..(Unofficial Bar Association Translation”)

812. The Bar and Law Society has also issued specific guidelines for lawyers in the area of MoneyLaundering. These would not appear to be among the list of activities on which the AJA authorizes them to issue rules, which raises a question about the legal basis for their supervisory role in this area.

813. In actual practice, the AML/CFT supervision of Danish lawyers by the Bar and Law Society is not robust. It appears to be limited to the issuing of these guidelines, which are currently awaiting updating to conform to the new MLA. Specifically, the Bar and Law Society does not inspect its members for their implementation of AML/CFT preventative measures.

814. No other Danish DNFBPs were supervised for compliance with AML/CFT preventative measures prior to March 1, 2006 and plans for implementing such supervision were still nascent at the time of the mission. The DCCA, which is the authority vested with this responsibility (MLA 32-2), already performs a supervisory role vis-à-vis registered accountants/auditors through a subordinate body known as the Revisortilsynet. This 
could provide a useful basis for examining their AML/CFT compliance as well, but it would not help with unregistered accountants, which will be a new population for the DCCA and the coordination between these two functions is complicated by the fact that the non AML/CFT supervision is currently financed by a special fee on the accounting/auditing firms.. As far as Real Estate Agents and Company Service Providers are concerned, no work has yet been done to implement the new supervisory functions.

815. It should be noted that the explanatory note to the law only allocates an additional two person years for all the new functions that will be required of the DCCA, of which DNFBP supervision is only a part, which raises questions about the adequacy of resources. Moreover, the MLA does not give the DCCA the right to gain access to any DNFPB premises without a court order.

816. Finally, the DCCA does not have regulation-making authority over the DNFBPs it supervises. That authority rather rests with the FSA (25-5). While both sets of authorities were confident that this divided responsibility would not create any difficulties for them, it does further complicate an already sub-optimal set of practices.

817. As noted above, the Bar and Law Society and the Association of State-authorized accountants and the Association of Chartered Estate Agents did issue guidelines to assist their members in complying with the earlier MLA. Both bodies have indicated that they plan to update their guidelines, but at the time of the mission this had not taken place. The only guidelines for Casinos that were presented to the assessment team would more fall into the category of internal rules issued by the management of the enterprise.

818. While representatives of DNFBP SROs and Associations appeared to be generally familiar with their obligations under the new law, the complexity and novelty of some of the provisions would argue that supervisors and other authorities should enhance outreach and training for DNFBP practitioners, especially those not covered by the previous MLA.

\section{Recommendations and Comments:}

819. Casino inspectors should also monitor casino compliance with AML preventative measures (and CFT when the legal basis is changed).

820. The Bar and Law Society should more directly engage in the supervision of its members for compliance with AML/CFT preventative measures under the MLA.

821. The DCCA should move forward decisively to put supervision of other DNFBPs in place.

822. Planned resources for the DCCA will not be sufficient to effectively supervise DNFBPs, given the DCCA's other supervisory responsibilities for money remitters and currency exchange and the need to increase the scope of inspections.

823. All professional associations should update their guidelines in light of the new MLA, with the active participation of the FIU, FSA, and DCCA.

824. Competent authorities and supervisors should enhance outreach and training on AML/CFT issues and obligations for DNFBP practitioners.

\begin{tabular}{|l|l|ll|}
\hline \multicolumn{2}{|c|}{ Compliance with FATF Recommendations } \\
\hline & Rating & & Summary of factors relevant to section $\mathbf{4 . 3}$ underlying overall rating \\
\hline R24 & NC & $\bullet$ & Major shortcomings in current supervision all DNFBPs \\
\hline R25 & NC & $\bullet$ & Absence of guidelines from the competent authorities, except for lawyers (but \\
\hline
\end{tabular}




\subsection{Other non-financial businesses and professions-Modern secure transaction techniques (R.20)}

\section{Description and analysis}

825. There is a ban on cash transactions over DKK 100,000 (EUR 13,410) that extends to all retail establishments, including other high-value/luxury goods dealers, auction houses, and pawnshops. While not specifically covered by the FATF Recommendations, if enforceable, this measure would appear to reduce the risk of money-laundering.

826. Denmark is a pioneer in promoting and supporting non-cash payment systems. The DanKort, a nationwide debit card system, is routinely used for all forms of retail transactions and has significantly reduced the use of cash in the system. DanKort transactions have more than tripled in the last 15 years, now equaling $14.13 \%$ of GDP and almost $30 \%$ of private consumption.

\section{Recommendations and comments}

\section{Compliance with FATF Recommendations}

\begin{tabular}{|l|l|l|}
\hline \multicolumn{1}{|c|}{ Rating } & Summary of factors underlying rating \\
\hline R.20 & $\mathrm{C}$ & \\
\hline
\end{tabular}

\section{Legal Persons and Arrangements \& Nonprofit Organizations}

\subsection{Legal Persons-Access to beneficial ownership and control information (R.33)}

\section{Description and analysis}

827. Danish legislation allows for the formation of several kind of legal persons. In general, all these legal persons have full legal capacity. However in some cases the entity is not recognized as legal person until it has been registered. Businesses in Denmark are registered in different registers based on the nature of the entity. All business are also registered in the Central Business Register (CVR). The data entered in the CVR is available to the authorities and the public, including online. However, with one exception, the CVR contains no information on beneficial ownership. For some entities, limited beneficial owner information may be available in private registers such as company books. Public companies can issue bearer shares up to their entire capital. In such instances information on beneficial ownership is available only for shareholders that have holdings above a designated threshold.

Type of legal persons and provisions about information on beneficial ownership

828. Danish legislation allows for the formation of the following legal persons:

- Public companies (aktieselskaber, A/S). (Number: 39.406).

- Private companies (anpartsselskaber, ApS).(Number: 119.025).

- Companies or associations with limited liability (selskaber og foreninger med begrænset ansvar, S.M.B.A/F.M.B.A.).

- $\quad$ Limited liability co-operatives (andelsselskaber, A.M.B.A.).

- Limited partnerships (kommanditselskaber, K/S).

- Partnerships with personal liability of partners (interessentskaber, I/S).(Number 3-6: 4.627). 
- $\quad$ Commercial foundations. (Number: 1.234).

- European Economic Interest Grouping (EEIG). (Number: 15).

- European Companies (SE). One Danish company has merged to a SE with its registered address in Sweden.

829. In general, all these legal persons have full legal capacities. However in the case of $\mathrm{A} / \mathrm{S}, \mathrm{ApS}$, V.M.B.A., A.M.B.A., commercial foundations, and EEIG, the entity is not recognized as legal person until it has been registered.

830. An A/S has a board of directors which must consist of at least three members, elected by the general assembly. The board of directors must appoint a board of management which must have at least one member. The majority and the chairman of the board of directors must not be members of the board of management. The structural and organizational possibilities of the legal personality of an $\mathrm{A} / \mathrm{S}$ are regulated by special legislation, the Danish Public Companies Act (aktieselskabsloven, DPCA).

831. The A/S must have a share capital of minimum DKK 500,000 (EUR 67,050) which shall be fully paid-up, in cash or in kind before registration. The company may be formed by one or more founders. There are no residential requirements for the founders, the members of the board of directors and/or of the management board of an A/S. All individuals appointed to boards as well as auditors of company must be registered with DCCA.

832. The articles of association shall include provisions about, among others, the name of the company; the local authority in Denmark in which the company is to have its registered office (head office); the objects of the company; the amount of the share capital; the denomination (nominal value) of the shares and the shareholders' voting rights; the number or the minimum and maximum number of members of the board of directors and any alternates for such members as well as the term of office of the members of the board of directors; the number or the maximum and minimum number of auditors as well as the term of office of the auditors; whether the shares are to be made out to a named holder or may be made out to bearer. The memorandum of association includes, among other, information and provisions about the names, occupations and addresses of the promoters.

833. There are requirements for keeping a register of shareholders, in which the name of the holders of registered share is to be registered (section 25 of DPCA). In the registered share has changed hands the new shareholders has only a faculty (not an obligation) to make a request to the company that his/her name is entered in the register of shareholders, upon proof of title (section 25.3). However the transferee of a registered share cannot exercise the rights conferred to a shareholder unless his name has been recorded in the register of shareholders or he/she has notified the company of the acquisition and proven the title (section 27); however this does not apply to the right of receive dividend or any other disbursements. The register of shareholders is open to inspection by public authorities, according to section 26.2 of the DPCA.

834. The $\mathrm{A} / \mathrm{S}$ can also issue bearer shares, up to the whole capital of the company. In such case there is no requirement to disclose the name of the holder of the bearer shares unless nor to keep bearer shares holders' names in share registrar except in the circumstances set forth in section 28a of the Danish Public Company Act. This provision obliges anyone holding shares in a A/S to give notice to the company:

- if voting rights represent $5 \%$ or more of the voting rights or if the nominal value of shares represents $5 \%$ or more of the share capital;

- whenever any changes occur to a previously notified situation according to certain fixed standards.

In such circumstances notices must be kept in a separate register, which is open to inspection to DCCA and various subjects and, in the form of a transcript, to the general public. 
835. An ApS may have a board which can consist of one member only. The structural and organizational possibilities of the legal personality of an ApS are regulated by special legislation, the Danish Private Companies Act (anpartsselskabsloven). Incorporation requirements are like those provided for an A/S except that the share capital minimum is DKK 125,000 (EUR 16,762). The company may only pay the preliminary expenses to the extent that the costs can be covered by the amount which the company has received on the subscription for the shares in excess of the nominal value of the shares. There are no residential requirements for the founders, the members of the board of directors and/or of the management board of an ApS.

836. The articles of association must at least include provisions about the name and any secondary names of the company; the local authority in Denmark in which the company is to have its registered office (head office); the objects of the company; the amount of the share capital; the shareholders' voting rights; the management of the company; the accounting reference period of the company and the appointment of the auditor (section 5 of DPCA).

837. The memorandum of association must include provisions about the names and addresses of the promoters, the members of the management board and the auditor of the company; the allotment of shares to the individual promoters; the issue price of the shares; and the costs incurred in connection with the formation which the company is to discharge.

838. The ApS is required promptly after the company is formed to create a register of members; which, according to section 16.2 of the DPCA, must state the name and addresses of all shareholders, as well as the nominal value of their shares. There is an obligation to notify the company in the case of share changing hands or being pledged and to register the change in the register. According to section 17.2 the register is open to inspection by both shareholders and public authorities. If all shares are held by a single shareholder or cease to be held by a single shareholder, a notice to this effect stating the full name and address or, for companies, the registered office of the single shareholder shall be given to the company not later than four weeks after such event. Such information is available to the public.

839. A S.M.B.A/F.M.B.A. is a company that can be established with no capital requirements nor governance rules. This type of company is not regulated in detail by special legislation, but it is subject to the requirements set forth in the Danish Act on Undertakings Carrying on Business for Profit (lov om visse erhvervsdrivende virksomheder), which is applicable to a number of limited liability businesses without specific, in-depth legislation. The Danish Act on Undertakings Carrying on Business for Profit regulates key issues such as name, powers of procuration of the undertaking, registration and legal personality, annual accounts and auditing and dissolution.

840. The promoters must draw up articles of association and/or lay down the name, address, objects of the company, the accounting period of the company and who has the right to sign for the company. It is not clear if in this case there are rules of disclosures concerning the beneficial owners of the company. It is not clear if in this case there are rules of disclosures concerning the beneficial owners of the company.

841. An A.M.B.A. is regulated by the Danish Act on Undertakings Carrying out Business for Profit. Its objects must be to help promote the common interests of the members through their participation in the business activities as buyers, suppliers or in any other, similar way, and whose profit, other than normal interest on the paid-up capital, shall either be distributed among the members in proportion to their share of the turnover or remain undistributed in the undertaking.

842. The promoters must draw up articles of association and/or lay down the name, address, the objects of the company, the accounting period of the company and who has the right to sign for the company. As limited liability company A.M.B.A. must file annual accounts. It is not clear if in this case there are rules of disclosures concerning the beneficial owners of the company. 
843. In a K/S one or more members, the general partners, are personally and jointly and severally liable, without limitation, for the debts and obligations of the undertaking, whereas one or more members, the limited partners, have limited liability for the debts and obligations of the undertaking. A K/S is regulated by parts of the Danish Act on Undertakings Carrying out Business for Profit, with regards to name and powers of procuration of the undertaking.

844. The $\mathrm{K} / \mathrm{S}$ is formed by an agreement between the participants. This is only regulated by the general law of contracts.

845. If all fully liable partners of limited liability partnership are limited liability companies limited liability partnership must be registered with the DCCA.

846. In an I/S all members are personally and jointly and severally liable, without limitation, for the debts and obligations of the undertaking. An I/S is regulated by parts of the Danish Act on Undertakings Carrying out Business for Profit, with regards to name and powers of procuration of the undertaking. The $\mathrm{I} / \mathrm{S}$ is formed by an agreement between the participants. This is only regulated by the general law of contracts.

847. A commercial foundation can only distribute funds to receivers or objectives that fulfill the purpose described in the articles of associations. Amendments to the articles of association can only be made with the permission of the foundation authority, the DCCA, and the consent of the minister of Justice. A commercial foundation has a board of directors which must consist of at least three members and may have a board of management. The majority and the chairman of the board of directors must not be members of the board of management. The structures and reorganization possibilities of the legal personality of a commercial foundation are regulated by special legislation, the Danish Act on Commercial Foundations (lov om erhvervsdrivende fonder).

848. The commercial foundation must have a capital of minimum DKK 300,000 (EUR 40,230) that must be fully paid-up. The promoters must draw up articles of association that state the name of the foundation, its promoters, its registered office, its objects, the amount of capital and how it is paid-up, any special right for the promoters or others, the number of board members and how the procedure of election, accounting issues including the accounting period of the company and the appropriation of profits.

849. An EEIG is regulated by Council Regulation (EEC) No 2137/85 of 25 July 1985 on the European Economic Interest Grouping (EEIG) and the Danish Act on Administration of the EEC Regulation introducing European Economic Interest Groupings. The regulation stipulates that the purpose of a grouping shall be to facilitate or develop the economic activities of its members and to improve or increase the results of those activities; its purpose is not to make profits for itself. Its activity shall be related to the economic activities of its members and must not be more than ancillary to those activities.

850. An EEIG must be formed by at least two parties, companies or natural persons, who carry out any industrial, commercial, craft or agricultural activity or who provide professional or other services in the Community. The parties remain independent persons as well as parties of the EEIG. The parties must conclude a contract that stipulates the name of the grouping, the official address of the grouping, the objects for which the grouping is formed, the name, business name, legal form, permanent address or registered office, and the number and place of registration, if any, of each member of the grouping and the duration of the grouping, except where this is indefinite.

851. A European Company is regulated by Council Regulation (EEC) No 2157/2001 of 8 October 2001 on Statute for a European Company and the Danish Act on Administration of the Regulation. The Regulation stipulates that it will permit the creation and management of companies with a European dimension, free from the obstacles arising from the disparity and the limited territorial application of national company law. The 
essential objective of legal rules governing Sees is to enable companies from different Member States to merge or to create a holding company and enable companies and other legal persons carrying on economic activities and governed by the laws of different Member States to form joint subsidiaries.

$\underline{\text { Tax, accountancy related information/requirements }}$

852. The names of $\mathrm{A} / \mathrm{S} \mathrm{ApS}$ and $\mathrm{K} / \mathrm{S}$ owners are not registered in the CVR. However this information is obligatory entered in the annual Denmark tax reports. Tax information is fully available to the public authorities. Companies which have limited liability must file their audited accounts for each 12 months period with DCCA must file their audited accounts for each 12 months period with DCCA .

853. The Danish Bookkeeping Act stipulates that accounting records and books must be kept for five years from the end of the accounting period the records or books concern. There is one exemption for retailing firms cash register tape and similar internal records must be kept one year from the date of signing the annual report they concern.

854. The Danish Bookkeeping Act applies to all legal persons except those who are non-commercial, not liable to taxation or duty, and not required to give financial information to qualify for grants from the EU or from the public sector of Denmark.

855. Legal persons are regulated by the Danish Financial Statements Act (årsregnskabsloven). According to the Act most legal persons are obliged to have their annual financial statements audited by an accountant and to send it to the DCCA. The Agency makes it public. The Financial statements are spot checked by the Agency.

\section{$\underline{\text { Registration requirements and competent authority }}$}

856. Businesses in Denmark are registered in different registers based on the form of the undertaking; all business are also registered in the Central Business Register (CVR) and assigned an 8 digit identification code (the CVR number). There are approximately 580.000 businesses registered in the CVR.

According to section 2. of the DACBR the purpose of the Central Business Register is:

- to contain core data on legal entities that engage in business or are employers, and the production entities associated with them;

- to implement clear and unambiguous numbering of the legal entities and associated production entities contained within the registry (the CVR number)

- $\quad$ to make the core data available to public authorities and institutions as well as to private parties.

857. The Central Business Register is established under the supervision of the Ministry of Economics; Denmark Bureau of Statistics is responsible for the administration of the register and, in conjunction with the Ministry of Labor, the DCCA and Central Customs and Tax Administration manages the activities of the register.

858. The Central Business Register collects all data contained in the other registers (which are held by the DCCA and the Tax authorities); regarding registration requirements the provisions detailing the information which is to be requested, the obligation to disclosure certain circumstances (such as change in the ownership/control or management structure) as well as the powers available to the competent authorities (the DCCA) are scattered in several pieces of legislation.

859. In particular, the DCCA has the responsibility to register A/S, ApS, branches, A.M.B.A., S.M.B.A./F.M.B.A. and commercial foundations. 
860. The relevant legislation concerning the CVR is:

- The consolidated act no. 598 of $22^{\text {nd }}$ of June 2000, Danish Act on the Central Business Register (DACBR), and

- $\quad$ Order no. 977 of $17^{\text {th }}$ of October 2005 of the above mentioned law.

861. According to the information provided by the DCCA the type of businesses registered in the CVR are:

One-man business

Estate of a deceased person

Partnership

Limited partnership

Shipping company

Public limited company

Foundation

Commercial foundation

Association

Voluntary association

Co-operative society

Limited co-operative society

A limited association or company

European economic firms

Foreign branch of a public limited company, limited partnership company

Foreign branch of a private limited company or company

Branch of a foreign limited undertaking

Branch of other type of foreign enterprises

Other foreign undertakings

Established place of business of an European economic undertaking

Government administrative unit

County authority

Municipality

Parish Church Council

European Companies

862. According to section 11 of the DACBR, the information contained in the Central Business Register comprise, among others:

- $\quad$ Entity's CVR number;

- $\quad$ Form of business organization;

- $\quad$ Commencement date;

- Termination date;

- $\quad$ Business name;

- $\quad$ Business address;

- $\quad$ Name, address, position, and CPR or CVR numbers of full-liability partners (this applies only in the case of businesses that are in the form of full liability partners, like I/S);

- Type of business activity and types of sub-activities, if any.

863. Section 17 of the DACBR provides for a general right, upon written request, to obtain access on the core data on file in the CVR (with some restrictions, such in the case of the CPR of full liability partners. 
864. However, no information on the beneficial owner of the business (with the exception of the I/S), is directly available on the Central Business Register. For A/S and ApS, information about beneficial ownership is available in some circumstances in private registers such as company books. The authorities rely on the investigative powers and on inspection powers to obtain the information on beneficial ownership which can be obtained in a timely manner and shared with other authorities. However the information that can be obtained (either in the company books or in the various registers where the companies are registered) might not be up to date; such as in the case of transfer of registered shares, where the new owner might not be registered in the company books, if he/she decides not to exercise the right to vote (see paragraph 7 in this section) or in the case when the original promoters of the company (whose names are in the article of association deposited for registration) sell their quotas. Besides, in the case of foreign companies registered in Denmark, beneficial ownership information is not available.

865. As previously mentioned, registration requirements for establishing companies and foundations are scattered in several pieces of legislation.. According to the DCCA A/S, ApS, S.M.B.A., K/S/ and I/S are registered with this agency.

866. For $\mathrm{A} / \mathrm{S}$ and $\mathrm{ApS}$ the following information must be made available for registration:

- Starting date

- Name of company and address in Denmark

- Name, address, occupation CPR number of members of the Management Board, the Board of Directors, and the Chairman.

- Name and address of accountant

- Articles of association and fiscal year

- The object of the company

- The company's provisions for signatories (the joint Board of Directors can always bind the company legally by their signatures)

- The share capital (at least DKK 500,000 (EUR 67,050) for a public limited company (A/S), and at least DKK 125,000 (EUR 16,762) for a private limited company (ApS)).

867. According to the DCCA for S.M.B.A., F.M.B.A and an A.M.B.A. the information described above and subsequent changes are registered at the Danish Commerce and Companies Agency and available to the public in the same way as $\mathrm{A} / \mathrm{S}$ and $\mathrm{ApS}$ information.

868. A K/S and an I/S only have to be registered when all general partners/ partners are undertakings with limited liability. The information registered is the name and registration number of the general partner/ partners, the name of the $\mathrm{K} / \mathrm{S} / \mathrm{I} / \mathrm{S}$, its address, its objects, accounting period, name and full address of all members of the board of management and a possible board of directors, who has the right to sign for the company. The information and subsequent changes are registered at the Danish Commerce and Companies Agency and available to the public in the same way as $\mathrm{A} / \mathrm{S}$ and $\mathrm{ApS}$ information.

869. A commercial foundation must register its articles of association and information on members of the board of management and directors, the auditor act. This is registered at the Danish Commerce and Companies Agency and available to the public in the same way as $\mathrm{A} / \mathrm{S}$ and ApS information.

870. An EEIG is registered in a central register at the Danish Commerce and Companies Agency. Registrations are published in the Danish Official Gazette (Statstidende).

871. In the case of $\mathrm{A} / \mathrm{S}$ and $\mathrm{ApS}$ no information regarding the beneficial owner of the company is subject to registration in the CVR and therefore accessible to identify beneficial owner. With the exception of bearer shares holders the names of the holders of registered shares are indicated in the registry of shares. It appears that 
the names of $\mathrm{A} / \mathrm{S}, \mathrm{ApS}$ and $\mathrm{K} / \mathrm{S}$ owners are not required to be registered in the CVR.

872. Off the shelf companies are available and usually offered by lawyers; now that registration of company has been made free of charge (and available on line too) the authorities expect this phenomenon to diminish considerably.

\section{$\underline{\text { Bearer shares }}$}

873. As already mentioned, the Danish Public Company Act provide for the possibility to issue bearer shares, up to the whole capital of the company. The Act also requires companies to keep a register of registered shares, which however is not subject to registration of the name of the holders of bearer shares. This can only be known in the circumstances in which the law provides for notice requirements to the company, and subsequent registration in a separate register (accessible to DCCA and to the public in form of transcripts), namely when voting rights of shares represent five per cent or more of the voting rights or the nominal value of the shares represents five per cent or more of the share capital and amounts to not less than DKK 100,000 (EUR 13,410). Notice must also be given if any changes occur to an ownership interest already reported to the effect that the level of ownership in the range of between 10 per cent and 100 per cent, in five percentage point intervals, and levels of one-third or two-thirds of the voting rights or nominal value of the share capital, respectively, rise above or fall below such intervals. Finally, notice must be given if changes occur to the effect that the level of ownership falls below five per cent or more of the voting rights or the nominal value of the shares represents five per cent or more of the share capital and amounts to not less than DKK 100,000 (EUR 13,410). The DCCA does not have statistics on the extent of use of bearer shares, but they believe their use is not widespread and largely limited to listed companies.

\section{Foreign branches/subsidiaries}

874. Foreign companies may operate in Denmark either with a representative office or with a branch office. In the first case there are no registration requirements, however the number of activities which the representative office can carry out are extremely limited (no commercial activities and no possibility to issue invoices). The branch office can be established in Denmark if the parent company is registered in the EU, Switzerland, Norway, Iceland and the USA. If the parent company is not registered in any of these countries, the parent company must send a statement of reciprocity along with the registration form. There is an obligation to register in the CVR if the foreign companies are obliged to pay taxes in Denmark or if they have employees in Denmark. If a branch office is set up, the following information about the parent company is required:

- Names and addresses of the persons authorized to sign for the branch

- Name and address of the manager of the branch, including CPR number

- Basic information about the parent company

- $\quad$ Provisions regulating the power to bind the parent company

- Provisions regulating the power to bind the branch office

- Object of the parent company

- Object of the branch office

875. In the case of foreign companies there appears to be no obligation to disclose information about parent company.

876. Controls performed by the DCCA are formal on the completeness of the documentation presented for registration; however the evaluators were informed that in the case DCCA suspects that the documents provided are false it would usually file a request to the competent authority of the foreign jurisdiction.

877. The DACBR and the Order no. 977 of $17^{\text {th }}$ of October 2005 are not applicable in Greenland and in the Faroe Island. The Danish legislation on $\mathrm{A} / \mathrm{S}, \mathrm{ApS}$ and commercial foundations are applicable also in Greenland 
and the Faroe Islands.

\section{Recommendations and comments}

878. The information on beneficial ownership of legal persons should be more accurate and up to date, especially in the case of foreign legal persons.

879. Authorities should evaluate if the issuing of bearer shares pose a risk of ML/TF in the case where no information is available on beneficial ownership.

\section{Compliance with FATF Recommendations

\begin{tabular}{|c|c|c|}
\hline & Rating & Summary of factors underlying rating \\
\hline R.33 & $\mathrm{PC}$ & $\begin{array}{l}\text { - While the authorities rely on law enforcement and inspection powers to } \\
\text { get information about beneficial owner of companies, this information is } \\
\text { available in a limited form (only for } \mathrm{A} / \mathrm{S} \text { and } \mathrm{ApS} \text {, in certain } \\
\text { circumstances) and it is not up to date. } \\
\text { - In the case of foreign companies no information about beneficial owner is } \\
\text { available. } \\
\text { - In the case of bearer shares, information on the beneficial owner is limited } \\
\text { only to the shareholders holding shares above a designated threshold. } \\
\text { Legislation is not fully applicable in Greenland and Faroe Islands. }\end{array}$ \\
\hline
\end{tabular} \\ 5.2 Legal Arrangements-Access to beneficial ownership and control information (R.34)}

\section{Description and analysis}

880. It is not possible to establish a trust according to Danish legislation, and, therefore, there are no domestic trusts operating in Denmark. The MLA, however, in the definition of "providers of services for undertakings" indicates among the activities that would qualify under this definition also the case of a person "acting as or arranging for another person to act as a trustee or administrator of a fund or another similar legal arrangements".

The evaluators have been informed about bank account holders that are foreign trustees, even though it was not possible to ascertain how wide the phenomenon is.

881. Moreover it was learned that, a trust can operate in Denmark and register itself as branch/subsidiary of a foreign institution. In this circumstance the information requested for registration is the one described in the previous section in the case of foreign branches. Therefore "basic" information required about the "parent company" in the case of branch/subsidiary of a foreign company should be provided also in the case of the trust. In the absence of a clear indication about the type of information required, it is not clear, however, how this information would be sufficient to ascertain the beneficial ownership. It would be advisable to indicate precisely the information requested (for instance on the settlor, the trustees, the protector, if any)

882. According to the authorities, currently there are no foreign trusts registered as branches in Denmark.

\section{Recommendations and comments}

883. Measures should be taken to ensure transparency of foreign trusts and to get access to adequate, accurate and timely information on beneficial ownership. 


\begin{tabular}{|l|l|l|}
\hline \multicolumn{2}{|c|}{ Compliance with FATF Recommendations } \\
\hline R.34 & PC & $\begin{array}{l}\text { Summary of factors underlying rating } \\
\text { Although the authorities indicate that there are no trusts registered in } \\
\text { Denmark, the information which would be subject to disclosure in the } \\
\text { case of a trust operating as a foreign branch does not appear to be } \\
\text { sufficient. }\end{array}$ \\
\hline
\end{tabular}

\subsection{Non-profit organizations (SR VIII)}

\section{Description and analysis}

884. [Assessor's note: The site visit to Denmark occurred after the FATF had adopted the Interpretive Note to SR VIII, but before that Note had been translated into specific criteria in a revised Methodology. In order to maintain the principle that each jurisdiction should be evaluated in accordance with the standard in place at the time, but without presuming on the work of the Working Group that will develop the methodology, the mission adopted the following approach:

- Base the evaluation on the 3 Essential Criteria from the current methodology.

- Wherever the Essential Criteria made reference to "measures in place," evaluate the adequacy of measures in the three domestic areas identified in the Interpretive note (i.e., outreach, supervision or monitoring, investigation and information gathering) using the requirements set out in the Note.

- Evaluate mechanisms for international cooperation, taking into account the evaluation in SR V. ]

\section{General issues:}

885. There is no current obligation to register for either Danish Non-Profit foundations or for associations. Danish Non-Profit foundations can notify the Civil Affairs Agency, supplying the articles of the foundations, list of the board of directors, including names and addresses. Danish associations are formed by contract of their members and do not have to register with the authorities at all. To obtain a bank account in its own name, a Danish NPO must register for a CVR number, and over 66,000 NPOs have done so. Such a registration requires basic address and identification information, but no financial reporting.

886. Danish NPOs that wish to conduct public collections of funds (e.g., door to door, on the street, through mass media, or via collection boxes), must notify the police with information on who will be collecting the funds and the purpose for which the funds will be used. The right to collect door-to-door or on-the-street is further restricted to a list of 30 specified NPOs (not all of which are still active). These collections are meant to support targeted fundraising for specific causes and all funds from such a collection must be placed in a separate bank account and accounts must be published within 6 months in a mass-circulation newspaper in the area in which the collection took place.

887. All Danish NPOs, regardless of legal form, that wish to be exempt from taxation and/or to have the benefit of receiving tax-deductible donations, must file much more extensive paperwork with the tax authorities. The information collected includes:

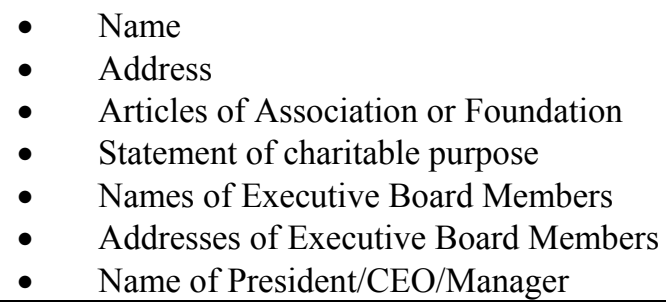




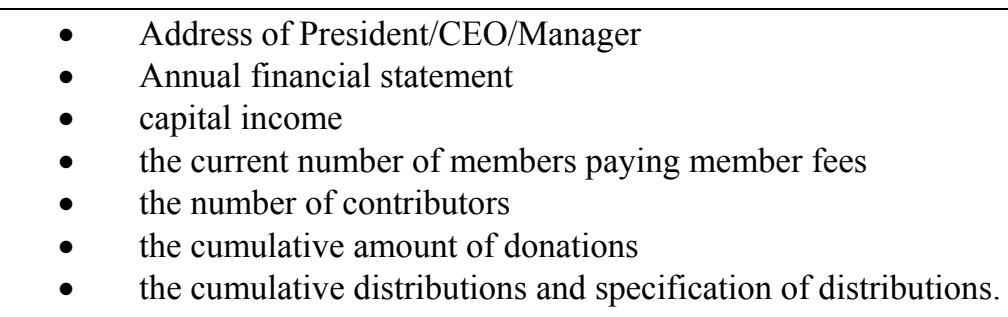

888. 836 organizations, including all ISOBRO members and those active organizations on the list for public contributions, have applied for and received these benefits. This status has to be renewed annual, with the presentation of an annual financial statement. The Danish Tax authorities check the names in their files against the lists of designated terrorists maintained by the EU.

889. The tax authorities have the right to ask for more information in specific circumstances. For example where there are activities abroad, they can request information on projects abroad (objective of the project, the person in charge of the project, budget framework, names of the receivers of the funds, etc.).

890. There is a more limited reporting requirement for religious communities, who have only to report on the cumulative amount of contributions and how they were used.

891. Some 17,000 foundations are further required to file annual tax returns, in which it should stipulate that the majority of its resources are applied to charitable activities, which are defined as Humanitarian purposes (i.e. relief of human distress) or research (scientific study and scrutiny) or protection of nature environment (i.e. abatement of pollution of water, air and soil, including protection of endangered animal and plant species).

892. The Danish Non-profit umbrella organization ISOBRO [see above] requires its members to abide by a more rigorous code of conduct. These rules are enforced by a 3-person council, which can issue warnings and cancel membership.

893. Finally, many Danish NPOs receive money from the state authorities, either from lottery revenues, general grants, or program-specific grants or contracts. These funds are subject to extensive audit, including checks on whether the funds were expended in accordance with the contract. However - with the exception of those general grants that provide budget support for organizations - it is not the current Danish government practice to conduct a general examination of an organization's finances before offering a grant to an organization for domestic expenditure, relying instead on post-program evaluations to determine subsequent grant-worthiness. However, the Danish Aid Agency (DANIDA) does review the annual accounts of Danish NPOs before issuing grants for international work.

\section{Specific analysis of criteria}

894. The authorities' responses to the assessment questionnaire refers to "ongoing consideration" of whether Danish mechanisms for combating the abuse of NPOs need strengthening (1.5.b.4.4, p. 61), with specific consideration concerning the adequacy of current registration mechanisms. The authorities further state that they found no need for changing the Danish system.

895. While the authorities do appear to have given the issues of terrorist financing through NPOs considerable thought, this consideration appears to have taken place informally, rather than in the Steering Group on the Financing of Terrorism, so no explicit record of any review could be provided except for a statement to Parliament, in the context of a [2004] revision of the Criminal Code, to the effect that: "With the adoption of the provisions proposed in this bill together with the amendments of the Money Laundering Act proposed by the Minister of Economics and Business Affairs Denmark is found to fulfill the 8 recommendations 
from FATF."

896. A more formal and structured review of the adequacy of current NPO oversight framework with the direct participation of the wide variety of government authorities that interact with the Danish NPO sector should be undertaken, especially in light of the recent elaboration of the international standard provided by the interpretive note.

897. Many Danish NPOs, whether in the form of association or of foundation, do register with either the tax authorities, the local police, ISOBRO or all three. While these do not constitute a numerical majority of all organizations, this group would clearly appear to represent the largest NPOs and those that are most involved in raising and disbursing funds.

898. The major defense against a terrorist organization posing as a tax-exempt Danish NPO is the documents filed to gain that status. Danish legislation contains no direct protection against a terrorist organization forming itself as an association in Denmark and avoiding government scrutiny by not applying for tax-exempt status or conducting public collections. The Danish authorities have concluded (see above) that the risk of this is not great enough to require all associations to register.

899. The Danish police and security authorities can have access to tax records, including those of NPOs, on the legal basis of Section 28 of the Public Administration Act, which they can and have used in cases where NPOs have come to their attention.

900. There appears to have been little formal outreach to the NPO sector in the context of the formulation of the new MLA law, as they were not subject to any of its provisions, nor specific outreach on the issue of terrorist organizations posing as NPOs.

901. Diversion of funds from a public collection would be very difficult due to the requirements in the law on pubic collections that funds be paid into a collection-specific account and only expended on the announced purpose. ISOBRO members are further subject to the requirement of filing annual audited financial statements. Finally, a limited measure of protection would be provided in the case of foundations by their yearly tax return.

902. These protections, while stronger than those in many jurisdictions due to the control over public collections, do not really address the issue of the end-user. Annual financial statements do not necessarily provide detailed program budgets (although one statement of an ISOBRO member available in English was sufficiently detailed to trace program expenditures at the country level and compare them to the number of claimed beneficiaries). In certain circumstances, for instance, Danish foreign assistance funds being provided through Danish NPOs, significantly more stringent measures are in place. These NPOs are required to sign cooperation contracts with their local disbursing counterparts (who are checked against EU and UN lists), all international transfers must take place through a Danish Bank, and accounts of the local counterparts are audited by internationally recognized audit firms (DANIDA: General guidelines for grant administration). Similarly stringent requirements attach to funds provided for domestic disbursements through the Ministry of Social Affairs.

903. Outreach on the issue of donation diversion has been more extensive. The Danish Security Intelligence Service and the Public Prosecutor for Serious Economic Crime worked with representatives of the NPO sector to produce a document entitled; "Your contribution can be misused," which describes the criminal code provisions concerning the financing of terrorism and explains what people can do to prevent their contributions from being diverted. This brochure has been published in seven languages.

904. The point of contact for international requests for information on NPOs would be the same as those for other TF issues. See (Section 6-4 below). 


\section{Recommendations and Comments}

905. The Danish authorities should undertake a formal review, involving all relevant agencies, of the adequacy of their legal, regulatory, registration, and taxation systems to meet the new international standard as elaborated in new FATF Interpretive Note on SR VIII.

906. The Danish authorities should increase their outreach to the NPO sector to raise awareness of the dangers and indicators of terrorist financing through the NPO sector.

907. The Danish authorities should work with the NPO sector to develop and refine best practices to address TF risks and vulnerabilities and to encourage their widest adoption.

\section{Compliance with FATF Recommendations}

\begin{tabular}{|l|l|ll|} 
& Rating & & Summary of factors underlying rating \\
\hline SR VIII & LC & $\bullet$ & Review of adequacy of legal and regulatory regime only informal. \\
\hline
\end{tabular}

\section{National and International Cooperation}

\subsection{National cooperation and coordination ( $R .31$ \& 32) (criteria 32.1 only)}

\section{Description and analysis}

\section{Recommendation 31}

\section{Overall cooperation and coordination}

908. Under the current system in Denmark, there is no platform for all public institutions involved in AML/CFT, including the FIU, to review policy matters, consider the effectiveness of current AML/CFT initiatives and make changes (or recommend changes) for new policy initiatives or improvements in existing mechanisms.

909. With the passage of the new MLA and the extension of AML/CFT obligations to various sectors, as well as enhanced obligations under the new act for all sectors, it is a particularly good time for there to be regular inter-agency policy level review of current AML/CFT initiatives (including both the preventive and criminal justice aspects), their effectiveness and recommendations for future emphases, approaches or changes.

\section{FIU cooperation}

910. Cooperation and coordination among the different agencies involved in the national anti-money laundering and the financing of terrorism occurs on the basis of formal as well as informal exchanges. The cooperation between agencies and the coordination of their responsibilities takes place at the operational level as well as in the course of official meetings on policy and more general matters.

911. The FIU closely cooperates with the police and the prosecution office. The FIU also regularly cooperates with the police in so far as the receipt and dissemination of STRs.

912. FIU and police cooperation also takes place through the twice yearly meetings of Money Laundering Steering Committee which was formed in 1993 when the FIU was established. It comprises representatives from the National Commissioner, the Chiefs of Police Association, the Commissioner of the Copenhagen Police and the Office of the Public Prosecution for Serious Economic Crime, including the FIU. See Section 1.6 above. 
913. The FIU also closely cooperates with other agencies such as the Danish Security Intelligence Service under the umbrella of the Steering Group on the Financing of Terrorism to consider matters relating to the financing of terrorism. The FIU also requests and receives information for the evaluation of STRs from the tax and the customs authorities.

914. The FIU and FSA although in informal contact from time to time, do not appear to be engaged in a full collaborative effort to enhance AML/CFT compliance. They do not regularly exchange pertinent information that would support each others efforts, for instance information on problems with the level or quality of STR reporting by various financial sectors or specific institutions, or information that might lead to supervisory authorities to target specific institutions for review or support an outreach effort by both authorities to a specific sector.

915. Closer and more regular coordination of efforts between the FIU and FSA, and the FIU and DCCA including addressing such matters as reporting trends, general insights relating to institutional compliance with reporting and other obligations, would serve to enhance AML/CFT compliance.

916. With respect to financing of terrorism matters, although the FIU and NAEC and FIU and Danish Security Intelligence Service collaborate closely, there appear to be lapses in the coordination between these agencies and supervisory agencies with respect to FT matters for which the FIU has responsibility.

917. Although EU lists were available, financial institutions were not always aware of individual state provided lists. The supervisory agencies are charged with ensuring that the institutions and persons under their supervision are complying with requirements regarding all financing of terrorism matters, and the FIU and such agencies should be involved in a coordinated effort to ensure that all appropriate institutions and persons are receiving individual state provided lists and handling them appropriately.

918. With respect to cooperation with the private sector, the FIU and the FSA are engaged in ongoing cooperation with the banking sector through their participation in meetings of the Banker Association's Money Laundering Group.

\section{Other law enforcement cooperation}

919. On a domestic level, police within the districts cooperate closely with each other on cross-district matters and with SØK on economic crime matters. In addition, there is coordination and cooperation with officials in the National Police Commissioner's office on matters such as using special investigative techniques. Law enforcement officials and prosecutors cooperate in various matters that arise in the investigation and prosecution of criminal cases. See section 2.6 above for additional information on law enforcement cooperation.

\section{Supervisory cooperation}

920. The FSA is an integrated supervisory agency. Therefore, there is no need for formal agreements on how to share information between supervisors of different sectors. The FSA also participated in the Committee on Economic Crime and IT Crime under the MOJ from 1998 to 2004 (several of the proposals were enacted by the Parliament in that period). The FSA participated both as member of the Committee and as member of the working group preparing the report on money laundering for the Committee.

921. The FSA cooperates formally but largely informally with the Public Prosecutor for Serious Economic Crime (including the FIU), the DCCA, the NAEC, the MOJ and the MFA. The FSA is in contact with the FIU and the DCCA at least once a week.

922. The FSA also engaged and consulted with the relevant authorities in connection with the revision of 
the FATF Recommendations, the $3^{\text {rd }}$ European Money Laundering Directive and in the preparation of the new MLA.

923. The FSA is also a member of the Bankers Association's Money Laundering Group consisting of representatives from the Bankers Association, the major banks, the Association of Local Banks, the FIU, the FSA and on an ad hoc basis the NAEC. The Group discusses all questions relating to money laundering (including trends and new cases), freezing procedures and financing of terrorism. The FIU provides general feedback, and information on developments in various international fora is shared.

924. Cooperation between the FSA, DCCA and other competent authorities appears to work reasonably well, albeit mostly on an informal basis. There is a need however, for closer cooperation between supervisors and the FIU such as to allow a greater sharing of information on the quality and frequency of suspicious transaction reporting to assist on-site inspections.

\section{Recommendations and comments}

925. A platform should be established and used for regular inter-agency policy level review of current AML/CFT initiatives (including both the preventive and criminal justice aspects), their effectiveness and recommendations for future emphases, approaches or changes.

926. FIU and FSA/DCCA should regularly exchange pertinent information that would support each others efforts, for instance information on problems with the level or quality of STR reporting by various financial sectors or specific institutions, or information that might lead to supervisory authorities to target specific institutions for review or support an outreach effort by both authorities to a specific sector.

927. The FIU and FSA/DCCA should be involved in a coordinated effort to ensure that all appropriate institutions and persons under their supervision are receiving individual state provided lists and handling them appropriately.

\section{Compliance with FATF Recommendations}

\begin{tabular}{|l|l|ll|}
\hline & \multicolumn{1}{|c|}{ Rating } & \multicolumn{1}{c|}{ Summary of factors underlying rating } \\
\hline R.31 & LC & $\bullet$ & FIU and supervisors are in ad hoc rather than regular contact. \\
& $\bullet$ & $\begin{array}{l}\text { FIU and supervisors efforts regarding FT individual state provided lists } \\
\text { not yet fully coordinated. }\end{array}$ \\
\hline
\end{tabular}

\subsection{The Conventions and UN Special Resolutions (R.35 \& SR.I)}

\section{Description and analysis}

928. Denmark's practice is to ratify a convention only after all provisions that must be implemented are reflected in Danish law.

Vienna Convention.

929. Denmark signed the Vienna Convention on 20 December 1988 and ratified the Convention on 29 December 1991. Denmark has enacted legislation to implement the Convention's provisions as applicable to the FATF Recommendations. The Convention however does not apply to the Faroe Islands or Greenland. 
930. The Palermo Convention was signed on 12 December 2000 and ratified 30 September 2003. Denmark has enacted legislation to implement the Convention's provisions as applicable to the FATF Recommendations. The Convention however does not apply to the Faroe Islands or Greenland.

\section{$\underline{\text { CFT Convention }}$}

931. Denmark ratified the UN Convention for the Suppression of the Financing of Terrorism on August 27, 2002. It has fully implemented the Convention. The Convention however does not apply to the Faroe Islands or Greenland.

\section{$\underline{\text { SR I }}$}

932. Denmark has implemented S/RES/1267(1999) and it successor resolutions. It has implemented UNSCR 1373(2001) in part through an EU regulation but with respect to that implementation, other than its implementation of UN designations/EU lists, it is not prepared to freeze assets of terrorists or terrorist organization that may not be intended for use for terrorist purposes. The Security Council Resolutions are not fully implemented in the case of Greenland and the Faroe Islands.

\section{$\underline{\text { Additional elements }}$}

933. Denmark signed the Convention on Laundering, Search, Seizure and Confiscation of the Proceeds from Crime (1990) on 8 November 1990 and ratified it on 19 November 1996. Denmark has also signed the 2005 Council of Europe Convention on Laundering, Search, Seizure and Confiscation of the Proceeds from Crime and on the Financing of Terrorism.

934. Denmark also ratified the Council of Europe Convention on Extradition and the two additional protocols signed the council of Europe Convention on Extradition on 13 December 1957 and ratified on 13 September 1962 with the additional Convention on Extradition signed on 27 September 1976 and ratified on 13 September 1978.

935. The Council of Europe Convention on Mutual Assistance in Criminal Matters was signed on 20 April 1959 and ratified on 13 September 1962 and the additional protocol was signed on 25 October 1982 and ratified on 7 March 1983.

936. Denmark signed the Council of Europe Convention on the International Validity of Criminal Judgments on 28 May 1970 and ratified it on 28 May 1970, the Council of Europe Convention on the Transfer of Proceedings in Criminal Matters signed on 15 May 1972 and ratified on 13 November 1975, and Council of Europe Convention on the Transfer of Sentenced Persons was signed on 21 March 1983 and ratified on 16 January 1987 and the additional protocol was signed on 18 December 1997 and ratified on 10 September 2001.

\section{Recommendations and comments}

937. Denmark should adopt mechanisms to freeze all assets of terrorists and terrorist organizations not only those that may be used for terrorist purposes.

938. Legal framework and implementation in the Faroe Islands and Greenland for all applicable convention obligations need to be put in place, and conventions extended to these jurisdictions.

\section{Compliance with FATF Recommendations}

\begin{tabular}{|l|l|lc|}
\hline & Rating & \multicolumn{2}{c|}{ Summary of factors underlying rating } \\
\hline R.35 & PC & $\bullet \quad$ Vienna, Palermo and Terrorist Financing Conventions have not been \\
\hline
\end{tabular}




\begin{tabular}{|c|c|c|}
\hline & & extended to the Faroe Islands and Greenland. \\
\hline SR.I & $\mathrm{PC}$ & $\begin{array}{l}\text { - Greenland and the Faroe Islands have not yet fully implemented the } \\
\text { UNSCRs. } \\
\text { - The Terrorist Financing Convention is not applicable in Greenland and the } \\
\text { Faroe Islands. } \\
\text { Denmark has not fully implemented SR } 1373 \text { in that in non-UN list or EU } \\
\text { designation matters, there is a limitation on the assets of a terrorist or } \\
\text { terrorist organization that authorities are prepared to freeze (only assets } \\
\text { intended for use for terrorism purposes). }\end{array}$ \\
\hline
\end{tabular}

\subsection{Mutual Legal Assistance (R.32, 36, 37, 38, SR.V)}

\section{Description and analysis}

939. Denmark is able to provide a wide range of mutual legal assistance in AML/CFT investigations, prosecutions and related proceedings. While it is a party to a number of international agreements for the provision of mutual legal assistance and may base the provision of assistance on such agreements, Denmark is also able to, and does, provide assistance in the absence of an agreement. It applies the principles of the European Convention on Mutual Assistance in Criminal Matters when the request is from a country with which there is no agreement. Reciprocity is not a requirement.

940. Dual criminality is required for coercive measures unless a matter falls under special arrangements as with Nordic countries and EU member states. Assistance that does not involve coercion is available regardless of dual criminality. There is a broad approach to dual criminality, and authorities consider whether the same facts would give rise to a criminal offence. Mutual legal assistance is available in fiscal matters and requests are not refused on the ground that the offence also involves a fiscal matter.

941. Denmark does not have specific legislation relating to mutual legal assistance in criminal matters, but can apply all national legislation to assist foreign authorities. There is no need for a bilateral or multilateral agreement. Danish authorities can comply with a request if the investigative measure requested could be carried out in a similar national case. It uses the criminal procedures set forth in its AJA to comply with requests. This is accepted within the Danish legal system even in absence of a specific provision in this regard. Courts have accepted in case law that the AJA can be used for foreign requests. Denmark is a party to the European Convention on Mutual Assistance in Criminal Matters (and its 1978 and 2001 protocols), and the Convention on Mutual Assistance in Criminal Matters between the Member States of the European Union. ${ }^{19}$ It is also a party to several specific mutual legal assistance agreements with Hong Kong, the Nordic States, and the United States. ${ }^{20}$ If the request is from a European or Nordic country, Denmark complies with the request in accordance with the Council of Europe Convention on Mutual Legal Assistance or Denmark's Agreements between the Nordic Countries.

942. Denmark can provide a full range of assistance and does so in the same manner and to the same extent as it can effect such measures in domestic cases. These include the production of and, as necessary, search and seizure for documents or evidence with the provision of documents and evidentiary items to requesting authorities (see, for instance Sections 801 - 805 of the AJA); taking evidence or statements from persons (see sections 750, 174 and 178 of the AJA) and facilitating the voluntary appearance of witnesses for information or testimony; effecting service of judicial documents (see, sections 153-165, AJA); and undertaking actions to identify, restrain or seizure and confiscate laundered assets, ML proceeds, assets used or intended for use to finance terrorism (see Section 2.3 above). 
943. The powers of Danish authorities to compel production, search persons and premises, and trace, seize and confiscate, records, etc. available under domestic law are fully available in response to mutual legal assistance requests whether the request is made directly by a foreign authority to a Danish court, prosecutor or police official or through MOJ channels. Denmark may also use its wide range of special investigative techniques in support of an request for mutual legal assistance. (See Section 2.6 above relating to investigative techniques).

944. Dual criminality is considered on the basis of the underlying conduct rather than on the basis of specific offences. Denmark may, and has in fact, provided assistance when the offence for which assistance is requested is conspiracy offence under foreign law. Mutual legal assistance is not subject to unduly restrictive conditions. Requests are not refused based upon laws that impose secrecy or confidentiality, as secrecy and confidentially requirements can and routinely are lifted just as they are in domestic matters. Reasons for refusal include that Denmark has instituted proceedings against the person for the same offence, or has decided against proceeding for the same criminal conduct or on ne bis in idem grounds. A refusal may also occur because a request relates to conduct which has been time-barred under Danish law. In the case of EU requests, some matters that would otherwise be time-barred are eligible for assistance under provisions in Denmark's Law on Enforcement of Certain Criminal Decisions in the European Union that went into effect January 1, 2005.

945. Time bar issues under Danish law caused Denmark to refuse assistance in a few instances (for instance in one matter that involved antiquities). The limitations periods in Denmark are 2 years for offences for which the maximum penalty is up to one year imprisonment, 5 years in the case of offences with a maximum of one to 4 years, and 10 years for offences with a maximum between 4 and 10 years. There are only rare conditions placed on use of evidence (for instance, that a statement taken when a person is appearing as a witness may not be used against the person if indicted) and Denmark does not routinely impose the condition that the evidence and materials may be used only for the proceeding for which requested. No other restrictions are placed on the evidence unless necessary as in the instance above to protect human rights.

\section{Procedures for mutual legal assistance}

946. Requests, particularly those from non-EU treaty partners and jurisdictions with which there is no mutual legal assistance treaty, are made to the central authority which is the Office of International Affairs of the MOJ. Its staff of 15 including 8 lawyers handle mutual legal assistance and extradition requests as well as EU police and penalty matters (negotiations of positions, etc.).

947. The Central Authority receives in the range of 500 to 600 requests a year. It has issued a 25 page handbook available on the national legal information database website and also separately distributed to the 52 police districts. It provides advice on how to handle incoming and prepare outgoing mutual legal assistance requests. For incoming requests, among other things, it identifies circumstances in which consultation with the MOJ is appropriate. When incoming requests are received, the Central Authority makes an initial review for completeness and dual criminality (if applicable because the request involves coercive measures) and then forwards the request to the appropriate police district for execution, or in the case of requests that would be appropriate for execution by SØK (including requests relating to the financing of terrorism), to that office. It acknowledges to the foreign authority the receipt of a request and in some circumstances may request additional information from the foreign authority, following up on that request in about 4 weeks if no response is received.

948. Among Nordic countries, and generally for EU countries, there is direct cooperation between judicial authorities and incoming requests are sent directly to prosecutors and police. Outgoing cooperation in such circumstances is also generally provided without the intervention of the Office of International Affairs. If police or prosecutors executing a request encounter difficulties in executing a request (whether the request was forwarded by the MOJ or was a direct request) or determine that execution will be protracted (for instance because of an appeal), they consult with the MOJ. Authorities indicate that in recent years, only in the few cases where there was a clear absence of dual criminality (and a coercive measures requested) or where there was no 
confirmation a case was criminal in nature was assistance declined.

949. In the case of the financing of terrorism requests both incoming and outgoing, there do not appear to be specific arrangements that ensure that all such requests are centralized through SØK. Although the MOJ funnels all such incoming requests to SØK, outgoing requests from Danish prosecutors and police as well as incoming requests that go directly to police districts may not be handled on a centralized basis. An Executive Order, Order No. 1146 of 13 December 2002 does make SØK responsible on a nationwide basis for prosecuting major financial crimes. Given this order, which however is not specific to the financing of terrorism, local police districts must consider whether a financing of terrorism matter in development or a financing of terrorism related request should be handled by SØK. This may assist in ensuring centralized handling of such cases. Nonetheless, even with good informal consultation and the general order, there should be greater clarity and instruction on how to handle such requests that come in from and go out through various channels. The SØK on its part considers that any incoming requests are to be dealt with by the FIU within the SØK in consultation with the Danish National Intelligence Agency which is always immediately informed.

\section{Effectiveness of mutual legal assistance.}

950. Assistance provided by Denmark to other jurisdictions appears to be provided in a timely, constructive and effective manner. Danish authorities indicate they make assistance to other countries a priority and seldom refuse requests. Urgent incoming requests are executed to the extent possible immediately. Most requests are for information, statements from witnesses or tracing and securing of evidence. Delays occur if a request is not sufficiently precise and a clarification must be sought, or if the matter is complex.

951. FATF member countries reported no issues with the provision of assistance by Denmark, ${ }^{21}$ and authorities undertake to ensure such matters as clarification of requests, poor translations, inadequate information and other matters that might result in delays are addressed on an immediate basis. Every effort is made to ensure evidence, records, witnesses, etc. are provided to requesting authorities in a timely manner.

952. Danish authorities cooperate with foreign authorities to consider the best venue for prosecution, in accordance with the Danish Act on Transfer of Proceedings in Criminal Cases. MOJ guidelines of December 5, 2001 to inform prosecutors and the police how to deal with requests for transfers of proceedings.

Mutual Legal Assistance Requests to Trace, Seize, Freeze or Confiscate

953. As noted in Section 1.3 on confiscation, freezing and seizing proceeds of crime, Denmark has adequate laws and procedures to identify, seize and confiscate proceeds, instrumentalities used in or intended for use in and laundered property from any offence, as well as property of corresponding value. These laws may be employed fully in response to a foreign request and may be used to the same extent as in a domestic case. Thus, for instance, assuming dual criminality is met, Danish courts can order a provisional measure of seizure at the request of the foreign jurisdiction both of the property of a person under investigation or charged elsewhere, or that of a third party if it could do so in a similar domestic investigation using the provisions of the AJA by analogy. Denmark does not require a foreign court decision that property or assets be seized if a foreign authority is authorized to require the assistance without a court decision. The seizure may be directed to proceeds or to equivalent property. Requests for freeze are dealt with as quickly as possible, and upon receipt of a request, there is an assessment regarding urgency. Foreign authorities may be aided in the tracing funds and the location of assets through orders issued to the Danish Banking Association which seeks information from its members on the existence of accounts.

954. Requests for provisional measures of a coercive nature from a country for which there is no applicable international agreement are dealt with according to the principles of Council of Europe Convention on Mutual Assistance in Criminal Matters and the Strasbourg Convention. Such requests are handled generally in the same manner as other requests. Once the authorities have concluded dual criminality is met, a Danish 
prosecutor makes the request to a Danish court and the matter is handled using the AJA provisions by analogy.

955. Denmark has implemented the EU Council Framework Decision of 22 July 2003 on the execution in the EU of order freezing property or evidence (as well as other Framework Decisions) through a law that went into effect on January 1, 2005, Denmark's Law on the Enforcement of Certain Criminal Decisions in the European Union. The decision and implementing legislation in Denmark ensures mutual recognition within the EU including Denmark of temporary measures as freezing and seizure. For a wide range of offences, including money laundering, fraud, corruption, and drug trafficking, if punishable by a maximum penalty of three years, dual criminality need not be verified. Under the legislation freezing orders from an EU country may be forwarded with a certificate and the order is recognized and executed without any further formalities. Such an order may be transmitted by an issuing EU judicial authority directly to a competent judicial authority in Denmark. There are limited grounds for non-recognition or non-execution. Under the EU Framework Decision and implementing legislation, interested parties, including bona fide third parties, must have legal remedies to preserve their legitimate interests either in the issuing or executing state, but challenges to the substantive reasons for the issuance of the order must be made in the issuing State.

956. For outgoing Danish requests that involve matters that in Denmark would require a court order such as an order to produce documents or the seizure or restraint of assets, there must be a prior order from the court in Denmark. This stems from the requirement that both incoming and outgoing requests are subject fully to the applicable provisions of Danish law.

\section{Enforcement of Foreign Confiscation Orders.}

957. Denmark is able to recognize criminal confiscation orders based upon its Act on International Enforcement of Criminal Judgments. The Act incorporates into Danish law the 1970 European Convention on the International Validity of Criminal Judgments, and relevant provisions of the Strasbourg and Vienna Conventions. Under the Act, judgments covered by the Validity Convention (section 4) and Vienna Convention (section 5) can be enforced if convention requisites are met. Article 9 of the Act permits the Minister of Justice, based upon a bilateral agreement, to enforce a foreign decision on confiscation from a state not a party to the Validity of Criminal Judgments Convention to the same extent as it would enforce that of a state that is a party to the Convention. There may be individual case specific bilateral agreements. In addition, under section 10, the Minister of Justice may decide to enforce a foreign confiscation order (or any other penalty or other legal consequence imposed) even in the absence of a bilateral agreement when humanitarian or other particular indications call for enforcement.

958. Denmark receives just a few such requests each year, generally in the range of two or three. All confiscation order enforcement matters are overseen and coordinated through the Office of International Affairs of the MOJ, and the arrangements for many requests through which prosecutors may make direct requests to foreign courts and judicial authorities do not apply.

959. As a rule the enforcement of a foreign confiscation order, whether the request is based upon the Vienna, Strasbourg or Validity Convention or a request granted in the discretion of the Minister of Justice, takes place in accordance with the procedure and the conditions laid down in the Validity Convention, Part II, Section 5. Dual criminality must be met and the foreign order forwarded must be final. The Minister of Justice makes the initial decision to enforce the order. The Minister's decision is forwarded to a prosecutor who presents the decision to the court which then determines if the decision of the Minister is in accordance with the Act on International Enforcement of Criminal Judgments. The court is issuing its order enforcing a judgment is transferring the order into a Danish national sentence. The facts underlying the confiscation are not subject to review. Rules on third party challenge are the same would apply in a Danish case. A third party must establish he/she has a legal interest and a substantive challenge must be made in the courts of the jurisdiction from which the request emanated. 
960. There have been only a few cases in the last two years. Denmark enforced final confiscation orders in two cases transferring DKK 16 million (EUR 2,1 million) in one case and 2 million German marks in a second case.

Arrangements for co-coordinating seizure and confiscation actions

961. Danish authorities coordinate both seizures and confiscations on a case by case basis as needed with the appropriate foreign authority using mechanisms such as direct contact, Europol or other communication channels. In the case of seizures, they will confer to with all appropriate authorities to ensure that all related seizures will take place at the same time. A support team is appointed in each matter where it is needed that is assigned communication responsibility. In the case of Danish investigations where a request for seizure is being executed in another jurisdiction, typically Danish investigators will participate in seizure. Likewise foreign investigators may participate in the execution of a seizure in Denmark in a seizure is taking place at foreign request. The NPC's Serious and Organized Crime Agency coordinates such cross-border seizure matters. Confiscation will also be coordinated as necessary through direct contacts between Danish and foreign prosecutors or central authorities for mutual legal assistance, but there have not arisen confiscation matters where such action was necessary.

\section{Asset Forfeiture Fund and Sharing of Assets}

962. With the advent of the FATF 40 and other international efforts relating to confiscation and forfeiture, Denmark has had occasion to consider through the years whether to establish a separate asset forfeiture fund. The decision to date has been not to establish such a fund but to continue to have domestic law enforcement expenses covered based on decisions by the Parliament, and adhere to the long standing practice that receipts to the State from whatever source are placed in the Treasury. Domestic criminal fines as all other receipts are placed in the Treasury.

963. Although Denmark does not have a general system that permits the sharing of assets, in fact, on a case specific basis, it can and has shared proceeds. The general rule (consistent with Article 47 of the Council of Europe Convention on the International Validity of Criminal Judgments rule that proceeds should be paid into the requested State's treasury subject to third party rights) is that the proceeds of confiscation are deposited into the Danish Treasury. Transfers of sums confiscated can take place in an individual case based upon the Vienna or Strasbourg Conventions if there is reciprocity. This may occur for instance if there is a claim for damages from the violation that formed the basis for confiscation, or if the crime, apart from the proceeds confiscated, did not have a connection with Denmark. The Danish Minister of Justice has transferred proceeds to other jurisdictions in several cases.

964. Denmark's Law on Enforcement of Certain Criminal Decisions in the European Union which went into effect on January 1, 2005 and implements recent EU Framework Decisions (including the Framework Decision on the application of mutual recognition to confiscation orders) provides inter alia for the sharing with EU member states in some instances. Under Section 42 of the Law, which addresses confiscation of money, amounts less than 10,000 EUR fall to the Danish Treasury but amounts in excess of the 10,000 EUR threshold are shared equally. Under Section 43 of the Law which addresses assets other than money, the confiscated assets can be sold and the resulting revenue shared in the same way as with confiscated money, or it can be transferred to the requesting country or, if neither is possible, it reverts to the Danish Treasury.

\section{$\underline{\text { Statistics. }}$}

965. Statistics on the number of incoming and outgoing mutual legal assistance and extradition requests for ML and the predicate offences, and the time periods for execution have not been maintained in the past, but MOJ officials have indicated they were aware of the need to begin maintaining and evaluating such statistics. Officials provided a rough estimate of approximately 500 to 600 annual incoming requests and 400 outgoing requests through the Office of International Affairs, MOJ. In addition, there are unknown numbers of requests 
that are sent directly to and from prosecutors and law enforcement personnel. When police districts receive an incoming request unrelated to an open Danish matter that has already been registered, the request is given an independent inquiry reference number in the registry maintained in the district, but this registry also includes inquiries unrelated to international legal assistance.

966. Statistics gathering and evaluation should be ongoing and the program adopted should address both requests that are sent and received directly by executing authorities as well as those that go through the MOJ channels.

\section{$\underline{\text { FT Statistics }}$}

967. Authorities, through the Steering Committee on the Financing of Terrorism, maintain statistics on FTrelated international requests although it is not clear that there are procedures in place to ensure that such statistics reflect all such matters since in the Danish system there may be direct mutual legal assistance requests to executing authorities. The MOJ's Office of International Affairs forwards all requests it receives to the Steering Committee, and the Committee receives such requests as well both directly and from the MFA. In addition, the statistics do not differentiate foreign requests for assistance (mutual legal assistance requests in an ongoing case or matter) from STRs from banks based upon the provision of a name by a foreign authority or through the EU process. The statistics are maintained on what appears to be an informal basis through an understanding that all such matters should be referred to the Steering Committee on the Financing of Terrorism. Danish authorities indicated that most of the inquiries it received were general requests regarding whether they were aware of persons or organizations on a list provided. Danish authorities indicate that there have only been a few case related requests relating to FT, including one in which there was both an incoming and outgoing request. In no case has a request been refused, but in one case the parties agreed to postpone a response from Denmark because a Danish investigation was also pending.

\section{$\underline{\text { Additional Element }}$}

968. The powers of competent authorities to compel production, search and seize are available when there is a direct request to counterparts in Denmark from jurisdictions that are a party to the European Convention on Mutual Legal Assistance, and in practice, those same principles are applied to countries not a party to the Convention.

Greenland and Faroe Islands

969. The European Convention on Mutual Assistance in Criminal Matter (and its 1978 and 2001 protocols) are applicable to Greenland and the Faroe Islands, and Danish authorities indicate these jurisdictions are able to provide (and request) mutual legal assistance in the case of parties to the Convention. The Danish MOJ acts as a central authority for these jurisdictions with both incoming and outgoing requests handled by the Ministry for the rare requests involved. Since there are some limitations on the criminalization of ML and FT in these jurisdictions (see Sections 2.1 and 2.2 above), there may be barriers to providing assistance that requires coercive measures since there would be in some circumstances an absence of dual criminality. In addition, there are no treaties or other provisions for assistance to non-parties to the Convention although for in the case of measures that do not require coercion, the principles of the European Convention would be applied and assistance provided.

\section{$\underline{\text { Summary and Effectiveness }}$}

970. Denmark has an exemplary mutual legal assistance framework with an ability to provide assistance based upon a series of international instruments as well as a full ability to provide assistance to any requesting state regardless of a treaty. In addition, it has made all domestic provisions available to execute requests and uses them liberally to assist other States. This, combined with a setting where there are few limitations regarding when assistance is provided (other than dual criminality) or on the use of the actual evidence forwarded, with a multi-channel system which includes direct requests (which are quicker), and with its authorities' commitment to provide the fullest range of assistance possible in a timely and open fashion, makes the system an excellent one. 
In addition there is a system for direct recognition of foreign confiscation orders. A number of FATF countries that responded to the request for information on their experience with Denmark's mutual legal assistance program indicated that Denmark has provided timely assistance; others indicated there was no relevant experience.

971. Mutual legal assistance is thus freely available and Denmark is committed to providing it in an effective manner. However, there are a few barriers of note that may occasionally arise. Although the use by analogy of domestic law has many positive effects, there are a few circumstances in which it may place a limitation on assistance, notably in situations when because of a Danish limitations or time bar, Denmark is not able to provide assistance although the underlying conduct is still actionable in the requesting State. In the case of EU countries making a request that might otherwise be time-barred, this has recently been altered to some degree with Denmark's enactment of the law implementing recent EU directives. Denmark should consider altering the use of the time bar in the case as well of other States, so that a country proceeding with a case still viable in its own jurisdiction is not denied assistance.

972. The second limitation also relates to the application in the mutual legal assistance setting of domestic law is the requirement that Danish prosecutors secure a Danish court order for production of documents or provisional measures such as seizure (freezing or seizing) prior to making a request to another State to take such action on its behalf. Authorities indicate that securing such orders can occur quickly and that, in urgent cases, the police may make the decision regarding the seizure with the matter brought to the court later if the affected party so requires. In fact, the latter procedure has been used in several cases. Nonetheless seeking such requests adds an additional step and poses a small but not insurmountable barrier particularly where there are fast moving proceeds or account records are needed immediately.

973. Although freely available in Denmark, there are some limitations on provisions of assistance in the case of Greenland and the Faroe Islands as noted above.

\section{Recommendations and comments}

974. Denmark has not maintained the statistics necessary for it to fully evaluate its mutual legal assistance program. Statistics gathering and evaluation should be ongoing, and the program adopted should address both requests sent and received directly by executing authorities as well as those sent and received through the MOJ channels.

975. Although Greenland and the Faroe Islands are able to request and provide mutual legal assistance generally to parties to the European Convention and under the principles of the Convention to other states if a coercive measure is not involved, the narrower scope of the ML and FT criminal provisions in Greenland and the Faroe Islands (see Sections 2.1 and 2.2 above) may form an obstacle to providing assistance involving coercive measures because of an absence of dual criminality. In addition, tracing, seizing and freezing and confiscation provisions should be updated as is occurring so a full measure of assistance can be provided.

976. Arrangements for incoming and outgoing requests relating to FT should be enhanced to ensure all requests, including direct requests (those issued directly from or to prosecutors/police authorities), are channeled through SØK with the FIU is involved and informed.

977. Denmark should consider providing mutual legal assistance when the underlying conduct is still actionable in the requesting state but time-barred within Denmark, and review whether it is possible to lift the requirement of a Danish court order for production of documents or provisional measures such as seizure (freezing or seizing) prior to making an international request, particularly in the context of fast moving proceeds or account records needed on an immediate basis.

Compliance with FATF Recommendations 


\begin{tabular}{|c|c|c|}
\hline & Rating & Summary of factors relevant to section 6.3 underlying overall rating \\
\hline $\mathbf{R . 3 6}$ & $\mathrm{LC}$ & $\begin{array}{l}\text { - Greenland and the Faroe Islands are not be able to provide assistance in } \\
\text { some ML and FT matters given the narrower scope of the AML/CFT } \\
\text { provisions. Nor is assistance involving coercion available in the case of } \\
\text { states not a party to the European Convention. }\end{array}$ \\
\hline $\mathbf{R . 3 7}$ & $\mathrm{C}$ & \\
\hline $\mathbf{R . 3 8}$ & $\mathrm{LC}$ & $\begin{array}{l}\text { Denmark fully complies but Greenland and the Faroe Islands may not } \\
\text { always be able expeditiously to freeze and seize in ML matters both } \\
\text { because of dual criminality issues and because provisions need updating. }\end{array}$ \\
\hline SR.V & $\mathrm{LC}$ & $\begin{array}{l}\text { - }[\mathrm{LC} \text { for this section.] Denmark fully complies but Greenland and the } \\
\text { Faroe Islands may not be able to provide mutual legal assistance for all } \\
\text { requests that relate to the financing of terrorism. }\end{array}$ \\
\hline
\end{tabular}

\subsection{Extradition (R.32, 37 \& 39, \& SR.V)}

\section{Description and analysis}

978. In Denmark, both ML and FT are extraditable offences. There have been no extradition requests in the case of ML or FT. Extradition is governed by the Consolidated Act of August 25, 2005, No. 833 on Extradition of Criminals ("Extradition Act"). Pursuant to section 3 of the Extradition Act, extradition can only take place if, under Danish law, the alleged crime upon which the requested extradition is based entails a penalty of imprisonment for more than one year (in cases of extradition to an EU member State at least one year unless the offence is on the positive list). This requirement is satisfied in ML and FT cases. Section 2 of the Extradition Act lays down general conditions for the extradition of Danish nationals. Nationals may be extradited if they have resided elsewhere and other conditions apply, and in addition there are provisions for transfers of proceedings such that Danish nationals may be prosecuted in Denmark for conduct that occurred in the country seeking the extradition.

979. Extradition is not conditional upon the existence of a treaty. Extradition is therefore possible even in the absence of an agreement on extradition between Denmark and the requesting country. The offence for which extradition is requested need not be the same as long as the underlying conduct is covered by a criminal law provision in both Denmark and the requesting country. Dual criminality is a condition for extradition to nonNordic countries, but does not apply in the case of Nordic countries.

980. Principles that apply for extradition differ somewhat depending upon whether extradition is with an EU country, a Nordic country, a country with which there is an extradition treaty (as is the case with the United States and $\mathrm{Canada}^{22}$ ), or with a non-EU country with which there is no extradition treaty.

981. For countries that are signatories to the European Convention on Extradition, extradition is based on that convention, its two additional protocols. ${ }^{23}$ More recently, extradition to and from Denmark for Member States of the European Union is replaced by the procedures mandated by the Council Framework decision on the European arrest warrant and the surrender (entry into force in Denmark January, 2004). For Nordic countries, extradition is based on the Danish law on extradition to the Nordic countries of 3 February 1960. For countries with whom Denmark has a treaty relationship, there is a requirement to extradite (or in some instances to act on the basis of a transfer of proceedings) pursuant to the terms of the treaty. In other instances, the decision to extradite is within the discretion of the Minister of Justice.

European Union countries 
982. Within the EU, surrender pursuant to the European arrest warrant in large part replaces a formal extradition. The Extradition Act specifies that extradition from Denmark to other EU Member States may occur based upon a European arrest warrant. Such extraditions differ from others in that:

- $\quad$ For many offences, dual criminality is not required. These include ML and terrorism (including TF) as well as many other offences such as drug trafficking and fraud offences (listed in section 10a of the Extradition Act).

- Danish nationals are extraditable in the same way as foreign nationals.

- Extradition may not be refused on the grounds that the offences involved are political or that there is insufficient evidence to support the charge or conviction for an act for which extradition is sought.

- The issuance of the European arrest warrant in itself provides the basis upon which to secure the arrest and extradition.

983. A request pursuant to a European arrest warrant must be dealt with within specified short time frames. As a general rule, the decision of the Minister of Justice must take place within 10 days, and the court's decision should issue within 60 days.

$\underline{\text { Nordic countries }}$

984. Act No. 27 of 3 February 1960 on the Extradition of Offenders to Finland, Iceland, Norway and Sweden, as amended by the Nordic Extradition Act of 1975, permits the extradition of a Danish national to these countries if the criminal act has a penalty of imprisonment for more than four years or if in the two years prior to the criminal act the person resided in the Nordic state that seeks the extradition. As noted, dual criminality is not required for extradition to a Nordic state.

\section{Non-European Union countries}

985. Extradition of a non-Danish national to a country outside the EU may take place if the underlying acts are punishable under Danish law by imprisonment of one year or more. Accordingly, extradition is available both in the case of ML and TF. If the extradition is to enforce a judgment, generally the person must have been sentenced to at least four months imprisonment in the requesting country. Provisions of extradition treaties with Canada and the United States make extradition a requirement if the treaty terms are met.

986. Danish nationals may also be extradited to non-EU countries in certain circumstances. They are subject to extradition if they have resided in the requesting country in the two years prior to the commission of the criminal act, and the act corresponding to the Danish criminal offence is punishable with imprisonment for at least one year or could be punished under Danish law by a penalty in excess of 4 years imprisonment. This permits prosecution of Danish nationals that have resided in other states to be handled efficiently. The proceedings are carried out where the offence was committed and evidence need not be produced in Denmark of an offence that was committed elsewhere. Under Section 3(4) of the Danish Act on Extradition, however, nationals may not be extradited if, under special circumstances, the crime for which extradition has been requested is considered to be ill founded.

987. In those cases where extradition is not permitted because a Danish national is involved and the above circumstances do not apply, Danish authorities must consider prosecution in Denmark.

\section{$\underline{\text { Refusal of Extradition and Conditions for Extradition }}$}

988. Extradition may refused if the request relates to a military or political offence (with an exception for political offences that relate to terrorism matters or for political offences where extradition is requested by an EU country), if there is a danger the person would be subject to persecution upon extradition, or it would contravene humanitarian considerations to extradite him/her. It is also not permitted if a person has been acquitted of or 
pardoned for the same criminal act in Denmark or the liability is time-barred under Danish law. (Sections 4-9 Extradition Act.) In addition, when an extradition is granted, the usual conditions are set forth that the person may not without the consent of Denmark be prosecuted or punished in the other state for other offences that were committed prior to the extradition, or re-extradited elsewhere without the consent of Denmark, nor may capital punishment be imposed.

\section{Prosecution of Danish nationals in lieu of extradition and transfers of proceeding}

989. Danish nationals whose extradition is declined because of their nationality may be prosecuted in Denmark. Under section 7 (Chapter 2) of the Criminal Code, an act committed in another State by a Danish national or resident is subject to Danish criminal jurisdiction if the underlying act is punishable in both the jurisdiction where the offence took place and in Denmark. There is an obligation to consider such prosecution based upon the occurrence of the underlying conduct if such conduct constitutes an offence under Danish law.

990. The MOJ will forward a case to the prosecutor on an immediate basis and the prosecutor makes decisions regarding the investigation and prosecution The Danish decision regarding whether to prosecute and the conduct of the proceedings in Denmark occur in the same manner as they would with respect to a similar domestically occurring offence. Decisions concerning the punishment and other legal consequences because of the act are made according to Danish law. Under section 10 of the Criminal Code, when a case is based upon an assertion of criminal jurisdiction over a Danish citizen for an act he committed in another jurisdiction, the punishment the offender receives may not be more severe than that provided for under the laws of the state where the act was committed. Nationals and residents of other Nordic countries who are present in Denmark may also be prosecuted through a transfer of proceedings.

991. Transfers of proceedings are made on the basis of the rules in the European Convention on the Transfer of Proceedings in Criminal Matters which was implemented in Danish law in 1975 and in 1986. Although a transfer would normally be possible only to countries that acceded to the convention, under section 5 of the Act on Transfer of Proceedings, the Minister of Justice may decide on the basis of mutuality to apply the act even though a country has not acceded to the Convention.

992. Where a proceeding may occur in either Denmark or another country, decisions on the locus for proceedings are based upon prosecutorial recommendations which reflect convenience and availability of evidence considerations. With the current provisions that permit the extradition of Danish citizens in many instances, there is not a need for transfers of proceedings into Denmark often. However, where Denmark does initiate proceedings against a national based upon conduct occurring elsewhere, it cooperates closely with the jurisdiction where the underlying conduct occurred to secure evidence and on various procedural aspects, and its officials consult by various means including personal visits as needed.

$\underline{\text { Extradition Procedures }}$

993. The Minister of Justice through its Office of International Affairs reviews incoming extradition requests which are always handled on a priority basis. The MOJ conducts and initial screening and unless it is apparent that the extradition must be denied, the request is forwarded to prosecutors for a determination of whether the conditions for extradition have been met. (Section 12, Extradition Act). Procedures and legal measures are the same as those used in similar domestic cases. The affected person is entitled to legal counsel. Once the investigation is concluded, the prosecutor forwards the matter to the Minister of Justice for a decision. This occurs within 10 days when a request from a EU member state is involved and may take from 10 days to several weeks in other matters. If the Minister decides in favor of extradition, the person is entitled to have a court review the legality of the decision or may waive that right. Court review in a simple case may take a week to a month and in more difficult cases if the defendant raises issues and appeals, it may take a more extended time. The extradition must be completed as soon as possible after a final decision. (Sections 13-17, Extradition Act.) Authorities work to ensure, at each step of the procedure, that an extradition moves forward quickly and follow procedures that ensure efficient handling of incoming extradition requests. 
Greenland and Faroe Islands

994. Extradition to and from Greenland and the Faroe Islands in the case of European countries can be based upon the 1957 European Convention on Extradition which applies in these jurisdictions. Other arrangements do not appear to be in place and the extradition provisions of the Vienna, Palermo and Terrorist Financing conventions which would provide a basis for extradition for the offenses covered by those conventions are not available as the conventions have not yet been extended to these jurisdictions. In addition, the limitations on the scope of the ML and FT criminalization may affect dual criminality necessary for extradition.

\section{Statistics}

995. Danish authorities have just begun to maintain regular statistics on extradition requests. During 2005, there were 11 requests for extradition from countries outside the European Union and 43 European arrest warrants received. On outgoing requests, there were 10 requests for extradition from countries outside the European Union and 77 European arrest warrants issued. Information on the nature of the request, whether granted or refused and the time required to respond should also be maintained.

\section{$\underline{\text { Additional elements }}$}

996. While in principle, the direct transmission of an extradition request (to the MOJ rather than submission through diplomatic channels) must be based on an international agreement, in practice the MOJ normally accepts direct requests from any requesting jurisdiction regardless of an agreement.

\section{Recommendations and comments}

997. Denmark should maintain comprehensive statistics on incoming and outgoing extradition requests including the nature of the request, whether granted or refused and time required for response.

998. In the case of Greenland and the Faroe Islands, the European Convention on Extradition applies but there do not appear to be treaties, conventions (as the Vienna, Palermo and Terrorist Financing) or domestic laws and procedures that would permit extradition in the case of other countries. In addition, as the Terrorist Financing Convention does not extend to these jurisdictions and there is not full criminalization of terrorist financing, possibilities for extradition for financing of terrorism-related offences appear limited. Likewise, although ML is criminalized in Greenland and the Faroe Islands, the criminalization does not fully meet international standards and this may pose dual criminality issues in an extradition context. Authorities should put in place the legal and practical framework by extending conventions to these jurisdictions which would provide a legal basis for extradition, ensuring the criminalization provisions meets Convention requirements and putting any domestic provisions in place that are necessary for extradition to occur.

\begin{tabular}{|c|c|c|}
\hline \multicolumn{3}{|c|}{ Compliance with FATF Recommendations } \\
\hline & Rating & Summary of factors relevant to section 6.4 underlying overall rating \\
\hline R.37 & $\mathrm{C}$ & \\
\hline R.39 & $\mathrm{LC}$ & $\begin{array}{l}\text { Denmark is fully compliant, but there are not adequate conventions, laws } \\
\text { and procedures for extradition in the case of Greenland and the Faroe } \\
\text { Islands. }\end{array}$ \\
\hline SR.V & LC & $\begin{array}{l}\text { [PC for this section.] Denmark is fully compliant, but Greenland and the } \\
\text { Faroe Islands do not meet the requirement that they not serve as possible } \\
\text { safe havens because of the limited scope for criminalization of the }\end{array}$ \\
\hline
\end{tabular}




\subsection{Other Forms of International Cooperation (R.32, 40, \& SR.V)}

\section{Description and analysis}

\section{Law enforcement cooperation}

999. Denmark is able to and does cooperate with foreign law enforcement through a number of established channels. Incoming and outgoings police requests are made through established channels as Interpol or Europol. The National Criminal Intelligence Service of the NPC's Serious and Organized Crime Agency serves as the central point for incoming and outgoing police requests. In addition, in cooperation with other Nordic countries, there are 40 police officers stationed in other countries through whom law enforcement cooperation may be facilitated. In addition to Interpol, Europol, Schengen and Nordic Police Cooperation arrangements, there are bilateral arrangements with several countries that are facilitated through embassy or consular officials. Denmark is a party to several conventions allowing for direct exchange of information. Cooperation channels as Interpol, Europol or the Egmont Secure Web are also used. There are no barriers to Danish law enforcement authorities providing assistance to other law enforcement authorities and Danish police conduct investigations on behalf of foreign counterparts as requested. If compulsion is needed to provide information, mutual legal assistance procedures and conditions will apply.

1000. Police authorities provide information on a spontaneous basis to foreign police authorities as well as provide information at foreign request. This may relate to any crime including a fiscal matter. No restrictions are placed on the use of information provided to other states other than that the data must be protected and used in connection with a criminal investigation. Law enforcement exchanges are premised upon adequate secrecy and data protection in the receiving country. Information from a foreign law enforcement authority receives the same protection as law enforcement information gathered on a domestic basis. In addition, it is used in accordance with any restrictions that the providing country has placed on the information.

1001. When Danish law enforcement authorities make a request, they indicate a reason for the request as well as relevant facts.

\section{FIU cooperation}

1002. The FIU is able to, and does, provide a wide range of international cooperation to foreign counterparts. It regularly receives and responds to requests for information from foreign FIUs. There are clear channels for its cooperation. It participates, together with the FSA, in the Money Laundering Contact Committee within the European Commission.

1003. The FIU maintains general statistics on requests received from its foreign counterparts since 2000. In 2004, for example, there were approximately 143 incoming inquiries. However, the FIU does not keep any statistics on requests, including spontaneous referrals, it has made to other countries. There are no statistics on how the requests are dealt with, how long they took to be processed and whether they have been acceded to or not. It is also not possible to determine how many of the statistics kept by the FIU relate to the FT.

1004. The FIU also has a close working relationship with its counterparts within the Egmont Framework and has served on Egmont's Legal Working Group. As a member of the Egmont Group, it cooperates with other FIUs in accordance with the Egmont Group principles. MOUs are not needed in order to cooperate with other FIUs, but the Danish FIU, with the approval of the MOJ has entered into a number of MOUs at the request of other States. The FIU has signed MOUs with Australia, Israel, and Canada, and is currently negotiating agreements with Panama, Thailand, Venezuela, Russia, South Korea, Mexico, the Dutch Antilles and Singapore. 
In addition, there is a Council 2000 Decision that addresses cooperation with other European FIUs.

1005. The FIU may conduct enquiries on behalf of foreign counterparts, and does so as requested. In this connection, it may search its own databases as well as law enforcement and other databases to which it has access. It may provide information to other FIUs both spontaneously and upon request as to any matter including fiscal matters. Requests of information are usually processed by the FIU within 3 working days, and where this is not possible, a preliminary answer is given. No request for information has ever been rejected.

1006. Procedures are in place for the provision of information to other FIUs. As long as the information is requested for a criminal investigation and the requesting State has adequate secrecy and data protection provisions, there are no restrictions on the provision of information. The recent FATF Secretariat survey of FATF and FSRB states did not reveal any problems in obtaining cooperation from the Danish FIU. There is in practice no difference in the scope of cooperation the FIU is able to afford to administrative FIUs compared with that given law enforcement FIUs. Danish authorities have granted all requests from FIUs, whether administrative or law enforcement, that were made in accordance with the Egmont Group requirements. With an administrative FIU, the Danish authorities must make a determination under the Danish Public Administration Act that an exchange may take place. As standards under the Act can be met in the case of FIU requests, although an additional step is part of the process, there is no issue in practice .For information that it does not already have, the FIU is generally able to obtain the information, including through a court order. If the request is from an administrative FIU, it may provide only information accessible through non-coercive measures.

1007. The FIU protects incoming information by treating it the same manner as the domestic information it receives and handles, and abides by any restrictions on use indicated by the providing country.

\section{Supervisory cooperation}

1008. The FSA has the ability to exchange information both spontaneously and upon request according to Section 347(5) and Section 354(5), nos. 14 and 15, of the FBA:

1009. The FSA can request information and documents from foreign banks and financial market supervisory authorities and has the authority to undertake direct inspections in foreign establishments of banks. As a member of the EU, Denmark takes part to the EU multilateral system of cooperation and information sharing, including several agreements with countries outside the EU. A number of bilateral MOUs on information sharing have also been agreed, including with the with UK, France, Germany, Ireland, Holland, Hong Kong, the other Scandinavian countries, Estonia and Lithuania. All these agreements contain provisions dealing with on-site inspections for branches and subsidiaries of Danish financial institutions located in thirdcountries. Such a agreements also contain provisions for cooperating in cases where there is a suspicion that financial crime is occurring in a supervised financial institution, including money laundering, terrorist financing and violations of laws on financial markets.

1010. The FBA stipulates the extent to which the FSA can forward confidential information to others and how these others are to treat the information in matters of confidentiality. Section 354/9 require that information can only be provided on the basis of international cooperation agreements and that the recipients of said information are, at a minimum, subject to a statutory duty of confidentiality. There exists no specific direct requirement for DFSA to take reasonable steps to ensure that any confidential information released to another supervisor will be used only for supervisory purposes.

1011. The FSA can deny any demand for confidential information, except in the cases mentioned in section $354 / 5$. If the DFSA has to forward any confidential information as a result of a demand mentioned in section $354 / 5$, the information will still have to be held confidential by the receiver. This is stipulated in section $354 / 6$.

1012. The Danish Commerce and Companies Agency can conduct inquiries on behalf of foreign 
counterparts.

1013. A survey of FATF/FSRB members conducted by the FATF does not reveal any particular problems in obtaining supervisory cooperation from Denmark.

\section{Recommendation 32}

1014. Statistics are not maintained on incoming and outgoing law enforcement requests relating to AML/CFT made on a police (rather than mutual legal assistance) basis through Europol or Interpol or other law enforcement channels. The FIU does not routinely maintain statistics on outgoing requests, but has maintained statistics on incoming requests for some years (for instance for 2004).

1015. At the time of the mission, the FSA kept few statistics on incoming and outgoing requests for cooperation and their disposition. Further to the mission's request, the authorities were, however, able to compile some estimates on the number of inquiries it has received since 2002 . That said, the authorities would benefit from systematically collecting statistics on incoming and outgoing requests, and their disposition.

\section{Recommendations and comments}

1016. Maintain more comprehensive statistics on law enforcement, FIU and supervisory international cooperation.

\section{Compliance with FATF Recommendations}

\begin{tabular}{|c|c|c|}
\hline & Rating & Summary of factors relevant to section 6.5 underlying overall rating \\
\hline R.40 & $\mathrm{C}$ & \\
\hline SR.V & $\mathrm{LC}$ & - $\quad[\mathrm{C}$ for Section 5.5.] \\
\hline
\end{tabular}

\section{Other Issues}

\subsection{Resources and statistics}

\begin{tabular}{|l|l|l|}
\hline \multicolumn{1}{|c|}{ Compliance with FATF Recommendations } \\
\hline R.30 & PC & \multicolumn{1}{|c|}{ Summary of factors relevant to section 5.5 underlying overall rating } \\
ThU: \\
The number of staff of the FIU appears to be insufficient, considering the likely \\
STRs, and the possibility that staff may be asked to conduct investigations for \\
the SØK. \\
The FIU staff could benefit from more specialized training in fields relevant to \\
money laundering and the financing of terrorism. \\
Law enforcement: \\
Law enforcement personnel do not receive sufficient training on ML and FT \\
typologies, on ML and FT issues as they arise in the Danish context and on \\
tracing techniques. \\
Financial supervisory:
\end{tabular}




\begin{tabular}{|c|c|c|}
\hline & & $\begin{array}{l}\text { Current staff resources of the FSA will be stretched given upcoming competing } \\
\text { priorities and need to increase scope and frequency of AML/CFT inspections. } \\
\text { Planned resources for the DCCA will not be sufficient to effectively supervise } \\
\text { money remitters and currency exchange, given the DCCA's other supervisory } \\
\text { responsibilities for DNFBPs and the need to increase the scope of inspections. } \\
\text { Insufficient training for FSA and DCCA staff in AML/CFT matters. }\end{array}$ \\
\hline R.32 & $\mathrm{PC}$ & $\begin{array}{l}\text { Law enforcement: } \\
\text { Statistics on ML investigations and prosecutions are not kept separately for } \\
\text { basic and aggravated ML offences. } \\
\text { Statistics are not currently kept on the number and kinds of cases (underlying } \\
\text { predicate crimes) in which confiscation is imposed, nor in which proceeds are } \\
\text { actually recovered. Only limited gross annual data on amounts confiscated is } \\
\text { maintained. } \\
\text { Danish authorities have not undertaken sufficiently comprehensive or regular } \\
\text { reviews of the effectiveness of their AML/CFT program. } \\
\text { Inadequate statistical information is maintained for law enforcement use on } \\
\text { ML investigations, prosecutions, convictions, on property frozen and } \\
\text { confiscated and on international requests } \\
\text { Denmark has not maintained statistics on the numbers or nature of mutual legal } \\
\text { assistance requests, including outcome, time for execution and crime involved } \\
\text { other than some statistics for FT. } \\
\text { Authorities just commenced maintaining statistics on extradition, and more } \\
\text { comprehensive statistics are needed that cover the nature of the request, } \\
\text { whether it is granted or refused and the time taken for responses. } \\
\text { FIU: } \\
\text { The system of keeping statistics could be improved whereby there is a more } \\
\text { comprehensive and organized compilation of data that would ensure a better } \\
\text { review of the effectiveness of the system. } \\
\text { Cash couriers: } \\
\text { Statistics maintained on STRs relating to cross-border currency matters and } \\
\text { those that come from Customs and Tax authorities should reflect whether a } \\
\text { STR involves a false declaration, a non-disclosure or another Customs } \\
\text { violation } \\
\text { National cooperation: } \\
\text { No regular review of effectiveness. } \\
\text { Financial supervisory: } \\
\text { Stics on formal requests for international assistance received and their }\end{array}$ \\
\hline
\end{tabular}




\begin{tabular}{|l|l|l|}
\hline \multirow{2}{*}{} & $\begin{array}{l}\text { disposition are not maintained in manner that would facilitate review of } \\
\text { effectiveness of cooperation } \\
\text { Other forms of international cooperation: } \\
\text { Statistics not maintained in a systematic fashion }\end{array}$ \\
\hline
\end{tabular}


Table 2. Ratings of Compliance with FATF Recommendations

\begin{tabular}{|c|c|c|}
\hline Forty Recommendations & Rating & Summary of factors underlying rating ${ }^{24}$ \\
\hline \multicolumn{3}{|l|}{ Legal systems } \\
\hline 1. ML offence & $\mathrm{LC}$ & $\begin{array}{l}\text { ML provisions in Greenland and the Faroe Islands } \\
\text { are not fully consistent with international standards } \\
\text { as reflected in the Vienna and Palermo Conventions } \\
\text { and FATF Recommendation } 1 \text { in that, for instance, } \\
\text { the range of predicate offenses is not adequate. } \\
\text { Denmark institutes very limited numbers of } \\
\text { prosecutions under its aggravated ML provision. }\end{array}$ \\
\hline $\begin{array}{l}\text { 2. ML offence-mental element and } \\
\text { corporate liability }\end{array}$ & $\mathrm{LC}$ & $\begin{array}{l}\text { Penalties imposed for ML offence are low. } \\
\text { Denmark institutes very limited numbers of } \\
\text { prosecutions under its aggravated ML provision. }\end{array}$ \\
\hline 3. Confiscation and provisional measures & $\mathrm{LC}$ & $\begin{array}{l}\text { Given the lack of meaningful data and regular } \\
\text { review of confiscation and tracing } \\
\text { efforts/accomplishments in Denmark, the tracing, } \\
\text { seizure and confiscation provisions were not shown } \\
\text { to have been fully implemented. } \\
\text { Work is not yet complete on updating Greenlandic } \\
\text { and Faroese provisions on tracing, seizure and } \\
\text { confiscation. }\end{array}$ \\
\hline \multicolumn{3}{|l|}{ Preventive measures } \\
\hline $\begin{array}{l}\text { 4. Secrecy laws consistent with the } \\
\text { Recommendations }\end{array}$ & $\mathrm{C}$ & \\
\hline 5. $\quad$ Customer due diligence & $\mathrm{PC}$ & $\begin{array}{l}\text { The new MLA is not yet applicable in Greenland } \\
\text { and in the Faroe Islands which remain subject to } \\
\text { the } 1993 \text { MLA. } \\
\text { There are no identification requirements in the case } \\
\text { of wire transfers under the circumstances covered } \\
\text { by SR VII (i.e., the identification requirements } \\
\text { apply only in the case of wire transfers of } 15.000 \\
\text { EUR or more). } \\
\text { There is no indication of the types of documents } \\
\text { which are to be verified during the identification } \\
\text { process. } \\
\text { In the case of a legal person, there is no } \\
\text { requirement to verify that the individual purporting } \\
\text { to act on behalf of the legal person or arrangement } \\
\text { is so authorized nor to identify and verify the } \\
\text { identity of that person } \\
\text { The conditions under which a financial institution } \\
\text { is required to determine whether the customer is }\end{array}$ \\
\hline
\end{tabular}




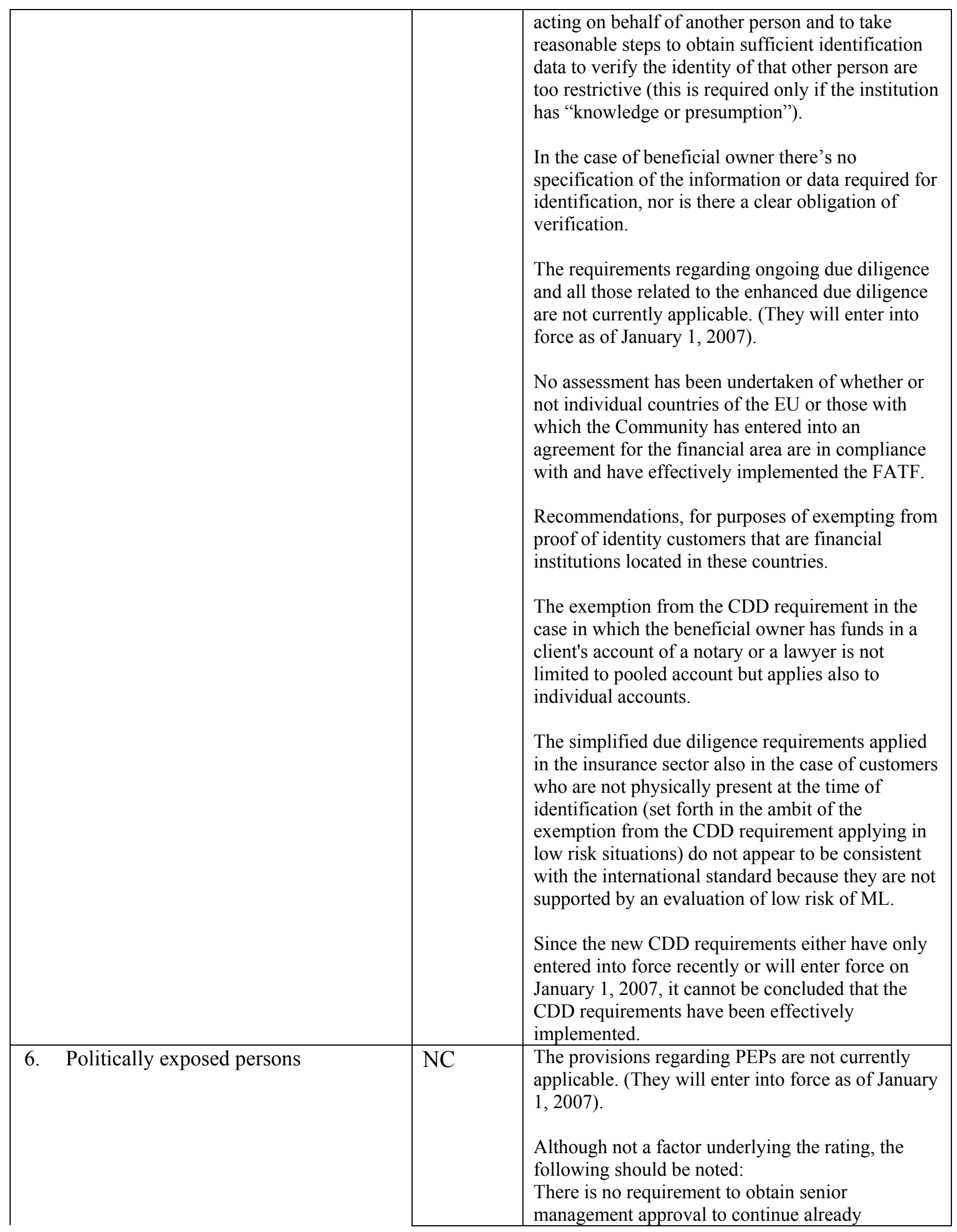




\begin{tabular}{|c|c|c|}
\hline & & established business relationships with a PEP. \\
\hline 7. Correspondent banking & $\mathrm{NC}$ & $\begin{array}{l}\text { The provisions regarding cross border } \\
\text { correspondent banking are currently not applicable. } \\
\text { (They will enter into force as of January 1,2007.) } \\
\text { Although not a factor underlying the rating, the } \\
\text { following should be noted: } \\
\text { There are some inconsistencies between the } \\
\text { legislation and FATF requirements: } \\
\text {-- the obligation for the correspondent institution to } \\
\text { gather sufficient information in order to determine } \\
\text { the reputation of the respondent institution and the } \\
\text { quality of supervision does not specifically mention } \\
\text { the obligation to determine whether the respondent } \\
\text { institution has been subject to a ML or TF } \\
\text { investigation or regulatory action. } \\
\text {-- while there is an obligation for the correspondent } \\
\text { institution to assess the respondent institution's } \\
\text { AML/CFT controls there is no obligation for the } \\
\text { correspondent institution to ascertain that these } \\
\text { controls are adequate and effective. } \\
\text {-- there is no requirement to document the } \\
\text { respective AML/CFT responsibilities of each } \\
\text { institution. }\end{array}$ \\
\hline $\begin{array}{l}\text { 8. New technologies \& non face-to-face } \\
\text { business }\end{array}$ & $\mathrm{NC}$ & $\begin{array}{l}\text { The requirements set forth for non-face-to face } \\
\text { transactions are not currently applicable. (They will } \\
\text { enter into force as of January 1,2007.) }\end{array}$ \\
\hline 9. Third parties and introducers & $\mathrm{NC}$ & $\begin{array}{l}\text { The requirements concerning reliance on third } \\
\text { parties are not practically enforceable in the case } \\
\text { where financial institutions being relied upon are } \\
\text { outside Denmark. Rather than placing an obligation } \\
\text { on institutions which are relying on third parties to } \\
\text { immediately obtain the necessary information } \\
\text { concerning the CDD process (as required by the } \\
\text { FATF standard), the MLA places the obligation on } \\
\text { the undertaking that is being relied upon to provide } \\
\text { CDD related information and to make immediately } \\
\text { available the proof of identity upon request. } \\
\text { There is no obligation for institutions relying on } \\
\text { third parties to take adequate steps to satisfy } \\
\text { themselves that copies of the identification data and } \\
\text { other relevant documentation that relate to the CDD } \\
\text { requirements will be made available from the third } \\
\text { party upon request without delay. } \\
\text { There is no requirement for financial institutions to } \\
\text { satisfy themselves that a third party located within } \\
\text { the EU or in a country with whom the Community }\end{array}$ \\
\hline
\end{tabular}




\begin{tabular}{|c|c|c|}
\hline & & $\begin{array}{l}\text { has entered into an agreement for the financial area } \\
\text { is regulated and supervised (in accordance with } \\
\text { Recommendation 23, } 24 \text { and 29), and has measures } \\
\text { in place to comply with, the CDD requirements set } \\
\text { out in R.5 and R.10. }\end{array}$ \\
\hline 10. Record keeping & $\mathrm{C}$ & \\
\hline 11. Unusual transactions & $\mathrm{NC}$ & $\begin{array}{l}\text { The requirement to investigate the purpose of the } \\
\text { complex/unusually large transactions and to keep } \\
\text { record of the findings is not applicable as it will } \\
\text { only enter into force on of January 1,2007. } \\
\text { The provision obliging to pay special attention to } \\
\text { customers' activities and to complex unusually } \\
\text { large transactions does not carry a sanction for } \\
\text { failure to comply and has only recently been } \\
\text { introduced such that it cannot be concluded that the } \\
\text { provision is effectively implemented. }\end{array}$ \\
\hline 12. DNFBP-R.5, $6,8-11$ & $\mathrm{NC}$ & $\begin{array}{l}\text { In the case of a legal person, there is no } \\
\text { requirement to verify that the individual purporting } \\
\text { on behalf of the legal person is so authorized nor to } \\
\text { identify and verify the identity of that person. } \\
\text { Similarly the requirements regarding the } \\
\text { verification of the legal status are not complete in } \\
\text { the case of legal persons, as the information related } \\
\text { to the CVR would not encompass the provisions } \\
\text { relating to the power to bind the legal person. The } \\
\text { same observations apply to the case of legal } \\
\text { arrangements (with reference to the name of the } \\
\text { trustee and the power to bind the legal } \\
\text { arrangement). } \\
\text { There is no general requirement for DNFBPs to } \\
\text { determine whether the customer is acting on behalf } \\
\text { of another person and to take reasonable steps to } \\
\text { obtain sufficient identification data to verify the } \\
\text { identity of that other person. } \\
\text { There is no obligation to verify the identity of the } \\
\text { beneficial owner, nor is there a specification of the } \\
\text { information or data required. } \\
\text { The FATF requirements regarding ongoing due } \\
\text { diligence and all those related to the enhanced due } \\
\text { diligence, PEPs, non-face-to-face transactions, and } \\
\text { unusual transaction reporting are not currently } \\
\text { applicable. (They will enter into force as of January } \\
1,2007 \text { ) } \\
\text { The FATF requirements regarding identification of } \\
\text { the beneficial owner and ascertaining a customers' } \\
\text { objectives in starting a business relationship have } \\
\text { been recently established and not yet effectively } \\
\text { implemented. }\end{array}$ \\
\hline
\end{tabular}




\begin{tabular}{|c|c|c|}
\hline & & $\begin{array}{l}\text { Casino legislation and procedures not in conformity } \\
\text { with FATF standards do not require identification } \\
\text { of customers making transactions above the FATF- } \\
\text { established threshold and do not comply with } \\
\text { FATF record-keeping requirements. } \\
\text { DNFBPs in Greenland/Faroe Islands are not } \\
\text { covered by AML/CFT laws or regulations. }\end{array}$ \\
\hline 13. Suspicious transaction reporting & $\mathrm{PC}$ & $\begin{array}{l}\text { Low level of reporting raises effectiveness } \\
\text { questions. } \\
\text { Negligible reporting from insurers and investment } \\
\text { managers. } \\
\text { Insufficient monitoring of financial institution } \\
\text { participation in the system. } \\
\text { Greenland/Faroe Islands reporting requirements do } \\
\text { not meet standards for TF and attempted } \\
\text { transactions. }\end{array}$ \\
\hline 14. Protection \& no tipping-off & $\mathrm{C}$ & \\
\hline 15. Internal controls, compliance \& audit & $\mathrm{LC}$ & $\begin{array}{l}\text { There are no requirements for screening procedures } \\
\text { for hiring employees or to maintain an independent } \\
\text { audit function to test compliance. } \\
\text { The scope and intensity of initial and ongoing } \\
\text { employee training programs appear to be } \\
\text { insufficient. }\end{array}$ \\
\hline 16. DNFBP-R.13-15 \& 21 & $\mathrm{PC}$ & $\begin{array}{l}\text { Low level of reporting raises concerns about } \\
\text { effectiveness of reporting by DNFBPs. } \\
\text { No Greenland/Faroe Islands coverage. } \\
\text { No TF reporting in casinos. } \\
\text { Indirect reporting for casinos. }\end{array}$ \\
\hline 17. Sanctions & $\mathrm{PC}$ & $\begin{array}{l}\text { No sanctions have ever been applied under the } \\
\text { previous Act. In the absence of pre-set fines or } \\
\text { range of fines and with no history of imposed fines } \\
\text { it is not possible to conclude that sanctions are } \\
\text { effective, proportionate or dissuasive. } \\
\text { Not all the obligations set forth in the MLA are } \\
\text { covered by a sanction. } \\
\text { Limited range of administrative sanctions to } \\
\text { enforce compliance: very limited authority to } \\
\text { impose fines; ability to remove senior manager } \\
\text { beyond board of management is fairly limited and, } \\
\text { in practice, relatively few other actions have been } \\
\text { have been taken to ensure compliance with } \\
\text { AML/CFT. }\end{array}$ \\
\hline
\end{tabular}




\begin{tabular}{|c|c|c|}
\hline 18. Shell banks & $\mathrm{PC}$ & $\begin{array}{l}\text { Measures not yet in force to prohibit the } \\
\text { continuance or entry into correspondent } \\
\text { relationship with shell banks and to avoid a } \\
\text { connection with credit institutions that permit their } \\
\text { accounts to be used by shell banks. }\end{array}$ \\
\hline 19. Other forms of reporting & $\mathrm{LC}$ & $\begin{array}{l}\text { No tangible evidence of recent proper consideration } \\
\text { of the feasibility and utility of implementing a } \\
\text { system whereby financial institutions report all } \\
\text { transactions in currency above a fixed threshold to } \\
\text { a centralized agency with a computerized database. }\end{array}$ \\
\hline $\begin{array}{l}\text { 20. Other NFBP \& secure transaction } \\
\text { techniques }\end{array}$ & $\mathrm{C}$ & \\
\hline $\begin{array}{l}\text { 21. Special attention for higher risk } \\
\text { countries }\end{array}$ & $\mathrm{PC}$ & $\begin{array}{l}\text { No broad requirement to pay special attention to } \\
\text { business relationships and transactions with persons } \\
\text { from countries which do not or insufficiently apply } \\
\text { the FATF recommendations. } \\
\text { Factors underlying the rating for R.11, also relevant } \\
\text { here (re. EC 21.2). }\end{array}$ \\
\hline 22. Foreign branches \& subsidiaries & $\mathrm{LC}$ & $\begin{array}{l}\text { The requirement is newly established and has not } \\
\text { yet been effectively implemented. }\end{array}$ \\
\hline $\begin{array}{l}\text { 23. Regulation, supervision and } \\
\text { monitoring }\end{array}$ & $\mathrm{PC}$ & $\begin{array}{l}\text { Overall the FSA's inspection policies and } \\
\text { procedures, and practice for AML/CFT are not } \\
\text { sufficient as regards scope and frequency. Similarly } \\
\text { for the DCCA, inspection policies and procedures, } \\
\text { and practice are not sufficient as regards scope. } \\
\text { Absence of fit and proper tests for credit card } \\
\text { companies, leasing, factoring and finance/consumer } \\
\text { credit, and money remitters in business prior to } \\
\text { March 1, 2006. } \\
\text { Limited regulation-making authority to set out } \\
\text { more detailed requirements for preventive } \\
\text { measures. } \\
\text { The additional supervisory responsibilities (FSA: } \\
\text { insurance brokers, credit card companies, leasing, } \\
\text { factoring and finance/consumer credit companies; } \\
\text { DCCA: particularly for currency exchangers but } \\
\text { also money remitters) - is too recent to be } \\
\text { effectively implemented. }\end{array}$ \\
\hline $\begin{array}{l}\text { 24. DNFBP - regulation, supervision and } \\
\text { monitoring }\end{array}$ & $\mathrm{NC}$ & $\begin{array}{l}\text { Major shortcomings in current supervision all } \\
\text { DNFBPs. }\end{array}$ \\
\hline 25. Guidelines \& Feedback & $\mathrm{NC}$ & $\begin{array}{l}\text { FIU: } \\
\text { No guidelines issued; } \\
\text { More feedback to reporting entities needed } \\
\text { Financial supervisory: } \\
\text { Virtual absence of formal guidelines. }\end{array}$ \\
\hline
\end{tabular}




\begin{tabular}{|c|c|c|}
\hline & & $\begin{array}{l}\text { DNFBPs: } \\
\text { Absence of guidelines from the competent } \\
\text { authorities, except for lawyers (but these are not up } \\
\text { to date with new MLA). }\end{array}$ \\
\hline \multicolumn{3}{|l|}{ Institutional and other measures } \\
\hline 26. The FIU & $\mathrm{LC}$ & $\begin{array}{l}\text { The analysis of the STRs is insufficient. } \\
\text { There are no requirements regarding the manner of } \\
\text { reporting, nor are there specification of reporting } \\
\text { forms or procedures that should be followed when } \\
\text { reporting. In particular the FIU has never issued } \\
\text { any format or template regarding the type of } \\
\text { information that an STR should contain. } \\
\text { The FIU can obtain additional data only through a } \\
\text { court order. This circumstanceis a shortcoming in } \\
\text { the FIU powers to promptly obtain additional } \\
\text { information which might be needed for the analysis } \\
\text { of the STRs. } \\
\text { While access to the FIU database is limited to staff } \\
\text { assigned to the FIU and there are rules prohibiting } \\
\text { other SØK staff access to the hard copy archive; the } \\
\text { hard copy archives of the FIU is on a practical } \\
\text { level physically accessible to SØK as well. }\end{array}$ \\
\hline 27. Law enforcement authorities & $\mathrm{C}$ & \\
\hline 28. Powers of competent authorities & $\mathrm{C}$ & \\
\hline 29. Supervisors & $\mathrm{LC}$ & $\begin{array}{l}\text { The additional supervisory responsibilities (FSA: } \\
\text { insurance brokers, credit card companies, leasing, } \\
\text { factoring and finance/consumer credit companies; } \\
\text { DCCA: particularly for currency exchangers) - is } \\
\text { too recent to be effectively implemented. } \\
\text { Limited range of administrative sanctions to } \\
\text { enforce compliance: very limited authority to } \\
\text { impose fines; inability to remove senior manager } \\
\text { beyond board of management is fairly limited; } \\
\text { limited authority to impose fines and, in practice, } \\
\text { relatively few other actions have been have been } \\
\text { taken to ensure compliance with AML/CFT. }\end{array}$ \\
\hline 30. Resources, integrity and training & $\mathrm{PC}$ & $\begin{array}{l}\text { FIU: } \\
\text { The number of staff of the FIU appears to be } \\
\text { insufficient, considering the likely increase in } \\
\text { numbers of STRs, the desirability of more } \\
\text { extensive analysis of STRs, and the possibility that } \\
\text { staff may be asked to conduct investigations for the } \\
\text { SØK. } \\
\text { The FIU staff could benefit from more specialized }\end{array}$ \\
\hline
\end{tabular}




\begin{tabular}{|c|c|c|}
\hline & & $\begin{array}{l}\text { training in fields relevant to money laundering and } \\
\text { the financing of terrorism. } \\
\text { Law enforcement: } \\
\text { Law enforcement personnel do not receive } \\
\text { sufficient training on ML and FT typologies, on } \\
\text { ML and FT issues as they arise in the Danish } \\
\text { context and on tracing techniques. } \\
\text { Financial supervisory: } \\
\text { Current staff resources of the FSA will be stretched } \\
\text { given upcoming competing priorities and need to } \\
\text { increase scope and frequency of AML/CFT } \\
\text { inspections. } \\
\text { Planned resources for the DCCA will not be } \\
\text { sufficient to effectively supervise money remitters } \\
\text { and currency exchange, given the DCCA's other } \\
\text { supervisory responsibilities for DNFBPs and the } \\
\text { need to increase the scope of inspections. } \\
\text { Insufficient training for FSA and DCCA staff in } \\
\text { AML/CFT matters. }\end{array}$ \\
\hline 31. National co-operation & $\mathrm{LC}$ & $\begin{array}{l}\text { FIU and supervisors are in ad hoc rather than } \\
\text { regular contact. } \\
\text { FIU and supervisors efforts regarding FT individual } \\
\text { state provided lists not yet fully coordinated. }\end{array}$ \\
\hline 32. Statistics & $\mathrm{PC}$ & $\begin{array}{l}\text { Law enforcement: } \\
\text { Statistics on ML investigations and prosecutions } \\
\text { are not kept separately for basic and aggravated ML } \\
\text { offences. } \\
\text { Statistics are not currently kept on the number and } \\
\text { kinds of cases (underlying predicate crimes) in } \\
\text { which confiscation is imposed, nor in which } \\
\text { proceeds are actually recovered. Only limited gross } \\
\text { annual data on amounts confiscated is maintained. } \\
\text { Danish authorities have not undertaken sufficiently } \\
\text { comprehensive or regular reviews of the } \\
\text { effectiveness of their AML/CFT program. } \\
\text { Inadequate statistical information is maintained for } \\
\text { law enforcement use on ML investigations, } \\
\text { prosecutions, convictions, on property frozen and } \\
\text { confiscated and on international requests } \\
\text { Denmark has not maintained statistics on the } \\
\text { numbers or nature of mutual legal assistance }\end{array}$ \\
\hline
\end{tabular}




\begin{tabular}{|c|c|c|}
\hline & & $\begin{array}{l}\text { requests, including outcome, time for execution and } \\
\text { crime involved other than some statistics for FT. } \\
\text { Authorities just commenced maintaining statistics } \\
\text { on extradition, and more comprehensive statistics } \\
\text { are needed that cover the nature of the request, } \\
\text { whether it is granted or refused and the time taken } \\
\text { for responses. } \\
\text { FIU: } \\
\text { The system of keeping statistics could be improved } \\
\text { whereby there is a more comprehensive and } \\
\text { organized compilation of data that would ensure a } \\
\text { better review of the effectiveness of the system. } \\
\text { Cash couriers: } \\
\text { Statistics maintained on STRs relating to cross- } \\
\text { border currency matters and those that come from } \\
\text { Customs and Tax authorities should reflect whether } \\
\text { a STR involves a false declaration, a non-disclosure } \\
\text { or another Customs violation } \\
\text { National cooperation: } \\
\text { No regular review of effectiveness. } \\
\text { Financial supervisory: } \\
\text { Statistics on formal requests for international } \\
\text { assistance received and their disposition are not } \\
\text { maintained in manner that would facilitate review } \\
\text { of effectiveness of cooperation } \\
\text { Other forms of international cooperation: } \\
\text { Statistics not maintained in a systematic fashion }\end{array}$ \\
\hline 33. Legal persons-beneficial owners & $\mathrm{PC}$ & $\begin{array}{l}\text { While the authorities rely on law enforcement and } \\
\text { inspection powers to get information about } \\
\text { beneficial owner of companies, this information is } \\
\text { available in a limited form (only for A/S and ApS, } \\
\text { in certain circumstances) and it is not up to date. } \\
\text { In the case of foreign companies no information } \\
\text { about beneficial owner is available. } \\
\text { In the case of bearer shares, information on the } \\
\text { beneficial owner is limited only to the shareholders } \\
\text { holding shares above a designated threshold. } \\
\text { Legislation is not fully applicable in Greenland and } \\
\text { Faroe Islands. }\end{array}$ \\
\hline
\end{tabular}




\begin{tabular}{|c|c|c|}
\hline $\begin{array}{l}\text { 34. Legal arrangements - beneficial } \\
\text { owners }\end{array}$ & $\mathrm{PC}$ & $\begin{array}{l}\text { Although the authorities indicate that there are no } \\
\text { trust registered in Denmark, the information which } \\
\text { would be subject to disclosure in the case of trusts } \\
\text { operating as foreign branch does not appear to be } \\
\text { sufficient. }\end{array}$ \\
\hline \multicolumn{3}{|l|}{ International Cooperation } \\
\hline 35. Conventions & $\mathrm{PC}$ & $\begin{array}{l}\text { Vienna, Palermo and Terrorist Financing } \\
\text { Conventions have not been extended to the Faroe } \\
\text { Islands and Greenland. }\end{array}$ \\
\hline 36. Mutual legal assistance (MLA) & $\mathrm{LC}$ & $\begin{array}{l}\text { Greenland and the Faroe Islands are not be able to } \\
\text { provide assistance in some ML and FT matters } \\
\text { given the narrower scope of the AML/CFT } \\
\text { provisions. Nor is assistance involving coercion } \\
\text { available in the case of states not a party to the } \\
\text { European Convention on MLA. }\end{array}$ \\
\hline 37. Dual criminality & $\mathrm{C}$ & \\
\hline 38. MLA on confiscation and freezing & $\mathrm{LC}$ & $\begin{array}{l}\text { Denmark fully complies but Greenland and the } \\
\text { Faroe Islands may not always be able expeditiously } \\
\text { to freeze and seize in ML matters both because of } \\
\text { dual criminality issues and because provisions need } \\
\text { updating. }\end{array}$ \\
\hline 39. Extradition & $\mathrm{LC}$ & $\begin{array}{l}\text { Denmark is fully compliant, but there are not } \\
\text { adequate conventions, laws and procedures for } \\
\text { extradition in the case of Greenland and the Faroe } \\
\text { Islands. }\end{array}$ \\
\hline 40. Other forms of co-operation & $\mathrm{C}$ & \\
\hline \multicolumn{3}{|l|}{ Nine Special Recommendations } \\
\hline Implement UN instruments & $\mathrm{PC}$ & $\begin{array}{l}\text { Greenland and the Faroe Islands have not yet fully } \\
\text { implemented the UNSCRs. } \\
\text { The Terrorist Financing Convention is not } \\
\text { applicable in Greenland and the Faroe Islands. } \\
\text { Denmark has not fully implemented SR } 1373 \text { in } \\
\text { that in non-UN list or EU designation matters, there } \\
\text { is a limitation on the assets of a terrorist or terrorist } \\
\text { organization that authorities are prepared to freeze } \\
\text { (only assets intended for use for terrorism } \\
\text { purposes). }\end{array}$ \\
\hline SR.II Criminalize terrorist financing & $\mathrm{PC}$ & $\begin{array}{l}\text { The criminalization of the financing of terrorism by } \\
\text { Denmark is fully compliant, but Greenland and the } \\
\text { Faroe Islands have not yet adequately criminalized } \\
\text { the financing of terrorism, terrorists and terrorist } \\
\text { organizations. }\end{array}$ \\
\hline $\begin{array}{ll}\text { SR.III } & \text { Freeze and confiscate terrorist } \\
\text { assets }\end{array}$ & $\mathrm{PC}$ & $\begin{array}{l}\text { In contrast to freezes related to EU regulations, } \\
\text { authorities are not prepared under their domestic } \\
\text { framework to freeze non-terrorism related assets of } \\
\text { terrorists and terrorist organizations. } \\
\text { Denmark has issued some but not sufficient }\end{array}$ \\
\hline
\end{tabular}




\begin{tabular}{|c|c|c|}
\hline & & $\begin{array}{l}\text { practical guidance to institutions or other persons or } \\
\text { entities that may be holding funds or other assets } \\
\text { concerning obligations and procedures including } \\
\text { those to authorize access to funds. } \\
\text { In the case of Greenland and Faroe Islands, to } \\
\text { which the EU Regulations } 881 / 2002 \text { and } \\
2580 / 2001 \text { do not apply, all the necessary legal and } \\
\text { practical arrangements to enable the jurisdictions to } \\
\text { comply in each instance with the freeze } \\
\text { requirements of relevant UN resolutions are not in } \\
\text { place. } \\
\text { Procedures for dissemination of lists forwarded by } \\
\text { countries are not sufficient to ensure all institutions } \\
\text { and others have notice. } \\
\text { Institutions have not always received feedback } \\
\text { regarding possible name matches. }\end{array}$ \\
\hline $\begin{array}{ll}\text { SR.IV } & \begin{array}{l}\text { Suspicious transaction } \\
\text { Reporting }\end{array}\end{array}$ & $\mathrm{LC}$ & $\begin{array}{l}\text { No reporting requirement in Greenland/Faroe } \\
\text { Islands. }\end{array}$ \\
\hline SR.V International cooperation & $\mathrm{LC}$ & $\begin{array}{l}\text { Denmark fully complies but Greenland and the } \\
\text { Faroe Islands may not be able to provide mutual } \\
\text { legal assistance for all requests that relate to the } \\
\text { financing of terrorism. } \\
\text { Denmark is fully compliant, but Greenland and the } \\
\text { Faroe Islands do not meet the requirement that they } \\
\text { not serve as possible safe havens because of the } \\
\text { limited scope for criminalization of the financing of } \\
\text { terrorism and inadequate extradition provisions. }\end{array}$ \\
\hline $\begin{array}{ll}\text { SR.VI } & \text { AML/CFT requirements for } \\
& \text { money/value transfer services }\end{array}$ & $\mathrm{LC}$ & $\begin{array}{l}\text { Fit and proper test not applicable for money } \\
\text { remitters in business prior to March 1, } 2006 . \\
\text { The scope of inspection policies and procedures, } \\
\text { and practice are not sufficient. }\end{array}$ \\
\hline SR.VII Wire transfer rules & $\mathrm{PC}$ & $\begin{array}{l}\text { The situations in which the requirements apply are } \\
\text { narrower than the ones provided for by the standard } \\
\text { (i.e., they do not apply to incoming payments, } \\
\text { where the sender has personal contact with the } \\
\text { intermediary or where the sender has an account } \\
\text { with the intermediary). } \\
\text { There is no reference to the obligation to obtain and } \\
\text { maintain the originator's account number, though } \\
\text { this is mitigated by the required inclusion of CPR } \\
\text { and CVR numbers. }\end{array}$ \\
\hline SR.VIII Nonprofit organizations & $\mathrm{LC}$ & $\begin{array}{l}\text { Review of adequacy of legal and regulatory regime } \\
\text { only informal. }\end{array}$ \\
\hline $\begin{array}{ll}\text { SR.IX } & \begin{array}{l}\text { Cross-border declaration \& } \\
\text { disclosure }\end{array}\end{array}$ & $\mathrm{PC}$ & $\begin{array}{l}\text { There is a need for practical guidance and } \\
\text { instructions for line officers making the cross- } \\
\text { border checks and implementing the declaration }\end{array}$ \\
\hline
\end{tabular}




\begin{tabular}{|l|l|l|}
\hline & & $\begin{array}{l}\text { system. } \\
\text { Effectiveness concerns based on the low number of } \\
\text { declarations. }\end{array}$ \\
$\begin{array}{l}\text { No fines have been imposed in cases of non- } \\
\text { compliance. }\end{array}$ \\
$\begin{array}{l}\text { Declaration form information though sent to the } \\
\text { FIU is not organized and made readily usable. }\end{array}$ \\
\hline
\end{tabular}


Table 3: Recommended Action Plan to Improve the AML/CFT System

\begin{tabular}{|c|c|}
\hline FATF 40+9 Recommendations & Recommended Action (listed in order of priority) \\
\hline 1. General & No text required \\
\hline $\begin{array}{l}\text { 2. Legal System and Related } \\
\text { Institutional Measures }\end{array}$ & \\
\hline $\begin{array}{l}\text { Criminalization of Money } \\
\text { Laundering (R.1, } 2 \text { \& 32) }\end{array}$ & $\begin{array}{l}\text { Use the criminal ML provision more effectively by developing } \\
\text { and prosecuting a larger number of cases involving serious ML. } \\
\text { Seek to increase the penalties actually imposed for violations of } \\
\text { the ML provision. } \\
\text { Increase the maximum penalty available for the negligent money } \\
\text { laundering offence. } \\
\text { Make the provisions that criminalize money laundering in } \\
\text { Greenland and the Faroe Islands fully consistent with the } \\
\text { requirements of Article } 3 \text { of the Vienna Convention and Article } 6 \\
\text { of the Palermo Convention, and use one of the approaches to } \\
\text { predicate offenses set forth in the FATF Recommendations. } \\
\text { Consider the extent to which Denmark may be able to criminalize } \\
\text { self-laundering separately, recognizing that while not a FATF R. } 1 \\
\text { requirement where contrary to the general principles of penal law, } \\
\text { countries with similar legal systems have progressively moved } \\
\text { towards providing for self-laundering as a separate offence that } \\
\text { can be charged with a predicate offence. } \\
\text { Keep more comprehensive statistics on ML cases including the } \\
\text { kinds of cases (Section } 290(1) \text { or } 290(2) \text { ) and predicate offences, } \\
\text { and evaluate the reasons for the limited numbers of prosecutions } \\
\text { under Section } 290(2) \text {. }\end{array}$ \\
\hline $\begin{array}{l}\text { Criminalization of Terrorist } \\
\text { Financing (SR.II \& R.32) }\end{array}$ & $\begin{array}{l}\text { Denmark has criminalized FT in compliance with the Convention. } \\
\text { However, as authorities recognize and are working on, Greenland } \\
\text { and the Faroe Islands need to enact specific provisions that } \\
\text { criminalize the financing of terrorist acts, terrorists and terrorist } \\
\text { organizations in a manner consistent with the Terrorist Financing } \\
\text { Convention and not continue to rely upon the current approach of } \\
\text { complicity in the commission of a concrete terrorist act. TF } \\
\text { offences should be designated as predicate crimes to ML. The } \\
\text { current provisions, together with the fact that the Terrorist } \\
\text { Financing Convention has not been extended to these jurisdictions } \\
\text { and extradition problematic, leave Greenland and the Faroe } \\
\text { Islands vulnerable in the area of terrorist financing. }\end{array}$ \\
\hline $\begin{array}{l}\text { Confiscation, freezing and seizing of } \\
\text { proceeds of crime (R.3 \& 32) }\end{array}$ & $\begin{array}{l}\text { Authorities should evaluate on a regular basis the use of their } \\
\text { comprehensive tracing powers, and seizure and confiscation } \\
\text { provisions to determine whether they are being used effectively to } \\
\text { recover proceeds. In connection with this, there should be a review } \\
\text { of amounts confiscated, supplementary fines recovered and victim }\end{array}$ \\
\hline
\end{tabular}




\begin{tabular}{|c|c|}
\hline & $\begin{array}{l}\text { compensation paid (and the number of cases in which this occurs), } \\
\text { as well as levels of success in tracing proceeds from proceeds } \\
\text { generating crimes and in seizing early in a proceeding to secure } \\
\text { final orders. } \\
\text { Authorities should gather meaningful statistics and use them in } \\
\text { reviewing effectiveness. } \\
\text { Greenland and the Faroe Islands appear as reservations with } \\
\text { respect to the Kingdom of Denmark's ratification of the Vienna } \\
\text { and Palermo Conventions. Authorities should proceed with putting } \\
\text { into place any missing the legal and practical requisites for tracing, } \\
\text { seizing and confiscating proceeds in all cases, work that } \\
\text { authorities indicate has already been initiated. } \\
\text { While quite comprehensive and robust in many respects, } \\
\text { Denmark's confiscation scheme lacks a provision for the } \\
\text { continuation of confiscation proceedings in the case of an } \\
\text { absconding defendant. Authorities should consider such a } \\
\text { provision. }\end{array}$ \\
\hline $\begin{array}{l}\text { Freezing of funds used for terrorist } \\
\text { financing (SR.III \& R.32) }\end{array}$ & $\begin{array}{l}\text { Danish authorities should be prepared in accordance with UNSCR } \\
\text { 1373, Article 1(c) and SR III in every case to freeze all assets of } \\
\text { terrorists and terrorist organization (not only those that may be } \\
\text { used for terrorist purposes) and not limit a freeze of all assets to } \\
\text { situations when there is a directly applicable freeze through EU } \\
\text { regulations. } \\
\text { Danish authorities should provide additional written guidance to } \\
\text { the financial sector and designated non-financial businesses and } \\
\text { professions and others that may be holding funds or other assets } \\
\text { about the practical aspects of their obligations under the freezing } \\
\text { regime. procedures for access to funds and the de-freezing } \\
\text { processes. } \\
\text { Greenland and Faroe Islands should adopt legal provisions and } \\
\text { implementation measures to facilitate compliance with the UN } \\
\text { Resolutions. } \\
\text { The FIU should undertake additional efforts to ensure that all } \\
\text { appropriate institutions and persons receive notice regarding lists } \\
\text { forwarded by countries and not publicly available. } \\
\text { Authorities should ensure institutions making inquiries about } \\
\text { possible name matches receive prompt feedback. } \\
\text { Although law enforcement officials check listed names against } \\
\text { various data-bases, in addition, property ownership registers (for } \\
\text { instance real estate and ships) should be reviewed to determine } \\
\text { whether a listed individual or organization holds property in } \\
\text { Denmark, and the property encumbered. } \\
\text { Danish authorities should distribute lists to property transfer }\end{array}$ \\
\hline
\end{tabular}




\begin{tabular}{|c|c|}
\hline & $\begin{array}{l}\text { agents as real estate agents and brokers. Authorities indicated that } \\
\text { post-mission, this has been undertaken. }\end{array}$ \\
\hline $\begin{array}{l}\text { The Financial Intelligence Unit and } \\
\text { its functions (R.26, } 30 \& 32 \text { ) }\end{array}$ & $\begin{array}{l}\text { The analysis of STRs should be enhanced beyond simple data } \\
\text { matching and the role of the FIU in analyzing the STRs and in } \\
\text { substantiating suspicions should be strengthened, also with the to } \\
\text { improve the quality of the information that is disseminated for } \\
\text { investigation. } \\
\text { There should be written requirements regarding the manner of } \\
\text { reporting, as well as reporting forms or procedures that should be } \\
\text { followed when reporting. } \\
\text { Considering the likely increase in numbers of STRs, the } \\
\text { desirability of more extensive analysis of STRs, and the possibility } \\
\text { that staff may be asked to conduct investigations for the SØK, the } \\
\text { staff of the FIU should be increased. } \\
\text { More specialized training should be made available to the FIU } \\
\text { staff. }\end{array}$ \\
\hline $\begin{array}{l}\text { Law enforcement, prosecution and } \\
\text { other competent authorities (R.27, } \\
28,30 \& 32 \text { ) }\end{array}$ & $\begin{array}{l}\text { Danish authorities should use the Money Laundering Steering } \\
\text { Committee or another like mechanism to regularly evaluate the } \\
\text { effectiveness of its AML/CFT program. As it relates to the law } \\
\text { enforcement aspects of AML/CFT, the committee would consider } \\
\text { such matters as investigations and cases instituted, the nature of } \\
\text { such cases and the success in tracing, seizing, and recovering } \\
\text { proceeds (or alternatively the success in imposing and collecting } \\
\text { fines that are equivalent to the proceeds amounts). } \\
\text { Denmark should improve its statistics gathering and analysis of } \\
\text { such statistics. } \\
\text { More particularized training that covers ML and FT typologies, } \\
\text { and ML and FT issues as they may arise in the Danish context, as } \\
\text { well as more intensive training on techniques for tracing property } \\
\text { and ensuring it is seized, frozen and confiscated would be helpful. }\end{array}$ \\
\hline $\begin{array}{l}\text { Cross-border declaration \& } \\
\text { disclosure }\end{array}$ & $\begin{array}{l}\text { There should be practical guidelines for customs officers to guide } \\
\text { them regarding to how to implement the system, including more } \\
\text { practical and precise information regarding the exact instruments } \\
\text { in addition to monies that are subject to the declaration obligation. } \\
\text { Authorities should consider goals and strategies for the program } \\
\text { and methods to encourage a greater level of compliance and } \\
\text { improved levels of detection. } \\
\text { Sanctions should be used and appropriate fines be imposed to } \\
\text { ensure compliance. } \\
\text { There should be system to check for previous history of persons } \\
\text { involved in non-declaration or false declarations. }\end{array}$ \\
\hline
\end{tabular}




\begin{tabular}{|c|c|}
\hline & $\begin{array}{l}\text { The customs and tax authorities and the FIU should work in closer } \\
\text { collaboration regarding the implementation of the obligation. } \\
\text { Policies and practices regarding detentions and seizures of monies } \\
\text { should be reviewed to determine why all monies have been } \\
\text { returned. } \\
\text { There is a need to reinforce the system whereby all information } \\
\text { relating to the evolution of any particular cross-border } \\
\text { investigation is recorded for intelligence and investigation } \\
\text { purposes. } \\
\text { Efforts should be undertaken to maintain declaration records in a } \\
\text { way such that information is organised and readily usable. }\end{array}$ \\
\hline $\begin{array}{l}\text { 3. Preventive Measures-Financial } \\
\text { Institutions }\end{array}$ & \\
\hline $\begin{array}{l}\text { Risk of money laundering or terrorist } \\
\text { financing }\end{array}$ & \\
\hline $\begin{array}{l}\text { Customer due diligence, including } \\
\text { enhanced or reduced measures } \\
\text { (R.5-8) }\end{array}$ & $\begin{array}{l}\text { Denmark should extend the applicability of the new MLA to } \\
\text { Greenland and the Faroe Islands. } \\
\text { The identification requirements should be aligned to take also into } \\
\text { account the circumstances set forth by SRVII in the case of wire } \\
\text { transfer } \\
\text { There should be an indication (either in a regulation or by } \\
\text { guidance from the authority) of the types of documents which are } \\
\text { to be verified during the identification process. } \\
\text { An assessment should be made of whether or not individual } \\
\text { countries of the EU or those with which the Community has } \\
\text { entered into an agreement for the financial area are in compliance } \\
\text { with and have effectively implemented the FATF } \\
\text { Recommendations, for purposes of exempting from proof of } \\
\text { identity customers that are financial institutions located in these } \\
\text { countries. } \\
\text { In the case of a legal person the law (or a regulation) should } \\
\text { require verification that the individual purporting to act on behalf } \\
\text { of the legal person or arrangement is so authorized and should } \\
\text { require the identification and verification of the identity of that } \\
\text { person. Guidance should be provided concerning the verification } \\
\text { of identity of legal arrangements such as trust } \\
\text { There should be a general clear requirement for financial } \\
\text { institution to determine whether the customer is acting on behalf } \\
\text { of another person and an obligation to take reasonable steps to } \\
\text { obtain sufficient identification data to verify the identity of that } \\
\text { other person. } \\
\text { In addition to the existing obligation to identify the beneficial } \\
\text { owner there should also be an obligation to verify the identity of }\end{array}$ \\
\hline
\end{tabular}




\begin{tabular}{|c|c|}
\hline & $\begin{array}{l}\text { the beneficial owner, and a specification of the information or data } \\
\text { required in this process. } \\
\text { The exemption of the CDD requirement in the case in which the } \\
\text { beneficial owner has funds in a client's account of a notary or a } \\
\text { lawyer should be limited to the case of pooled account only. } \\
\text { Supervisory authorities are encouraged to issue guidance on the } \\
\text { risk sensitive approach. } \\
\text { In the case of PEPs, there should be a requirement to obtain senior } \\
\text { management approval to continue already established business } \\
\text { relationships with a PEP. } \\
\text { The Act should empower supervisory authorities to issue } \\
\text { regulations in the area of PEPs. } \\
\text { There should be provisions to require financial institutions to } \\
\text { document the respective responsibilities of the correspondent and } \\
\text { respondent institutions and determine if the respondent bank has } \\
\text { been the subject of an ML or FT investigation. } \\
\text { Close associates of PEPs should be considered to have risks } \\
\text { similar to that associated with PEPs. }\end{array}$ \\
\hline $\begin{array}{l}\text { Third parties and introduced business } \\
\text { (R.9) }\end{array}$ & $\begin{array}{l}\text { The obligation that is currently imposed on the third party to } \\
\text { immediately obtain the necessary information concerning the } \\
\text { CDD process should be redrafted to impose the obligation on the } \\
\text { financial institution that is relying on the third party. } \\
\text { The MLA should provide an obligation for institutions relying on } \\
\text { third parties to take adequate steps to satisfy themselves that } \\
\text { copies of the identification data and other relevant documentation } \\
\text { relate to the CDD requirements be made available from the third } \\
\text { party upon request without delay. } \\
\text { Consideration should be given to introducing a requirement for } \\
\text { financial institutions to satisfy themselves that a third party located } \\
\text { within the EU or in a country with whom the Community has } \\
\text { entered into an agreement for the financial area is regulated and } \\
\text { supervised (in accordance with Recommendation } 23,24 \text { and } 29 \text { ), } \\
\text { and has measures in place to comply with, the CDD requirements } \\
\text { set out in R.5 and R.10. Alternatively, the authorities should } \\
\text { conduct a thorough assessment of the supervisory framework and } \\
\text { of the CDD measures in place in the concerned countries where } \\
\text { the third parties are located and limit the location of third parties } \\
\text { to those countries that have satisfactory supervisory framework } \\
\text { and CDD measures. }\end{array}$ \\
\hline \multicolumn{2}{|l|}{$\begin{array}{l}\text { Financial institution secrecy or } \\
\text { confidentiality (R.4) }\end{array}$} \\
\hline $\begin{array}{l}\text { Record keeping and wire transfer } \\
\text { rules (R.10 \& SR.VII) }\end{array}$ & $\begin{array}{l}\text { The requirements for wire transfers should be aligned with the } \\
\text { international standard (they are currently limited to outgoing } \\
\text { payments; not applicable in the case of personal contact and in the }\end{array}$ \\
\hline
\end{tabular}




\begin{tabular}{|c|c|}
\hline & case where the sender has an account with the intermediary). \\
\hline $\begin{array}{l}\text { Monitoring of transactions and } \\
\text { relationships (R.11 \& 21) }\end{array}$ & $\begin{array}{l}\text { Requirement to investigate the purpose of the complex/unusually } \\
\text { large transactions and to keep record of the findings will only } \\
\text { enter into force on of January } 1,2007 \text {. } \\
\text { Guidance from supervisory authorities would be helpful as to how } \\
\text { implement the provision to monitor customers' activities. } \\
\text { A broader requirement to pay special attention to business } \\
\text { relationships and transactions with persons from countries which } \\
\text { do not or insufficiently apply the FATF recommendations should } \\
\text { be introduced. }\end{array}$ \\
\hline $\begin{array}{l}\text { Suspicious transaction reports and } \\
\text { other reporting (R.13, 14, 19, } 25 \text { \& } \\
\text { SR.IV) }\end{array}$ & $\begin{array}{l}\text { Explore the possibility of removing the misalignment between the } \\
\text { criminalization standard and the reporting requirement. } \\
\text { Take measures to ensure that employees in reporting entities } \\
\text { maintain high levels of vigilance, despite the restricted nature of } \\
\text { the reporting requirement. } \\
\text { Assess effectiveness of the suspicious activity reporting regime to } \\
\text { check for potential under-reporting. } \\
\text { Adopt measures that bring the reporting regime in Greenland and } \\
\text { the Faroe Islands up to international standards, especially in the } \\
\text { area of terrorist financing. } \\
\text { Enhance outreach to insurers and investment agents. } \\
\text { Consider adopting measures to protect those who suspend } \\
\text { transactions associated with money laundering from liability. }\end{array}$ \\
\hline $\begin{array}{l}\text { Cross Border Declaration or } \\
\text { disclosure (SR IX) }\end{array}$ & \\
\hline $\begin{array}{l}\text { Internal controls, compliance, audit } \\
\text { and foreign branches (R.15 \& 22) }\end{array}$ & $\begin{array}{l}\text { Guidance should be provided to the financial institutions to ensure } \\
\text { that the compliance officer or other appropriate staff has access to } \\
\text { customer records and relevant information. } \\
\text { The scope and intensity of initial and ongoing employee training } \\
\text { programs should be stepped up. } \\
\text { Requirements should be introduced to ensure that reporting } \\
\text { entities have adequate screening procedures for hiring employees }\end{array}$ \\
\hline Shell banks (R.18) & $\begin{array}{l}\text { The provisions that address deficiencies will come into force on } \\
\text { January } 1,2007 \text {. }\end{array}$ \\
\hline $\begin{array}{l}\text { The supervisory and oversight } \\
\text { system-competent authorities and } \\
\text { SROs } \\
\text { Role, functions, duties and }\end{array}$ & $\begin{array}{l}\text { FSA inspection policies and procedures, and practice for } \\
\text { AML/CFT should be reviewed and improved as regards the scope } \\
\text { and frequency of inspections. Similarly for the DCCA, inspection } \\
\text { policies and procedures, and practice should be reviewed and } \\
\text { improved as regards their scope. }\end{array}$ \\
\hline
\end{tabular}




\begin{tabular}{|c|c|}
\hline $\begin{array}{l}\text { powers (including sanctions) } \\
\text { (R.23, 30, 29, 17, } 25 \& 32 \text { ) }\end{array}$ & $\begin{array}{l}\text { The effectiveness of the powers of supervisory authorities to } \\
\text { sanction for non-compliance should be reviewed. } \\
\text { Fit and proper criteria should be introduced for the registration of } \\
\text { credit card companies, leasing, factoring and finance/consumer } \\
\text { credit, and money remitters in business prior to March 1, } 2006 \text {. } \\
\text { Detailed regulations and formal guidelines should be introduced to } \\
\text { elaborate and clarify best practice for complying with the MLA. } \\
\text { Adequacy of current staff resources of the FSA allocated to } \\
\text { AML/CFT should be reviewed given upcoming competing } \\
\text { priorities and the need to increase scope and frequency of } \\
\text { AML/CFT inspections. } \\
\text { Resources of the DCCA allocated to AML/CFT (notably for } \\
\text { inspections of money remitters and currency exchangers) should } \\
\text { be increased, given its other supervisory responsibilities for } \\
\text { DNFBPs and the need to increase the scope of inspections. } \\
\text { Training of FSA and DCCA staff on AML/CFT matters should be } \\
\text { considerably expanded. } \\
\text { Statistics on formal requests for assistance received and their } \\
\text { disposition should be kept in better form to facilitate the review of } \\
\text { effectiveness of cooperation. }\end{array}$ \\
\hline $\begin{array}{l}\text { Money value transfer services } \\
\text { (SR.VI) }\end{array}$ & $\begin{array}{l}\text { The DCCA should reconsider applying the fit and proper test } \\
\text { requirements also to undertakings that were carrying out the MVT } \\
\text { activities before the entry into force of the new MLA. } \\
\text { The DCCA's inspection policies and procedures, and practice } \\
\text { should be reviewed and improved as regards their scope. }\end{array}$ \\
\hline $\begin{array}{l}\text { 4. Preventive Measures- } \\
\text { Nonfinancial Businesses and } \\
\text { Professions }\end{array}$ & \\
\hline $\begin{array}{l}\text { Customer due diligence and record- } \\
\text { keeping (R.12) }\end{array}$ & $\begin{array}{l}\text { The legal and regulatory provisions for casinos and gaming should } \\
\text { be updated to bring the CDD requirements in line with the } \\
\text { international standard, including CFT provisions and CDD } \\
\text { measures and application to internet gaming } \\
\text { Establish clearer guidelines on appropriate identity verification } \\
\text { procedures and documents (especially for legal persons). } \\
\text { Strengthen procedures for ascertaining beneficial owner } \\
\text { information, especially where financial institutions are allowed to } \\
\text { rely on the CDD efforts of lawyers. } \\
\text { DNFBPs should be obliged to determine if a customer is acting on } \\
\text { behalf of another customer, rather than taking actions when they } \\
\text { suspect that to be the case. }\end{array}$ \\
\hline
\end{tabular}




\begin{tabular}{|c|c|}
\hline & $\begin{array}{l}\text { Casino procedures should be enhanced to provide identification of } \\
\text { customers making transactions above the FATF-established } \\
\text { threshold and to comply with FATF record-keeping requirements. } \\
\text { The AML/CFT regime should be extended to DNFBPs in } \\
\text { Greenland and the Faroe Islands. }\end{array}$ \\
\hline $\begin{array}{l}\text { Suspicious transaction reporting } \\
\text { (R.16) }\end{array}$ & $\begin{array}{l}\text { While the legal and regulatory basis for the reporting requirement } \\
\text { is generally sound, the low level of reporting raises basic questions } \\
\text { about the effectiveness of implementation. } \\
\text { Explore the possibility of removing the misalignment between the } \\
\text { criminalization standard and the reporting requirement. } \\
\text { The reporting provisions of the new MLA should be extended to } \\
\text { Greenland and Faroese DNFBPs } \\
\text { The laws and regulations governing casinos should be enhanced to } \\
\text { include reporting suspicions of terrorist financing and } \\
\text { consideration given to streamlining the reporting process. } \\
\text { Measures should be taken to enhance the effectiveness of the } \\
\text { reporting requirement for DNFBPs, including improving outreach } \\
\text { to the sectors and ensuring that internal procedures, training, and } \\
\text { compliance arrangements are sufficient to ensure adequate and } \\
\text { accurate reporting }\end{array}$ \\
\hline $\begin{array}{l}\text { Regulation, supervision, monitoring, } \\
\text { and sanctions (R.24 \& 25) }\end{array}$ & $\begin{array}{l}\text { Casino inspectors should also monitor casino compliance with } \\
\text { AML preventative measures (and CFT when the legal basis is } \\
\text { changed). } \\
\text { The Bar and Law Society should more directly engage in the } \\
\text { supervision of its members for compliance with AML/CFT } \\
\text { preventative measures under the MLA. } \\
\text { The DCCA should move forward decisively to put supervision of } \\
\text { other DNFBPs in place. } \\
\text { Planned resources for the DCCA will not be sufficient to } \\
\text { effectively supervise DNFBPs, given the DCCA's other } \\
\text { supervisory responsibilities for money remitters and currency } \\
\text { exchange and the need to increase the scope of inspections. } \\
\text { All professional associations should update their guidelines in } \\
\text { light of the new MLA, with the active participation of the FIU, } \\
\text { FSA, and DCCA. } \\
\text { Competent authorities and supervisors should enhance outreach } \\
\text { and training on AML/CFT issues and obligations for DNFBP } \\
\text { practitioners. }\end{array}$ \\
\hline Unter designated & \\
\hline
\end{tabular}




\begin{tabular}{|c|c|}
\hline businesses and professions (R.20) & \\
\hline $\begin{array}{l}\text { 5. Legal Persons and } \\
\text { Arrangements \& Nonprofit } \\
\text { Organizations }\end{array}$ & \\
\hline $\begin{array}{l}\text { Legal Persons-Access to beneficial } \\
\text { ownership and control information } \\
\text { (R.33) }\end{array}$ & $\begin{array}{l}\text { The information on beneficial ownership of legal persons should } \\
\text { be more accurate and up to date, especially in the case of foreign } \\
\text { legal persons. } \\
\text { Evaluate the ML/TF risks associated with the use of bearer shares } \\
\text { and take appropriate action. }\end{array}$ \\
\hline $\begin{array}{l}\text { Legal Arrangements-Access to } \\
\text { beneficial ownership and control } \\
\text { information (R.34) }\end{array}$ & $\begin{array}{l}\text { Measures should be taken to ensure transparency of foreign trust } \\
\text { and to get access to adequate, accurate and timely information on } \\
\text { beneficial ownership. }\end{array}$ \\
\hline Nonprofit organizations (SR.VIII) & $\begin{array}{l}\text { The Danish authorities should undertake a formal review, } \\
\text { involving all relevant agencies, of the adequacy of their legal, } \\
\text { regulatory, registration, and taxation systems to meet the new } \\
\text { international standard as elaborated in new FATF Interpretive } \\
\text { Note on SR VIII. } \\
\text { The Danish authorities should increase their outreach to the NPO } \\
\text { sector to raise awareness of the dangers and indicators of terrorist } \\
\text { financing through the NPO sector. } \\
\text { The Danish authorities should work with the NPO sector to } \\
\text { develop and refine best practices to address TF risks and } \\
\text { vulnerabilities and to encourage their widest adoption. }\end{array}$ \\
\hline $\begin{array}{l}\text { 6. National and International } \\
\text { Cooperation }\end{array}$ & \\
\hline $\begin{array}{l}\text { National cooperation and } \\
\text { coordination (R.31 \& 32) }\end{array}$ & $\begin{array}{l}\text { A platform should be established and used for regular inter-agency } \\
\text { policy level review of current AML/CFT initiatives (including } \\
\text { both the preventive and criminal justice aspects), their } \\
\text { effectiveness and recommendations for future emphases, } \\
\text { approaches or changes. } \\
\text { FIU and FSA/DCCA should regularly exchange pertinent } \\
\text { information that would support each others efforts, for instance } \\
\text { information on problems with the level or quality of STR } \\
\text { reporting by various financial sectors or specific institutions, or } \\
\text { information that might lead to supervisory authorities to target } \\
\text { specific institutions for review or support an outreach effort by } \\
\text { both authorities to a specific sector. } \\
\text { The FIU and FSA/DCCA should be involved in a coordinated } \\
\text { effort to ensure that all appropriate institutions and persons under } \\
\text { their supervision are receiving individual state provided lists and } \\
\text { handling them appropriately. }\end{array}$ \\
\hline The Conventions and UN Special & Denmark should adopt mechanisms to freeze all assets of terrorists \\
\hline
\end{tabular}




\begin{tabular}{|c|c|}
\hline Resolutions (R.35 \& SR.I) & $\begin{array}{l}\text { and terrorist organizations not only those that may be used for } \\
\text { terrorist purposes. } \\
\text { Legal framework and implementation in the Faroe Islands and } \\
\text { Greenland for all applicable convention obligations need to be put } \\
\text { in place, and conventions extended to these jurisdictions. }\end{array}$ \\
\hline $\begin{array}{l}\text { Mutual Legal Assistance (R.36, 37, } \\
\text { 38, SR.V \& 32) }\end{array}$ & $\begin{array}{l}\text { Denmark has not maintained the statistics necessary for it to fully } \\
\text { evaluate its mutual legal assistance program. Statistics gathering } \\
\text { and evaluation should be ongoing, and the program adopted } \\
\text { should address both requests sent and received directly by } \\
\text { executing authorities as well as those sent and received through } \\
\text { the MOJ channels. } \\
\text { Although Greenland and the Faroe Islands are able to request and } \\
\text { provide mutual legal assistance generally to parties to the } \\
\text { European Convention and under the principles of the Convention } \\
\text { to other states if a coercive measure is not involved, the narrower } \\
\text { scope of the ML and FT criminal provisions in Greenland and the } \\
\text { Faroe Islands (see Sections } 1.1 \text { and } 1.2 \text { above) may form an } \\
\text { obstacle to providing assistance involving coercive measures } \\
\text { because of an absence of dual criminality. In addition, tracing, } \\
\text { seizing and freezing and confiscation provisions should be } \\
\text { updated as is occurring so a full measure of assistance can be } \\
\text { provided. } \\
\text { Arrangements for incoming and outgoing requests relating to FT } \\
\text { should be enhanced to ensure all requests, including direct } \\
\text { requests (those issued directly from or to prosecutors/police } \\
\text { authorities), are channeled through SøK with the FIU is involved } \\
\text { and informed. } \\
\text { Denmark should consider providing mutual legal assistance when } \\
\text { the underlying conduct is still actionable in the requesting state but } \\
\text { time-barred within Denmark, and review whether it is possible to } \\
\text { lift the requirement of a Danish court order for production of } \\
\text { documents or provisional measures such as seizure (freezing or } \\
\text { seizing) prior to making an international request, particularly in } \\
\text { the context of fast moving proceeds or account records needed on } \\
\text { an immediate basis. }\end{array}$ \\
\hline Extradition (R. 39, 37, SR.V \& R.32) & $\begin{array}{l}\text { Denmark should maintain comprehensive statistics on incoming } \\
\text { and outgoing extradition requests including the nature of the } \\
\text { request, whether granted or refused and time required for } \\
\text { response. } \\
\text { In the case of Greenland and the Faroe Islands, the European } \\
\text { Convention on Extradition applies but there do not appear to be } \\
\text { treaties, conventions (as the Vienna, Palermo and Terrorist } \\
\text { Financing) or domestic laws and procedures that would permit } \\
\text { extradition in the case of other countries. In addition, as the } \\
\text { Terrorist Financing Convention does not extend to these } \\
\text { jurisdictions and there is not full criminalization of terrorist }\end{array}$ \\
\hline
\end{tabular}




\begin{tabular}{|l|l|}
\hline & $\begin{array}{l}\text { financing, possibilities for extradition for financing of terrorism- } \\
\text { related offences appear limited. Likewise, although ML is } \\
\text { criminalized in Greenland and the Faroe Islands, the } \\
\text { criminalization does not fully meet international standards and this } \\
\text { may pose dual criminality issues in an extradition context. } \\
\text { Authorities should put in place the legal and practical framework } \\
\text { by extending conventions to these jurisdictions which would } \\
\text { provide a legal basis for extradition, ensuring the criminalization } \\
\text { provisions meets Convention requirements and putting any } \\
\text { domestic provisions in place that are necessary for extradition to } \\
\text { occur. }\end{array}$ \\
\hline $\begin{array}{l}\text { Other Forms of Cooperation (R. 40, } \\
\text { SR.V \& R.32) }\end{array}$ & $\begin{array}{l}\text { There could be easier and direct access by the FIU to information } \\
\text { relevant to the analysis of a STR, which would enhance } \\
\text { cooperation with other FIUs, including administrative FIUs. }\end{array}$ \\
\hline 7. Other Issues & $\begin{array}{l}\text { Maintain more comprehensive statistics on law enforcement, FIU } \\
\text { and supervisory international cooperation. }\end{array}$ \\
\hline $\begin{array}{l}\text { Other relevant AML/CFT measures } \\
\text { or issues }\end{array}$ & \\
\hline
\end{tabular}


Authorities' Response to the Assessment 
Annex I. Details of all bodies met on the on-site mission - Ministries, other government authorities or bodies, private sector representatives and others.

\section{Ministries}

Ministry of Economic and Business Affairs

Ministry of Justice

Ministry of Foreign Affairs

Ministry of Taxation

Ministry of Social Affairs

\section{Operational, Law Enforcement and Intelligence Agencies}

The Office of the Public Prosecutor for Serious Economic Crime

Money Laundering Secretariat (FIU)

The Danish National Police

National Security Service

Copenhagen Police Department

Danish Security Intelligence Service

Serious and Organised Crime Agency

Central Customs and Tax Administration

\section{Supervisory Bodies}

Financial Supervisory Authority

The Commerce and Companies Agency

\section{Other Bodies}

The National Agency for Enterprise and Construction

Danmarks National Bank

National Audit Office of Denmark 


\section{Financial Institutions}

Danske Bank

Nordea

Nykredit

Lokalbanken

Danika Pension

AON, Insurance Brokers

F \& P, Forsikring \& Pension

Forsikringsmaeglernes

Western Union Money Transfer

Forex A/S

Foreign Exchange Bureau

Nordic Asset Management

\section{Professional Bodies}

\section{Financial}

The Danish Bankers Association

Danish Securities Dealers Association

The Danish Insurance Association.

The Association of Insurance Brokers

\section{Designated Non-Financial Businesses and Professions}

The Institute of State-Authorised Public Accountants

The Association of Licensed Accountants

The Danish Bar and Law Society

The Danish Association of Chartered Estate Agents

Casino Copenhagen

The Danish Jewellers Association 


\section{Other}

ISOBRO (umbrella organization for NPOs)

The Danish Council on Social Volunteering 


\section{Annex II. Copies of key laws, regulations and other measures}

Act on Measures to Prevent Money Laundering and Financing of Terrorism ${ }^{1)}$

Act no. 117 of 27 February 2006

Act no. 117 of 27 February 2006

We, Margrethe II, by the grace of God Queen of Denmark hereby make known:

Folketinget has adopted and We with Our consent hereby enact the following Act:

\section{Part 1}

Scope etc.

1.-(1) This Act shall apply to the following undertakings and persons:

19)Banks.

20) Mortgage-credit institutions.

21) Investment companies.

22) Investment management companies.

23) Life assurance companies and lateral pension funds (nationwide occupational pension funds).

24)Savings undertakings.

25) Electronic money institutions.

26) Insurance brokers, when they act in respect of life assurance or other investmentrelated insurance activities.

27) Foreign undertakings' branches in Denmark, carrying out activities under nos. 1-8.

28) Investment associations and special-purpose associations, collective investment schemes, restricted associations, innovation associations and hedge associations.

29) Undertakings and persons that commercially carry out activities involving currency exchange or transfer of money and other assets.

30) Other undertakings and persons that commercially carry out one or more of the activities mentioned in annex 1.

31) Lawyers when they participate by providing assistance in the planning or execution of transactions for their clients concerning

i) purchase and sale of real property or undertakings,

ii) managing their clients' money, securities, or other assets,

iii) opening or managing bank accounts, savings accounts, or securities accounts,

iv) raising the necessary capital for establishment, operation, or management of undertakings,

v) establishing, operating, or managing undertakings, or

vi) providing other business advice.

32) Lawyers when they, on behalf of their client and at said client's expense, carry out a 
financial transaction or a transaction concerning real property.

33) State-authorised public accountants and registered public accountants.

34) Authorised estate agents.

35) Undertakings and persons that otherwise commercially supply the same services as the groups of persons mentioned in nos. 13-16, including tax advisors and external accountants.

36) Providers of services for undertakings, cf. section 3, no. 5.

37) Danmarks Nationalbank (Denmark's central bank), insofar as it carries out activities corresponding to those of the institutions specified in no. 1.

(2) The Danish FSA may lay down regulations stipulating that this Act is not to apply to the undertakings or persons mentioned in subsection (1), nos. 1-12 in the situations where the Commission decides this pursuant to Article 40 of the Third Money Laundering Directive.

\section{Ban against cash transactions}

2. Retailers and auctioneers may not receive cash payments of DKK 100,000 or more irrespective of whether payment is effected in one instance or as several payments that seem to be mutually connected.

\section{Part 2}

\section{Definitions}

3. For the purposes of this Act:

1) "Companies" shall mean: Legal persons.

2) "Undertakings" shall mean: Companies and other similar legal arrangements.

3) "Regulated market" shall mean: A market as defined by Article 4(14) of Directive 2004/39/EC on markets in financial instruments. If said market is in the European Union or in a country with which the Community has entered into an agreement for the financial area, the market shall be included in the list mentioned in Article 47 of Directive 2004/39/EC on markets in financial instruments. If the market is in a country outside the European Union with which the Community has not entered into an agreement for the financial area, the market shall be a member of the World Federation of Exchanges (WFE).

4) "Beneficial owners" shall mean: The natural persons who ultimately own or control the customer or the natural person on whose behalf a transaction or activity is being conducted, including:

a) Persons who ultimately own or control a company through direct or indirect ownership or control more than 25 per cent of the ownership interests or the voting rights in the company, except companies the ownership interests of which are traded on a regulated market.

b) Person who otherwise exercise control over the management of a company.

c) Persons who, according to the articles of association of a fund or in another manner, are to receive 25 per cent or more of the distribution funds from a fund or another similar legal arrangement or other property, if the persons are known. 
d) The group of persons, in whose main interest a fund or another similar legal arrangement has been set up or operates.

e) Persons who exercise control over 25 per cent or more of the distribution funds from a fund or another similar legal arrangement or other property.

5) "Providers of services for undertakings" shall mean: Any person, legal or natural, that is not covered by section $1(1)$, nos. 13-15, when said person carries out the following activities on a commercial basis:

a) Forming companies.

b) Acting as or arranging for another person to act as a member of the management of an undertaking, or as partner of a partnership, or a similar position in relation to other companies.

c) Provides a domicile address or another address, which is similarly suitable as contact address and related services, for an undertaking.

d) Acting as or arranging for another person to act as a trustee or administrator of a fund or another similar legal arrangement.

e) Acting as or arranging for another person to act as a shareholder for a third party, unless this is an undertaking the ownership interests etc. of which are traded on a regulated market.

6) "Politically exposed persons" shall mean: Persons who are or have been entrusted with a prominent public function, persons connected to such persons through samesex partnership or marriage or the children or parents of such persons and persons known to be close employees of said persons.

4.-(1) For the purposes of this Act "money laundering" shall mean,

1) unlawfully to accept or acquire for oneself or others a share in profits, which are obtained by a punishable violation of the law,

2) unlawfully to conceal, keep, transport, assist in disposal or in a similar manner subsequently serve to ensure, for the benefit of another person, the profits of a punishable violation of the law, or

3) attempting or participating in such actions.

(2) The provision in subsection (1) shall also cover actions carried out by the person who committed the punishable violation of the law from which the profits originate.

5. For the purposes of this Act, "financing of terrorism" shall mean financing of terrorism as defined in section 114a of the Criminal Code.

\section{Part 3}

\section{Investigation and reporting obligations}

6.-(1) The undertakings and persons covered by this Act shall pay special attention to customers' activities which, by their nature, could be regarded as being particularly likely to be associated with money laundering or financing of terrorism. This applies in particular to complex or unusually large transactions and all unusual patterns of transactions in relation to said customer. 
(2) The purpose of the transactions mentioned in subsection (1) shall, as far as possible, be investigated. The results of such investigation shall be recorded and kept, cf. section 23.

7.-(1) If there is a suspicion that a customer's transaction or enquiry is or has been associated with money laundering or financing of terrorism, the undertakings and persons covered by this Act shall investigate the transaction or enquiry in more detail. If the suspicion relates to offences punishable by imprisonment of more than one year and this suspicion cannot be disproved, the Public Prosecutor for Serious Economic Crime shall be informed immediately.

(2) In the event of suspicion as mentioned in subsection (1), members of the Danish Bar and Law Society may notify the secretariat of the Danish Bar and Law Society, which shall, following an assessment of whether the suspicion is subject to reporting obligations under subsection (1), immediately forward the notification to the Public Prosecutor for Serious Economic Crime.

(3) If the suspicion is related to money laundering, and the transaction has not already been carried out, the transaction shall be suspended until notification has been effected pursuant to subsection (1). If notification is effected pursuant to subsection (2), the transaction shall be suspended until the Danish Bar and Law Society has forwarded the notification to the Public Prosecutor for Serious Economic Crime or has stated that, following specific assessment, the notification will not be forwarded. If effectuation of the transaction cannot be avoided, or if this is deemed to be potentially harmful for the investigation, notification shall instead be given immediately after the effectuation, cf. however subsection (4).

(4) If the suspicion is related to financing of terrorism, transactions from the account or person in question may only be carried out with the consent of the Public Prosecutor for Serious Economic Crime. The Public Prosecutor for Serious Economic Crime shall decide, as soon as possible and no later than at the end of the banking day following receipt of notification, whether seizure is to be effected.

(5) The Police may, under the regulations stipulated in the Administration of Justice Act, demand any information necessary for investigation of the case from the undertakings and persons covered by this Act.

8.-(1) Lawyers are exempted from the obligation in section 7 to report information they receive from or obtain about one of their clients, in the course of determining the legal position for their client or performing their task of defending or representing said client in, or concerning judicial proceedings, including advice on instituting or avoiding proceedings. This shall apply irrespective of whether the information is received before, during or after such judicial proceedings or in connection with the relevant client's legal position being ascertained.

(2) The persons and undertakings mentioned in section 1(1), nos. 13-17 shall, when assisting a lawyer before, during, and after judicial proceedings or in ascertaining a client's legal position, be exempt from the duty to submit information to the same extent as the lawyer they assist, cf. subsection (1).

(3) Subsections (1) and (2) shall also apply to cases brought before the Danish National 
Tax Tribunal and to cases brought before a court of arbitration. When representing clients before the Danish National Tax Tribunal, auditors shall also be exempt from the duty to submit information pursuant to this Act.

(4) Subsections (1) and (2) shall not apply if the assistance is provided with a view to money laundering or financing of terrorism, or if the undertaking or person knows that the client is seeking assistance with a view to money laundering or financing of terrorism.

9. If the Danish FSA or the Danish Commerce and Companies Agency learns of circumstances that are presumed to be associated with money laundering or financing of terrorism covered by the reporting obligation in section 7 , said authority shall notify the Public Prosecutor for serious economic crime in this respect.

10. The Danish FSA may, when acting on the recommendations of the Financial Action Task Force, lay down more specific regulations on the duty applying to the undertakings and persons specified in section 1 , requiring them to systematically submit information to the Public Prosecutor for serious economic crime concerning financial transactions with non-cooperative countries in connection with combating money laundering or financing of terrorism. In this connection, the Danish FSA may stipulate that notification is to be carried out systematically in all cases, even though no suspicion has arisen.

\section{Part 4}

Customer due diligence, etc.

11. The undertakings and persons covered by this Act shall always require that customers identify themselves, if they suspect that a transaction is associated with financing of terrorism or money laundering covered by the reporting obligation under section 7.

\section{Regular customer relationships}

12.-(1) The undertakings and persons covered by this Act shall have knowledge of their customers in accordance with subsections (2)-(8), and they shall require that their customers provide proof of identity when establishing a business relationship with said customers, including the opening of an account or a custody account.

(2) If the customer is a natural person, proof of identity shall include name, address, national registration number (CPR number) or similar documentation if the person in question does not have a CPR number.

(3) If the customer is an undertaking, the proof of identity shall include name, address, CVR number (business registration number) or similar documentation if the undertaking does not have a CVR number. Reasonable steps shall be taken to ascertain the undertaking's ownership and control structure and the undertaking's beneficial owners shall be identified, cf. however section 21(1), no. 2.

(4) Information shall be obtained about each customer's objective regarding the 
business relationship and the intended extent hereof.

(5) The customer relationship shall be monitored on a regular basis. Transactions undertaken throughout the course of said relationship shall be monitored to ensure that the transactions being conducted are consistent with the undertaking's or person's knowledge of the customer and the customer's business and risk profile, including, where necessary, the source of the funds. Documents, data or other information about the customer shall be kept up to date.

(6) In the event of doubts about the veracity or adequacy of previously obtained customer identification data, new proof of identity shall be required as mentioned in subsections (2) and (3).

(7) The undertakings and persons covered by this Act may decide to carry out the identification procedure etc. in subsections (1)-(5) on the basis of a risk assessment, depending on the risk related to the individual customer or business relation, the product or the transaction. The undertaking or person shall, however, be able to prove to the authority carrying out supervision of the relevant undertaking's or person's compliance with this Act that the extent of their investigation is adequate in relation to the risk of money laundering and financing of terrorism.

(8) For customer relationships established before entry into force of this Act and where the information mentioned in subsections (1)-(5) does not exist, proof of identity and collection of information under subsections (1)-(5) shall be carried out at a suitable time and on the basis of a risk assessment.

13.-(1) The identification procedure in section 12 shall be completed in connection with the establishment of the customer relationship and no later than before carrying out the transaction. Provided that it is necessary in order not to interrupt the normal conduct of business, the identification procedure may, on the basis of a risk assessment, be completed in immediate continuation of the establishment of the customer relationship. In the situations mentioned in the 2nd clause, the identification procedure shall, however, be completed as soon as practicable after the initial contact with the customer.

(2) If the proof of identity of the customer cannot be carried out in accordance with section 12(1)-(4), a regular customer relationship or a business relationship may not be established, and transactions may not be carried out for said customer. At the same time, the undertaking shall check whether notification under section 7 is to be carried out.

(3) Notwithstanding subsection (1), life-assurance companies and pension funds may carry out proof of identity of the customer after establishment of the customer relationship. Proof of identity shall, however, take place at or before the time of payout or at the time the beneficiary intends to exercise rights vested under the policy.

(4) Subsection (2), 1st clause shall not apply to lawyers when ascertaining a client's legal situation or defending or representing said client during or in connection with a judicial proceedings, including giving advice about instituting or avoiding proceedings. The persons and undertakings mentioned in section 1(1), nos. 13-17, shall, when assisting a lawyer in the situations mentioned in the 1st clause, be exempt from the requirement in subsection (2), 1st clause to the same extent as the lawyer they assist. 


\section{Occasional customers}

14.-(1) For customers with single transactions (occasional customers) undertakings and persons covered by this Act shall meet the requirements of section 12(1)-(4) and section 13 for each transaction of amounts corresponding to DKK 100,000 or more. The requirements concerning proof of identity shall apply irrespective of whether the transaction is completed in one or more related operations if these appear to be connected.

(2) If the value of a transaction is not known at the time of commencement of said transaction, proof of identity shall be demanded as soon as the undertaking suspects that the transaction concerned is of the type covered by subsection (1).

\section{Transactions for a third party}

15. If an undertaking or person covered by this Act has knowledge or presumption that a person other than the one they are in contact with is the beneficial customer, said undertaking or person shall also demand to be informed of the identity etc. of the beneficial customer in accordance with section 12 .

\section{Money transmission services}

16.-(1) Transactions of payments carried out without personal contact between sender and intermediary or by an intermediary with which the sender does not hold an account shall at all stages of the transaction be accompanied by information about the sender, cf. section 12(2) and (3), 1st clause. The intermediary shall ensure that the information about the sender is adequate and meaningful.

(2) The requirement for sender identification stipulated in subsection (1) shall not, however, apply to clearing and settlement systems carrying out payments between undertakings covered by section 1(1), nos. 1-12 or between corresponding undertakings within the European Union or a country with which the Community has entered into an agreement for the financial area, nor shall said requirement apply to systems for settlement of securities.

\section{Information from a third party}

17.-(1) The undertakings and persons covered by this Act may omit to obtain the information about a customer's identity etc. pursuant to section 12(1)-(4) when this information is provided by an insurance broker, cf. section 2, no. 1 of the Insurance Mediation Act; a financial undertaking, cf. section 5, no. 1 of the Financial Business Act; or by a foreign undertaking that has been granted a license to carry out the activities mentioned in sections 7-11 of the Financial Business Act in a country within the European Union or in a country with which the Community has entered into an agreement for the financial area. Notwithstanding the 1st clause, the recipient undertaking or person shall be responsible for meeting the requirements of section 
12(1)-(4)

(2) If the undertaking providing the information mentioned in subsection (1) has been granted a license to carry out the activities mentioned in sections 7-11 of the Financial Business Act in a country outside the European Union with which the Community has not entered into an agreement for the financial area, undertakings and persons covered by this Act may apply information obtained by the relevant undertaking as a basis if said undertaking is subject to requirements about the fight against money laundering and financing of terrorism similar to the requirements of the Third Money Laundering Directive, and if compliance with said requirements is being checked.

(3) Subsection (1) shall not apply to matters in the undertakings mentioned in subsection (2) if the European Commission decides under Article 40(4) of the Third Money Laundering Directive to exempt the country where the relevant undertaking has its registered office.

18. The undertaking providing information about a customer's identity etc. pursuant to section 17 shall immediately make this information available to the recipient undertaking or person covered by this Act. Moreover, the undertaking shall, at the request of the recipient undertaking or person, immediately send relevant proof of identity and control information as well as other relevant documentation on the identity of the customer or the beneficial owner.

Enhanced customer due diligence etc.

19.-(1) The undertakings and persons covered by this Act shall, on the basis of a risk assessment, make further requirements for proof of identity by a customer than mentioned in section 12 in situations which by their nature can present a higher risk of money laundering and financing of terrorism. This means that they, as a minimum, shall meet the requirements in subsections (2)-(4).

(2) When the customer has not been physically present for identification purposes, the undertaking or person shall take further measures to ascertain the customer's identity. This may be effected, for example, by taking one or more of the following measures:

1) Ensuring that the customer's identity is established by additional documentation.

2) Checking or verifying the documents supplied, or requiring confirmatory certification by one of the undertakings or persons mentioned in section 1(1), nos. 1-11.

3) Requiring that the first payment in connection with the transactions is carried out through an account opened in the customer's name with a bank.

(3) For cross-frontier correspondent banking relationships with banks and institutions from countries outside the European Union with which the Community has not entered into an agreement for the financial area, the banks, mortgage-credit institutions and electronic money institutions covered by this Act shall, before establishing new correspondent banking relationships,

1) gather sufficient information about a respondent institution to understand fully the nature of the respondent's business and to determine from publicly available 
information the reputation of the institution and the quality of supervision,

2) assess the counterparty's anti-money-laundering and anti-terrorist-financing controls,

3) obtain approval from senior daily management, and

4) ensure that the respondent bank has checked the identity of the customers and is regularly assessing relevant information about the customers having direct access to the account of the correspondent bank with a person or undertaking covered by this Act, and ensure that the respondent bank is able to supply relevant customer information at the request of the account holder.

(4) The undertakings and persons covered by this Act shall

1) have adequate procedures to determine whether the customer is a politically exposed person who is a resident of another country,

2) have senior daily management approval for establishing business relationships with such customers,

3) take reasonable measures to gather information about the sources of income and funds that are involved in the business relationship or transaction, and

4) continuously monitor the business relationship.

(5) Banks, mortgage-credit institutions and electronic money institutions may not enter into or continue a correspondent banking relationship with a shell bank and they shall take reasonable measures to avoid a connection with a credit institution which is known to permit shell banks to use its accounts.

(6) Undertakings and persons covered by this Act shall be particularly aware of any money laundering and financing of terrorism threats that may arise from products or transactions that might favour anonymity, and take measures, if needed, to prevent that the products or transactions are used for money laundering and financing of terrorism purposes.

Simplified customer due diligence, etc.

20-(1) The requirement concerning proof of identity in sections 12 and 19(2) may be omitted with regard to the following products and transactions:

1) Life-assurance and pension contracts if the amount of the annual premium is equivalent to EUR 1,000 or less or, in the case of a single premium, if the amount of the single premium is equivalent to EUR 2,500 or less.

2) Life-assurance and pension contracts entered into in pursuance of a contract of employment or the business of the insured party, provided the agreement does not feature a buy-back clause and cannot be used as collateral for a loan.

3) Life-assurance and pension contracts where the premium or the contribution is to be debited to the customer's bank account.

4) Life-assurance and pension contracts entered into in pursuance of a contract of employment or the business of the insured party with a limited buy-back clause, when proof of identity is given pursuant to section 12 if the customer makes use of the buy-back clause.

5) Electronic money, as defined in section 308(1), 2nd and 3rd clauses of the Financial 
Business Act

a) where the maximum amount stored on non-rechargeable cards cannot exceed EUR 150, or

b) where the maximum amount stored on rechargeable cards cannot exceed EUR 2,500 within one calendar year, and where a maximum of EUR 1,000 can be withdrawn within one calendar year.

(2) Irrespective of the size of the transaction or the nature of the product, undertakings shall demand proof of identity if they suspect that the transaction is associated with money laundering or financing of terrorism covered by the reporting obligations under section 7.

(3) The Danish FSA may, on the basis of decisions from the European Commission, lay down regulations allowing other products or transactions to be exempted.

21.-(1) The requirements concerning proof of identity in section 12 shall not apply when the customer is

1) one of the undertakings mentioned in section 1(1), nos. 1-11 and 19 or a similar undertaking with its registered office in a country within the European Union or a country with which the Community has entered into an agreement for the financial area covered by the Third Money Laundering Directive, or a similar undertaking established in a country outside the European Union with which the Community has not entered into an agreement for the financial area, subject to requirements to combat money laundering and financing of terrorism corresponding to the requirements stipulated in the Third Money Laundering Directive, and if compliance with these requirements is supervised,

2) an undertaking the securities of which have been admitted to trading on a regulated market, or

3) a Danish public authority.

(2) The requirements concerning proof of identity in section 12 shall not apply when the beneficial owner has funds in a client's account of a notary or a lawyer, if the notary or the lawyer is subject to regulations corresponding to this Act. It is a condition that information about the identity of the beneficial owner etc. is made available to the account-holding institution when said institution requests this.

(3) At all events, sufficient information shall be obtained to ascertain that the customer is covered by one of the exemptions mentioned in subsections (1) and (2).

(4) The Danish FSA may, on the basis of decisions by the European Commission, lay down regulations allowing other undertakings and persons to be exempted.

22. If the European Commission so decides, the Danish FSA may decide that persons and undertakings covered by this Act are not to apply the exemption in section 21 in relation to credit institutions and finance institutions or listed undertakings or other units from a country outside the European Union with which the Community has not entered into an agreement for the financial area. 
Record-keeping, etc.

23.-(1) The undertakings and persons covered by this Act shall store identity information for no less than five years after the customer relationship has ceased. Copies of the identification documents obtained pursuant to sections 12, 14, 18 and 19 may be stored.

(2) Documents and records concerning transactions shall be stored so that they can be located together for at least five years after the performance of the transactions. This shall also apply to the information recorded pursuant to section 6(2).

(3) If the undertaking ceases activities, the last acting management shall ensure that identity information etc. continues to be stored in accordance with subsections (1) and (2). If an undertaking is dissolved through the intervention of the bankruptcy court, the bankruptcy court may decide that persons other than the last acting management are to store the identity information etc.

\section{Branches and subsidiary undertakings in third countries}

24.-(1) The undertakings covered by section $1(1)$, nos. 1-7 and 10-12 shall ensure that their branches and subsidiary undertakings established in countries outside the European Union with which the Community has not entered into an agreement for the financial area have customer due diligence measures and storage of identity information etc. corresponding to the requirement of the Third Money Laundering Directive, to the extent that the legislation of said country allows this.

(2) If the legislation in the country mentioned in subsection (1) does not permit the use of measures similar to those mentioned in subsection (1), the undertaking shall inform the authority supervising the undertaking's compliance with this Act, cf. part 8 of this Act. The undertaking shall also ensure that the threat of money laundering and financing of terrorism in the branch or the subsidiary undertaking is countered in another manner.

(3) The undertakings mentioned in subsection (1) shall ensure that their branches and subsidiary undertakings established in countries outside the European Union with which the Community has not entered into an agreement for the financial area have written internal rules regarding customer due diligence and record-keeping corresponding to the requirements in section $25(1)$ to the extent that the legislation of said country allows this.

\section{Part 5}

Internal rules and training etc.

25.-(1) The undertakings and persons covered by this Act shall prepare adequate written internal rules about customer due diligence, reporting, record-keeping, internal control, risk assessment, risk management, management controls and communication as well as training and instruction programmes for their employees in order to forestall and prevent money laundering and financing of terrorism. 
(2) Undertakings and persons covered by section 1(1), nos. 1-10 shall appoint a person at management level to ensure that the undertaking complies with its obligations under this Act.

(3) Undertakings and persons covered by section 1 shall ensure that their employees know of the obligations stipulated in this Act.

(4) In employment relationships, the obligations mentioned in subsections (1) and (2) shall rest on the employer.

(5) The Danish FSA may lay down more detailed regulations on the requirements mentioned in subsection (1).

\section{Part 6}

\section{Duty of confidentiality and liability}

26. The notifications and information that undertakings and persons covered by this Act disclose in good faith pursuant to section 7 and suspension of transactions pursuant to section 7(4) shall not incur any liability on the undertaking or person, its employees or management. Disclosure of information in connection with this shall not be considered a breach of any duty of confidentiality.

27.-(1) Undertakings and persons covered by this Act, management and employees in said undertakings and employees of said persons as well as auditors or other persons carrying out or having carried out special tasks for the undertaking or person shall be obliged to keep secret the fact that notification has been effected under section 7 , that this is being considered, or that an investigation of whether this is a case of money laundering or financing of terrorism has been or will be instigated, cf. however subsections (2)-(6).

(2) Information that notification has been effected under section 7, that this is being considered, or that an investigation of whether this is a case of money laundering or financing of terrorism has been or will be instigated may be divulged to the authorities and organisations that supervise compliance with this Act.

(3) The prohibition laid down in subsection (1) shall not prevent lawyers, auditors, external accountants and tax advisors from discouraging their client from carrying out illegal activities.

(4) Information that notification has been effected under section 7, that this is being considered, or that an investigation of whether this is a case of money laundering or financing of terrorism has been or will be instigated may be divulged to undertakings belonging to the same group as defined by Article 2(12) of Directive 2002/87/EC.

(5) Information that notification has been effected under section 7, that this is being considered, or that an investigation of whether this is a case of money laundering or financing of terrorism has been or will be instigated may be divulged between persons as mentioned in section 1(1), nos. 13-15 if both the person divulging the information and the person receiving the information carry out their activities within the same legal 
unit or network.

(6) Information that notification has been effected under section 7, that this is being considered, or that an investigation of whether this is a case of money laundering or financing of terrorism has been or will be instigated may be divulged between persons or undertakings covered by section $1(1)$, nos. 1-14 provided

1) that the information relates to an undertaking or person that is a customer of both the undertaking or person divulging the information and the undertaking or person receiving the information, and that the information relates to a transaction involving both parties,

2 ) that the undertaking or person divulging the information and the undertaking or person receiving the information have the same occupation,

3 ) that the undertaking or person divulging the information and the undertaking or person receiving the information are subject to uniform requirements as regards duty of confidentiality and protection of personal data, and

4) that the information exchanged is only applied for prevention of money laundering and financing of terrorism.

(7) Information as mentioned in subsections (4)-(6) may only be divulged to undertakings and persons that have their registered offices or are domiciled in a country outside the European Union with which the Community has not entered into an agreement for the financial area, if the undertaking or person is subject to requirements to combat money laundering and financing of terrorism corresponding to the requirements stipulated in the Third Money Laundering Directive and that compliance with these requirements is being supervised.

28. The Danish FSA shall inform the other Member States and the European Commission of matters where it decides that a country outside the European Union with which the Community has not entered into an agreement for the financial area does have requirements to combat money laundering and financing of terrorism corresponding to the requirements stipulated in the Third Money Laundering Directive and that compliance with these requirements is being supervised.

29. If the European Commission so decides, the Danish FSA may decide that undertakings and persons covered by this Act are not to divulge information to countries outside the European Union with which the Community has not entered into an agreement for the financial area pursuant to section 27.

\section{Part 7}

\section{Counterfeit money}

30. Undertakings and persons that, as part of their activities, take part in handling and delivery of notes and coins to the general public, including persons and undertakings the activity of which consists of exchanging notes and coins of various currencies, shall remove from circulation all notes and coins that they know or have reason to believe are counterfeit. Counterfeit banknotes and coins shall be submitted to the Police immediately. 


\section{Part 8}

Registration and supervision etc.

31.-(1) Persons and undertakings covered by section 1(1), nos. 11 and 18 shall be registered with the Danish Commerce and Companies Agency in order to carry out such activities.

(2) The Danish Commerce and Companies Agency shall refuse to register the persons and undertakings mentioned in subsection (1) if the persons or members of management mentioned or the beneficial owners of the undertaking have been convicted of a criminal offence and such offence gives reason to believe that there is an immediate danger that the position or business may be abused, cf. section 78(2) of the Criminal Code.

(3) The Danish Commerce and Companies Agency shall deregister a person or undertaking mentioned in subsection (1) if a registered person or a member of management or the beneficial owners of a registered undertaking do not comply with the requirement in subsection (2).

32.-(1) The Danish Commerce and Companies Agency shall ensure that undertakings and persons covered by section 1(1), nos. 11 and 15-18 comply with this Act and the regulations issued pursuant hereto.

(2) Supervision under subsection (1) of undertakings and persons covered by section $1(1)$, nos. 15-18 shall be carried out on the basis of an assessment of the risk of money laundering and financing of terrorism.

(3) The undertakings and persons mentioned in subsection (1) shall provide the Danish Commerce and Companies Agency with all information necessary for supervision of compliance with this Act or regulations issued pursuant hereto.

(4) The Danish Commerce and Companies Agency may at all times, on proof of identity and without a court order, gain access to undertakings and persons covered by section $1(1)$, no. 11 with a view to obtaining information, including during inspections.

(5) The Danish Commerce and Companies Agency may use external assistance in supervision under subsection (1).

33. The Danish Commerce and Companies Agency may, for the undertakings and persons mentioned in section 31, lay down more detailed regulations regarding notification, registration and public disclosure, including regulations stipulating which information is to be registered and which matters applicants or others may submit and register electronically themselves in the Agency's computer system by using a digital or similar electronic signature, and regarding the use of such a system.

34.-(1) The Danish FSA shall ensure that undertakings and persons covered by section $1(1)$, nos. $1-10$ and 12 of this Act comply with this Act and the regulations issued pursuant hereto. 
(2) Persons and undertakings covered by section $1(1)$, no. 12 shall be registered with the Danish FSA.

(3) The undertakings and persons mentioned in subsection (1) shall provide the Danish FSA with the information necessary for supervision of compliance with this Act or regulations issued pursuant hereto.

(4) The Danish FSA may at all times, on proof of identity and without a court order, gain access to undertakings and persons covered by subsection (1) with a view to gathering information, including during inspections.

(5) The Danish FSA may order that proof of identity and collection of information be effected in accordance with section 12(8).

\section{Feedback}

35.-(1) The Public Prosecutor for Serious Economic Crime may, if investigative considerations do not contradict this, inform the notifying person about the status of the matter, including whether a charge has been made, and may inform about deletion from the money laundering register at the Public Prosecutor for Serious Economic Crime, and about a final decision, on conviction possibly in the form of a judgment or a transcript of a judgment.

(2) The notifications mentioned in subsection (1) may not unlawfully be divulged to others.

\section{Part 10}

\section{Provisions regarding appeals}

36. Decisions made by the Danish FSA or the Danish Commerce and Companies Agency under this Act or regulations issued pursuant to this Act may be brought before the Company Appeals Board by the person against whom said decision is directed no later than four weeks after the person concerned has been notified about the decision.

\section{Part 11}

\section{Penalties}

37.-(1) Intentional or grossly negligent violation of section 2 ; section $6(2)$, 2nd clause; section 7(1), 2nd clause, (3) and (4), 1st clause; section 11; section 12(1)-(6); section $13(1), 1$ st and 3rd clauses, (2) and (3), 2nd clause; section 14; section 15; section 16(1); section 19(1), (2), 1st clause and (3)-(5); section 23(1), 1st clause, (2) and (3), 1 st clause; section 24; section 25(1)-(3); section 27(1); section 30, 2nd clause; section $31(1)$; section 32(3); and section 34(2) and (3) shall be subject to a fine. Intentional or grossly negligent violation of section 35(2) shall be subject to a fine, unless more severe 
punishment is incurred under the regulations of the Criminal Code.

(2) In the event of particularly gross or extensive intentional violations of section 2; section 7(1), 2nd clause, (3) and (4), 1st clause; section 12(1)-(6); sections 14, 15 and $16(1)$; and section 23(1), 1st clause, (2) and (3), 1st clause, the penalty may be increased to imprisonment of up to six months.

(3) In regulations issued by the Danish FSA or the Danish Commerce and Companies Agency pursuant to sections 10 and 33, fines may be stipulated for intentional or grossly negligent violation of the provisions of said regulations.

(4) If a person or undertaking omits to fulfil the duties and obligations imposed on them pursuant to section 32(3) and section 34(3), the Danish Commerce and Companies Agency and the Danish FSA respectively may, as a coercive measure, impose daily or weekly fines on the person, or undertaking or on the persons responsible for said undertaking.

(5) Any person or undertaking failing to comply with an order issued pursuant to section 34(5) shall be liable to a fine.

(6) Companies, etc. (legal persons) may incur criminal liability according to the regulations in chapter 5 of the Criminal Code.

\section{Part 12}

Entry into force and transitional provisions, etc.

38.-(1) This Act shall enter into force on 1 March 2006, cf. however subsection (3).

(2) At the same time, the Act on Measures to Prevent Money Laundering and Financing of Terrorism, cf. Consolidated Act no. 132 of 1 March 2005 shall be repealed.

(3) Section 6(2), section 12(5) and section 19 shall enter into force on 1 January 2007.

39. The provisions of section $31(2)$ and (3) shall not apply to undertakings and persons carrying out activities covered by section 1(1), nos. 11 and 18 on the date of entry into force of this Act.

40. The "lov om visse betalingsmidler" (act on certain means of payment), cf. Consolidated Act no. 1501 of 20 December 2004, as amended most recently by Act no. 603 of 24 June 2005 shall be amended as follows:

1. In section 10 , the following shall be inserted as subsection (2):

"(2) The obligation to receive cash payment under subsection (1) shall not apply to retailers and auctioneers in the event of cash payments of DKK 100,000 or more and payment is effected in one instance or as several payments that seem to be mutually connected." 
41. This Act shall not extend to Greenland and the Faeroe Islands, but may be brought into force by Royal Decree for these parts of the Realm subject to any variations in their operation necessitated by the specific conditions prevailing in Greenland and the Faeroe Islands respectively 


\title{
Annex 1
}

1) Acceptance of deposits and other repayable funds.

2) Lending, including

- consumer credit,

- mortgage-credit loans,

- factoring and discounting,

- financing of commercial transactions (including forfeiting).

3) Financial leasing.

4) Payment services (money transmission services).

5) Issue and administration of means of payment (e.g. credit cards, travellers' cheques, and bankers' drafts).

6) Guarantees and collateralisation.

7) Trading for own account or for account of customers in:

a) money market instruments (cheques, bills, certificates of deposit, etc.)

b) the foreign exchange market

c) financial futures and options

d) currency and interest rate instruments, and

e) securities.

8) Participation in issuing securities and provision of related services.

9) Advice to undertakings on capital structure, industrial strategy and related questions and advice, and services relating to mergers and the acquisition of undertakings.

10) Money broking.

11) Portfolio management and advice.

12) Safekeeping and administration of securities.

13) Safe custody services.

Christiansborg Slot, 27 February 2006

Under Our Royal Hand and Seal

In the Name of the Queen:

FREDERIK

Crown Prince

/Bendt Bendtsen

\begin{abstract}
Official notes
1) This Act contains provisions implementing parts of European Parliament and Council Directive (2005/60/EC) of 26 October 2005 on the prevention of the use of the financial system for the purpose of money laundering and terrorist financing (Official Journal 2005, L 309, p. 15). The Act includes certain provisions from Council Regulation no. $1338 / 2001$ of 28 June 2001 laying down measures necessary for the protection of the euro against counterfeiting, (Official Journal 2001, L 181, p. 6) and Council Regulation no. 1339/2001 of 28 June 2001 extending the effects of Regulation no. 1338/2001 laying down measures necessary for the protection of the euro against counterfeiting to those Member States which have not adopted the euro as their single currency, (Official
\end{abstract}


Journal 2001, L 181, p. 11). According to Article 249 of the EC Treaty, a Regulation applies immediately in each Member State. The reproduction of these provisions in this Act is thus only due to practical considerations and does not affect the immediate validity of the Regulations in Denmark.

Links to EC directives, cf. note 1

Directive 2005/60/EC Celex no. 32005L0060 


\section{Annex III: List of all laws, regulations and other material received}

\section{A. Laws on Money Laundering and the Financing of Terrorism}

1. The Act on Measures to Prevent Money Laundering and the Financing of Terrorism, (Money Laundering Act), March 2006

2. The Act on Measures to Prevent Money Laundering and the Financing of Terrorism, Consolidated Act. No. 132 of 1 March 2005

\section{B. Other Laws related to $\mathrm{ML} / \mathrm{FT}$}

3. The Foundation Act

4. The Foundation Tax Act

5. The Commercial Foundation Act

6. The Danish Act relating to the Takeover of Affairs and Fields of affairs by the Faeroe Islands Public Authorities, 2005

7. The Home Rule Act of the Faeroe Islands, 1948

8. Act No. 1383 of 20 December 2004 amending the Financial Business Act, the Act on Measures to Prevent Money laundering amd the Financing of terrorism

9. The Customs Act, (Extracts)

10.The Financial Business Act, cf. Consolidated Act No. 90 of 3 Febuary 2005, with amendments consequential upon section 2 of Act no. 387 of 30 May 2005, section 2 of Act no. 411 of 1 June 2005 and section 84 of Act no. 431 of 6 June 2005 (Extracts)

11.The Insurance Mediation Act

12. The Investment Associations and special Purpose Associations as well as other Collective Investment Schemes Act

13. The Securities Trading etc. Act

14. The Criminal Code (Extracts)

15. The Administration of Justice Act (Extracts) 
16. The Gambling Casino Act, as amended by Act no. 366 of may 24, 2005, and Act No. 443 of May 31, 2000

17. The Public Collections and Pyramid Gambling Act (Extracts)

18. Order on Public Collections (Extracts)

19. the Act on Processing of Personal Data (Extracts)

20. The Public Administration Act (Extracts)

21. The Securities Trading, etc Act (Extracts)

22. The Trade Marks Act (Extracts)

23. The Danish Act on the Central Business Register, Act No. 417 of $22^{\text {nd }}$ May 1996

24. Law No.433 of 10 June 2003, amending the Law on Extradition of offenders and the law on the Extradition of offenders to Finland, Iceland, Norway and Sweden

25. The Danish Private Companies Act, Consolidation Act No. 325 of 7 May 2000.

26. Act of June 6, 2002, No. 378, on amendments to the Danish Criminal Code, Danish Administration of justice act, Act on Competition and Consumer matters in the Telecommunication Market, the Weapons Act, the Extradition Act

27. Consolidated Act of August 25, 2005, No. 833, on the Extradition of Criminals

28. The Danish Act on International Enforcement of Criminal judgments, Consolidated Act of 18 july, 2005, No. 740

29. Home Rule Act of the Faroe Islands, No. 137 of March $23^{\text {rd }}, 1948$

30.Consolidated Act no. 613 of 21 June 2005 on the reorganisation and winding-up of insurance undertakings

31. Collective Investment Schemes etc Act

\section{Other Legislative Instruments-Decrees, Orders}

32. Directive 2005/60/EC of the European Parliament and the Council- 26 October 2005

33. Explanatory Notes to the Proposal for Act on Measures to prevent Money Laundering and the Financing of terrorism 
34. Legal Notice No. 496 of June 13, 1994, on Gambling Casinos, as amended by Notice No. 248 of april 4, 2000, and Notice No. 997 of december 9, 2002.

35. Order on Gambling Casinos

36. Proposal for a Regulation on information on the payer accompanying transfer of funds

37. Circular Letter from Ministry of Justice, 30 June 1993

38. Circular Letter from Ministry of Justice, 7 March 2005

39. Directive 2005/60/EC of the European and of the Council, of 26 October 2005, on the prevention of the use of the financial system for the purpose of money laundering and terrorist financing.

40. Note on The Faeroe Islands Home Rule Arrangement

41. Note on The Greenland Home Rule Arrangement

42. Note on Replies to Questions Asked by the Danish Financial Supervisory Authority in Connection with the IMF's Ongoing Examination of denmark

43. The Ministry of Justice: Circular Letter to the Police and the prosecution, 30 June 1993

44. Circular Letter from Ministry of Justice, 7 March 2005

\section{Other documents communicated}

45. Comments from the Ministry of Justice on the first Draft Detailed Assessment Report on Anti-Money Laundering and the Combating the Financing of Terrorism

(received on 16 March 2006).

46. Comments received by FATF on cooperation with Denmark on extradition, mutual legal assistance

47. Statistics 2005-Compulsory STRs, including ID hits, seizures, STRs investigated

48. Nykredit- Prevention of Money laundering and financing of terrorism

49. Guidelines on combating money laundering and terrorist financing

50. IMF Assessment: Anti-Money Laundering and Combating the Financing of Terrorism 6 March 2006- The Audit Profession 
51. Lovbekendtgorelse 1994-10-10 nr.861 om spillekasinoer: Hvidvaskning af penge, Skaaerpede kontrolbestemmelser

52. The DCCA: Aspects of the work with the MLA

53. Justitsministeriet, Lovafdelingen: Criminal Code, Part 10.

54. Erhvervs-OG- Selskabsstyrelsen: On-site Inspections: Face-to-face to the customer service

55. Social Ministeriet: Grant from the Grant Programme for Development of Voluntary Social Work (PUF), 23 Febuary 2006

56.Justitsministeriet, Answers to questions asked Febuary 13, 2006

57. Course in Economic Crime

58. Justitsministeriet, Criminal Code, Faroe Islands

59. Justitsministeriet, Extension of the scheme in the Self Assessment Report, p 29

60. Bekaempelse af terrorfinansiering og hvidvask af penge

61.Greenland-Introduction

62. Regulation of the European Parliament and of the Council on information on the payer accompanyying transfers of funds, 25 November 2005

63. Finanstilsynet: History of the FSA

64. Finanstilsynet: Collective Investment Schemes

65. Finanstilsynet: Mortgage Banks and Investment Companies Division

66.Detailed Assessment Questionnaire: Anti-Money Laundering and Combating the financing of terrorism, December 2005

67. RIGSPOLITET, Organised Crime in Denmark in 2004

68. Explanatory Notes to the Proposal for Act on Measures to prevent Money Laundering and Financing of Terrorism (Money laundering Act)

69. Guidelines issued by the Bankers Association 
70. The Investment Association and Special-Purpose Associations

71. Comments by the Danish authorities on chapters in the first draft, on Cross Border transactions, FIU.

72. Overview of information concerning the Danish NPO sector

73. Requirements concerning NPO's

74. Special Requirements for NPO's with commercial activities, tax exemptions, public collections, or public grants.

75. Answers from TAX to the questions sent 14 March 2006

76. Checklist on Money Laundering

77. Legislation against money laundering and financing of terrorism

78. Comments: Supplementary Document Request- Evaluation team Comment

79. Answers to comments: Supplementary Request

80. Your Contribution could end up in the Wrong Hands

81. Justttsministeriet, The Anti-Terrorism Act of the Ministry of Justice: elements, 12.Dec. 2001

82. Inspection on Site, Measures against Money Laundering, December 2004

83. The Money Laundering Secretariat, Annual Report 2004, Public Prosecutor for Serious Economic Crime.

84. Self-Assessment Questionnaire: FATF Special Recommendations on Terrorist Financing

85. VEJLEDNING for advokater og advokafirmaer om forebyggende foranstaltninger mod hvidvaskning af penge og finansiering af terrorisme 


\section{Money Laundering \\ Extract of DANISH CRIMINAL CODE \\ Unofficial Translation April, 2006}

Chapter 28

Property Offences

Section 290. (I) Any person who unlawfully accepts or acquires for himself or others a share in profits, which are obtained by a punishable violation of the law, and any person who unlawfully by concealing, keeping, transporting, assisting in disposal or in a similar manner subsequently serves to ensure, for the benefit of another person, the profits of a punishable violation of the law, shall be guilty of receiving of stolen goods and liable to a fine or imprisonment for any term not exceeding one year and six months.

(2) When the receiving of stolen goods is of a particularly aggravated nature, especially because of the commercial character of the offence, or in consequence of the amount of the gain obtained or intended to be obtained, or where a large number of offences have been committed, the penalty may be increased to imprisonment for any term not exceeding six years.

(3) Punishment pursuant to this provision can not be imposed on a person, who accepts profits as an ordinary subsistence from family members or cohabiter, or any person who accepts profits as a normal payment for ordinary consumer goods, articles for everyday use, or services. 


\title{
Financing of Terrorism
}

\author{
Extract of DANISH CRIMINAL CODE \\ Unofficial Translation April, 2006 \\ Chapter 13
}

Offences Against the Constitution and the Supreme Authorities of the State etc.

Section 114. (1) Any person is liable to imprisonment for any term up to life imprisonment if he commits one or more of the following offences with the intent seriously to intimidate a population or unlawfully to compel Danish or foreign public authorities or an international organisation to do or to abstain from doing any act or to destabilise or destroy the fundamental political, constitutional, economic or social structures of a country or an international organisation, provided that the offence may inflict serious harm on a country or an international organisation by virtue of its nature or the context in which it is committed:

1) Homicide under Section 237.

2) Assault under Section 245 or 246.

3) Deprivation of liberty under Section 261.

4) Impairment of the safe operation of means of transport under Section 184 (1), unlawful disturbances in the operation of public means of communication, etc., under Section 193 (1) or very serious damage to property under Section 291 (2), where such offences are committed in a manner likely to endanger human lives or cause considerable economic loss.

5) Unlawful seizure of public means of transport under Section 183a.

6) Serious violations of the arms legislation under Section 192a or under Section 10 (2) of the Act on Weapons and Explosives.

7) Arson under Section 180, explosion, spreading of noxious gases, floods, shipwreck or any railway or other traffic accident under Section 183 (1) and (2), injurious pollution of the water supply under Section 186 (1), injurious poisoning or pollution of products intended for general use, etc., under Section 187 (1).

(2) The same penalty shall apply to any person who transports weapons or explosives with the intent as referred to in Subsection (1) hereof.

(3) The same penalty shall also apply to any person who threatens to commit one of the offences listed in Subsections (1) and (2) hereof with the intent as referred to in Subsection (1) hereof.

Section 114a. Any person is liable to imprisonment for any term not exceeding 10 years if he:

1) directly or indirectly grants financial support to;

2) directly of indirectly provides or collects funds for; or

3) directly of indirectly makes money, other financial assets or financial or other similar services available to

a person, a group of persons or an association that commits or intends to commit terrorist acts comprised by Section 114.

Section 114b. Any person is liable to imprisonment for any term not exceeding six years if he otherwise contributes by instigation, advice or action to furthering the criminal activity or the common purpose of a group of persons or an association which commits one or more of the offences comprised by Section 114 or Section $114 a$, no. 1) or 2), where such activity or purpose involves the commission of one or more offences of such nature.

Section 114c. Any person who, by any act other than those included under Sections 114-114b of this Act, participates in or provides significant financial support or other significant support to any corps, group or association, which intends, by use of force, to exert influence on public affairs or give rise to disturbances of the public order, shall be liable to imprisonment for any term not exceeding six years. 
Section 114d. Any person who, by any act other than those included under Sections $114-114 \mathrm{c}$ of this Act, participates in an unlawful military organization or group, shall be liable to a fine or to imprisonment for any term not exceeding two years.

Section 114e. Any person who under aggravating circumstances in contravention of the legislation on non proliferation of weapons of mass destruction etc.

1) exports products with dual use without permission;

2) for the use by the authorities in making decisions about products with dual use gives incorrect or misleading information or suppresses information of significance for the decision in the case; or

3) acts in violation of conditions, which are stipulated in the authorities' decisions about products with dual use;

shall be liable to imprisonment for any term not exceeding six years.

Section 118a. The offences referred to in Sections 111-115 and 118 of this Act shall in all cases be dealt with by public prosecution, to be instituted by the order of the Minister of Justice. 


\title{
Seizure and Confiscation
}

\section{Extract of DANISH CRIMINAL CODE Unofficial Translation April, 2006}

\author{
Chapter 9 \\ Other legal Consequences of a Punishable Act
}

Section 75. (1) The proceeds gained from any criminal act, or a sum equivalent thereto, may, either wholly or in part, be confiscated. Where the size of such an amount has not been sufficiently established, a sum thought to be equivalent to the proceeds may be confiscated.

(2) The following objects may also be confiscated where this must be regarded as necessary in order to prevent further offences, or if warranted by special circumstances:

1) objects which have been used, or were intended to be used, in a criminal act;

2) objects produced by a criminal act; and

3 ) objects with respect to which a criminal act has otherwise been committed.

(3) In place of confiscation of the objects referred to in Subsection (2) above, a sum may instead be confiscated which is equivalent to their value or a part thereof.

(4) In place of confiscation under Subsection (2) above, arrangements concerning the objects may instead be decided upon for the purpose of preventing further offences.

(5) When an association is dissolved by judgment, its capital, documents, protocols etc. may be confiscated.

Section 76 (1) Confiscation under Section 75 (1) of this Act may be from any person to whom the proceeds of a criminal act have directly passed.

(2) Confiscation of the objects and amounts referred to in Section 75 (2) and (3) of this Act may be from any person who is responsible for the offence and also from someone on whose behalf such a person has acted.

(3) Specially protected rights over confiscated objects lapse only after the court's decision under circumstances similar to those referred to in Subsection (2) above.

(4) Where one of the persons referred to in Subsections (1) and (2) above has, after the criminal act, disposed of the proceeds or of objects of the kind referred to in Section 75 (2) of this Act, or of rights of these, the transferred property or its value may be confiscated from the acquirer if he knew of the connection of the transferred property to the criminal act, or has displayed gross negligence in this respect, or if the transfer to him was gratuitous.

(5) Where a person who is liable to confiscation under Subsections (1)-(4) dies, his liability lapses. This shall not apply to confiscation under Section 75 (1) of this Act.

Section 76a. (I) Total or partial confiscation of property belonging to a person found guilty of a punishable act may take place when

1) the act committed is of a nature which may entail a significant gain; and

2) according to the law, the act committed is punishable by imprisonment of six years of more or it is a violation of the legislation on euphoriants.

(2) Under conditions mentioned in Subsection (1) above, total or partial confiscation of property which the spouse or cohabitant of the offender has acquired may take place unless

1) the property has been acquired more than five years prior to the punishable act upon which the confiscation according to Subsection (1) is based; or

2) the matrimony or cohabitation was not in force at the time of acquisition.

(3) Under conditions mentioned in Subsection (1) above, total or partial confiscation of property transferred to a legal person upon whom the offender, alone or together with his closest relations, has a decisive influence, may take place. The same shall apply if the person in question received a 
significant part of the income of the legal person. Confiscation may not take place if the property was transferred to the legal person more than five years prior to the punishable act upon which confiscation according to Subsection (1) above is based.

(4) Confiscation according to Subsections (1)-(3) above may not take place if the offender renders probable that the property has been acquired in a legal way or with legally acquired means.

(5) In place of confiscation of certain property according to Subsections (1)-(3) above, an amount corresponding to the value of the property or a part of the value, may be confiscated.

Section 77. (1) Where there is confiscation under Section 75 (1) or 76 a of this Act and a person has claim to damages on account of the offence, the confiscated property may be used in satisfaction of the claim of damages.

(2) The same shall apply to objects and amounts confiscated under Section 75 (2) and (3) of this Act, if a decision to this effect is made in the sentence.

(3) Where the offender has, in one of the situations referred to in Subsections (1) and (2) above, paid the injured party compensation according to the sentence, the confiscated sum shall be reduced accordingly.

Section 77a. Where there is reason to believe that objects, which because of their character in connection with other existing circumstances, may be used in a criminal act, they may be confiscated if this measure is regarded as necessary for the prevention of the criminal act. Under the same conditions confiscation of other assets, including money, may take place. Section 75 (4) of this Act shall similarly apply here.

Section 78. (1) A punishable offence shall not involve the suspension of civil rights, including the right to carry on business under an ordinary license or a maritime license.

(2) A person who has been convicted of a punishab1e offence may be debarred from a business requiring a special public authorisation or permission, if the offence committed carries with it an obvious risk of abuse of the position or the occupation concerned.

(3) The question whether the offence committed implies an objection to carrying on a business of the nature referred to in Subsection (2) above shall, at the request of the person whose application for such authorisation or approval has been refused or of any competent authority, be brought before the court by the Prosecuting Authority. Section 59 (2) of this Act shall similarly apply here. The question shall be decided by Court Order. If, according to the decision, the person concerned shall not be allowed to carry on his business, the question may be brought before the court again, but at the earliest after at least two years. Authorisation or permission may also be given by the competent authority before the expiration of this time limit.

Section 79. (1) A person carrying on one of the undertakings referred to in Section 78 (2) of this Act may, on conviction of a punishable offence, be deprived of the right to continue to carry on the business concerned or to carry it on in certain forms if the offence committed carries with it an obvious risk of abuse of the position.

(2) If warranted by special circumstances, the same shall apply to the carrying on of other forms of business. According to the same rule a person can be deprived of his right to be original subscriber to or to be manager or board member of a company with limited liability, or a company or association presupposing a specific public confirmation, or a foundation.

(3) The deprivation of such a right shall be made for a period of not less than one year nor more than five years, as from the date of the final sentence, or indefinitely; in the latter case, the question as to whether the person concerned shall continue to be excluded from carrying on the business may, at the expiration of five years, be brought before the court according to the rules contained in Section 78(3) of this Act. If warranted by special circumstances, the Minister of Justice may permit the case to be brought before the court before the expiration of the time limit of five years referred to in the first 
sentence.

(4) While a case of the kind referred to in Subsections (1) and (2) above is being heard, the court may, by Court Order, debar the person concerned from carrying on the business until the case is finally decided. In its judgment, the court may decide that appeal shall have no suspensory effect.

\section{DANISH ADMINISTRATION OF JUSTICE ACT}

\section{Chapter 73 \\ Search}

Section 793. (1) Pursuant to the rules of this Chapter the police can conduct searches of

1) residences or other dwellings, documents, papers, and similar, as well as the contents of locked objects, and

2) other objects as well as premises other than dwellings.

(2) Searches of premises or objects, which are freely accessible to the police, are not regulated by the rules of this Chapter.

(3) A search to locate a suspect, who is to be arrested, or a person, who is to be taken into custody for the purpose of enforcing a punishment or the alternative penalty in default of payment of a fine, can further take place pursuant to Sections 759 and 761. As for examination of the body of a person and searching the clothes, which the individual is wearing, the rules of Chapter 72 apply. As for examination of letters, telegrams, and similar mail deliveries, the rules of Chapter 71 apply.

Section 794. (1) Searches of dwellings, other premises or objects, of which a suspect has possession, can only be conducted if

1) the individual on reasonable grounds is suspected of an offence, which is indictable by the State, and

2) the search must be presumed to be of significant importance for the investigation.

(2) As for searches of the kinds mentioned in Section 793 (1), no. I, it is further required, either that the case concerns an offence, which under the law can result in imprisonment, or that there are specific reasons to presume that evidence in the case or objects, which can be seized, can be found by the search.

(3) If, during the search of the possessions of a suspect, written messages or similar are found, which originate from a person, who pursuant to the rules of Section 170 is excluded from giving testimony as a witness in the case, searches hereof must not be conducted. The same applies to material, which originates from a person, who is included in Section 172, when the material contains information, which the individual pursuant to Section 172 is exempted from testifying about as a witness in the case.

Section 795. (1) Searches of dwellings, other premises or objects, of which a person, who is not a suspect, has possession, are not regulated by the rules of this Chapter, if the individual grants written consent to the search or if, in connection with the detection or report of an offence, consent is granted by the individual. Besides, a search of the possessions of a person, who is not a suspect, may only take place, if

1) the investigation concerns an offence, which under the law can result in imprisonment, and

2) there are specific reasons to presume that evidence in the case or objects, which can be seized, can be found by the search.

(2) As for the possessions of persons, who pursuant to the rules of Section 170 are excluded from giving testimony as witnesses in the case, written messages and similar between the suspect and the person concerned, as well as notes and similar by this person concerning the suspect, are not subject to search. As for the possessions of persons, who are included in Section 172, material containing information about matters, which the individuals pursuant to Section 172 are exempted from testifying 
about as witnesses in the case, are not subject to search.

Section 796. (I) Decision of search concerning the objects or premises mentioned in Section 793 (1) no. 2, of which a suspect has possession, is made by the police.

(2) Decision of search in other situations is made by court order, cf., however, Subsections (5) and

(6). The court order shall state the specific circumstances in the case upon which it is based, that the conditions for the measure are fulfilled. The court order can at any time be reversed.

(3) If the purpose of the measure would be forfeited if a court order were to be awaited, the police can make the decision to conduct the search. If the person, who has possession of the dwellings, premises or objects, against which the search is directed, puts forward a request hereof, the police shall as soon as possible, and at the latest within 24 hours, bring the case before the court, which in the form of a court order decides if the measure can be approved.

(4) Before the court makes a decision pursuant to Subsection (3), $2^{\text {nd }}$ period, the person who has possession of the dwellings, premises or objects, against which the search is directed, shall be given the opportunity to make a statement. Section 748 (5) and (6) similarly apply.

(5) If the search is directed against dwellings, premises or objects, of which a suspect has possession, and this individual grants a written consent to the search being conducted, the decision of search can also be made by the police.

(6) A decision to the effect that, in connection with the detection or report of an offence, a search of the scene of the crime is to be conducted, can, regardless of the rule in Subsection (2), also be made by the police if the person, who has possession of the dwelling, premise or object concerned, is not a suspect and it is not possible to come into contact with this individual immediately. In that case, notification of the search shall be given to the individual as soon as possible.

Section 797. (I) A search must not be conducted if, considering the purpose of the measure, the significance of the case, and the offence and inconvenience, which the measure can be presumed to cause, it would be a disproportional measure.

(2) In making the decision pursuant to Subsection (1) it shall further be taken into consideration if the search involves destruction or damage of objects.

Section 798. (I) Searches shall be conducted with the utmost leniency as allowed under the circumstances, including, to the extent possible, without causing destruction or damage, and without the measure, due to the time or the way in which it is conducted, giving cause to unnecessary attention.

(2) If the person, who has possession of the dwelling, the premise or the object, or in his absence other persons are encountered, these individuals shall be informed of the conduction of the search and the grounds therefore as well as be invited to witness the search. If the search is conducted based on a court order, this shall, upon request, be shown. If the search is conducted pursuant to the rule in Section 796 (3), the police shall advise the individual of the access to bring the matter before the court. The person, who has possession of the dwelling, the premise or the object, can demand that another person of his choice witnesses the search unless time-based or investigative reasons speak against this. If the purpose of the search requires it, including if obstacles are put in the way of the conduction of the search, the police can decide that the persons encountered shall be removed while the search is taking place.

(3) If nobody is encountered when a search as described in Section 793 (1), no. 1, is to be conducted, two housemates or other witnesses shall, to the extent possible, be summoned to witness the search. After the conduction of a search as described in Section 793 (1), no. 1, the person who has possession of the dwelling or the object shall be notified hereof, and, if the search has been conducted pursuant to the rule in Section 796 (3), of the access to have the matter brought before the court; a possible manner is for the police to leave a notice in writing at the location. 
Section 799. (1) If it is of crucial importance for the investigation that the search is conducted without the knowledge of the suspect or others, the court can, if the investigation concerns an intentional violation of the Criminal Code Chapter 12 or 13 or a violation of the Criminal Code Section 180, Section 183 (1) and (2), Section 183a, Section 186 (1), Section 187 (1) and Sections 191, 192a or 237, in the form of a court order make a decision to this effect and of deviating from the rules of Section 798 (2), $1^{\text {st }}-4^{\text {th }}$ period, and Subsection (3). However, this does not apply as for searches of dwellings, other premises or objects in possession of somebody, who pursuant to the rules of Section 170 is excluded from, or who, pursuant to the rules of Section 172, is exempted from testifying as a witness in the case.

(2) The rules in Section 783 (2) and (3), Section 784, Section 785, and Section 788 apply to the cases described in Subsection (1), $1^{\text {st }}$ period.

(3) The court may decide that repeated searches may be carried out within the time period which according to Subsection (2) is laid down under Section 783 (2). The court shall in this connection fix the number of searches. Under special circumstances the court may decide that an indeterminate number of searches may be carried out.

Section 800. (1) If, during a search, the police obtain information about an offence, which has not formed and which according to the rules of Section 794 (1) no. 1 and (2); Section 795 (1) no. 1; or Section 799 (1), respectively, could not form the basis for the measure, the police can use this information as part of the investigation of the criminal offence concerned, but not as evidence in court in regard to the offence.

(2) The court can decide that Subsection 1 does not apply as for information obtained by the police during a search conducted pursuant to Section 799 (1), if

1) other investigative measures will not be suitable for securing evidence in the case,

2) the case concerns an offence, which under the law can result in imprisonment for six years or more, and

3) the court otherwise finds that it does not cause concern.

\section{Chapter 74}

Seizure and disclosure

Section 801. (1) Pursuant to the rules of this Chapter seizure can take place

1) to secure evidence

2) to secure the claim of the State for costs, confiscation and fine

3 ) to secure the claim of the victim for restoration or compensation, and

4) when the defendant has absconded from further prosecution of the case.

(2) Objects, which the police take into custody, of which nobody has or admits possession, and over which nobody claims a right, are not regulated by the rules of this Chapter.

(3) As for the surrender of letters, telegrams, and similar mail deliveries, as well as for information about connections between telephones, etc., the rules of Chapter 71 apply. As for the removal of objects and money in relation to arrest, the rule of Section 758 (1) further applies.

Section 802. (1) Any object at the disposal of a suspect may be seized, if

1) the person in question is reasonably suspected of an offence liable to public prosecution, and

2) there is reason to presume that the object may serve as evidence or should be confiscated or forfeited, but cf. Subsection (2) below, or that, through the offence, it has been swindled out of somebody who can claim it back.

(2) Goods owned by a suspect may be seized, if 
1) the person in question is reasonably suspected of an offence liable to public prosecution, and

2) seizure is considered necessary to secure any claim of public authorities for costs, any claim for confiscation or forfeiture pursuant to Section 75 (1), first sentence, second limb, and second sentence, Section 75 (3), Section 76a (5) and Section 77 a, second sentence, and any claim for fines or the innocent party's claim for damages in the case.

(3) A suspect's entire property or part thereof, including any property acquired subsequently by the suspect, can be seized if -

1) a charge has been made for an offence for which the potential statutory penalty is imprisonment for one year and six months or more, and

2) the accused has evaded further prosecution in the case.

(4) Notices in writing or the like, originating from a person who is precluded pursuant to the rules of Section 170 from giving evidence as a witness in the case cannot be seized from a suspect. The same applies to material originating from a person falling within the scope of Section 172 when the material contains information concerning which the person is exempted from giving evidence as a witness in the case pursuant to Section 172.

Section 803. (1) Objects at the disposal of a non-suspect can be seized as part of the investigation of an offence liable to public prosecution if it can reasonably be presumed that the object can serve as evidence, should be confiscated or forfeited or, through the offence, has been swindled out of somebody who can claim it back. Other assets, such as money, at the disposal of a non-suspect can be seized as part of the investigation of an offence liable to public prosecution if it can reasonably be presumed that such assets should be confiscated or forfeited. Section 189 applies correspondingly. (2) Notices in writing between the suspect and any person who is precluded pursuant to Section 170 from giving evidence as a witness in the case and such person's notes and the like concerning the suspect cannot be the subject of seizure from such person. Material containing information on matters concerning which any person who falls within Section 172 is exempt from giving evidence as a witness pursuant to Section 172 cannot be the subject of seizure from such person.

Section 804. (1) As part of the investigation of an offence, which is indictable by the State, a person who is not a suspect can be ordered to produce or surrender objects (disclosure), if there is reason to presume that an object, of which the individual has possession, can serve as evidence, should be confiscated or by the offence has been purloined from somebody who can claim it back.

(2) If an object has been surrendered to the police following an order of disclosure, the rules of seizure pursuant to Section 803 (1) similarly apply.

(3) If an object, without an order to this effect, has been handed over to the police due to the reasons mentioned in Subsection (1), then Section 807 (5) applies. If a request of return is made, and the police do not grant the request, the police shall as soon as possible, and at the latest within 24 hours, bring the case before the court with a petition for seizure. In this case Section $806(3), 2^{\text {nd }}$ period, and (5), $1^{\text {st }}$ period, apply.

(4) An order of disclosure cannot be issued if it will produce information about matters, which the individual would be excluded or exempted from testifying about as a witness pursuant to Sections 169-172.

(5) The Minister of Justice can issue rules about financial compensation in special cases or costs relating to fulfilment of orders of disclosure.

Section 805. (1) Seizure must not take place, and orders of disclosure must not be issued, if the measure is disproportional considering the significance of the case, and the loss or the inconvenience, which the measure can be presumed to cause.

(2) If the purpose of the measure can be attained by less invasive measures, including by posing a collateral, a written agreement to this effect can be made with the individual against whom the measure is directed. 
(3) As for seizure as a security for the c1aim of the State for costs, claim for confiscation pursuant to the Criminal Code Section 75 (1), $1^{\text {st }}$ period, $2^{\text {nd }}$ part, and $2^{\text {nd }}$ period, and (3), Section 76a (5), and Section $77 a, 2^{\text {nd }}$ period, claims for fines or the claim of the victim for compensation, the rules of Sections 509-516 similarly apply.

Section 806. (1) Decision about seizure and orders of disclosure are made upon request of the police. Request of seizure to secure a claim for compensation can be made by the victim as well. (2) The decision is made by the court in the form of an order, cf., however, Subsection (7). The court order shall state the specific circumstances in the case upon which it is based, that the conditions for the measure are fulfilled. The court order can at any time be reversed.

(3) If the purpose of the measure would be forfeited if a court order were to be awaited, the police can make the decision about seizure, cf., however, Subsection (4). Upon request from the individual, against whom the measure is directed, the police shall as soon as possible, and at the latest within 24 hours, bring the case before the court, which in the form of an order decides if the measure can be approved.

(4) Seizure pursuant to Section 802 (3) can only take place according to a court order. The same applies to seizure of printed works or sound or picture programmes included under the Law of Media Responsibility, which contents causes for responsibility to be imposed.

(5) Before the court makes a decision pursuant to Subsection (3), $2^{\text {nd }}$ period, the person against whom the measure is directed shall have had the opportunity to make a statement. Section $748(5)$ and (6) similarly apply.

(6) Before the court makes a decision about disclosure pursuant to Section 804, the person, who has possession of the object, shall have had the opportunity to make a statement. Section 748 (5) and (6) 6 similarly apply. The rule of the $1^{\text {st }}$ period does not apply if the decision of the court is intended as the basis for an international request of disclosure.

(7) Decision of seizure is made by the police if the person, against whom the measure is directed, grants a written consent to the measure.

Section 807. (1) The police carry out seizures. If seizure takes place based on a court order, this order shall, upon request, be shown to the person, against whom the measure is directed. If seizure takes place pursuant to the rule of Section 806 (3) the police shall advise the individual of the access to have the matter brought before the court .

(2) The police ensure, by contacting the person against whom the measure is directed, that an order of disclosure is complied with. The order of the court shall, upon request, be shown to the individual. If, without valid excuse, the individual refuses to comply with the order, the rule of Section 178 similarly applies.

(3) If material is seized from persons, who are included in Section 172, the individual can demand that the first examination of the material be done by the court. Section $806(5), 1^{\text {st }}$ period, similarly applies as for the examination by the court. Until the first examination can take place the material is kept by the police.

(4) If the court has issued an order about seizure of all or a part of a property, pursuant to Section 802 (3), the police shall provide for the appointment of a guardian to administrate the seized property. The police shall register the court order about seizure according to the rules of the Law of Registration Section 48. The court order is served the defendant according to the rules in Section 159.

(5) Objects, which come into police custody as a result of seizure or orders to surrender, shall as soon as possible be recorded and marked. The police shall, upon request, issue a receipt for the reception. 